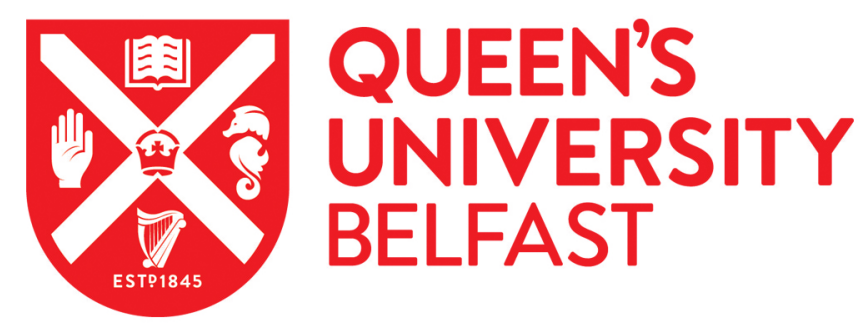

\title{
Mendelian Randomisation Study of Smoking, Alcohol, and Coffee Drinking in Relation to Parkinson's Disease
}

Comprehensive Unbiaised Risk Factor Assessment for Genetics and Environment in Parkinson's Disease (COURAGE-PD) consortium (2021). Mendelian Randomisation Study of Smoking, Alcohol, and Coffee Drinking in Relation to Parkinson's Disease. Journal of Parkinson's disease. https://doi.org/10.3233/JPD-212851

Published in:

Journal of Parkinson's disease

Document Version:

Peer reviewed version

Queen's University Belfast - Research Portal:

Link to publication record in Queen's University Belfast Research Portal

\section{Publisher rights}

Copyright 2021, the Authors.

This work is made available online in accordance with the publisher's policies. Please refer to any applicable terms of use of the publisher.

\section{General rights}

Copyright for the publications made accessible via the Queen's University Belfast Research Portal is retained by the author(s) and / or other copyright owners and it is a condition of accessing these publications that users recognise and abide by the legal requirements associated with these rights.

Take down policy

The Research Portal is Queen's institutional repository that provides access to Queen's research output. Every effort has been made to ensure that content in the Research Portal does not infringe any person's rights, or applicable UK laws. If you discover content in the Research Portal that you believe breaches copyright or violates any law, please contact openaccess@qub.ac.uk. 


\section{Mendelian randomisation study of smoking, alcohol, and coffee drinking in relation to Parkinson's disease}

Cloé Domenighettia, Pierre-Emmanuel Sugiera, Ashwin Ashok Kumar Sreelatha ${ }^{b}$, Claudia Schultec,d, Sandeep Grover ${ }^{b}$, Océane Mohamed ${ }^{a}$, Berta Portugala, Patrick Maye, Dheeraj R. Bobbilie,f, Milena Radivojkov-Blagojevic ${ }^{g}$, Peter Lichtnerg, Andrew B. Singleton ${ }^{\mathrm{h}, \mathrm{l}}$, Dena G. Hernandez ${ }^{\mathrm{h}}$, Connor Edsall ${ }^{\mathrm{h}}$, George D. Mellickj, Alexander Zimprichk, Walter Pirker', Ekaterina Rogaevam ${ }^{\mathrm{m}}$, Anthony E. Lang ${ }^{\mathrm{n}, \mathrm{op}}$, Sulev Koks ${ }^{q, r}$, Pille Taba ${ }^{\mathrm{s}, \mathrm{t}}$, Suzanne Lesage ${ }^{\mathrm{u}}$, Alexis Brice ${ }^{\mathrm{u}}$, Jean-Christophe Corvolu,v, Marie-Christine Chartier-Harlinw, Eugénie Mutezww, Kathrin Brockmannn ${ }^{c, d}$, Angela B. Deutschländerr,y,z, Georges M. Hadjigeorgiouaa,ab, Efthimos Dardiotisaa, Leonidas Stefanis ${ }^{a c, a d}$, Athina Maria Simitsiac, Enza Maria

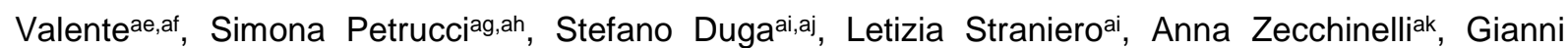
Pezzoliak, Laura Brighina ${ }^{a l, a m}$, Carlo Ferrarese ${ }^{a l, a m}$, Grazia Annesian, Andrea Quattrone ${ }^{\text {ao }}$, Monica Gagliardiap, Hirotaka Matsuoaq, Yusuke Kawamuraaq, Nobutaka Hattoriar, Kenya Nishioka ${ }^{\text {ar }}$, Sun Ju Chungas, Yun Joong Kim ${ }^{\text {at }}$, Pierre Kolber ${ }^{\text {au }}$, Bart PC van de Warrenburgav, Bastiaan R. Bloem ${ }^{\text {av }}$, Jan Aaslyaw, Mathias Toftax, Lasse Pihlstrømax, Leonor Correia Guedes ay,az, Joaquim J. Ferreiraay,ba, Soraya Bardien $^{\mathrm{bb}}$, Jonathan Carrbc, Eduardo Tolosa ${ }^{\mathrm{bd}, \mathrm{be}}$, Mario Ezquerra ${ }^{\mathrm{bf}}$, Pau Pastorbg,bh, Monica DiezFairen bg,bh, Karin Wirdefeldtti,bj, Nancy L. Pedersen ${ }^{\mathrm{bj}}$, Caroline Ran ${ }^{\mathrm{bk}}$, Andrea C. Belin ${ }^{\mathrm{bk}}$, Andreas Puschmann $^{\text {bl }}$, Clara Hellberg ${ }^{\text {bl }}$, Carl E. Clarke ${ }^{\text {bm }}$, Karen E. Morrison ${ }^{\text {bn }}$, Manuela Tan ${ }^{\text {bo }}$, Dimitri Krainc ${ }^{\text {bp }}$, Lena F. Burbullabp, Matt J. Farrerba, Rejko Krügerau,br,bs, Thomas Gasser ${ }^{c, d}$, Manu Sharma $a^{b, c}$, Alexis Elbaz $^{\mathrm{a}}$ on behalf of the Comprehensive Unbiaised Risk Factor Assessment for Genetics and Environment in Parkinson's Disease (COURAGE-PD) consortium. 


\section{Affiliations}

a Université Paris-Saclay, UVSQ, Univ. Paris-Sud, Inserm, Team "Exposome, heredity, cancer and health", CESP, 94807, Villejuif, France.

${ }^{\mathrm{b}}$ Centre for Genetic Epidemiology, Institute for Clinical Epidemiology and Applied Biometry, University of Tubingen, Germany.

${ }^{\mathrm{C}}$ Department for Neurodegenerative Diseases, Hertie Institute for Clinical Brain Research, University of Tubingen, Germany.

${ }^{d}$ German Center for Neurodegenerative Diseases (DZNE), Tubingen, Germany.

e Translational Neuroscience, Luxembourg Centre for Systems Biomedicine (LCSB), University of Luxembourg, Esch-Belval, Luxembourg.

${ }^{f}$ MeGeno S.A, Esch-sur-Alzette, Luxembourg.

${ }^{\mathrm{g}}$ Institute of Human Genetics, Helmholtz Zentrum München, Neuherberg, Germany.

${ }^{\text {h }}$ Molecular Genetics Section, Laboratory of Neurogenetics, NIA, NIH, Bethesda, MD 20892, USA.

' Center For Alzheimer's and Related Dementias, NIA, NIH, Bethesda, MD 20892, USA.

j Griffith Institute for Drug Discovery, Griffith University, Don Young Road, Nathan, Queensland, Australia.

${ }^{k}$ Department of Neurology, Medical University of Vienna, Austria.

' Department of Neurology, Wilhelminenspital, Austria.

m Tanz Centre for Research in Neurodegenerative Diseases, University of Toronto, Toronto, Ontario, Canada.

${ }^{\mathrm{n}}$ Edmond J. Safra Program in Parkinson's Disease, Morton and Gloria Shulman Movement Disorders

Clinic, Toronto Western Hospital, UHN, Toronto, Ontario, Canada.

- Division of Neurology, University of Toronto, Toronto, Ontario, Canada.

${ }^{\mathrm{p}}$ Krembil Brain Institute, Toronto, Ontario, Canada.

${ }^{\mathrm{a}}$ Centre for Molecular Medicine and Innovative Therapeutics, Murdoch University, Murdoch, Australia.

${ }^{r}$ Perron Institute for Neurological and Translational Science, Nedlands, Western Australia, Australia.

${ }^{\mathrm{s}}$ Department of Neurology and Neurosurgery, University of Tartu, Estonia.

${ }^{\mathrm{t}}$ Neurology Clinic, Tartu University Hospital, Tartu, Estonia.

"Sorbonne Université, Institut du Cerveau - Paris Brain Institute - ICM, INSERM, CNRS, Assistance

Publique Hôpitaux de Paris, Department of Neurologie, Paris, France.

${ }^{v}$ Assistance Publique Hôpitaux de Paris, Department of Neurology, CIC Neurosciences, Paris, France.

w Univ. Lille, Inserm, CHU Lille, UMR-S 1172 - LilNCog- Centre de Recherche Lille Neurosciences \& Cognition, F-59000 Lille, France.

${ }^{x}$ Department of Neurology, Ludwig Maximilians University of Munich, Germany.

${ }^{\vee}$ Department of Neurology, Max Planck Institute of Psychiatry, Munich, Germany.

${ }^{z}$ Department of Neurology and Department of Clinical Genomics, Mayo Clinic Florida, Jacksonville, FL, USA.

aa Department of Neurology, Laboratory of Neurogenetics, University of Thessaly, University Hospital of Larissa, Larissa, Greece.

${ }^{a b}$ Department of Neurology, Medical School, University of Cyprus, Nicosia, Cyprus.

ac 1 st Department of Neurology, Eginition Hospital, Medical School, National and Kapodistrian University of Athens, Athens, Greece.

${ }^{\text {ad }}$ Center of Clinical Research, Experimental Surgery and Translational Research, Biomedical Research Foundation of the Academy of Athens, Athens, Greece.

ae Department of Molecular Medicine, University of Pavia, Pavia, Italy.

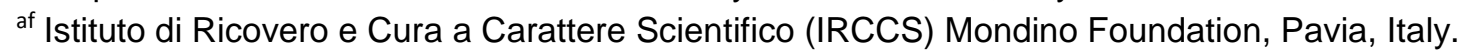

as UOC Medical Genetics and Advanced Cell Diagnostics, S. Andrea University Hospital, Rome, Italy.

ah Department of Clinical and Molecular Medicine, University of Rome, Rome, Italy.

ai Department of Biomedical Sciences - Humanitas University, Milan, Italy.

aj Humanitas Clinical and Research Center, IRCCS, Via Manzoni 56, 20089 Rozzano, Milan, Italy.

ak Parkinson Institute, Azienda Socio Sanitaria Territoriale (ASST) Gaetano Pini/CTO, Milano.

al Department of Neurology, San Gerardo Hospital, Monza, Italy. 
am Department of Medicine and Surgery and Milan Center for Neuroscience, University of Milano Bicocca, Milano, Italy.

an Institute for Biomedical Research and Innovation, National Research Council, Cosenza, Italy.

ao Institute of Neurology, Magna Graecia University, Catanzaro, Italy.

${ }^{a p}$ Institute of Molecular Bioimaging and Physiology National Research Council, Catanzaro, Italy.

aq Department of Integrative Physiology and Bio-Nano Medicine, National Defense Medical College, Saitama 359-8513, Japan.

${ }^{\text {ar }}$ Department of Neurology, Juntendo University School of Medicine, Bunkyo-ku, Tokyo 113-8421, Japan.

as Department of Neurology, Asan Medical Center, University of Ulsan College of Medicine, Seoul, South Korea.

at Department of Neurology, Yonsei University College of Medicine, Seoul, South Korea.

au Neurology, Centre Hospitalier de Luxembourg, Luxembourg, Luxembourg.

${ }^{\text {av }}$ Radboud University Medical Centre, Donders Institute for Brain, Cognition and Behaviour, Department of Neurology, Nijmegen, The Netherlands.

${ }^{a w}$ Department of Neurology, St Olav's Hospital and Norwegian University of Science and Technology, Trondheim.

${ }^{\text {ax }}$ Department of Neurology, Oslo University Hospital, Oslo, Norway.

ay Instituto de Medicina Molecular João Lobo Antunes, Faculdade de Medicina, Universidade de Lisboa, Lisbon, Portugal.

az Department of Neurosciences and Mental Health, Neurology, Hospital de Santa Maria, Centro Hospitalar Universitario Lisboa Norte (CHULN), Lisbon, Portugal.

ba Laboratory of Clinical Pharmacology and Therapeutics, Faculdade de Medicina, Universidade de Lisboa, Lisbon, Portugal.

bb Division of Molecular Biology and Human Genetics, Department of Biomedical Sciences, Faculty of Medicine and Health Sciences, Stellenbosch University, South Africa.

bc Division of Neurology, Department of Medicine, Faculty of Medicine and Health Sciences, Stellenbosch University, South Africa.

bd Parkinson's disease \& Movement Disorders Unit, Neurology Service, Hospital Clínic de Barcelona, Institut d'Investigacions Biomèdiques August Pi i Sunyer (IDIBAPS), University of Barcelona, Barcelona, Spain

be Centro de Investigación Biomédica en Red sobre Enfermedades Neurodegenerativas (CIBERNED: CB06/05/0018-ISCIII) Barcelona, Spain.

bf Lab of Parkinson Disease and Other Neurodegenerative Movement Disorders, Institut d'Investigacions Biomèdiques August Pi i Sunyer (IDIBAPS), Institut de Neurociències, Universitat de Barcelona, ES-08036 Barcelona, Catalonia.

bg Fundació per la Recerca Biomèdica i Social Mútua Terrassa, Terrassa, Barcelona, Spain.

bh Movement Disorders Unit, Department of Neurology, Hospital Universitari Mutua de Terrassa, Terrassa, Barcelona, Spain.

bi Department of Clinical Neuroscience, Karolinska Institutet, Stockholm, Sweden.

bj Department of Medical Epidemiology and Biostatistics, Karolinska Institutet, Stockholm, Sweden

bk Department of Neuroscience, Karolinska Institutet, Stockholm, Sweden.

bl Lund University, Skåne University Hospital, Department of Clinical Sciences Lund, Neurology, Getingevägen 4, 221 85, Lund, Sweden.

$\mathrm{bm}$ University of Birmingham and Sandwell and West Birmingham Hospitals NHS Trust, United Kingdom.

bn Faculty of Medicine, Health and Life Sciences, Queens University, Belfast, United Kingdom.

bo Department of Clinical and Movement Neurosciences, UCL Queen Square Institute of Neurology, University College London, London, UK.

bp Department of Neurology, Northwestern University Feinberg School of Medicine, Chicago, Illinois 60611, United States.

${ }^{\mathrm{bq}}$ Department of Neurology, McKnight Brain Institute, University of Florida, Gainesville, FL, USA.

${ }^{\text {br }}$ Parkinson's Research Clinic, Centre Hospitalier de Luxembourg, Luxembourg.

bs Transversal Translational Medicine, Luxembourg Institute of Health (LIH), Strassen, Luxembourg. 
Corresponding author: Alexis Elbaz, INSERM U1018 CESP, Hôpital Paul Brousse, Bâtiment 15/16, 16 avenue Paul Vaillant Couturier, 94807 Villejuif Cedex, France. Phone number: +33145595370 . Email: alexis.elbaz@inserm.fr

Running title: MR study of smoking, alcohol, and coffee in PD

Character count, title: 105

Character count, running head: 46

Word count of abstract: 250

Total word count of text: 3942

Number of references: 50

Number of tables: 4

Number of figures: 1

Supplementary material: supplementary methods, supplementary references, 8 tables, 3 figures. 


\section{Abstract}

Background: Previous studies showed that lifestyle behaviors (cigarette smoking, alcohol, coffee) are inversely associated with Parkinson's disease (PD). The prodromal phase of PD raises the possibility that these associations may be explained by reverse causation.

Objective: To examine associations of lifestyle behaviors with PD using two-sample Mendelian randomisation (MR) and the potential for survival and incidence-prevalence biases.

Methods: We used summary statistics from publicly available studies to estimate the association of genetic polymorphisms with lifestyle behaviors, and from Courage-PD $(7,369$ cases, 7,018 controls; European ancestry) to estimate the association of these variants with PD. We used the inverse-variance weighted method to compute odds ratios (ORIVW) of PD and 95\% confidence intervals $(\mathrm{Cl})$. Significance was determined using a Bonferroni-corrected significance threshold $(p=0.017)$.

Results: We found a significant inverse association between smoking initiation and PD (OR per 1 -SD increase in the prevalence of ever smoking $=0.74,95 \% \mathrm{Cl}=0.60-0.93, \mathrm{p}=0.009$ ) without significant directional pleiotropy. Associations in participants $\leq 67 y$ and cases with disease duration $\leq 7 y$ were of a similar size. No significant associations were observed for alcohol and coffee drinking. In reverse MR, genetic liability toward PD was not associated with smoking or coffee drinking, but was positively associated with alcohol drinking.

Conclusion: Our findings are in favor of an inverse association between smoking and PD that is not explained by reverse causation, confounding, and survival or incidence-prevalence biases. Genetic liability toward PD was positively associated with alcohol drinking. Conclusions on the association of alcohol and coffee drinking with PD are hampered by insufficient statistical power.

Keywords: Smoking, alcohol, coffee, Parkinson's disease, Mendelian randomisation. 


\section{Introduction}

PD is considered as a multifactorial disease, involving genetic susceptibility and environmental factors.[1] Epidemiologic studies have revealed a striking pattern, whereby several lifestyle behaviours, including cigarette smoking, alcohol, and coffee drinking, are inversely associated with PD.[2] It remains debated whether these inverse associations are causal. The existence of a long prodromal phase in $\mathrm{PD}[3,4]$ raises the possibility that they may be explained by reverse causation defined as situations where the outcome precedes and influences the exposure. For instance, the prodromal phase of PD may be characterized by a loss of appetence for cigarettes,[5] and patients who later develop PD may be more successful in their attempts to quit smoking during the prodromal phase due to reduced dopamine reward.[6]

Mendelian randomisation (MR) is a form of instrumental variable analysis that uses genetic variants associated with an exposure as instruments to estimate its causal association with a disease.[7] Unlike traditional epidemiologic approaches, MR analyses are not biased by confounding or reverse causation if a set of assumptions are met.[8] However, MR analyses in elderly populations may be biased due to survival bias, a form of selection bias that may arise as older persons consist of a non-random subset of the general population who have survived long enough to be included into the study.[9] This bias is a particular threat for MR studies investigating exposures that strongly affect survival,[10] and is more pronounced for two-sample than one-sample MR studies.[9] MR studies that include prevalent cases may also be biased by incidence-prevalence bias, if the genetic instrument is associated with survival after disease onset.[11]

As part of the COmprehensive Unbiased Risk factor Assessment for Genetics and Environment in PD (Courage-PD) consortium, we used two-sample MR to examine the association of three lifestyle behaviours (smoking, alcohol drinking, coffee drinking) with PD, and assessed whether MR findings are robust in analyses addressing the potential for survival and incidence-prevalence biases. 


\section{Material and methods}

\section{Study design: two-sample Mendelian randomisation}

MR uses genetic variants, mainly single nucleotide polymorphisms (SNPs), associated with an exposure to estimate its causal effect on an outcome. For SNPs to be valid instruments, three assumptions must be verified: (I) SNPs should be associated with the exposure (IV1 assumption); (ii) SNPs should not be directly associated with the outcome except through the exposure (IV2 assumption); (iii) SNPs should not be associated with unmeasured confounders of the exposure-outcome association (i.e., no horizontal pleiotropy, IV3 assumption).[7]

In two-sample MR, summary statistics (effect size estimates and standard errors [SE]) for the SNP-exposure and SNP-outcome associations, required to estimate the causal exposure-disease association, come from two independent samples.

\section{PD GWAS: Courage-PD consortium}

We used summary statistics from a GWAS (NeuroChip)[12] in 23 out of 35 studies from the Courage-PD consortium (Supplementary methods). We excluded from the analyses: samples overlapping with the international Parkinson Disease Genomics Consortium (iPDGC); Asian studies (so that estimates for SNP-exposure and SNP-PD associations come from Caucasian populations); studies that included cases only; studies with less than 50 cases and 50 controls. As the role of environmental factors may be different in carriers of Mendelian PD mutations, we also excluded participants with GBA/LRRK2 mutations or with positive family history of PD. Participants' characteristics are shown in Supplementary table 1.

In each study, the frequency of SNPs was compared in cases and controls under an additive model using logistic regression adjusted for sex and the first four principal components. We meta-analysed summary statistics from the 23 GWAS (European ancestry: 7,369 cases, 7,018 controls) using a fixed $\left(I^{2} \leq 25 \%\right)$ or random $\left(I^{2}>25 \%\right)$ effects model (Supplementary methods). 
Individual studies within each genome-wide association study had received approval from a relevant institutional review board from their country, and informed consent was obtained from participants or from a caregiver, legal guardian, or other proxy.

\section{GWAS of exposures}

We used summary statistics (betas, SEs) from published GWAS in individuals of European descent to select SNPs associated with exposures of interest at a genome-wide significant threshold $\left(p<5 \times 10^{-8}\right)$ and with a minor allele frequency $(M A F) \geq 0.01$. To retain independent SNPs, we clumped them based on European ancestry reference data (1000 Genomes Project, $r^{2}>0.001$, genomic region $=10,000 \mathrm{~kb}$ ). For SNPs not available in Courage-PD, we selected proxies in high linkage disequilibrium (LD) with the index SNP $\left(r^{2}>0.8\right)$ according to LDlink[13] or SNIPA.[14] Summary statistics were harmonised on alleles positively associated with exposures. Ambiguous palindromic SNPs $(A / T, C / G)$ with a MAF>0.42 were discarded.[15]

Smoking initiation and alcohol drinking: the GWAS and Sequencing Consortium of Alcohol and Nicotine use (GSCAN) provided summary statistics for smoking initiation ( $n=1,232,091,203$ SNPs) and for the number of alcohol drinks per week ( $n=941,280,71$ SNPs) in participants of European descent.[16] The proxy $r s 117495226$ in high LD $\left(r^{2}=0.90\right)$ with the index SNP rs6050446 was used.

Information on smoking status was missing in several studies from Courage-PD; therefore, we were not able to run analyses stratified by smoking status and to examine the role of SNPs associated with smoking heaviness or age at smoking cessation or initiation in smokers.[17] To overcome this limitation, we used a lifetime smoking exposure index developed using UK Biobank data (in 462,690 European descent) that allows to perform MR using summary data from samples unstratified by smoking status. Briefly, this lifetime smoking index combines several aspects of smoking, including smoking status and, among ever smokers, duration, heaviness, and cessation, and was validated using positive outcomes (e.g., lung cancer). We selected 126 SNPs associated with this index.[17] 
Coffee drinking: we used a GWAS on self-reported bitter and sweet beverage consumption, including coffee (European ancestry, $n=370,000,11$ SNPs).[18]

\section{Statistical analyses}

Statistical analyses were performed using the TwoSampleMR, MRPRESSO, and simex $\mathrm{R}$ packages (R Foundation for Statistical Computing, Vienna, Austria). P-values are two-sided. We examined three main exposures (smoking initiation, alcohol drinking, coffee drinking). To account for multiple testing, we used a conservative approach and applied a Bonferroni corrected significance level of 0.017 (i.e., $0.05 / 3$ ). P-values $\leq 0.05$ but $>0.017$ were considered as suggestive statistical evidence for an association.[19]

Only SNPs available in $75 \%(n=17)$ of the studies or more were retained for our analyses. For each SNP, we computed the proportion of the variance of the exposure explained by the SNP $\left(\mathrm{R}^{2}\right) \cdot[8]$

For MR analyses of individual SNPs, we used the Wald ratio estimate (exponentiated ratio of the SNP-outcome association to the SNP-exposure association).

Our primary MR analyses based on multiple SNPs were conducted using the randomeffects inverse-variance weighted (IVW) method that provides accurate estimates for SNPs that verify IV assumptions. Heterogeneity between genetic instruments was tested using the Cochran's Q-statistic.[7]

In sensitivity MR analyses, we used other approaches that relax some IV assumptions. The MR-Egger method can detect directional pleiotropy and provides corrected effect estimates but has low power and requires the InSIDE (INstrument Strength Independent of Direct Effect) assumption.[20] We used the $\mathrm{I}^{2} \mathrm{GX}$ statistic to quantify the strength of regression dilution bias in SNP-exposure association estimates, with values $<90 \%$ indicating violation of the NOME (No Measurement Error) assumption, in which case we used the SIMEX method to correct MR-Egger estimates.[21] The weighted median-method provides consistent estimates if at least $50 \%$ of the SNPs are valid instruments.[22] The weighted mode-based method uses the causal estimate from each SNP to calculate the modal estimate. The largest group of 
variants with the same causal estimate in the asymptotic limit are considered valid instruments.[23] MR-PRESSO allows to detect outliers (global test), to compute an estimate corrected for horizontal pleiotropy after removing them (if $p$-global test $<0.05$ ), and to test the difference between the original and updated estimates (distortion test).[24] In addition, as two SNPs were associated with both alcohol and coffee drinking, we repeated analyses for these phenotypes after excluding them.

PD is typically a disease of old age, and survival bias may bias genetic associations and MR estimates in any direction in studies in older populations for exposures that are associated with survival into old age (Supplementary figure 1).[9, 10] In some situations, increasing age is associated with increasing bias; in addition, bias is likely to be more pronounced in two-sample than one-sample MR studies. As smoking and alcohol drinking are strongly associated with survival, we performed analyses stratified by median age at study of cases and controls (67 years) and examined whether MR estimates observed overall were consistent with those seen in younger participants in whom survival bias is unlikely as mortality rates are low in this group.[25-27]

The consortium included prevalent and incident patients. If genetic variants have a stronger effect on survival in PD patients than controls, genetic associations may be biased.[11] We examined whether MR estimates in cases with shorter disease duration (median $\leq 7$ years) compared to controls were consistent with those obtained overall.

Finally, we tested for reverse causation by performing a reverse MR analysis where the exposure was PD genetic susceptibility and the outcome was smoking initiation, alcohol, or coffee drinking. We identified top SNPs (and corresponding association estimates) from the largest PD iPDGC GWAS as exposure instrumental variables,[28] and extracted summary statistics for these SNPs from the GWAS for lifestyle behaviours [16-18]. For smoking initiation, we used summary statistics without 23 andMe $(\mathrm{N}=599,289)$. In this analysis, we estimated the effect of genetic liability toward PD on lifestyle behaviours in order to examine whether genetic liability toward PD is associated with smoking initiation, alcohol drinking, or coffee drinking. ORs are scaled to 1-unit increase in log odds of liability to PD.[29] 


\section{Statistical power}

For each exposure, we computed the proportion of variance explained by the SNPs, the Fstatistic as a measure of instrument strength,[15] and statistical power for a type-I error rate of $5 \%$ and $1.7 \%$ (Supplementary table 2).[30]

\section{Data availability}

Results can be reproduced using Supplementary tables 3 and 4; no additional data available. 


\section{Results}

The associations of SNPs with exposures and PD are shown in Supplementary table 3. Supplementary table 5 shows the number of SNPs retained for each exposure and F-statistics.

\section{Smoking and PD}

Of the SNPs positively associated with smoking traits, two (1.1\%) were positively associated with PD at $p<0.05$ for smoking initiation, and five (4.4\%) for the lifetime smoking index; six (3.3\%) were inversely associated with PD for smoking initiation, and five (4.4\%) for the lifetime smoking index (Supplementary table 3).

Smoking initiation was significantly and inversely associated with $P D\left(O R_{I V w}=0.74,95 \%\right.$ $\mathrm{Cl}=0.60-0.93, \mathrm{p}=0.009 ;$ Table 1, Supplementary figure 2). The weighted median approach also showed a significant inverse association $(\mathrm{p}=0.008)$ while the weighted mode approach yielded slightly lower point estimates with wider Cls. The MR-Egger method did not show significant directional pleiotropy.

In sensitivity analyses, there was a suggestive inverse association for the lifetime smoking index $\left(\mathrm{OR}_{\mathrm{Ivw}}=0.54,95 \% \mathrm{Cl}=0.29-1.00, \mathrm{p}=0.050\right.$; Table 1, Supplementary figure 2) that became more significant after excluding two outliers identified by MR-PRESSO (OR $\mathrm{MR}_{\text {- }}$ PRESSO $=0.51,95 \% \mathrm{Cl}=0.29-0.89, \mathrm{p}=0.021$ ). The weighted median method yielded an inverse association that was statistically significant $(p=0.017)$. MR-Egger did not show significant directional pleiotropy.

Both for smoking initiation and the lifetime smoking index, associations tended to be stronger in younger individuals (smoking initiation: $\mathrm{OR}_{\mathrm{IVW}}=0.68,95 \% \mathrm{Cl}=0.48-0.97$; lifetime smoking index: $\mathrm{OR}_{\mathrm{IVw}}=0.46,95 \% \mathrm{Cl}=0.19-1.09$ ) than in older ones (smoking initiation: $\mathrm{OR}_{\mathrm{IVW}}=0.83,95 \% \mathrm{Cl}=0.58-1.18$; lifetime smoking index: $\mathrm{OR}_{\mathrm{IVW}}=0.88,95 \% \mathrm{Cl}=0.37-2.07$ ) and were consistent with those seen overall (Figure 1, Supplementary table 6). Associations were of a similar size in patients with shorter and longer disease duration and comparable to associations seen overall (Figure 1, Supplementary table 7). 


\section{Alcohol drinking and PD}

Of the SNPs positively associated with alcohol drinking, two (3.2\%) were positively and three (4.8\%) were inversely associated with PD at $p<0.05$ (Supplementary table 3).

There was no significant association between alcohol drinking and PD $\left(O R_{I V w}=0.68\right.$, $95 \% \mathrm{Cl}=0.39-1.18, \mathrm{p}=0.17 ;$ Table 2, Supplementary figure 2). Exclusion of two SNPs associated with coffee drinking led to similar conclusions. In stratified analyses, there was no significant association between alcohol drinking and PD in younger individuals and patients with shorter disease duration (Supplementary tables 6-7). There was a trend towards an inverse association only in prevalent $P D$ cases $\left(\mathrm{OR}_{\mathrm{IVw}}=0.53,95 \% \mathrm{Cl}=0.27-1.02, \mathrm{p}=0.057\right)$.

MR analyses using a single SNP in the $A D H 1 B$ gene (rs1229984) showed no association with $\mathrm{PD}(\mathrm{OR}$ wald ratio $=0.93,95 \% \mathrm{Cl}=0.45-1.91, \mathrm{p}=0.85$; Supplementary table 3$)$; this gene plays an important role in explaining alcohol drinking variance and analyses based on this gene are less likely to be biased by pleiotropy due to the known role of alcohol dehydrogenase in alcohol metabolism.

\section{Coffee drinking and PD}

Of the SNPs positively associated with coffee drinking, one (9.1\%) was positively, and another (9.1\%) was inversely associated with PD at $p<0.05$ (Supplementary table 3).

There was a positive and non-statistically significant association of geneticallypredicted coffee drinking with $\mathrm{PD}\left(\mathrm{OR}_{\mathrm{IVw}}=1.69,95 \% \mathrm{Cl}=0.51-5.63, \mathrm{p}=0.40\right.$; Table 3, Supplementary figure 2). However, after excluding two SNPs associated with alcohol drinking, the association decreased $\left(\mathrm{OR}_{\mathrm{IVW}}=1.09,95 \% \mathrm{Cl}=0.26-4.45, \mathrm{p}=0.91\right)$. Stratified analyses showed no associations (Supplementary tables 6-7).

MR analyses based on SNPs in two genes that are known to play an important role in caffeine metabolism (AHR-rs4410790, CYP1A2-rs2472297) showed no association with PD (rs4410790: OR $\mathrm{R}_{\text {Wald ratio }}=0.79,95 \% \mathrm{Cl}=0.21-2.98, \mathrm{p}=0.72 ; \mathrm{rs} 2472297: \mathrm{R}_{\text {Wald ratio }}=2.09,95 \%$ $\mathrm{Cl}=0.47-9.16, \mathrm{p}=0.33$; Supplementary table 3 ). 


\section{Reverse MR}

Supplementary table 8 shows the SNPs and association estimates used for reverse MR analyses. Table 4 shows the results of reverse MR analyses. There was no association between genetic liability toward PD and smoking or coffee drinking. For alcohol drinking, genetic liability toward PD was positively associated with alcohol drinking using the IVW method. MR-PRESSO identified 5 outliers; the corrected MR estimate after excluding these outliers was still in favour of a positive association. 


\section{Discussion}

Based on data from the Courage-PD consortium and after exclusion of samples overlapping with iPDGC, our findings add further evidence in favour of an inverse association between smoking initiation and PD but not for alcohol and coffee drinking.

\section{Smoking}

According to observational studies, ever smokers have a $\sim 40 \%$ reduced risk of developing PD.[31] It has been argued, however, that this association may be due to reverse causation[5] as PD patients may stop smoking more easily during the PD prodromal phase than other persons due to reduced responsiveness to nicotine.[32] Others argued that the association seen in long-term ex-smokers[1] and the dose-effect relationship seen both in ex- and currentsmokers are not in favour of this hypothesis.[33]

Previous MR studies examined the association between smoking and PD using iPDGC data. One study (9,581 cases, 33,245 controls) assessed several risky behaviours in relation with PD,[34] and reported a significant inverse association for smoking initiation (213 SNPs; OR per log odds of ever smoking $=0.71,95 \% \mathrm{Cl}=0.57-0.90)$. In another study $(37,688$ cases with some overlap with the previous study, 18,618 UK Biobank proxy-cases, 1.4 million controls), there was a trend towards an inverse association between ever-smoking and PD that was not statistically significant (OR per log odds of ever-smoking $=0.94,95 \% \mathrm{Cl}=0.88$ 1.01).[28] Recently, another MR study used the same dataset to assess the role of several tobacco behaviours (smoking initiation, continuation, heaviness, and age at initiation). They showed that smoking continuation (current versus former smokers) was inversely associated with PD (OR per doubling of odds for smoking continuation $=0.64,95 \% \mathrm{Cl}=0.46-0.89, \mathrm{p}=0.008$ ) but smoking initiation, heaviness, or age at initiation were not. However, they used only 87 SNPs for smoking initiation and analyses were not stratified by smoking status for analyses of smoking characteristics among smokers.[35] The iPDGC PD MR Portal, a platform which offers MR analyses for a total of 5,839 GWAS versus the largest iPDGC GWAS available with some overlap with the two previous studies, also reports some evidence to support a protective effect of current smoking using a genetic instrument that included 12 SNPs.[36] These studies 
are not independent as they relied on overlapping datasets and did not examine associations in younger subjects or in those with shorter disease duration to assess whether survival or incidence-prevalence bias may have distorted MR estimates.

Our study replicates these findings and add further evidence in favour of an association between smoking initiation and lower PD risk; in addition, our findings show that genetic liability toward PD is not associated with smoking initiation which does not support the hypothesis of reverse causation for smoking. We further show that survival into old age and incidenceprevalence bias are unlikely explanations for the inverse association between smoking and PD. Since smoking is a major risk factor of mortality, differential survival could potentially bias the association between smoking-related SNP and PD; however, the observation that associations in younger participants were consistent with those seen overall is against this hypothesis and supports an association between smoking and PD.[9, 25-27] In addition, the finding that associations tended to be weaker in older participants than in younger ones is in agreement with some previous observational studies that showed age-dependent associations between smoking and PD with no association in the oldest age groups.[37, 38] This pattern could be interpreted in two different ways: (i) survival bias may have diluted association estimates in older subjects; (ii) alternatively, there may exist age-related etiologic heterogeneity in PD, and smoking may play a weaker role in PD at older ages where other factors may be more important. There was no marked difference in ORs according to disease duration, thus suggesting that incidence-prevalence bias is unlikely.

The consistency of MR findings with those from traditional epidemiologic studies and reports of smoking-by-gene interactions[39, 40] support a causal association between smoking and PD. However, the underlying mechanisms remain poorly understood. Although cigarette smoke includes a wide range of chemical components, a role for nicotine in PD was suggested by studies showing that it reduced neuronal damage in culture systems and protected against nigrostriatal dopaminergic damage in parkinsonian animal models.[41] In addition, among five compounds present in cigarette smoke (anabasine, cotinine, hydroquinone, nicotine, nornicotine), nicotine and hydroquinone inhibited alpha-synuclein aggregation.[42] 
Previous randomised clinical trials of nicotine for motor symptoms in PD failed to show an effect,[43-45] but their design may have been hampered by small sizes and short followup. In addition, these trials were conducted in PD patients and examined disease progression rather than prevention. Additional well-designed neuroprotection trials are needed.

\section{Alcohol drinking}

A meta-analysis of the relation between alcohol and PD reported an inverse association in case-control studies but not in cohort studies, with marked heterogeneity across studies.[46] Two of the cohort studies reported positive associations, while three reported inverse associations, but none of them was statistically significant.

A previous MR study that examined several risky behaviours in relation with PD using iPDGC data (9,581 cases, 33,245 controls) did not provide evidence in favour of an association for the number of drinks per week (70 SNPs; OR=1.15, $95 \% \mathrm{Cl}=0.87-1.53$ ) or alcohol consumption (7 SNPs; OR=1.39, 95\% Cl=0.11-17.56).[34] In contrast, another MR study that used the most recent iPDGC dataset showed an inverse and significant association with the number of drinks per weeks (OR=0.79, 95\%Cl=0.65-0.96, $\mathrm{p}=0.021 ; 33 \mathrm{SNPs})$.[28] We did not find a significant association with alcohol; however, given the low power of the study to detect an association with this exposure, we cannot draw firm conclusions.

Alternatively, reverse MR showed that genetic liability toward PD is positively associated with alcohol drinking, thus suggesting that persons at higher PD risk are more prone to drink alcohol, independently of whether they actually develop PD. This finding warrants further investigation and replication in further studies.

\section{Coffee drinking}

Previous studies, both case-control and cohort, have shown an inverse association between coffee drinking or caffeine intake and PD, with a dose-effect relationship, that was present after adjustment for smoking or in never-smokers.[47]

A previous MR study that assessed several risky behaviours in relation with PD using iPDGC data (9,581 cases, 33,245 controls) did not provide evidence in favour of an association for the number of coffee cups per day (4 SNPs; OR=1.03, 95\% $\mathrm{Cl}=0.65-1.63$ ). We did not find 
a significant association with coffee drinking, but given the low power of the study to detect an association with this exposure, we cannot draw firm conclusions. However, we did find that genetic liability toward PD was not associated with coffee drinking which does not support the hypothesis of reverse causation for coffee drinking.

\section{Strengths and weaknesses of the study}

Strengths of this study include the assessment of several lifestyle behaviours and use of data from a large consortium in which PD cases were carefully assessed by experienced movement disorders specialists. The MR design represents another strength as it avoids bias from reverse causation and confounding.[8] This approach, however, relies on a number of assumptions. We cannot exclude that our findings might have been affected by weak instrument bias. However, in MR analyses, the F-statistic was $>10$ for all exposures and bias from weak instruments is expected to be towards the null in a two-sample setting.[48] Pleiotropy is an important concern for MR analyses, and recent guidelines recommend using multiple methods that make different assumptions to assess the robustness of findings.[15] We used a number of approaches developed to address this issue, including the weighted median and mode, MR-Egger, and MR-PRESSO. Population stratification is unlikely to be a major concern for our analyses, as we restricted analyses within the Courage-PD consortium to individuals of European descent, cases were compared to controls from each site, and analyses were adjusted for principal components. Another strength of our study is that individual data on age at study and disease duration were available, which allowed us to run stratified analyses. Although stratification inevitably leads to a loss of statistical power, we were able to examine whether associations were consistent in younger participants and in those with shorter disease duration. As PD is a disease of old age, it is possible that genetic associations are biased by survival bias, but analyses in younger participants are unlikely to be biased as they did not reach the age where mortality rates are high.[9]

The main limitation of our study pertains to its statistical power. Our power calculations showed that our sample size was sufficient to detect ORs in the range of $0.4-0.6$ for a type-1 error rate of $1.7 \%$ to $5 \%$, for smoking and alcohol but not for coffee drinking. The highest power 
was noted for smoking initiation; the study was underpowered to detect weaker associations for coffee and alcohol drinking, hence limiting our ability to draw firm conclusions for these exposures. Please note that our study examined a limited number of exposures (selected a priori based on existing literature) and is not exploratory, and that the Bonferroni correction is conservative. Our aim was to assess whether MR findings were consistent with those from observational studies using different sets of genetic instruments and methods, and to perform subgroup sensitivity analyses to examine the robustness of our findings. One limitation of our analyses for smoking is that we were not able to stratify analyses by smoking status and to compare results in ever and never smokers using genetic instruments for smoking intensity or cessation.[49] We addressed this issue by using a lifetime smoking exposure index that takes into account several aspects of smoking and was developed in order to allow two-sample MR using data unstratified by smoking status.[17]

\section{Conclusions and future research}

Using an independent dataset, our study confirms previous MR findings adds further evidence in favour of a protective effect of smoking on PD and shows that this association is not explained by survival or incidence-prevalence bias. For alcohol and coffee drinking, larger studies and stronger genetic instruments are needed.

The number of PD cases is predicted to double between 2015-2040,[50] and the identification of neuroprotective strategies is a major goal. Our findings may help prioritise neuroprotective approaches for PD. Further research is necessary to improve genetic instruments for some of the exposures examined here, to understand the pathways involved in these associations, to determine whether these findings are corroborated in non-European populations, whether PD patients subgroups should be more specifically targeted, and whether there are critical periods of exposure. 


\section{Appendix}

Additional COURAGE-PD investigators: Sophia N Pchelina (Saint Petersburg, Russia), Thomas Brücke (Wien, Austria), Marie-Anne Loriot (Paris, France), Claire Mulot (Paris, France), Yves Koudou (Villejuif, France), Jean-Christophe Corvol (Paris, France), Georgia Xiromerisiou (Larissa, Greece), Christos Koros (Athens, Greece), Matina Maniati (Athens, Greece), Maria Bozi (Athens, Greece), Micol Avenali (Pavia, Italy), Margherita Canesi (Milan, Italy), Giorgio Sacilotto (Milan, Italy), Michela Zini (Milan, Italy), Roberto Cilia (Milan, Italy), Francesca Del Sorbo (Milan, Italy), Nicoletta Meucci (Milan, Italy), Letizia Straniero (Milan, Italy), Rosanna Asselta (Milan, Italy), Radha Procopio (Catanzaro, Italy), Aldo Quattrone (Catanzaro, Italy), Manabu Funayama (Tokyo, Japan), Aya Ikeda (Tokyo, Japan), Takashi Matsushima (Tokyo, Japan), Yuanzhe Li (Tokyo, Japan), Hiroyo Yoshino (Tokyo, Japan), Zied Landoulsi (Luxembourg, Luxembourg), Rubén Fernández-Santiago (Barcelona, Spain), Nicholas Wood (London, UK), Huw R Morris (London, UK). 


\section{Acknowledgments and sources of support}

- We thank the UK Biobank, GWAS and Sequencing Consortium of Alcohol and Nicotine use (GSCAN), the Bitter and sweet beverage consumption GWAS consortium and the Psychiatric Genetics Consortium for providing summary statistics for these analyses.

- This study used data from the COURAGE-PD consortium, conducted under a partnership agreement between 35 studies. The COURAGE-PD consortium is supported by the EU Joint Program for Neurodegenerative Disease research (JPND; https://www.neurodegenerationresearch.eu/initiatives/annual-calls-for-proposals/closedcalls/risk-factors-2012/risk-factor-call-results/courage-pd/).

- $C D$ is the recipient of a doctoral grant from Université Paris-Saclay, France.

- MS was supported by the grants from the German Research Council (DFG/SH 599/6-1), MSA Coalition, and Michael J Fox Foundation (USA Genetic Diversity in PD Program: GAPIndia Grant ID: 17473).

- ABS, DGH, and CE are funded by the Intramural Research Program of the National Institute on Aging, National Institutes of Health, Department of Health and Human Services, project ZO1 AG000949.

- ER is funded by the Canadian Consortium on Neurodegeneration in Aging.

- SK is funded by MSWA.

- PT is the recipient of an Estonian Research Council Grant PRG957.

- EMV is funded by the Italian Ministry of Health (Ricerca Corrente 2020).

- SB and JC are supported by grants from the National Research Foundation of South Africa (Grant Number: 106052); the South African Medical Research Council (Self-Initiated Research Grant); and Stellenbosch University, South Africa; they also acknowledge the support of the NRF-DST Centre of Excellence for Biomedical Tuberculosis Research; South African Medical Research Council Centre for Tuberculosis Research; Division of Molecular Biology and Human Genetics, Faculty of Medicine and Health Sciences, Stellenbosch University, Cape Town.

- PP and MDF have received funding from the Spanish Ministry of Science and Innovation (SAF2013-47939-R).

- KW and NLP are funded by the Swedish Research Council, grant numbers K2002-27X14056-02B, 521-2010-2479, 521-2013-2488, 2017-02175.

- NLP is funded by the National Institutes of Health, grant numbers ES10758 and AG 08724.

- CR is funded by the Märta Lundkvist Foundation, Swedish Brain Foundation, Karolinska Institutet Research Fund.

- ACB from the Swedish Brain Foundation, Swedish Research Council, Karolinska Institutet Research Funds.

- MT is funded by the Parkinson's UK.

- PG GEN sample collection was funded by the MRC and UK Medical Research Council (CEC, KEM).

- The sponsors had no role in the study design, data collection, data analysis, data interpretation, the writing of the report, or the decision to submit the paper for publication.

\section{Conflict of interest}

- PM reports grants from Fonds National de Recherche (FNR), grants from German Research Council (DFG), during the conduct of the study; and Patrick May is co-founder of MeGeno S.A., Esch-sur-Alzette, Luxembourg, a company for personal genomics.

- DRB is currently working as a staff scientist at Megeno S.A.

- ABS reports grants from Department of Defense, during the conduct of the study; grants from Michael J Fox Foundation, outside the submitted work.

- WP reports personal fees from Grünenthal, personal fees from AbbVie, personal fees from AOP Orphan, personal fees from Zambon, personal fees and other from Boehringer 
Ingelheim, personal fees from Stada, personal fees from UCB Pharma, outside the submitted work.

- AEL reports personal fees from AbbVie, personal fees from AFFiRis, personal fees from Janssen, personal fees from Biogen, personal fees from Merck, personal fees from Sun Pharma, personal fees from Corticobasal Solutions, personal fees from Sunovion, personal fees from Paladin, personal fees from Lilly, personal fees from Medtronic, personal fees from Theravance, personal fees from Lundbeck, personal fees from Retrophin, personal fees from Roche, personal fees from PhotoPharmics, outside the submitted work.

- $A B$ reports grants from France Parkinson + FRC, grants from ANR - EPIG - Agence nationale de recherche, grants from ANR - JPND - Agence nationale de recherche, grants from RDS (Roger de Spoelberch Foundation), grants from France Alzheimer, grants from Institut de France, grants from ANR - EPIG, grants from FMR (maladies rares), outside the submitted work.

- JCC reports grants from the Michael J Fox Foundation, Sanofi, and served in advisory boards for Air Liquide, Biogen, Denali, Ever Pharma, Idorsia, Prevail Therapeutic, Theranexus, UCB, outside the submitted work.

- MCCH reports grants from France Parkinson, grants from ANR -Agence nationale de recherche, (MetDePaDi, Synapark), grant from ANR - JPND (TransNeuro), Agence nationale de recherche, Grant; grants from Fondation de France, grants from the Michael J Fox Foundation, outside the submitted work.

- KB reports grants from MJFF, grants from BMBF, personal fees from Zambon, UCB, Abbvie, grants from University of Tuebingen, outside the submitted work.

- EMV reports speaking honoraria from Zambon; served as expert panelist for the International Parkinson and Movement Disorder Society; serves as Associate Editor of Journal of Medical Genetics, Section Editor of Pediatric Research, Member of the Editorial Board of Movement Disorders Clinical Practice; grants from the Italian Ministry of Health, CARIPLO Foundation, Pierfranco and Luisa Mariani Foundation, outside the submitted work.

- NH reports grants from - Japan Agency for Medical Research and Development (AMED), grants from - Japan Society for the Promotion of Science (JSPS), grants from - Ministry of Education Culture,Sports,Science and Technology Japan; Grant-in-Aid for Scientific Research on Innovative Areas, personal fees and other from Dai-Nippon Sumitomo Pharma Co.,Ltd, personal fees and other from Takeda Pharmaceutical Co.,Ltd., personal fees and other from Kyowa Kirin Co.,Ltd., personal fees and other from GSK K.K, personal fees and other from Nippon Boehringer Ingelheim,Co.,Ltd, personal fees and other from FP Pharmaceutical Corporation, personal fees and other from Eisai Co.,Ltd. , personal fees and other from Kissei Pharmaceutical Company, personal fees and other from Nihon Mediphysics Co.,Ltd, personal fees and other from Novartis Pharma K.K, personal fees and other from Biogen Idec Japan Ltd, personal fees and other from AbbVie, from Medtronic, Inc., other from Boston Scientific Japan, personal fees and other from Astellas Pharma Inc., grants and other from Ono Pharmaceutical Co.,Ltd, other from Nihon Pharmaceutical Co., Ltd, other from Asahi Kasei Medical Co.,Ltd, other from Mitsubishi Tanabe Pharma Corporation, personal fees and other from Daiichi Sankyo Co., other from OHARA Pharmaceutical Co.,Ltd, other from Meiji Seika Pharma, personal fees from Sanofi K.K., personal fees from Pfizer Japan Inc., personal fees from Alexion Pharmaceuticals, personal fees from Mylan N.V, personal fees from MSD K.K, personal fees from Lund Beck Japan, other from Hisamitsu Pharmaceutical Co., Inc, outside the submitted work.

- KN reports grants from - Japan Society for the Promotion of Science (JSPS), outside the submitted work.

- PK reports other from Centre Hospitalier de Luxembourg; University of Luxembourg, grants from Fonds National de Recherche (FNR), from null, outside the submitted work.

- BPCW reports grants from ZonMW, grants from Hersenstichting, grants from uniQure, other from uniQure, grants from Gossweiler Fund, grants from Radboud university medical centre, outside the submitted work. 
- BRB reports grants from Netherlands Organization for Health Research and Development , grants from Michael J. Fox Foundation, grants from Parkinson Vereniging, grants from Parkinson Foundation, grants from Gatsby Foundation, grants from Verily Life Sciences, grants from Horizon 2020, grants from Topsector Life sciences and Health, grants from Stichting Parkinson Fonds, grants from UCB, grants from Abbvie, during the conduct of the study; personal fees from Biogen, personal fees from Abbvie, personal fees from Walk with Path, personal fees from UCB, personal fees from Abbvie, personal fees from Zambon, personal fees from Bial, personal fees from Roche, outside the submitted work; and Serves as editor-in-chief of the Journal of Parkinson's Disease and serves on the editorial board of Practical Neurology and Digital Biomarkers.

- MT (M.Toft) reports grants from Research Council of Norway, during the conduct of the study; grants from South-Eastern Norway Regional Health Authority, grants from Michael J. Fox Foundation, outside the submitted work.

- LP reports grants from Norwegian Health Association, grants from South-Eastern Norway Regional Health Authority, outside the submitted work.

- JJF reports grants from GlaxoSmithKline, grants from Grunenthal, grants from Fundação MSD (Portugal), grants from TEVA, grants from MSD, grants from Allergan, grants from Novartis, grants from Medtronic, grants from GlaxoSmithKline, grants from Novartis, grants from TEVA, grants from Lundbeck, grants from Solvay, grants from BIAL, grants from Merck-Serono, grants from Merz, grants from Ipsen, grants from Biogen, grants from Acadia, grants from Allergan, grants from Abbvie, grants from Sunovion Pharmaceuticals, personal fees from Faculdade de Medicina de Lisboa, personal fees from CNS - Campus Neurológico Sénior, personal fees from BIAL, personal fees from Novartis, outside the submitted work.

- ET received honoraria for consultancy from TEVA, Bial, Prevail Therapeutics, Boehringer Ingelheim, Roche and BIOGEN and has received funding for research from Spanish Network for Research on Neurodegenerative Disorders (CIBERNED)- Instituto Carlos III (ISCIII), and The Michael J. Fox Foundation for Parkinson's Research(MJFF)

- KW reports grants from Swedish Research Council, during the conduct of the study.

- NLP reports grants from Swedish Research Council, during the conduct of the study.

- AP reports grants from Parkinsonfonden (The Swedish Parkinson Foundation), grants from ALF (Swedish Government), grants from Region Skåne, Sweden, grants from Hans-Gabriel och Trolle Wachtmeister Stiftelse för Medicinsk Forskning, Sweden, during the conduct of the study; personal fees from Elsevier, outside the submitted work.

- MT (M. Tan) reports grants from Parkinson's UK, other from Michael J Fox Foundation, other from University College London, outside the submitted work.

- RK reports grants from Fonds National de Recherche (FNR), grants from German Research Council (DFG), non-financial support from Abbvie, Zambon, during the conduct of the study; personal fees from University of Luxembourg; Luxembourg Institute of Health; Centre Hospitalier de Luxembourg , grants from Fonds National de Recherche, Luxembourg (FNR), grants from Fonds National de Recherche, Luxembourg (FNR), grants from Fonds National de Recherche (FNR), Luxembourg/German Research Council (DFG), grants from Fonds National de Recherche, Luxembourg (FNR), personal fees from Desitin/Zambon, personal fees from Abbvie $\mathrm{GmbH}$, personal fees from Medtronic $\mathrm{GmbH}$, outside the submitted work.

- TG reports personal fees from UCB Pharma, personal fees from Novartis, personal fees from Teva, personal fees from MedUpdate, grants from The Michael J Fox Foundation for Parkinson's Research, grants from Bundesministerium für Bildung und Forschung (BMBF), grants from Deutsche Forschungsgemeinschaft (DFG), other from "Joint Programming for Neurodegenerative Diseases"(JPND) program, funded by the European Commission, outside the submitted work; in addition, Dr. Gasser has a patent Patent Number: EP1802749 (A2) KASPP (LRRK2) gene, its production and use for the detection and treatment of neurodegenerative disorders issued. 


\section{References}

[1] Ascherio A, Schwarzschild MA (2016) The epidemiology of Parkinson's disease: risk factors and prevention. Lancet Neurol 15, 1257-1272.

[2] Bellou V, Belbasis L, Tzoulaki I, Evangelou E, loannidis JP (2016) Environmental risk factors and Parkinson's disease: An umbrella review of meta-analyses. Parkinsonism Relat Disord 23, 1-9.

[3] Elbaz A (2016) Prodromal symptoms of Parkinson's disease: Implications for epidemiological studies of disease etiology. Rev Neurol (Paris) 172, 503-511.

[4] Savica R, Boeve BF, Mielke MM (2018) When Do a-Synucleinopathies Start? An Epidemiological Timeline: A Review. JAMA Neurol 75, 503-509.

[5] Ritz B, Rhodes SL (2010) After half a century of research on smoking and PD, where do we go now? Neurology 74, 870-871.

[6] Ritz B, Lee PC, Lassen CF, Arah OA Parkinson disease and smoking revisited Ease of quitting is an early sign of the disease.

[7] Burgess S, Butterworth A, Thompson SG (2013) Mendelian randomization analysis with multiple genetic variants using summarized data. Genet Epidemiol 37, 658-665.

[8] Lawlor DA, Harbord RM, Sterne JA, Timpson N, Davey Smith G (2008) Mendelian randomization: using genes as instruments for making causal inferences in epidemiology. Stat Med 27, 1133-1163.

[9] Smit RAJ, Trompet S, Dekkers OM, Jukema JW, le Cessie S (2019) Survival Bias in Mendelian Randomization Studies: A Threat to Causal Inference. Epidemiology 30, 813-816.

[10] Boef AG, le Cessie S, Dekkers OM (2015) Mendelian randomization studies in the elderly. Epidemiology 26, e15-16.

[11] Ellenberg JH (1994) Differential postmorbidity mortality in observational studies of risk factors for neurologic disorders. Neuroepidemiology 13, 187-194.

[12] Blauwendraat C, Faghri F, Pihlstrom L, Geiger JT, Elbaz A, Lesage S, Corvol JC, May P, Nicolas A, Abramzon Y, Murphy NA, Gibbs JR, Ryten M, Ferrari R, Bras J, Guerreiro R, Williams J, Sims R, Lubbe S, Hernandez DG, Mok KY, Robak L, Campbell RH, Rogaeva E, Traynor BJ, Chia R, Chung SJ, International Parkinson's Disease Genomics Consortium C-PDC, Hardy JA, Brice A, Wood NW, Houlden H, Shulman JM, Morris HR, Gasser T, Kruger R, Heutink P, Sharma M, Simon-Sanchez J, Nalls MA, Singleton AB, Scholz SW (2017) NeuroChip, an updated version of the NeuroX genotyping platform to rapidly screen for variants associated with neurological diseases. Neurobiol Aging 57, 247 e249-247 e213.

[13] Machiela MJ, Chanock SJ (2015) LDlink: a web-based application for exploring population-specific haplotype structure and linking correlated alleles of possible functional variants. Bioinformatics 31, 3555-3557.

[14] Arnold M, Raffler J, Pfeufer A, Suhre K, Kastenmuller G (2015) SNiPA: an interactive, genetic variant-centered annotation browser. Bioinformatics 31, 1334-1336.

[15] Burgess S, Davey Smith G, Davies N, Dudbridge F, Gill D, Glymour M, Hartwig F, Holmes M, Minelli C, Relton C, Theodoratou E (2020) Guidelines for performing Mendelian randomization investigations [version 2; peer review: 1 approved, 1 approved with reservations]. Wellcome Open Research 4.

[16] Liu M, Jiang Y, Wedow R, Li Y, Brazel DM, Chen F, Datta G, Davila-Velderrain J, McGuire D, Tian C, Zhan X, andMe Research T, Psychiatry HA-I, Choquet H, Docherty AR, Faul JD, Foerster JR, Fritsche LG, Gabrielsen ME, Gordon SD, Haessler J, Hottenga JJ, Huang $H$, Jang SK, Jansen PR, Ling Y, Magi R, Matoba N, McMahon G, Mulas A, Orru V, Palviainen T, Pandit A, Reginsson GW, Skogholt AH, Smith JA, Taylor AE, Turman C, Willemsen G, Young H, Young KA, Zajac GJM, Zhao W, Zhou W, Bjornsdottir G, Boardman JD, Boehnke M, Boomsma DI, Chen C, Cucca F, Davies GE, Eaton CB, Ehringer MA, Esko T, Fiorillo E, Gillespie NA, Gudbjartsson DF, Haller T, Harris KM, Heath AC, Hewitt JK, Hickie IB, Hokanson JE, Hopfer CJ, Hunter DJ, Iacono WG, Johnson EO, Kamatani Y, Kardia SLR, Keller MC, Kellis M, Kooperberg C, Kraft 
P, Krauter KS, Laakso M, Lind PA, Loukola A, Lutz SM, Madden PAF, Martin NG, McGue M, McQueen MB, Medland SE, Metspalu A, Mohlke KL, Nielsen JB, Okada Y, Peters U, Polderman TJC, Posthuma D, Reiner AP, Rice JP, Rimm E, Rose RJ, Runarsdottir V, Stallings MC, Stancakova A, Stefansson H, Thai KK, Tindle HA, Tyrfingsson T, Wall TL, Weir DR, Weisner C, Whitfield JB, Winsvold BS, Yin J, Zuccolo L, Bierut LJ, Hveem K, Lee JJ, Munafo MR, Saccone NL, Willer CJ, Cornelis MC, David SP, Hinds DA, Jorgenson E, Kaprio J, Stitzel JA, Stefansson K, Thorgeirsson TE, Abecasis G, Liu DJ, Vrieze S (2019) Association studies of up to 1.2 million individuals yield new insights into the genetic etiology of tobacco and alcohol use. Nat Genet 51, 237-244.

[17] Wootton RE, Richmond RC, Stuijfzand BG, Lawn RB, Sallis HM, Taylor GMJ, Hemani G, Jones HJ, Zammit S, Davey Smith G, Munafo MR (2019) Evidence for causal effects of lifetime smoking on risk for depression and schizophrenia: a Mendelian randomisation study. Psychol Med 50, 2435-2443.

[18] Zhong VW, Kuang A, Danning RD, Kraft P, van Dam RM, Chasman DI, Cornelis MC (2019) A genome-wide association study of bitter and sweet beverage consumption. Hum Mol Genet 28, 2449-2457.

[19] Larsson SC, Traylor M, Malik R, Dichgans M, Burgess S, Markus HS, CoStream Consortium obotIGoAsP (2017) Modifiable pathways in Alzheimer's disease: Mendelian randomisation analysis. BMJ 359, j5375.

[20] Burgess S, Thompson SG (2017) Interpreting findings from Mendelian randomization using the MR-Egger method. Eur J Epidemiol 32, 377-389.

[21] Bowden J, Del Greco MF, Minelli C, Davey Smith G, Sheehan NA, Thompson JR (2016) Assessing the suitability of summary data for two-sample Mendelian randomization analyses using MR-Egger regression: the role of the 12 statistic. Int $J$ Epidemiol 45, 1961-1974.

[22] Bowden J, Davey SG, Haycock PC, Burgess S (2016) Consistent Estimation in Mendelian Randomization with Some Invalid Instruments Using a Weighted Median Estimator. Genet. Epidemiol 40, 304-314.

[23] Hartwig FP, Davey Smith G, Bowden J (2017) Robust inference in summary data Mendelian randomization via the zero modal pleiotropy assumption. Int J Epidemio/46, 1985-1998.

[24] Verbanck M, Chen CY, Neale B, Do R (2018) Detection of widespread horizontal pleiotropy in causal relationships inferred from Mendelian randomization between complex traits and diseases. Nat Genet 50, 693-698.

[25] Elbaz A, Alperovitch A (2002) Bias in association studies resulting from geneenvironment interactions and competing risks. Am J Epidemiol 155, 265-272.

[26] Schooling CM (2018) Selection bias in population-representative studies? A commentary on Deaton and Cartwright. Soc Sci Med 210, 70.

[27] Schooling CM (2019) Biases in GWAS - the dog that did not bark. bioRxiv, 709063.

[28] Nalls MA, Blauwendraat C, Vallerga CL, Heilbron K, Bandres-Ciga S, Chang D, Tan M, Kia DA, Noyce AJ, Xue A, Bras J, Young E, von Coelln R, Simón-Sánchez J, Schulte C, Sharma M, Krohn L, Pihlstrøm L, Siitonen A, Iwaki H, Leonard H, Faghri F, Gibbs JR, Hernandez DG, Scholz SW, Botia JA, Martinez M, Corvol JC, Lesage S, Jankovic J, Shulman LM, Sutherland M, Tienari P, Majamaa K, Toft M, Andreassen OA, Bangale T, Brice A, Yang J, Gan-Or Z, Gasser T, Heutink P, Shulman JM, Wood NW, Hinds DA, Hardy JA, Morris HR, Gratten J, Visscher PM, Graham RR, Singleton AB, on behalf of the 23andMe Research Team, System Genomics of Parkinson's Disease Consortium, Consortium tIPsDG (2019) Identification of novel risk loci, causal insights, and heritable risk for Parkinson's disease: a meta-analysis of genome-wide association studies. Lancet Neurol 18, 1091-1102.

[29] Burgess S, Labrecque JA (2018) Mendelian randomization with a binary exposure variable: interpretation and presentation of causal estimates. Eur J Epidemiol.

[30] Brion MJ, Shakhbazov K, Visscher PM (2013) Calculating statistical power in Mendelian randomization studies. Int. J. Epidemiol 42, 1497-1501. 
[31] Noyce AJ, Bestwick JP, Silveira-Moriyama L, Hawkes CH, Giovannoni G, Lees AJ, Schrag A (2012) Meta-analysis of early nonmotor features and risk factors for Parkinson disease. Ann Neurol 72, 893-901.

[32] Ritz B, Lee PC, Lassen CF, Arah OA (2014) Parkinson disease and smoking revisited: ease of quitting is an early sign of the disease. Neurology 83, 1396-1402.

[33] Gallo V, Vineis P, Cancellieri M, Chiodini P, Barker RA, Brayne C, Pearce N, Vermeulen R, Panico S, Bueno-de-Mesquita B, Vanacore N, Forsgren L, Ramat S, Ardanaz E, Arriola L, Peterson J, Hansson O, Gavrila D, Sacerdote C, Sieri S, Kühn T, Katzke VA, van der Schouw YT, Kyrozis A, Masala G, Mattiello A, Perneczky R, Middleton L, Saracci R, Riboli E (2019) Exploring causality of the association between smoking and Parkinson's disease. Int J Epidemiol 48, 912-925.

[34] Grover S, Lill CM, Kasten M, Klein C, Del Greco MF, Konig IR (2019) Risky behaviors and Parkinson disease: A mendelian randomization study. Neurology 93, e1412e1424.

[35] Dominguez-Baleon C, Ong JS, Scherzer CR, Renteria ME, Dong X (2021) Understanding the effect of smoking and drinking behavior on Parkinson's disease risk: a Mendelian randomization study. Sci Rep 11, 13980.

[36] Noyce AJ, Bandres-Ciga S, Kim J, Heilbron K, Kia D, Hemani G, Xue A, Lawlor DA, Smith GD, Duran R, Gan-Or Z, Blauwendraat C, Gibbs JR, andMe Research Team IPsDGC, Hinds DA, Yang J, Visscher P, Cuzick J, Morris H, Hardy J, Wood NW, Nalls MA, Singleton AB (2019) The Parkinson's Disease Mendelian Randomization Research Portal. Mov Disord.

[37] Tzourio C, Rocca WA, Breteler MM, Baldereschi M, Dartigues JF, Lopez-Pousa S, Manubens-Bertran JM, Alpérovitch A (1997) Smoking and Parkinson's disease. An age-dependent risk effect? The EUROPARKINSON Study Group. Neurology 49, 1267 1272.

[38] Ritz B, Ascherio A, Checkoway H, Marder KS, Nelson LM, Rocca WA, Ross GW, Strickland D, Van Den Eeden SK, Gorell J (2007) Pooled analysis of tobacco use and risk of Parkinson disease. Arch Neurol 64, 990-997.

[39] Lee PC, Ahmed I, Loriot MA, Mulot C, Paul KC, Bronstein JM, Ritz B, Elbaz A (2018) Smoking and Parkinson disease: Evidence for gene-by-smoking interactions. Neurology 90, e583-e592.

[40] Chuang YH, Lee PC, Vlaar T, Mulot C, Loriot MA, Hansen J, Lill CM, Ritz B, Elbaz A (2017) Pooled analysis of the HLA-DRB1 by smoking interaction in Parkinson disease. Ann Neurol 82, 655-664.

[41] Quik M, Perez XA, Bordia T (2012) Nicotine as a potential neuroprotective agent for Parkinson's disease. Mov Disord 27, 947-957.

[42] Hong DP, Fink AL, Uversky VN (2009) Smoking and Parkinson's disease: does nicotine affect alpha-synuclein fibrillation? Biochim Biophys Acta 1794, 282-290.

[43] Ebersbach G, Stöck M, Müller J, Wenning G, Wissel J, Poewe W (1999) Worsening of motor performance in patients with Parkinson's disease following transdermal nicotine administration. Mov Disord 14, 1011-1013.

[44] Vieregge A, Sieberer M, Jacobs H, Hagenah JM, Vieregge P (2001) Transdermal nicotine in PD: a randomized, double-blind, placebo-controlled study. Neurology 57, $1032-1035$.

[45] Villafane G, Thiriez C, Audureau E, Straczek C, Kerschen P, Cormier-Dequaire F, Van Der Gucht A, Gurruchaga JM, Quéré-Carne M, Evangelista E, Paul M, Defer G, Damier P, Remy P, Itti E, Fénelon G (2018) High-dose transdermal nicotine in Parkinson's disease patients: a randomized, open-label, blinded-endpoint evaluation phase 2 study. Eur J Neurol 25, 120-127.

[46] Jimenez-Jimenez FJ, Alonso-Navarro H, Garcia-Martin E, Agundez JAG (2019) Alcohol consumption and risk for Parkinson's disease: a systematic review and metaanalysis. J Neurol 266, 1821-1834.

[47] Qi H, Li S (2014) Dose-response meta-analysis on coffee, tea and caffeine consumption with risk of Parkinson's disease. Geriatr Gerontol Int 14, 430-439. 
[48] Pierce BL, Burgess S (2013) Efficient design for Mendelian randomization studies: subsample and 2-sample instrumental variable estimators. Am. J. Epidemiol 178, 1177-1184.

[49] Gage SH, Davey Smith G, Ware JJ, Flint J, Munafo MR (2016) G = E: What GWAS Can Tell Us about the Environment. PLoS Genet 12, e1005765.

[50] Dorsey ER, Bloem BR (2018) The Parkinson Pandemic-A Call to Action. JAMA Neurol 75, 9-10. 
Table 1: Effect of genetically-predicted smoking on PD.

\begin{tabular}{|c|c|c|}
\hline Exposure & Odds ratio $(95 \% \mathrm{Cl})$ & P-value \\
\hline \multicolumn{3}{|c|}{ Smoking initiation (per 1-SD increase in the prevalence of ever smoking) } \\
\hline IVW (p-heterogeneity=0.39) & $0.74(0.60-0.93)$ & 0.009 \\
\hline Weighted median & $0.64(0.47-0.89)$ & 0.008 \\
\hline Weighted mode & $0.58(0.24-1.42)$ & 0.23 \\
\hline MR Egger ( $p$-pleiotropy=0.59; $\left.\right|^{2} \mathrm{GX}=0.66$ ) & $0.59(0.24-1.45)$ & 0.25 \\
\hline Corrected MR Egger & $0.56(0.22-1.39)$ & 0.26 \\
\hline
\end{tabular}

MR-PRESSO (p-pleiotropy $=0.24)$

\section{Lifetime smoking index (per 1-unit) ${ }^{\mathrm{a}}$}

IVW ( $p$-heterogeneity $=0.007$ )

$0.54(0.29-1.00) \quad 0.050$

Weighted median

$0.37(0.16-0.84) \quad 0.017$

Weighted mode

$0.29(0.06-1.34) \quad 0.12$

MR Egger ( $p$-pleiotropy=0.93; $\left.\left.\right|^{2} \mathrm{GX}=0.64\right)$

$0.60(0.05-6.77) \quad 0.68$

Corrected MR Egger

$0.60(0.06-6.47) \quad 0.68$

MR-PRESSO $(p-\text { pleiotropy }=0.010, p \text {-distortion }=0.77)^{b}$

$0.51(0.29-0.89) \quad 0.021$

$\mathrm{Cl}$, confidence interval; IVW, inverse variance weighted.

a In the UK Biobank, the lifetime smoking index had a mean of 0.359 and a standard deviation (SD) of 0.694 ; a $1-S D$ increase in the lifetime smoking index is equivalent to an individual smoking 20 cigarettes a day for 15 years and stopping 17 years ago or an individual smoking 60 cigarettes a day for 13 years and stopping 22 years ago. The ORıvw for a 1-SD increase is $0.67^{0.694}=0.76$.

b Outliers: rs202645. 
Table 2: Effect of genetically-predicted alcohol drinking on PD.

\begin{tabular}{lcc}
\hline Exposure & Odds ratio (95\% Cl) & P-value \\
\hline \multicolumn{2}{l}{ Alcohol drinking (per 1-SD increase of In(drinks per week)) } & \\
IVW (p-heterogeneity=0.062) & $0.68(0.39-1.18)$ & 0.17 \\
Weighted median & $0.86(0.42-1.75)$ & 0.67 \\
Weighted mode & $0.86(0.41-1.77)$ & 0.68 \\
MR Egger (p-pleiotropy=0.94; $\left.\left.\right|^{2} G X=0.96\right)$ & $0.70(0.30-1.61)$ & 0.40 \\
MR-PRESSO (p-pleiotropy=0.042, p-distortion=0.73a) & $0.77(0.46-1.29)$ & 0.33
\end{tabular}

Alcohol drinking: after exclusion of 2 SNPs associated with coffee drinking:

rs1260326 and rs2472297 (per 1-SD increase of In(drinks per week)

IVW (p-heterogeneity $=0.11)$

$0.78(0.45-1.35) \quad 0.37$

Weighted median

$0.88(0.44-1.76) \quad 0.72$

Weighted mode

$0.85(0.46-1.58) \quad 0.61$

MR Egger ( $p$-pleiotropy=0.98; $\left.{ }^{2} \mathrm{GX}=0.96\right)$

$0.78(0.34-1.78) \quad 0.56$

MR-PRESSO (p-pleiotropy $=0.089$ )

Cl, confidence interval; IVW, inverse variance weighted.

a Outliers: rs9607814. 
Table 3: Effect of genetically-predicted coffee drinking on PD.

\begin{tabular}{lcc}
\hline Exposure & Odds ratio (95\% Cl) & P-value \\
\hline Coffee drinking (per In(cups per day)) & & \\
IVW (p-heterogeneity=0.017) & $1.69(0.51-5.63)$ & 0.40 \\
Weighted median & $1.51(0.50-4.51)$ & 0.47 \\
Weighted mode & $1.45(0.52-4.03)$ & 0.50 \\
MR Egger ( $p$-pleiotropy=0.73; | $\left.{ }^{2} \mathrm{GX}=0.97\right)$ & $2.50(0.21-29.59)$ & 0.49 \\
MR-PRESSO (p-pleiotropy=0.035, p-distortion $=0.86)^{\mathrm{a}}$ & $1.86(0.67-5.11)$ & 0.26
\end{tabular}

Coffee drinking: after exclusion of 2 SNPs associated with alcohol drinking:

rs1260326 and rs2472297 (per In(cups per day))

IVW (p-heterogeneity=0.053)

$1.09(0.26-4.45) \quad 0.91$

Weighted median

$1.06(0.32-3.53) \quad 0.93$

Weighted mode

$1.11(0.31-4.01) \quad 0.88$

MR Egger ( $p$-pleiotropy=0.35; $\left.\left.\right|^{2} \mathrm{GX}=0.96\right)$

$3.86(0.22-66.63) \quad 0.38$

MR-PRESSO (p-pleiotropy=0.12)

Cl, confidence interval; IVW, inverse variance weighted.

a Outlier: rs574367. 
Table 4: Reverse Mendelian randomisation using PD-associated SNPs from iPDGC (Nalls et al. 2019)[28] as genetic instruments.

\begin{tabular}{|c|c|c|c|c|}
\hline Method & OR $(95 \% \mathrm{Cl})$ & P-value & P-het. & P-pleio. \\
\hline Smoking initiation & 64 SNPs & & & \\
\hline IVW & $1.01(0.99-1.02)$ & 0.18 & $<0.001$ & \\
\hline Weighted median & $1.01(0.99-1.02)$ & 0.36 & & \\
\hline Weighted mode & $1.01(0.99-1.03)$ & 0.35 & & \\
\hline MR-Egger & $1.02(0.99-1.05)$ & 0.15 & & 0.36 \\
\hline MR-PRESSO & - & - & & $<0.001^{a}$ \\
\hline Lifetime smoking index & 65 SNPs & & & \\
\hline IVW & $1.00(0.99-1.01)$ & 0.83 & $<0.001$ & \\
\hline Weighted median & $1.00(0.99-1.01)$ & 0.38 & & \\
\hline Weighted mode & $0.99(0.98-1.01)$ & 0.092 & & \\
\hline MR-Egger & $1.01(0.99-1.02)$ & 0.34 & & 0.23 \\
\hline MR-PRESSO & $1.00(0.99-1.01)$ & 0.56 & & $<0.001^{b}$ \\
\hline Alcohol drinking & 64 SNPs & & & \\
\hline IVW & $1.02(1.01-1.03)$ & 0.002 & $<.001$ & \\
\hline Weighted median & $1.01(0.99-1.02)$ & 0.14 & & \\
\hline Weighted mode & $1.01(0.99-1.02)$ & 0.21 & & \\
\hline MR-Egger & $1.02(0.99-1.04)$ & 0.097 & & 0.85 \\
\hline MR-PRESSO & $1.01(1.00-1.02)$ & 0.042 & & $<.001^{\mathrm{c}}$ \\
\hline
\end{tabular}

\section{Coffee drinking}

65 SNPs

IVW

$\begin{array}{lll}1.00(0.99-1.01) & 0.15 & <0.001 \\ 1.00(0.99-1.01) & 0.82 & \\ 1.00(0.99-1.01) & 0.65 & \\ 1.00(0.99-1.01) & 0.69 \\ 1.00(0.99-1.01) & 0.25 & \end{array}$

MR-Egger

0.25

$<0.001^{\mathrm{d}}$

OR, odds ratio per 1-unit increase in log odds of liability to PD; IVW, inverse-variance weighted (random-effect); $\mathrm{Cl}$, confidence interval; p-het., p for heterogeneity (IVW); p-pleio., p for pleiotropy (MR-Egger and MR-PRESSO).

aNo outlier detected.

bOutliers: rs12497850, rs12600861, and rs62053943; p-distortion=NS.

'Outliers: rs62053943, rs6476434, rs6854006, rs7134559, and rs823118; p-distortion=0.041.

dOutliers: rs2248244 and rs61169879; p-distortion=NS. 


\section{Figure 1}

Title Forest plot showing MR estimates for the association of smoking initiation and a lifetime smoking index with PD, overall and after stratification by age at study and disease duration in cases.

$\mathrm{OR}=$ odds ratio $; \mathrm{Cl}=$ confidence interval.

OR

Group

with $95 \% \mathrm{Cl}$

\section{A-Smoking initiation}

All individuals

Age $\leq 67$ years

Age $>67$ years

Disease duration $\leq 7$ years

Disease duration $>7$ years

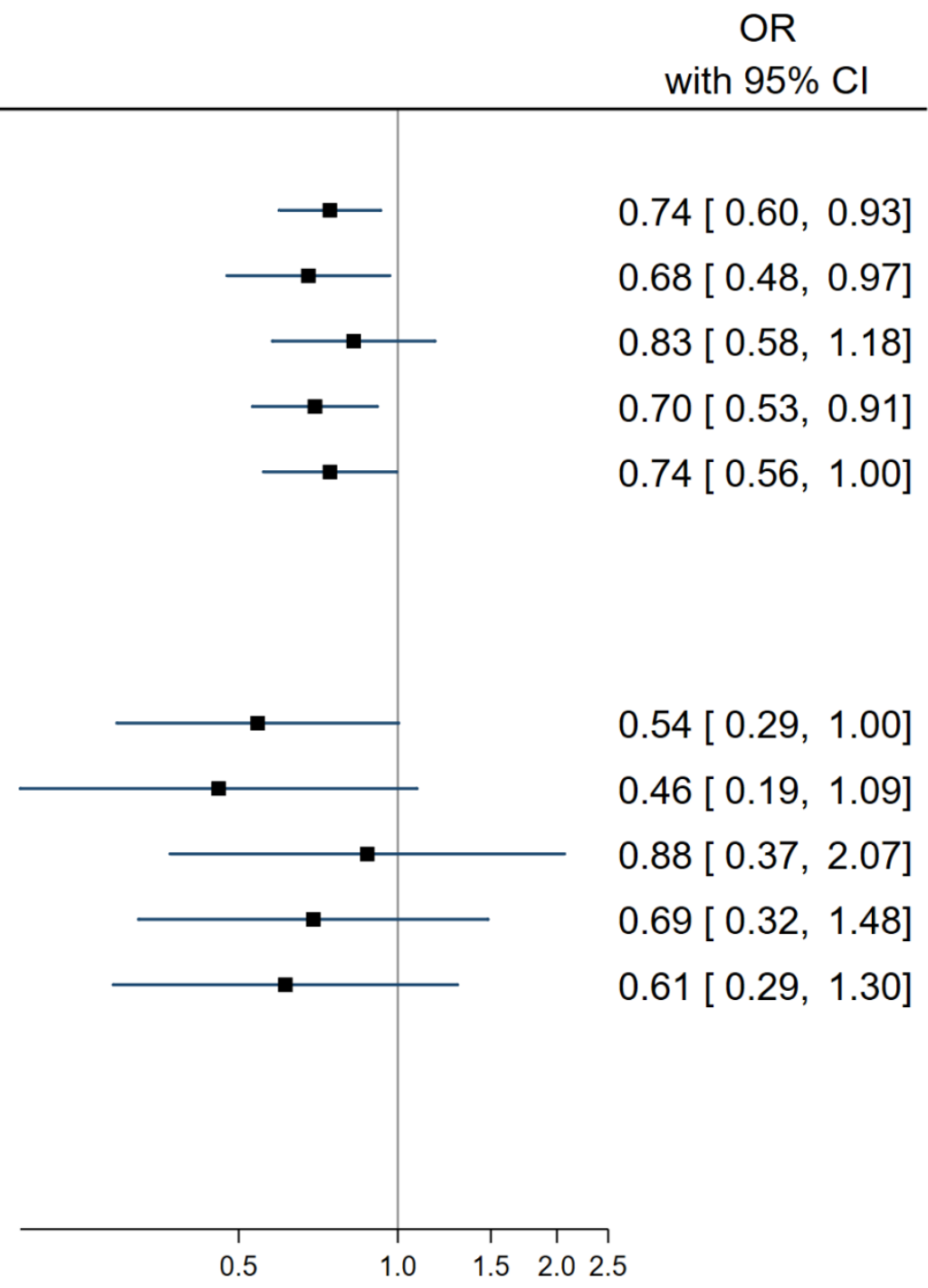




\section{Supplementary material}

Supplementary methods

Supplementary table 1: Characteristics of cases and controls from the Courage-PD consortium by study site (after quality control).

Supplementary table 2: Statistical power to detect odds ratios comprised between 0.3 and 0.9 for two values of type-1 error in Mendelian randomization analyses in the Courage-PD consortium (7,369 cases, 7,018 controls)...8

Supplementary table 3: SNPs used for Mendelian randomization analyses: individual associations with exposures and PD.

Supplementary table 4: SNPs used for Mendelian randomization analyses: individual associations with PD stratified by age and disease duration.

Supplementary table 5: Number of SNPs retained for each exposure in Mendelian randomization analyses and distribution of F-statistics...

Supplementary table 6: Mendelian randomization analyses stratified by age at study

Supplementary table 7: Mendelian randomization analyses stratified by disease duration in PD cases.

Supplementary table 8: SNPs used for reverse Mendelian randomization analyses: individual associations with PD (exposure) and smoking, alcohol, and coffee drinking (outcomes).

Supplementary figure 1: Survival bias in Mendelian randomization studies of diseases in elderly populations. ....36

Supplementary figure 2: MR analyses of the relation of smoking, alcohol, and coffee drinking with PD: (A) Plots relating the effects sizes of the SNP-exposure (x-axis) and SNP-PD (y-axis, log OR) associations with standard error bars: the slope of the lines corresponds to causal estimates using different methods; (B) funnel plots of individual variant effects plotted against the inverse of their standard error.

Supplementary figure 3: Reverse MR analyses of the relation of PD with smoking initiation, lifetime smoking index, and alcohol and coffee drinking: (A) Plots relating the effects sizes of the SNP-PD ( $x$-axis) and SNPoutcomes (smoking, coffee, alcohol; $y$-axis, log OR) associations with standard error bars: the slope of the lines corresponds to causal estimates using different methods; (B) funnel plots of individual variant effects plotted against the inverse of their standard error. 


\section{Supplementary methods}

\section{Courage-PD international consortium}

The Courage-PD (COmprehensive Unbiased Risk Factor Assessment for Genetics and Environment in Parkinson's Disease) international consortium pooled individual-level data from 35 studies on Parkinson's disease (PD) from different populations worldwide and used the same array to genotype their participants.

The Geo-PD (Genetic Epidemiology Of Parkinson's disease; https://geopd.biomedinfo.org/) consortium represents one of the components of Courage-PD. This consortium aims at conducting collaborative studies on genetic susceptibility in PD; one of its main features is that participating sites are distributed in the five continents, therefore representing a highly diverse population. In addition, several other studies from Europe contributed to Courage-PD. PD was diagnosed using standard criteria (United Kingdom Parkinson's Disease Society Brain Bank - UKPDSBB, Gelb, Bower). ${ }^{1-3}$

All studies were approved by local ethical committees following the procedures of each country, and material transfer agreements were set up between participating sites and the University of Tübingen (Germany).

According to the study's consortium agreement, participating sites contributed DNA and demographic/environmental data. DNAs $(25 \mu \mathrm{l}$ of DNA at a concentration of 50 to $100 \mathrm{ng} / \mu \mathrm{l})$ were shipped for quality control to University of Tübingen (Germany) and genotyped in a central laboratory in Munich (Institute of Human Genetics, Helmholtz Zentrum, Germany). The samples from two sites (Gasser, Morris/Wood) were genotyped at the Laboratory of Neurogenetics (National Institute on Aging, National Institutes of Health, Bethesda, USA). Demographic data were harmonized and collected using a standardized form and cleaned at Inserm U1018 (Villejuif, France).

\section{Genotyping}

The Neurochip chip was used to genotype all the samples. ${ }^{4}$ Briefly, this chip is a custom-designed array containing a tagging variant backbone with good genome-wide resolution of about 306,670 , complemented with a manually curated custom content comprised of 179,467 variants implicated in diverse neurological diseases, including PD.

Genotyping was performed with an automated protocol according to the manufacturer's instructions (lllumina, San Diego, CA, USA). All arrays were scanned with an Illumina iScan and raw data were analyzed with the Illumina Beeline and GenomeStudio software packages using the manifest file Neuro_Consortium_20013217_A1.bpm. Clustering was performed in GenomeStudio with the GenTrain 
cluster 2.0 algorithm. Genotypes were post-processed with zCall (DOI: 10.1093/bioinformatics/bts479) to improve detection of rare alleles.

\section{Quality control}

Genotyped data exported from Genome Studio to PLINK format were used for quality control and downstream analysis. The pooled dataset from the 35 sites consists of 27,538 subjects. Phenotypic data were missing for 245 subjects and three sites were removed as they only included cases, leaving 26,535 subjects (14,859 cases, 11,431 controls) for quality control using "COMRARE" an automated pipeline under development at the University of Tübingen. The pipeline uses PLINK (https://www.coggenomics.org/plink) and R scripts ( $\mathrm{R}$ Foundation for Statistical Computing, Vienna, Austria) and the following steps were implemented separately for each site:

1- Per individual quality control:

- Identification of individuals with elevated missing genotyping rates or outlying heterozygosity rate: individuals with a genotype failure rate $\geq 4 \%$ or heterozygosity rate \pm 4 standard deviations from the mean were excluded.

- Identification of Individuals with discordant sex information: the homozygosity rate was calculated for X-linked SNPs for each individual and compared to the expected rate. Participants for whom phenotypic and genotypic sex were discordant were removed.

- Identification of duplicated or related Individuals: pairs of individuals with an identity by descent (IBD) greater than 0.185 were removed.

- Eigensoft software was used to compute principal components in order to correct for population stratification by merging our dataset with HapMap. ${ }^{5}{ }^{6} \mathrm{~A}$ scatter plot of the first two principal components was used to identify outliers in each study.

2- Per marker quality control:

- Identification of markers with high missing data rate: a call-rate threshold of $4 \%$ was used and SNPs with a lower rate were removed.

- SNPs with a significant $\left(\mathrm{P}<10^{-5}\right)$ difference in rates of missing values between cases and controls were removed.

- We excluded variants with a minor allele frequency (MAF) $<5 \times 10^{-8}$ and those in HardyWeinberg disequilibrium $\left(P<5 \times 10^{-8}\right)$. 


\section{Imputation}

After QC, we used the HRC/1000G imputation preparation and checking tool (https://www.well.ox.ac.uk/ wrayner/tools/HRC-1000G-check-bim-v4.3.0.zip) to check for Ref/Alt allele assignments, incorrect strands, deviation from allele frequency, and palindromic SNPs. Imputation of autosomal variants was performed separately for each dataset based on based on 271,398 to 373,664 SNPs in each study, through the Michigan Imputation server using the HRC reference panel and the GRCh37/hg19 assembly with a $R^{2}$ filter of 0.3 . The mean of the number of SNPs available in each study after imputation was $13,710,549(\mathrm{SD}=2,986,478)$.

\section{Association analysis and meta-analysis}

We excluded from our analyses samples overlapping with the international Parkinson Disease Genomics Consortium (iPDGC) which included all the samples from three sites (Pastor/Diez-Fairen, Spain; Toft, Norway; Morris/Wood, UK) as well as 1,000 samples from the Gasser/Sharma (Germany) site (642 cases, 358 controls) and 137 samples of PD cases from the Tolosa site (Spain). Analyses are also restricted to sites that provided samples for both cases and controls and to participants of Caucasian ancestry; only sites with at least 50 cases or 50 controls were included. In addition, as the role of environmental factors may be different in carriers of Mendelian PD mutations, we excluded participants with GBA/LRRK2 mutations or positive family history of PD. The main characteristics of 7,369 cases and 7,018 controls from 23 sites included in the analyses are shown in Supplementary table 1.

We excluded SNPs with a MAF $<1 \%$, in Hardy-Weinberg disequilibrium $\left(\mathrm{P}<5 \times 10^{-8}\right)$, and those with low imputation quality $\left(r^{2}<0.8\right)$. The final number of SNPs available for analysis in each study was comprised between $5,934,239$ and $7,168,307$. Only SNPs available in $75 \%(n=17)$ of the studies or more were retained for further analyses.

For our MR analyses, we selected a total of 411 SNPs, of which 6 were not available and 37 excluded (Supplementary table 5). Therefore, the final number of SNPs used in the analyses was of 368 SNPs, of which $93 \%$ were available in all studies. Of these SNPs, 27 were genotyped and 341 were imputed; when genotyped SNPs were available, we selected them in priority.

For each site, logistic regression adjusted for sex and the first four principal components was performed for each SNP under an additive genetic model (number of alleles for genotyped SNPs, dosage for imputed SNPs) using PLINK software (version 1.9). ${ }^{7}$

Summary statistics from the GWAS of the 23 studies were meta-analysed using the GWAMA software. ${ }^{8}$ To assess heterogeneity of genetic associations with each SNP in Courage-PD, we used the ${ }^{2}$ 
statistic; $I^{2}$ values of 0 to $24 \%$ suggest little heterogeneity, 25 to $49 \%$ reflect moderate heterogeneity, 50 to $74 \%$ reflect large heterogeneity, and $>75 \%$ reflect very large heterogeneity. Effects size and standard errors of SNPs with little heterogeneity across studies $\left(I^{2} \leq 25 \%\right)$ were combined using a fixed-effect model, while we used a random-effects model for SNPs with higher heterogeneity $\left(I^{2}>25 \%\right)$. Of 368 SNPs used in our MR analyses, $324(88 \%)$ displayed little heterogeneity and $44(12 \%)$ had moderate heterogeneity; there were no SNPs with $\mathrm{I}^{2}$ above $50 \%$.

Analyses were first performed overall. We then repeated our analyses: (I) in two groups defined by median age at study ( $\leq 67$ years, $>67$ years; 6,086 cases and 5,672 controls from 19 studies); (ii) in two groups defined by median disease duration in PD cases ( $\leq 7$ years, $N=3,633 ;>7$ years, $N=3,271$ ) from 22 studies (cases from each group were compared to all controls).

\section{References}

1. Gelb DJ, Oliver E, Gilman S. Diagnostic criteria for Parkinson disease. Arch Neurol 1999;56(1):33-9.

2. Gibb WR, Lees AJ. The relevance of the Lewy body to the pathogenesis of idiopathic Parkinson's disease. J Neurol Neurosurg Psychiatry 1988;51(6):745-52.

3. Bower JH, Maraganore DM, McDonnell SK, et al. Incidence and distribution of parkinsonism in Olmsted County, Minnesota, 1976-1990. Neurology 1999;52(6):1214-20.

4. Blauwendraat C, Faghri F, Pihlstrom L, et al. NeuroChip, an updated version of the NeuroX genotyping platform to rapidly screen for variants associated with neurological diseases. Neurobiol Aging 2017;57:247.e9-47.e13.

5. Price AL, Patterson NJ, Plenge RM, et al. Principal components analysis corrects for stratification in genome-wide association studies. Nat Genet 2006;38(8):904-9.

6. Patterson N, Price AL, Reich D. Population Structure and Eigenanalysis. PLOS Genetics 2006;2(12):e190.

7. Purcell S, Neale B, Todd-Brown K, et al. PLINK: a tool set for whole-genome association and populationbased linkage analyses. American journal of human genetics 2007;81(3):559-75.

8. Magi R, Morris AP. GWAMA: software for genome-wide association meta-analysis. BMC Bioinformatics 2010;11:288. 
Supplementary table 1: Characteristics of cases and controls from the Courage-PD consortium by study site (after quality control).

\begin{tabular}{|c|c|c|c|c|c|c|c|c|c|c|c|c|c|c|c|c|c|}
\hline \multirow[b]{2}{*}{ Continent } & \multirow{2}{*}{$\begin{array}{l}\text { Principal } \\
\text { investigators }\end{array}$} & \multirow[b]{2}{*}{ Country } & \multirow[b]{2}{*}{ Status } & \multirow[b]{2}{*}{$\mathbf{N}$} & \multicolumn{2}{|c|}{$\operatorname{Sex}(\%)$} & \multicolumn{3}{|c|}{ Age at study } & \multicolumn{3}{|c|}{ Age at PD onset } & \multicolumn{3}{|c|}{ Age at PD diagnosis } & \multicolumn{2}{|c|}{ Disease duration $^{b}$} \\
\hline & & & & & Male & Female & Mean & SD & MD & Mean & SD & MD & Mean & SD & MD & Mean & SD \\
\hline \multirow[t]{2}{*}{ Africa } & Bardien/Carr ${ }^{\mathrm{a}}$ & South Africa & Cases & 117 & 59.8 & 40.2 & 68.2 & 11.2 & & 59.6 & 12.6 & & 59.6 & 12.6 & & 8.5 & 6.7 \\
\hline & & & Controls & 80 & 57.5 & 42.5 & 50.8 & 12.6 & & - & - & & - & - & & - & - \\
\hline North & Farrer ${ }^{a}$ & United States & Cases & 262 & 66.4 & 33.6 & 66.9 & 10.4 & 1 & 55.8 & 11.5 & 1 & 58.6 & 11.5 & 96 & 11.0 & 6.5 \\
\hline \multirow[t]{3}{*}{ America } & & & Controls & 394 & 31.0 & 69.0 & 69.4 & 12.2 & & - & - & & - & - & & - & - \\
\hline & Rogaeva/Lang ${ }^{a}$ & Canada & Cases & 159 & 66.0 & 34.0 & 62.6 & 13.0 & 5 & 52.8 & 12.8 & 5 & & & 159 & 9.8 & 5.9 \\
\hline & & & Controls & 149 & 38.9 & 61.1 & 74.0 & 8.6 & & - & - & & - & - & & - & - \\
\hline \multirow[t]{2}{*}{ Australia } & Mellick $^{\mathrm{a}}$ & Australia & Cases & 399 & 64.9 & 35.1 & 68.2 & 9.3 & & 59.1 & 11.5 & & 60.7 & 10.8 & 8 & 9.2 & 7.1 \\
\hline & & & Controls & 399 & 48.4 & 51.6 & 67.7 & 9.0 & & - & - & & - & - & & - & - \\
\hline \multirow[t]{24}{*}{ Europe } & Aaslya & Norway & Cases & 463 & 59.6 & 40.4 & 78.2 & 11.2 & & 61.1 & 10.8 & & & & 463 & 17.1 & 5.4 \\
\hline & & & Controls & 487 & 54.2 & 45.8 & 73.2 & 14.1 & 74 & - & - & & - & - & & - & - \\
\hline & Annesi $^{a}$ & Italy & Cases & 89 & 65.2 & 34.8 & 66.8 & 9.0 & & 59.6 & 10.1 & & 66.8 & 9.0 & & 7.2 & 5.6 \\
\hline & & & Controls & 93 & 46.2 & 53.8 & 58.6 & 20.1 & & - & - & & - & - & & - & - \\
\hline & Brice/Corvol/Lesage ${ }^{a}$ & France & Cases & 745 & 59.6 & 40.4 & 61.1 & 10.8 & 25 & 52.1 & 11.0 & 25 & & & 745 & 8.9 & 6.3 \\
\hline & & & Controls & 275 & 56.4 & 43.6 & 62.4 & 10.6 & & - & - & & - & - & & - & - \\
\hline & Carmine Belin/Rana & Sweden & Cases & 214 & 63.6 & 36.4 & 67.2 & 10.3 & & 58.6 & 11.0 & & & & 214 & 8.6 & 6.2 \\
\hline & & & Controls & 611 & 54.8 & 45.2 & 66.3 & 9.8 & 583 & - & - & & - & - & & - & - \\
\hline & Chartier-Harlin/Muttez ${ }^{\mathrm{a}}$ & France & Cases & 285 & 55.8 & 44.2 & 64.3 & 9.0 & & 52.3 & 10.3 & & 53.3 & 10.1 & & 12 & 5.9 \\
\hline & & & Controls & 217 & 38.7 & 61.3 & 59.8 & 12.5 & & - & - & & - & - & & - & - \\
\hline & Deutschländer ${ }^{a}$ & Germany & Cases & 264 & 61.7 & 38.3 & 69.6 & 9.9 & & 60.7 & 11.4 & & 59.6 & 10.7 & 199 & 8.9 & 6.6 \\
\hline & & & Controls & 40 & 32.5 & 67.5 & 66.3 & 10.2 & & - & - & & - & - & & - & - \\
\hline & Elbaz $^{\mathrm{a}}$ & France & Cases & 387 & 60.5 & 39.5 & 70.1 & 7.3 & & 65 & 7.6 & & 65.9 & 7.4 & 1 & 5.2 & 4.1 \\
\hline & & & Controls & 998 & 59.0 & 41.0 & 69.8 & 7.6 & & - & - & & - & - & & - & - \\
\hline & Ferreira & Portugal & Cases & 313 & 58.5 & 41.5 & 69.1 & 10.1 & & 58.5 & 11.7 & & 60.2 & 11.8 & & 10.6 & 7.2 \\
\hline & & & Controls & 53 & 26.4 & 73.6 & 46.9 & 18.7 & & - & - & & - & - & & - & - \\
\hline & Gasser/Sharma ${ }^{c}$ & Germany & Cases & 432 & 65.0 & 35.0 & 65.8 & 10.8 & & 60.4 & 11.2 & & 60.4 & 11.2 & 129 & 5.3 & 5.1 \\
\hline & & & Controls & 388 & 43.0 & 57.0 & 62.9 & 7.3 & & - & - & & - & - & & - & - \\
\hline & Duga/Ciliaa & Italy & Cases & 1340 & 59.3 & 40.7 & 65.9 & 10.9 & & 59.1 & 11.3 & & 60.7 & 11.1 & & 6.8 & 5.6 \\
\hline & & & Controls & 1328 & 34.3 & 65.7 & 61.9 & 10.9 & & - & - & & - & - & & - & - \\
\hline & Hadjigeorgioua & Greece & Cases & 256 & 48.4 & 51.6 & 67.6 & 10.4 & & 62.8 & 10.3 & & 63.7 & 10.4 & & 4.8 & 4.4 \\
\hline & & & Controls & 310 & 47.4 & 52.6 & 69.8 & 8.7 & & - & - & & - & - & & - & - \\
\hline & Koks/Taba ${ }^{a}$ & Estonia & Cases & 210 & 40.0 & 60.0 & 73.0 & 8.2 & & 66.7 & 9.8 & & & & 210 & 6.3 & 5.4 \\
\hline & & & Controls & 163 & 41.1 & 58.9 & 72.6 & 10.1 & & - & - & & - & - & & - & - \\
\hline
\end{tabular}




\begin{tabular}{|c|c|c|c|c|c|c|c|c|c|c|c|c|c|c|c|c|c|}
\hline \multirow[b]{2}{*}{ Continent } & \multirow{2}{*}{$\begin{array}{l}\text { Principal } \\
\text { investigators }\end{array}$} & \multirow[b]{2}{*}{ Country } & \multirow[b]{2}{*}{ Status } & \multirow[b]{2}{*}{$\mathbf{N}$} & \multicolumn{2}{|c|}{$\operatorname{Sex}(\%)$} & \multicolumn{3}{|c|}{ Age at study } & \multicolumn{3}{|c|}{ Age at PD onset } & \multicolumn{3}{|c|}{ Age at PD diagnosis } & \multicolumn{2}{|c|}{ Disease duration $^{b}$} \\
\hline & & & & & Male & Female & Mean & SD & MD & Mean & SD & MD & Mean & SD & MD & Mean & SD \\
\hline & \multirow[t]{2}{*}{ Kruger $^{a}$} & \multirow[t]{2}{*}{ Luxembourg } & Cases & 285 & 69.5 & 30.5 & 67.7 & 11.3 & & 60.1 & 12.8 & & 62.3 & 12.0 & 10 & 7.2 & 6.2 \\
\hline & & & Controls & 283 & 57.2 & 42.8 & 58.5 & 12.1 & & - & - & & - & - & & - & - \\
\hline & \multirow[t]{2}{*}{ Puschmanna } & \multirow[t]{2}{*}{ Sweden } & Cases & 50 & 70.0 & 30.0 & 69.0 & 10.4 & & 61.5 & 11.3 & & & & 49 & 7.4 & 4.8 \\
\hline & & & Controls & 105 & 29.5 & 70.5 & 66.7 & 8.9 & & - & - & & - & - & & - & - \\
\hline & \multirow[t]{2}{*}{ Stefanis/Simitsi ${ }^{a}$} & \multirow[t]{2}{*}{ Greece } & Cases & 174 & 62.1 & 37.9 & 67.7 & 13.3 & & 61.5 & 13.6 & & 61.9 & 12.7 & 44 & 6.2 & 6.3 \\
\hline & & & Controls & 178 & 36.0 & 64.0 & 67.0 & 9.6 & & - & - & & - & - & & - & - \\
\hline & \multirow[t]{2}{*}{ Tolosad $^{d}$} & \multirow[t]{2}{*}{ Spain } & Cases & 141 & 62.4 & 37.6 & 67.4 & 10.3 & & 60.4 & 11.1 & & & & 141 & 7.0 & 5.9 \\
\hline & & & Controls & 66 & 16.7 & 83.3 & 61.9 & 12.1 & 8 & - & - & & - & - & & - & - \\
\hline & \multirow[t]{2}{*}{ Valente } & \multirow[t]{2}{*}{ Italy } & Cases & 223 & 60.1 & 39.9 & 67.1 & 12.7 & 4 & 54.3 & 10.8 & 4 & 59.1 & 7.8 & 144 & 12.7 & 8.2 \\
\hline & & & Controls & 54 & 38.9 & 61.1 & 78.4 & 9.6 & & - & - & & - & - & & - & - \\
\hline & \multirow{2}{*}{ Wirdefeldt ${ }^{\mathrm{a}}$} & \multirow[t]{2}{*}{ Sweden } & Cases & 61 & 55.7 & 44.3 & 75.9 & 8.1 & & 66.8 & 9.9 & & & & 61 & 8.6 & 5.6 \\
\hline & & & Controls & 165 & 46.1 & 53.9 & 73.9 & 9.6 & & - & - & & - & - & & - & - \\
\hline & \multirow[t]{2}{*}{ Zimprich } & \multirow[t]{2}{*}{ Austria } & Cases & 500 & 63.0 & 37.0 & & & 500 & 59.1 & 11.2 & & & & 500 & & \\
\hline & & & Controls & 182 & 40.1 & 59.9 & & & 182 & - & - & & - & - & & - & - \\
\hline & \multirow[t]{2}{*}{ Total } & & Cases & 7,369 & & & & & & & & & & & & & \\
\hline & & & Controls & 7,018 & & & & & & & & & & & & & \\
\hline
\end{tabular}

MD, missing data; SD, standard deviation.

a Sites from the Geo-PD consortium.

${ }^{b}$ Duration disease = age at study - age at PD onset. Missing values are the same as those for age at study.

c For the Gasser/Sharma site, we excluded 1,000 samples overlapping with iPDGC (642 cases, 358 controls).

d For the Tolosa site, we excluded 137 samples of PD cases overlapping with iPDGC. 
Supplementary table 2: Statistical power to detect odds ratios comprised between 0.3 and 0.9 for two values of type-1 error in Mendelian randomization analyses in the Courage-PD consortium (7,369 cases, 7,018 controls).

\begin{tabular}{|c|c|c|c|c|c|c|c|c|c|c|c|c|c|c|c|}
\hline \multirow[b]{3}{*}{ Exposure } & \multirow[b]{3}{*}{$\mathbf{R}^{2}$} & \multicolumn{7}{|c|}{ Type-1 error=1.7\% } & \multicolumn{7}{|c|}{ Type-1 error=5\% } \\
\hline & & \multicolumn{7}{|c|}{ Odds ratio } & \multicolumn{7}{|c|}{ Odds ratio } \\
\hline & & 0.30 & 0.40 & 0.50 & 0.60 & 0.70 & 0.80 & 0.90 & 0.30 & 0.40 & 0.50 & 0.60 & 0.70 & 0.80 & 0.90 \\
\hline Smoking initiation & $2.95 \%$ & 1.00 & 1.00 & 1.00 & 1.00 & 0.91 & 0.47 & 0.10 & 1.00 & 1.00 & 1.00 & 1.00 & 0.96 & 0.64 & 0.19 \\
\hline Lifetime smoking index & $0.49 \%$ & 1.00 & 0.95 & 0.73 & 0.42 & 0.19 & 0.07 & 0.03 & 1.00 & 0.98 & 0.85 & 0.59 & 0.33 & 0.16 & 0.07 \\
\hline Alcohol drinking & $0.48 \%$ & 1.00 & 0.94 & 0.72 & 0.41 & 0.19 & 0.07 & 0.03 & 1.00 & 0.98 & 0.84 & 0.58 & 0.32 & 0.15 & 0.07 \\
\hline Coffee drinking & $0.21 \%$ & 0.88 & 0.60 & 0.33 & 0.17 & 0.08 & 0.04 & 0.02 & 0.95 & 0.75 & 0.50 & 0.30 & 0.17 & 0.09 & 0.06 \\
\hline
\end{tabular}

$\mathrm{R}^{2}$ is the sum of the proportion of the variance of the exposure explained by each individual genetic variants (Supplementary table 3 ).

Bold values are $\geq 0.80$.

Statistical power was computed according to Brion MJ et al. (Int J Epidemiol 2013;42:1497-1501). 


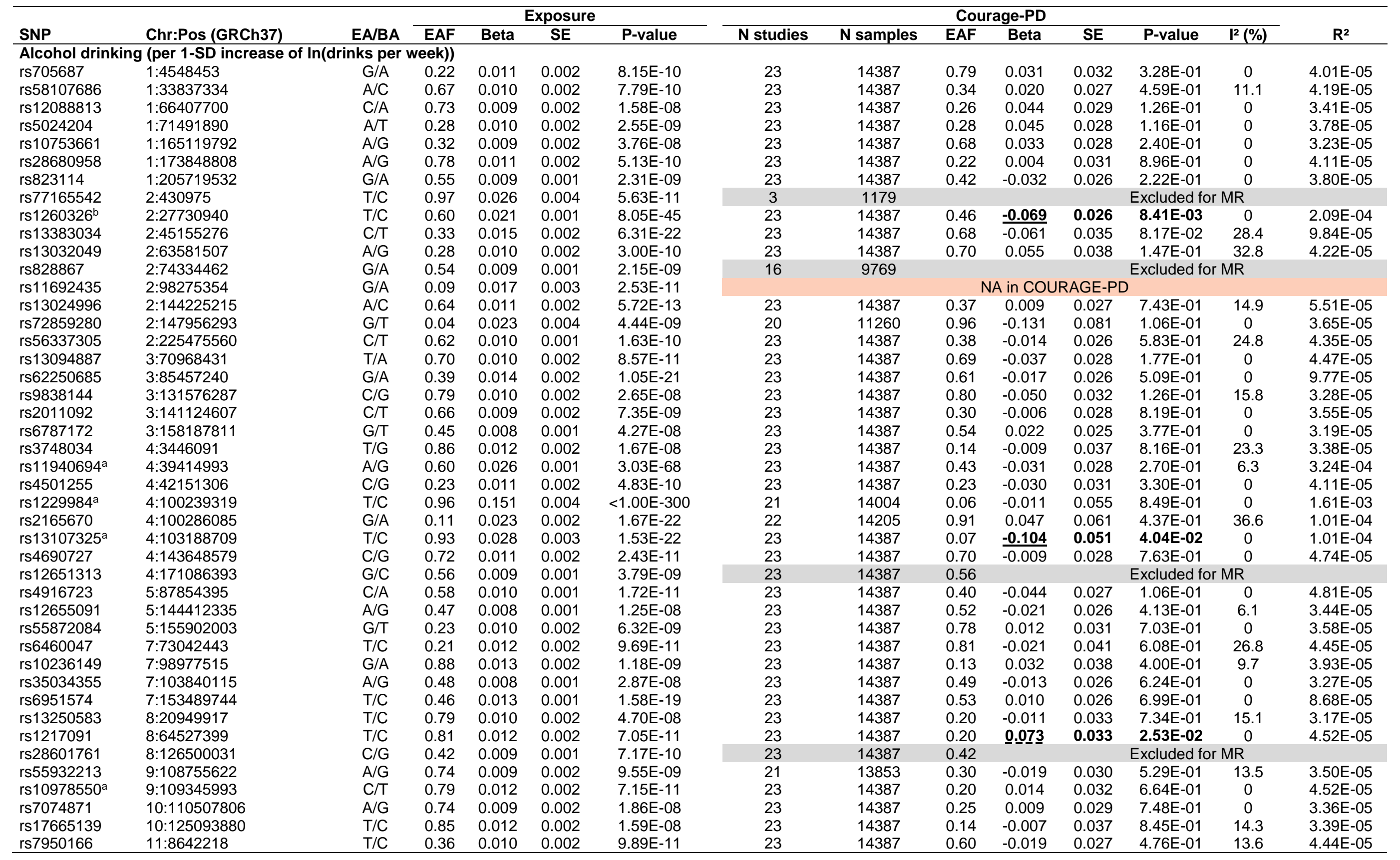




\begin{tabular}{|c|c|c|c|c|c|c|c|c|c|c|c|c|c|c|}
\hline \multirow[b]{2}{*}{ SNP } & \multirow[b]{2}{*}{ Chr:Pos (GRCh37) } & \multirow[b]{2}{*}{ EA/BA } & \multicolumn{4}{|c|}{ Exposure } & \multicolumn{7}{|c|}{ Courage-PD } & \multirow[b]{2}{*}{$\mathbf{R}^{2}$} \\
\hline & & & EAF & Beta & SE & P-value & N studies & N samples & EAF & Beta & SE & P-value & $\mathbf{I}^{2}(\%)$ & \\
\hline rs11030084 & $11: 27643725$ & $\mathrm{~T} / \mathrm{C}$ & 0.82 & 0.011 & 0.002 & $1.72 \mathrm{E}-08$ & 23 & 14387 & 0.20 & -0.035 & 0.032 & $2.82 \mathrm{E}-01$ & 0 & $3.38 \mathrm{E}-05$ \\
\hline rs56030824 & $11: 47397353$ & $A / G$ & 0.68 & 0.012 & 0.002 & $1.15 \mathrm{E}-13$ & 23 & 14387 & 0.32 & 0.006 & 0.027 & 8.26E-01 & 24.9 & $5.88 \mathrm{E}-05$ \\
\hline rs10750025a & $11: 113424042$ & $\mathrm{C} / \mathrm{T}$ & 0.69 & 0.010 & 0.002 & $4.89 \mathrm{E}-11$ & 23 & 14387 & 0.34 & -0.004 & 0.027 & 8.85E-01 & 0 & $4.59 \mathrm{E}-05$ \\
\hline rs4938230 & $11: 116075001$ & $\mathrm{C} / \mathrm{A}$ & 0.84 & 0.013 & 0.002 & $1.48 \mathrm{E}-10$ & 14 & 6683 & \multicolumn{6}{|c|}{ Excluded for MR } \\
\hline rs682011 a & $11: 121544285$ & $\mathrm{~T} / \mathrm{C}$ & 0.56 & 0.008 & 0.001 & $2.22 \mathrm{E}-08$ & 23 & 14387 & 0.46 & -0.021 & 0.026 & $4.21 \mathrm{E}-01$ & 0 & 3.33E-05 \\
\hline rs12795042 & $11: 133658168$ & $\mathrm{C} / \mathrm{A}$ & 0.38 & 0.008 & 0.002 & $3.25 \mathrm{E}-08$ & 23 & 14387 & 0.58 & -0.012 & 0.036 & 7.33E-01 & 31.3 & $3.25 \mathrm{E}-05$ \\
\hline rs3809162 & $12: 54674235$ & $\mathrm{~A} / \mathrm{G}$ & 0.40 & 0.009 & 0.001 & 1.19E-09 & 23 & 14387 & 0.64 & -0.014 & 0.027 & $6.00 \mathrm{E}-01$ & 8.5 & 3.93E-05 \\
\hline rs10506274 & $12: 81601464$ & $\mathrm{~T} / \mathrm{G}$ & 0.52 & 0.009 & 0.001 & $5.78 \mathrm{E}-10$ & 23 & 14387 & 0.48 & 0.017 & 0.025 & 5.13E-01 & 19.7 & $4.08 \mathrm{E}-05$ \\
\hline rs4842786 & $12: 92170791$ & $A / G$ & 0.42 & 0.009 & 0.001 & 2.73E-09 & 23 & 14387 & 0.56 & 0.000 & 0.027 & $9.99 \mathrm{E}-01$ & 22.8 & 3.76E-05 \\
\hline rs500321 & 13:27124360 & $\mathrm{T} / \mathrm{A}$ & 0.26 & 0.010 & 0.002 & 4.92E-09 & 23 & 14387 & 0.28 & 0.009 & 0.029 & 7.70E-01 & 11.5 & 3.63E-05 \\
\hline rs1123285 & $14: 57274519$ & $\mathrm{G} / \mathrm{C}$ & 0.66 & 0.009 & 0.002 & $8.14 \mathrm{E}-09$ & 23 & 14387 & 0.66 & -0.041 & 0.027 & 1.35E-01 & 10.4 & 3.53E-05 \\
\hline rs28929474 & $14: 94844947$ & $\mathrm{~T} / \mathrm{C}$ & 0.98 & 0.037 & 0.005 & $1.34 \mathrm{E}-11$ & 16 & 9567 & \multicolumn{6}{|c|}{ Excluded for MR } \\
\hline rs2472297 & $15: 75027880$ & $\mathrm{C} / \mathrm{T}$ & 0.25 & 0.011 & 0.002 & $3.10 \mathrm{E}-10$ & 23 & 14387 & 0.81 & -0.032 & 0.033 & 3.30E-01 & 0 & 4.21E-05 \\
\hline rs12907323 & $15: 86796012$ & $\mathrm{~A} / \mathrm{G}$ & 0.41 & 0.008 & 0.001 & 9.93E-09 & 23 & 14387 & 0.56 & 0.010 & 0.026 & $7.11 \mathrm{E}-01$ & 2 & $3.50 \mathrm{E}-05$ \\
\hline rs $17177078^{a}$ & $16: 24810681$ & $\mathrm{~T} / \mathrm{C}$ & 0.94 & 0.022 & 0.003 & $1.27 \mathrm{E}-13$ & 23 & 14387 & 0.08 & -0.027 & 0.048 & $5.78 \mathrm{E}-01$ & 0 & $5.84 \mathrm{E}-05$ \\
\hline rs378421 & $16: 28754684$ & $\mathrm{~A} / \mathrm{G}$ & 0.60 & 0.011 & 0.001 & $4.83 E-14$ & 23 & 14387 & 0.38 & -0.030 & 0.027 & $2.56 \mathrm{E}-01$ & 8.6 & $6.05 \mathrm{E}-05$ \\
\hline rs62044525 & $16: 64872590$ & $\mathrm{G} / \mathrm{C}$ & 0.82 & 0.012 & 0.002 & $1.03 \mathrm{E}-10$ & 23 & 14387 & 0.82 & 0.079 & 0.033 & 1.77E-02 & 0 & 4.45E-05 \\
\hline rs1104608 & $16: 73912588$ & $\mathrm{C} / \mathrm{G}$ & 0.58 & 0.011 & 0.001 & $1.05 E-13$ & 11 & 5990 & \multicolumn{6}{|c|}{ Excluded for MR } \\
\hline rs4548913 & 17:2209888 & $A / G$ & 0.37 & 0.008 & 0.002 & $3.11 \mathrm{E}-08$ & 23 & 14387 & 0.60 & -0.014 & 0.027 & 5.91E-01 & 9.7 & $3.25 \mathrm{E}-05$ \\
\hline rs3803800a & $17: 7462969$ & $A / G$ & 0.79 & 0.011 & 0.002 & $1.50 \mathrm{E}-10$ & 23 & 14387 & 0.20 & 0.005 & 0.032 & 8.82E-01 & 0 & 4.36E-05 \\
\hline rs2854334 & $17: 29715500$ & $\mathrm{~A} / \mathrm{G}$ & 0.62 & 0.009 & 0.001 & $7.51 \mathrm{E}-10$ & 20 & 13362 & 0.39 & 0.035 & 0.030 & 2.38E-01 & 0 & 4.03E-05 \\
\hline rs10438820 & $17: 78524597$ & $\mathrm{C} / \mathrm{T}$ & 0.70 & 0.009 & 0.002 & $1.76 \mathrm{E}-08$ & 23 & 14387 & 0.30 & 0.029 & 0.028 & 3.03E-01 & 6.3 & 3.37E-05 \\
\hline rs9950000 & $18: 53052169$ & $\mathrm{~T} / \mathrm{C}$ & 0.60 & 0.009 & 0.001 & $9.38 \mathrm{E}-10$ & 23 & 14387 & 0.40 & -0.009 & 0.026 & 7.41E-01 & 0 & 3.97E-05 \\
\hline rs4092465 & $18: 55080437$ & $G / A$ & 0.36 & 0.008 & 0.002 & 4.39E-08 & \multicolumn{8}{|c|}{ NA in COURAGE-PD } \\
\hline rs281379 & $19: 49214274$ & $\mathrm{G} / \mathrm{A}$ & 0.51 & 0.014 & 0.001 & $4.91 \mathrm{E}-21$ & 23 & 14387 & 0.54 & 0.016 & 0.026 & 5.43E-01 & 0 & $9.41 \mathrm{E}-05$ \\
\hline rs4815364 & $20: 25035711$ & $\mathrm{G} / \mathrm{A}$ & 0.62 & 0.009 & 0.001 & $1.02 E-08$ & 23 & 14387 & 0.37 & 0.044 & 0.027 & $1.04 \mathrm{E}-01$ & 6.3 & $3.48 \mathrm{E}-05$ \\
\hline rs9607814 & $22: 41946519$ & $\mathrm{~A} / \mathrm{C}$ & 0.80 & 0.010 & 0.002 & 4.31E-08 & 23 & 14387 & 0.21 & $\underline{-0.121}$ & 0.032 & 1.83E-04 & 4.2 & 3.32E-05 \\
\hline \multicolumn{15}{|c|}{ Coffee drinking (per In(cups per day)) } \\
\hline rs574367 & $1: 177873210$ & $\mathrm{~T} / \mathrm{G}$ & 0.21 & 0.010 & 0.002 & 8.06E-09 & 23 & 14387 & 0.18 & -0.139 & 0.051 & 6.63E-03 & 47 & 3.32E-05 \\
\hline rs10865548 & $2: 631606$ & $\mathrm{G} / \mathrm{A}$ & 0.83 & 0.015 & 0.002 & $4.46 \mathrm{E}-15$ & 23 & 14387 & 0.80 & $\overline{0.014}$ & 0.033 & $6.77 \mathrm{E}-01$ & 10.4 & $6.35 \mathrm{E}-05$ \\
\hline rs $1260326^{b}$ & $2: 27730940$ & $\mathrm{C} / \mathrm{T}$ & 0.61 & 0.014 & 0.002 & $2.62 E-19$ & 23 & 14387 & 0.54 & 0.069 & 0.026 & 8.41E-03 & 0 & 9.33E-05 \\
\hline rs4410790 & $7: 17284577$ & $\mathrm{C} / \mathrm{T}$ & 0.63 & 0.039 & 0.002 & $5.59 \mathrm{E}-141$ & 23 & 14387 & 0.61 & -0.009 & 0.027 & $7.22 \mathrm{E}-01$ & 3.6 & 7.09E-04 \\
\hline rs34060476 & 7:73037956 & $G / A$ & 0.13 & 0.019 & 0.002 & $5.06 \mathrm{E}-18$ & 23 & 14387 & 0.11 & 0.045 & 0.041 & $2.72 \mathrm{E}-01$ & 15.6 & 8.17E-05 \\
\hline rs1057868 & 7:75615006 & $\mathrm{T} / \mathrm{C}$ & 0.29 & 0.020 & 0.002 & $5.26 \mathrm{E}-33$ & 23 & 14387 & 0.28 & 0.041 & 0.028 & $1.48 \mathrm{E}-01$ & 0 & 1.65E-04 \\
\hline rs597045 & $11: 56272114$ & $\mathrm{~A} / \mathrm{T}$ & 0.70 & 0.011 & 0.002 & $6.62 E-11$ & 23 & 14387 & 0.70 & -0.035 & 0.037 & $3.42 E-01$ & 33.2 & 5.08E-05 \\
\hline rs1956218 & $14: 33075243$ & $\mathrm{G} / \mathrm{A}$ & 0.56 & 0.008 & 0.002 & $3.62 E-08$ & 23 & 14387 & 0.53 & -0.027 & 0.026 & $2.96 \mathrm{E}-01$ & 0 & $3.15 \mathrm{E}-05$ \\
\hline rs2472297 & $15: 75027880$ & $\mathrm{~T} / \mathrm{C}$ & 0.26 & 0.044 & 0.002 & $5.19 \mathrm{E}-155$ & 23 & 14387 & 0.19 & 0.032 & 0.033 & $3.30 \mathrm{E}-01$ & 0 & 7.45E-04 \\
\hline rs66723169 & $18: 57808978$ & $A / C$ & 0.23 & 0.015 & 0.002 & $9.88 \mathrm{E}-17$ & 23 & 14387 & 0.23 & -0.019 & 0.031 & 5.47E-01 & 9.5 & 7.97E-05 \\
\hline rs2330783 & $22: 24747031$ & $\mathrm{G} / \mathrm{T}$ & 0.99 & 0.044 & 0.006 & $1.57 \mathrm{E}-12$ & 18 & 11562 & 0.98 & 0.168 & 0.119 & $1.57 \mathrm{E}-01$ & 4.6 & 3.83E-05 \\
\hline \multicolumn{15}{|c|}{ Lifetime smoking index } \\
\hline rs1193237 & $1: 7526486$ & $\mathrm{C} / \mathrm{G}$ & 0.56 & 0.008 & 0.001 & $2.80 \mathrm{E}-08$ & 23 & 14387 & 0.57 & \multicolumn{5}{|c|}{ Excluded for MR } \\
\hline rs4949465 & 1:32178489 & $\mathrm{C} / \mathrm{T}$ & 0.13 & 0.012 & 0.002 & $1.70 \mathrm{E}-08$ & 23 & 14387 & 0.12 & 0.002 & 0.040 & $9.59 \mathrm{E}-01$ & 0 & 3.06E-05 \\
\hline rs549845 & $1: 44076469$ & $\mathrm{G} / \mathrm{A}$ & 0.30 & 0.011 & 0.002 & $8.30 \mathrm{E}-14$ & 23 & 14387 & 0.33 & -0.054 & 0.028 & $5.20 \mathrm{E}-02$ & 23.8 & 5.34E-05 \\
\hline rs1933270 & $1: 49977965$ & $\mathrm{~T} / \mathrm{G}$ & 0.36 & 0.009 & 0.001 & $1.50 \mathrm{E}-10$ & 23 & 14387 & 0.37 & $\underline{0.05} \underline{7}$ & 0.027 & 3.23E-02 & 0 & 3.93E-05 \\
\hline rs7528604 & $1: 66407352$ & $\mathrm{G} / \mathrm{A}$ & 0.57 & 0.010 & 0.001 & $5.70 \mathrm{E}-12$ & 23 & 14387 & 0.56 & -0.002 & 0.026 & $9.32 \mathrm{E}-01$ & 0.4 & $4.58 \mathrm{E}-05$ \\
\hline rs11210229 & $1: 73860028$ & $A / G$ & 0.38 & 0.012 & 0.001 & $2.00 \mathrm{E}-16$ & 23 & 14387 & 0.45 & -0.025 & 0.026 & $3.48 \mathrm{E}-01$ & 17.4 & $6.48 \mathrm{E}-05$ \\
\hline
\end{tabular}




\begin{tabular}{|c|c|c|c|c|c|c|c|c|c|c|c|c|c|c|}
\hline \multirow[b]{2}{*}{ SNP } & \multirow[b]{2}{*}{ Chr:Pos (GRCh37) } & \multirow[b]{2}{*}{ EA/BA } & \multicolumn{4}{|c|}{ Exposure } & \multicolumn{7}{|c|}{ Courage-PD } & \multirow[b]{2}{*}{$\mathbf{R}^{2}$} \\
\hline & & & EAF & Beta & SE & P-value & N studies & N samples & EAF & Beta & SE & P-value & $\left.\right|^{2}(\%)$ & \\
\hline rs7553348 & $1: 75005067$ & $G / A$ & 0.44 & 0.010 & 0.001 & $5.20 \mathrm{E}-12$ & 23 & 14387 & 0.44 & 0.009 & 0.026 & 7.44E-01 & 4.8 & 4.57E-05 \\
\hline rs10922907 & $1: 91193049$ & $\mathrm{~A} / \mathrm{T}$ & 0.45 & 0.010 & 0.001 & $3.00 \mathrm{E}-13$ & 23 & 14387 & 0.48 & \multicolumn{5}{|c|}{ Excluded for MR } \\
\hline rs1931263 & $1: 96175101$ & $T / G$ & 0.49 & 0.008 & 0.001 & $4.00 \mathrm{E}-08$ & 23 & 14387 & 0.50 & -0.026 & 0.026 & $3.16 \mathrm{E}-01$ & 2.8 & 2.89E-05 \\
\hline rs7519626 & $1: 99514554$ & $\mathrm{C} / \mathrm{T}$ & 0.32 & 0.008 & 0.001 & $1.20 \mathrm{E}-08$ & 23 & 14387 & 0.36 & 0.005 & 0.028 & 8.64E-01 & 12 & $3.10 \mathrm{E}-05$ \\
\hline rs9435340 & $1: 107593201$ & T/A & 0.34 & 0.008 & 0.001 & $1.20 \mathrm{E}-08$ & 23 & 14387 & 0.35 & 0.013 & 0.028 & 6.37E-01 & 0 & 3.15E-05 \\
\hline rs10918701 & $1: 162090536$ & $\mathrm{G} / \mathrm{A}$ & 0.37 & 0.008 & 0.001 & 2.10E-08 & 23 & 14387 & 0.40 & -0.017 & 0.026 & $5.25 E-01$ & 17 & $3.01 \mathrm{E}-05$ \\
\hline rs2867112 & $2: 651349$ & $\mathrm{~T} / \mathrm{G}$ & 0.83 & 0.015 & 0.002 & $4.80 \mathrm{E}-15$ & 23 & 14387 & 0.82 & 0.015 & 0.034 & 6.59E-01 & 5.9 & 6.03E-05 \\
\hline rs6741228 & $2: 22548774$ & $\mathrm{~T} / \mathrm{C}$ & 0.43 & 0.008 & 0.001 & $1.60 \mathrm{E}-08$ & 23 & 14387 & 0.44 & -0.015 & 0.026 & 5.56E-01 & 10.9 & 3.09E-05 \\
\hline rs62135536 & $2: 44326028$ & $\mathrm{C} / \mathrm{T}$ & 0.97 & 0.024 & 0.004 & 8.00E-10 & 18 & 13065 & 0.97 & -0.006 & 0.086 & $9.49 \mathrm{E}-01$ & 13.6 & 3.64E-05 \\
\hline rs7569203 & $2: 45154418$ & $\mathrm{C} / \mathrm{A}$ & 0.31 & 0.011 & 0.002 & $7.40 \mathrm{E}-13$ & 23 & 14387 & 0.32 & 0.058 & 0.035 & $9.40 \mathrm{E}-02$ & 27.7 & 4.96E-05 \\
\hline rs13016665 & 2:57995348 & $A / C$ & 0.42 & 0.008 & 0.001 & 1.80E-09 & 23 & 14387 & 0.42 & 0.041 & 0.027 & 1.19E-01 & 0 & 3.52E-05 \\
\hline rs $4671357^{a}$ & 2:60136176 & $\mathrm{C} / \mathrm{T}$ & 0.48 & 0.009 & 0.001 & $1.10 \mathrm{E}-11$ & 23 & 14386 & 0.47 & -0.018 & 0.026 & 4.82E-01 & 0 & $4.45 \mathrm{E}-05$ \\
\hline rs359243 & $2: 60475509$ & $\mathrm{C} / \mathrm{T}$ & 0.61 & 0.009 & 0.001 & $9.50 \mathrm{E}-10$ & 23 & 14387 & 0.57 & -0.013 & 0.035 & 7.03E-01 & 32.1 & 3.63E-05 \\
\hline rs2678670 & $2: 104469564$ & $A / T$ & 0.49 & 0.009 & 0.001 & 3.10E-10 & 23 & 14387 & 0.50 & \multicolumn{5}{|c|}{ Excluded for MR } \\
\hline rs62155874 & $2: 105973094$ & $\mathrm{G} / \mathrm{A}$ & 0.13 & 0.017 & 0.002 & $5.20 \mathrm{E}-16$ & 23 & 14387 & 0.12 & -0.023 & 0.039 & 5.63E-01 & 0 & 6.32E-05 \\
\hline rs3811038 & 2:113240183 & $\mathrm{C} / \mathrm{T}$ & 0.28 & 0.010 & 0.002 & $8.90 \mathrm{E}-10$ & 23 & 14387 & 0.28 & -0.004 & 0.029 & 8.90E-01 & 9.1 & 3.64E-05 \\
\hline rs2890772 & $2: 146175106$ & $\mathrm{~T} / \mathrm{G}$ & 0.59 & 0.014 & 0.001 & 2.10E-22 & 23 & 14387 & 0.55 & 0.009 & 0.026 & 7.20E-01 & 0 & $9.10 \mathrm{E}-05$ \\
\hline rs62175972 & $2: 161362830$ & $\mathrm{~T} / \mathrm{C}$ & 0.97 & 0.022 & 0.004 & $1.70 \mathrm{E}-08$ & 23 & 14387 & 0.96 & 0.050 & 0.069 & 4.66E-01 & 0 & 3.11E-05 \\
\hline rs3769949 & $2: 166199284$ & $A / T$ & 0.47 & 0.008 & 0.001 & 2.50E-09 & 23 & 14387 & 0.47 & \multicolumn{5}{|c|}{ Excluded for MR } \\
\hline rs13009008 & $2: 174043233$ & $A / G$ & 0.33 & 0.009 & 0.001 & 4.60E-09 & 23 & 14387 & 0.35 & 0.045 & 0.027 & 9.27E-02 & 0 & $3.28 \mathrm{E}-05$ \\
\hline rs4473348 & 2:182073742 & $\mathrm{T} / \mathrm{A}$ & 0.75 & 0.010 & 0.002 & $6.40 \mathrm{E}-11$ & 23 & 14387 & 0.76 & -0.037 & 0.030 & $2.21 \mathrm{E}-01$ & 13.6 & 4.08E-05 \\
\hline rs12623702 & $2: 202885506$ & $\mathrm{G} / \mathrm{A}$ & 0.39 & 0.010 & 0.001 & 7.70E-12 & 23 & 14387 & 0.37 & -0.048 & 0.027 & 6.88E-02 & 0 & 4.53E-05 \\
\hline rs6779302 & 3:16859710 & $T / G$ & 0.37 & 0.009 & 0.001 & $1.20 \mathrm{E}-09$ & 23 & 14387 & 0.35 & 0.041 & 0.027 & $1.25 \mathrm{E}-01$ & 0 & 3.56E-05 \\
\hline rs6778080a & 3:49317338 & $\mathrm{T} / \mathrm{C}$ & 0.27 & 0.011 & 0.002 & $1.30 \mathrm{E}-12$ & 23 & 14387 & 0.27 & -0.018 & 0.030 & 5.39E-01 & 2.8 & 4.84E-05 \\
\hline rs775758 & $3: 77582005$ & $A / T$ & 0.43 & 0.008 & 0.001 & $1.10 \mathrm{E}-08$ & 23 & 14387 & 0.43 & \multicolumn{5}{|c|}{ Excluded for MR } \\
\hline rs421983 & 3:84892866 & $\mathrm{T} / \mathrm{C}$ & 0.52 & 0.009 & 0.001 & $3.30 \mathrm{E}-10$ & 23 & 14387 & 0.50 & 0.004 & 0.025 & 8.64E-01 & 14.2 & 3.79E-05 \\
\hline rs326341 & 3:107811142 & $G / A$ & 0.52 & 0.009 & 0.001 & $1.20 \mathrm{E}-11$ & 23 & 14387 & 0.55 & -0.012 & 0.026 & $6.48 \mathrm{E}-01$ & 0 & $4.44 \mathrm{E}-05$ \\
\hline rs73220544 & 3:131074511 & $\mathrm{C} / \mathrm{A}$ & 0.16 & 0.011 & 0.002 & $1.50 \mathrm{E}-08$ & 21 & 13998 & 0.18 & -0.062 & 0.037 & $9.73 \mathrm{E}-02$ & 0 & 3.11E-05 \\
\hline rs9842947 & 3:157412246 & $\mathrm{T} / \mathrm{C}$ & 0.67 & 0.009 & 0.001 & 3.10E-09 & 23 & 14387 & 0.70 & 0.033 & 0.029 & $2.51 \mathrm{E}-01$ & 0 & 3.38E-05 \\
\hline rs624833a & $4: 2881256$ & $T / G$ & 0.69 & 0.009 & 0.002 & $6.60 \mathrm{E}-10$ & 23 & 14387 & 0.69 & $\underline{-0.076}$ & 0.031 & $1.30 \mathrm{E}-02$ & 10.7 & 3.66E-05 \\
\hline rs61796681 & $4: 23678196$ & $T / A$ & 0.09 & 0.013 & 0.002 & $4.20 \mathrm{E}-08$ & 23 & 14387 & 0.07 & $\overline{0.025}$ & 0.049 & $6.17 \mathrm{E}-01$ & 6.7 & 2.88E-05 \\
\hline rs317021 & $4: 35418368$ & $\mathrm{~A} / \mathrm{T}$ & 0.19 & 0.012 & 0.002 & $1.10 \mathrm{E}-10$ & 23 & 14387 & 0.16 & 0.030 & 0.035 & 3.96E-01 & 15.1 & 4.05E-05 \\
\hline rs72678864 & $4: 112422145$ & $\mathrm{G} / \mathrm{A}$ & 0.83 & 0.012 & 0.002 & $1.60 \mathrm{E}-11$ & 23 & 14387 & 0.85 & 0.025 & 0.037 & 4.88E-01 & 0 & 4.36E-05 \\
\hline rs17576594 & $4: 147952241$ & $\mathrm{G} / \mathrm{A}$ & 0.72 & 0.011 & 0.002 & $1.70 \mathrm{E}-12$ & 23 & 14387 & 0.74 & -0.044 & 0.029 & $1.27 \mathrm{E}-01$ & 0 & 4.80E-05 \\
\hline rs11948770 & 5:13246336 & $\mathrm{C} / \mathrm{T}$ & 0.23 & 0.010 & 0.002 & $4.90 \mathrm{E}-10$ & 23 & 14387 & 0.23 & -0.045 & 0.030 & 1.38E-01 & 23.6 & 3.73E-05 \\
\hline rs71627581 & $5: 43161351$ & $\mathrm{G} / \mathrm{A}$ & 0.89 & 0.013 & 0.002 & 1.60E-09 & 15 & 8384 & & \multicolumn{5}{|c|}{ Excluded for MR } \\
\hline rs10052591 & $5: 50812738$ & $\mathrm{~T} / \mathrm{C}$ & 0.57 & 0.008 & 0.001 & 2.10E-09 & 23 & 14387 & 0.57 & 0.026 & 0.026 & 3.10E-01 & 0 & 3.45E-05 \\
\hline rs2080870 & $5: 60388313$ & $A / T$ & 0.26 & 0.009 & 0.002 & 4.90E-08 & 23 & 14387 & 0.25 & $\underline{0.062}$ & 0.030 & $3.68 \mathrm{E}-02$ & 0 & $2.85 \mathrm{E}-05$ \\
\hline rs $4571506^{a}$ & 5:87756918 & $\mathrm{C} / \mathrm{T}$ & 0.54 & 0.008 & 0.001 & $1.50 \mathrm{E}-08$ & 23 & 14385 & 0.51 & $\underline{-0.053}$ & 0.026 & 4.10E-02 & 0 & 3.08E-05 \\
\hline rs4957528 & $5: 106420589$ & $\mathrm{C} / \mathrm{A}$ & 0.79 & 0.010 & 0.002 & 4.20E-09 & 10 & 5308 & \multicolumn{6}{|c|}{ Excluded for MR } \\
\hline rs329120a & $5: 133861756$ & $\mathrm{C} / \mathrm{T}$ & 0.58 & 0.010 & 0.001 & $6.30 \mathrm{E}-12$ & 23 & 14387 & 0.57 & -0.045 & 0.026 & 8.41E-02 & 0 & 4.54E-05 \\
\hline rs986391 & 5:166993972 & $\mathrm{G} / \mathrm{A}$ & 0.37 & 0.011 & 0.001 & $9.40 \mathrm{E}-15$ & 23 & 14387 & 0.38 & -0.020 & 0.027 & 4.73E-01 & 0 & $5.76 \mathrm{E}-05$ \\
\hline rs13153393 & $5: 167604213$ & $\mathrm{G} / \mathrm{A}$ & 0.12 & 0.014 & 0.002 & $2.50 \mathrm{E}-10$ & 23 & 14387 & 0.11 & 0.054 & 0.041 & $1.88 \mathrm{E}-01$ & 10.7 & 3.88E-05 \\
\hline rs245774 & $5: 170530930$ & $\mathrm{G} / \mathrm{A}$ & 0.73 & 0.009 & 0.002 & 7.40E-09 & 23 & 14387 & 0.71 & -0.053 & 0.029 & 6.81E-02 & 0 & 3.22E-05 \\
\hline rs6935954 & $6: 26255451$ & $A / G$ & 0.42 & 0.010 & 0.001 & 8.20E-12 & 23 & 14387 & 0.39 & 0.028 & 0.033 & $4.01 \mathrm{E}-01$ & 25.5 & 4.48E-05 \\
\hline rs2254710 & $6: 37477000$ & $\mathrm{C} / \mathrm{A}$ & 0.24 & 0.009 & 0.002 & $3.50 \mathrm{E}-08$ & 23 & 14387 & 0.23 & 0.028 & 0.042 & 5.05E-01 & 33.1 & 2.92E-05 \\
\hline rs2894808 & $6: 52861990$ & $\mathrm{~A} / \mathrm{T}$ & 0.08 & 0.015 & 0.003 & 3.50E-09 & 23 & 14387 & 0.10 & 0.007 & 0.044 & 8.70E-01 & 0 & 3.36E-05 \\
\hline rs12202536 & $6: 67475273$ & $\mathrm{G} / \mathrm{A}$ & 0.49 & 0.008 & 0.001 & 2.80E-09 & 23 & 14387 & 0.46 & -0.068 & 0.026 & 8.41E-03 & 20.2 & 3.39E-05 \\
\hline
\end{tabular}




\begin{tabular}{|c|c|c|c|c|c|c|c|c|c|c|c|c|c|c|}
\hline \multirow[b]{2}{*}{ SNP } & \multirow[b]{2}{*}{ Chr:Pos (GRCh37) } & \multirow[b]{2}{*}{ EA/BA } & \multicolumn{4}{|c|}{ Exposure } & \multicolumn{7}{|c|}{ Courage-PD } & \multirow[b]{2}{*}{$\mathbf{R}^{2}$} \\
\hline & & & EAF & Beta & SE & P-value & N studies & N samples & EAF & Beta & SE & P-value & $\mathbf{I}^{2}(\%)$ & \\
\hline rs7766610 & $6: 111707821$ & $\mathrm{C} / \mathrm{A}$ & 0.18 & 0.013 & 0.002 & $2.20 \mathrm{E}-12$ & 23 & 14387 & 0.19 & -0.058 & 0.043 & $1.84 \mathrm{E}-01$ & 29.6 & 4.73E-05 \\
\hline rs1922018 & $7: 3560401$ & $\mathrm{C} / \mathrm{T}$ & 0.36 & 0.010 & 0.001 & $3.00 \mathrm{E}-12$ & 23 & 14387 & 0.35 & -0.014 & 0.027 & $6.11 \mathrm{E}-01$ & 0 & 4.66E-05 \\
\hline rs10226228 & 7:32315613 & $G / A$ & 0.37 & 0.011 & 0.001 & $2.00 \mathrm{E}-15$ & 23 & 14387 & 0.36 & -0.034 & 0.027 & 2.04E-01 & 0 & 6.07E-05 \\
\hline rs11768481 & $7: 96629103$ & $\mathrm{C} / \mathrm{A}$ & 0.67 & 0.009 & 0.001 & $9.90 \mathrm{E}-10$ & 5 & 3107 & \multicolumn{6}{|c|}{ Excluded for MR } \\
\hline rs6962772 & $7: 99081730$ & $A / G$ & 0.85 & 0.011 & 0.002 & 7.80E-09 & 23 & 14387 & 0.85 & -0.012 & 0.036 & 7.28E-01 & 0 & $3.20 \mathrm{E}-05$ \\
\hline rs10282292 & 7:111092478 & $\mathrm{C} / \mathrm{T}$ & 0.36 & 0.009 & 0.001 & $5.90 \mathrm{E}-10$ & 23 & 14386 & 0.37 & 0.019 & 0.027 & 4.73E-01 & 0 & $3.71 \mathrm{E}-05$ \\
\hline rs2401924 & 7:115057862 & $\mathrm{G} / \mathrm{C}$ & 0.50 & 0.011 & 0.001 & $2.70 \mathrm{E}-14$ & 23 & 14387 & 0.51 & \multicolumn{5}{|c|}{ Excluded for MR } \\
\hline rs7807019 & 7:117543063 & $G / A$ & 0.46 & 0.010 & 0.001 & $6.70 \mathrm{E}-14$ & 23 & 14387 & 0.45 & 0.020 & 0.026 & 4.32E-01 & 5.5 & 5.39E-05 \\
\hline rs6957896a & 7:132309592 & $\mathrm{T} / \mathrm{C}$ & 0.50 & 0.008 & 0.001 & $4.50 \mathrm{E}-08$ & 22 & 13529 & 0.50 & -0.039 & 0.035 & 2.67E-01 & 32 & $2.88 \mathrm{E}-05$ \\
\hline rs4731925 & $7: 132664757$ & $\mathrm{~T} / \mathrm{C}$ & 0.68 & 0.008 & 0.001 & $2.60 \mathrm{E}-08$ & 23 & 14387 & 0.69 & -0.035 & 0.028 & $2.06 \mathrm{E}-01$ & 0 & 2.97E-05 \\
\hline rs35169606 & 8:9604066 & $T / G$ & 0.61 & 0.009 & 0.001 & $1.20 \mathrm{E}-09$ & 16 & 9769 & \multicolumn{6}{|c|}{ Excluded for MR } \\
\hline rs11783093 & 8:27425349 & $\mathrm{C} / \mathrm{T}$ & 0.84 & 0.016 & 0.002 & $1.20 \mathrm{E}-16$ & 23 & 14387 & 0.84 & -0.021 & 0.035 & 5.46E-01 & 21.5 & 6.67E-05 \\
\hline rs2062882a & 8:91839576 & $A / G$ & 0.41 & 0.008 & 0.001 & 1.10E-08 & 23 & 14387 & 0.43 & -0.022 & 0.026 & 3.87E-01 & 0 & 3.19E-05 \\
\hline rs72674867 & 8:95578201 & $\mathrm{A} / \mathrm{T}$ & 0.76 & 0.009 & 0.002 & $3.80 \mathrm{E}-08$ & 23 & 14387 & 0.73 & 0.015 & 0.029 & $6.04 \mathrm{E}-01$ & 15.3 & $2.91 \mathrm{E}-05$ \\
\hline rs4543592 & 9:3014254 & $\mathrm{C} / \mathrm{T}$ & 0.48 & 0.009 & 0.001 & $4.50 \mathrm{E}-10$ & 23 & 14387 & 0.48 & -0.026 & 0.026 & $3.25 \mathrm{E}-01$ & 17.6 & $3.75 \mathrm{E}-05$ \\
\hline rs7039819 & $9: 82430418$ & $G / A$ & 0.43 & 0.009 & 0.001 & $5.10 \mathrm{E}-10$ & 23 & 14387 & 0.42 & -0.009 & 0.027 & 7.52E-01 & 0 & 3.73E-05 \\
\hline rs1246265 & $9: 86761745$ & $\mathrm{C} / \mathrm{T}$ & 0.70 & 0.009 & 0.002 & 4.20E-09 & 23 & 14387 & 0.69 & -0.020 & 0.035 & 5.77E-01 & 26.2 & 3.33E-05 \\
\hline rs1221148 & $9: 122046875$ & $C / G$ & 0.59 & 0.009 & 0.001 & $7.30 \mathrm{E}-11$ & 23 & 14387 & 0.61 & 0.026 & 0.027 & 3.38E-01 & 0 & 4.07E-05 \\
\hline rs13296519 & $9: 128471924$ & $\mathrm{~T} / \mathrm{G}$ & 0.39 & 0.010 & 0.001 & $8.10 \mathrm{E}-12$ & 23 & 14387 & 0.39 & -0.024 & 0.027 & 3.56E-01 & 10 & 4.49E-05 \\
\hline rs113382419 & 9:136463019 & $A / C$ & 0.11 & 0.028 & 0.002 & $3.00 \mathrm{E}-37$ & 23 & 14387 & 0.10 & -0.017 & 0.044 & 6.92E-01 & 0 & 1.57E-04 \\
\hline rs11255908 & $10: 8802912$ & $\mathrm{G} / \mathrm{T}$ & 0.26 & 0.010 & 0.002 & $2.30 \mathrm{E}-10$ & 23 & 14387 & 0.26 & -0.015 & 0.029 & $6.13 \mathrm{E}-01$ & 0 & 3.87E-05 \\
\hline rs2675638 ${ }^{a}$ & $10: 63576286$ & $\mathrm{G} / \mathrm{A}$ & 0.58 & 0.008 & 0.001 & 1.30E-09 & 23 & 14385 & 0.61 & -0.021 & 0.026 & $4.22 \mathrm{E}-01$ & 0 & 3.52E-05 \\
\hline rs10823968 & $10: 74738269$ & $\mathrm{~A} / \mathrm{T}$ & 0.63 & 0.008 & 0.001 & 2.10E-08 & 23 & 14387 & 0.65 & 0.009 & 0.027 & 7.29E-01 & 3.1 & 3.08E-05 \\
\hline rs $17553262^{c}$ & 10:92912773 & $\mathrm{C} / \mathrm{A}$ & 0.12 & 0.013 & 0.002 & 5.30E-09 & 9 & 4488 & \multicolumn{6}{|c|}{ Excluded for MR } \\
\hline rs7077678 & $10: 104438565$ & $\mathrm{C} / \mathrm{T}$ & 0.62 & 0.009 & 0.001 & 2.60E-09 & 23 & 14387 & 0.62 & 0.000 & 0.026 & 9.93E-01 & 0 & 3.43E-05 \\
\hline rs12244388 & $10: 104640052$ & $\mathrm{~A} / \mathrm{G}$ & 0.34 & 0.013 & 0.001 & $1.40 \mathrm{E}-19$ & 23 & 14387 & 0.37 & $\underline{-0.055}$ & 0.026 & 3.57E-02 & 0 & 7.87E-05 \\
\hline rs3896224a & $10: 106467853$ & $\mathrm{~A} / \mathrm{G}$ & 0.59 & 0.010 & 0.001 & $1.10 \mathrm{E}-11$ & 23 & 14387 & 0.54 & $\overline{-0.008}$ & 0.026 & 7.52E-01 & 0 & 4.50E-05 \\
\hline rs34866095 & 11:16377356 & $G / A$ & 0.31 & 0.009 & 0.002 & $1.20 \mathrm{E}-08$ & 23 & 14387 & 0.33 & -0.044 & 0.028 & $1.11 \mathrm{E}-01$ & 12.6 & $3.16 \mathrm{E}-05$ \\
\hline rs75742406 & $11: 17070365$ & $G / A$ & 0.74 & 0.010 & 0.002 & 1.30E-09 & 23 & 14387 & 0.77 & -0.024 & 0.039 & $5.50 \mathrm{E}-01$ & 29.7 & 3.57E-05 \\
\hline rs17309874 & $11: 27667236$ & $A / G$ & 0.26 & 0.011 & 0.002 & $9.70 \mathrm{E}-13$ & 23 & 14387 & 0.22 & -0.037 & 0.031 & 2.33E-01 & 0 & $4.90 \mathrm{E}-05$ \\
\hline rs4391802 & $11: 28674592$ & $\mathrm{~A} / \mathrm{G}$ & 0.71 & 0.010 & 0.002 & $1.40 \mathrm{E}-11$ & 23 & 14387 & 0.71 & $\underline{0.05} \underline{7}$ & 0.029 & 4.64E-02 & 0 & 4.41E-05 \\
\hline rs112282219 & $11: 46632809$ & $A / G$ & 0.04 & 0.023 & 0.004 & $3.80 \mathrm{E}-11$ & 22 & 14205 & 0.04 & $0.02 \overline{3}$ & 0.069 & 7.38E-01 & 0 & 4.23E-05 \\
\hline rs9919670 & 11:112877304 & $\mathrm{A} / \mathrm{G}$ & 0.39 & 0.015 & 0.001 & $7.60 \mathrm{E}-27$ & 23 & 14387 & 0.39 & -0.013 & 0.026 & $6.26 \mathrm{E}-01$ & 0 & 1.10E-04 \\
\hline rs74086911 & 12:50015942 & $G / A$ & 0.93 & 0.015 & 0.003 & $2.10 \mathrm{E}-08$ & 23 & 14387 & 0.93 & -0.045 & 0.050 & 3.73E-01 & 0 & 3.02E-05 \\
\hline rs7297175 & $12: 56473808$ & $\mathrm{C} / \mathrm{T}$ & 0.57 & 0.008 & 0.001 & $6.60 \mathrm{E}-09$ & 23 & 14387 & 0.58 & 0.011 & 0.027 & 6.96E-01 & 0 & 3.23E-05 \\
\hline rs10879871 & $12: 75380511$ & $\mathrm{G} / \mathrm{T}$ & 0.66 & 0.010 & 0.001 & $5.00 \mathrm{E}-11$ & 23 & 14387 & 0.60 & -0.012 & 0.027 & $6.69 \mathrm{E}-01$ & 0 & 4.14E-05 \\
\hline rs12831617 & $12: 84758368$ & $\mathrm{~T} / \mathrm{C}$ & 0.24 & 0.009 & 0.002 & $1.90 \mathrm{E}-08$ & 23 & 14387 & 0.25 & 0.023 & 0.029 & 4.42E-01 & 0 & 3.04E-05 \\
\hline rs6562474 & $13: 67332812$ & $\mathrm{C} / \mathrm{G}$ & 0.65 & 0.008 & 0.001 & $1.00 \mathrm{E}-08$ & 23 & 14387 & 0.65 & -0.004 & 0.027 & 8.86E-01 & 0 & 3.18E-05 \\
\hline rs7333559 & $13: 100546450$ & $G / A$ & 0.21 & 0.011 & 0.002 & $3.20 \mathrm{E}-10$ & 21 & 13839 & 0.24 & -0.034 & 0.033 & 2.96E-01 & 7.9 & $3.85 \mathrm{E}-05$ \\
\hline rs860326 & $14: 57342912$ & $\mathrm{C} / \mathrm{T}$ & 0.43 & 0.008 & 0.001 & 2.70E-09 & 23 & 14387 & 0.42 & 0.011 & 0.026 & 6.83E-01 & 18 & 3.40E-05 \\
\hline rs7155595 & $14: 77502546$ & $\mathrm{C} / \mathrm{A}$ & 0.33 & 0.009 & 0.001 & 2.50E-09 & 23 & 14387 & 0.32 & -0.012 & 0.028 & $6.75 \mathrm{E}-01$ & 0 & 3.44E-05 \\
\hline rs3742365 & $14: 104198251$ & $\mathrm{C} / \mathrm{T}$ & 0.40 & 0.011 & 0.001 & $2.50 \mathrm{E}-14$ & 23 & 14387 & 0.37 & 0.001 & 0.027 & $9.77 \mathrm{E}-01$ & 0 & $5.61 \mathrm{E}-05$ \\
\hline rs35175834 & 15:47680815 & $A / G$ & 0.21 & 0.016 & 0.002 & $4.60 \mathrm{E}-22$ & 23 & 14387 & 0.22 & -0.043 & 0.031 & 1.62E-01 & 10.2 & 8.98E-05 \\
\hline rs28485305 & $15: 74044197$ & $\mathrm{C} / \mathrm{T}$ & 0.63 & 0.008 & 0.001 & $2.60 \mathrm{E}-08$ & 23 & 14387 & 0.60 & 0.015 & 0.026 & $5.61 \mathrm{E}-01$ & 0 & 2.98E-05 \\
\hline rs8042849 & $15: 78817929$ & $\mathrm{C} / \mathrm{T}$ & 0.34 & 0.019 & 0.001 & $1.80 \mathrm{E}-39$ & 23 & 14387 & 0.39 & -0.019 & 0.027 & 4.81E-01 & 0 & 1.66E-04 \\
\hline rs8042134 & $15: 97514404$ & $\mathrm{G} / \mathrm{T}$ & 0.46 & 0.010 & 0.001 & $1.30 \mathrm{E}-12$ & 23 & 14387 & 0.44 & 0.047 & 0.026 & 7.40E-02 & 0 & 4.91E-05 \\
\hline rs6598539 & $15: 99204483$ & $\mathrm{C} / \mathrm{T}$ & 0.51 & 0.008 & 0.001 & 4.50E-09 & 23 & 14387 & 0.49 & -0.019 & 0.026 & 4.64E-01 & 23.9 & 3.32E-05 \\
\hline rs11861214 & $16: 746611$ & $\mathrm{G} / \mathrm{T}$ & 0.78 & 0.009 & 0.002 & $2.00 \mathrm{E}-08$ & 22 & 14161 & 0.79 & 0.046 & 0.032 & $1.49 \mathrm{E}-01$ & 17.8 & 3.03E-05 \\
\hline
\end{tabular}




\begin{tabular}{|c|c|c|c|c|c|c|c|c|c|c|c|c|c|c|}
\hline \multirow[b]{2}{*}{ SNP } & \multirow[b]{2}{*}{ Chr:Pos (GRCh37) } & \multirow[b]{2}{*}{ EA/BA } & \multicolumn{4}{|c|}{ Exposure } & \multicolumn{7}{|c|}{ Courage-PD } & \multirow[b]{2}{*}{$\mathbf{R}^{2}$} \\
\hline & & & EAF & Beta & SE & P-value & N studies & N samples & EAF & Beta & SE & P-value & $\left.\right|^{2}(\%)$ & \\
\hline rs12708665 & $16: 24728227$ & $G / A$ & 0.72 & 0.009 & 0.002 & 3.50E-09 & 23 & 14387 & 0.68 & -0.013 & 0.028 & 6.36E-01 & 0 & 3.36E-05 \\
\hline rs57611503 & $16: 31165795$ & $\mathrm{G} / \mathrm{A}$ & 0.48 & 0.008 & 0.001 & 4.00E-08 & 20 & 13192 & 0.46 & $\underline{-0.100}$ & 0.029 & 4.95E-04 & 12.5 & 3.00E-05 \\
\hline rs889398 & 16:69556715 & $\mathrm{C} / \mathrm{T}$ & 0.59 & 0.009 & 0.001 & $6.30 \mathrm{E}-11$ & 18 & 10342 & 0.59 & 0.013 & 0.048 & 7.86E-01 & 45.4 & 4.14E-05 \\
\hline rs60952428 & $16: 75640521$ & $\mathrm{~T} / \mathrm{C}$ & 0.91 & 0.013 & 0.002 & 3.00E-08 & 14 & 6978 & \multicolumn{6}{|c|}{ Excluded for MR } \\
\hline rs1050847 & $16: 87443734$ & $\mathrm{C} / \mathrm{T}$ & 0.43 & 0.008 & 0.001 & $1.40 \mathrm{E}-08$ & 23 & 14387 & 0.49 & -0.013 & 0.026 & $6.21 \mathrm{E}-01$ & 11.3 & 3.11E-05 \\
\hline rs369230 & $16: 89645437$ & $T / G$ & 0.69 & 0.009 & 0.002 & $1.80 \mathrm{E}-09$ & 22 & 14161 & 0.74 & -0.043 & 0.030 & $1.55 \mathrm{E}-01$ & 3 & 3.52E-05 \\
\hline rs8614 & $17: 27588806$ & $A / C$ & 0.18 & 0.011 & 0.002 & $1.80 \mathrm{E}-10$ & 22 & 13821 & 0.17 & $\underline{0.08} \underline{4}$ & 0.037 & 2.24E-02 & 0 & 3.92E-05 \\
\hline rs732083 & 17:37834367 & $\mathrm{G} / \mathrm{A}$ & 0.33 & 0.008 & 0.001 & $1.50 \mathrm{E}-08$ & 23 & 14387 & 0.36 & -0.028 & 0.028 & 3.23E-01 & 15.4 & $3.10 \mathrm{E}-05$ \\
\hline rs9904288 & $17: 47031973$ & $\mathrm{~T} / \mathrm{C}$ & 0.71 & 0.008 & 0.002 & $3.10 \mathrm{E}-08$ & 23 & 14387 & 0.71 & -0.018 & 0.028 & 5.38E-01 & 0 & 2.94E-05 \\
\hline rs67596067 & $17: 50333733$ & $A / G$ & 0.35 & 0.009 & 0.001 & $1.20 \mathrm{E}-09$ & 23 & 14387 & 0.33 & 0.009 & 0.027 & 7.47E-01 & 0 & $3.59 \mathrm{E}-05$ \\
\hline rs12967855 & $18: 35138245$ & $A / G$ & 0.33 & 0.008 & 0.001 & $3.10 \mathrm{E}-08$ & 23 & 14387 & 0.35 & -0.040 & 0.028 & $1.52 \mathrm{E}-01$ & 1.3 & 2.97E-05 \\
\hline rs62098013 & $18: 50863861$ & $A / G$ & 0.36 & 0.009 & 0.001 & 4.10E-09 & 23 & 14387 & 0.36 & 0.043 & 0.027 & $1.14 \mathrm{E}-01$ & 23.6 & 3.38E-05 \\
\hline rs71367545 & 18:77576337 & $A / G$ & 0.21 & 0.010 & 0.002 & 1.40E-09 & 23 & 14387 & 0.17 & 0.023 & 0.034 & 4.98E-01 & 0 & 3.53E-05 \\
\hline rs76608582 & 19:4474725 & $\mathrm{C} / \mathrm{A}$ & 0.95 & 0.022 & 0.003 & $3.20 \mathrm{E}-10$ & \multicolumn{8}{|c|}{ NA in COURAGE-PD } \\
\hline rs35343344 & 19:18471610 & $\mathrm{C} / \mathrm{A}$ & 0.73 & 0.009 & 0.002 & 8.80E-09 & 23 & 14387 & 0.75 & 0.056 & 0.031 & 7.27E-02 & 0 & 3.30E-05 \\
\hline rs4814873 & 20:19616429 & $\mathrm{C} / \mathrm{T}$ & 0.77 & 0.010 & 0.002 & 2.90E-09 & 23 & 14387 & 0.75 & -0.013 & 0.030 & $6.68 \mathrm{E}-01$ & 0 & 3.38E-05 \\
\hline rs6119897 & 20:31145415 & $A / G$ & 0.24 & 0.013 & 0.002 & $3.60 \mathrm{E}-15$ & 23 & 14387 & 0.21 & -0.018 & 0.032 & 5.89E-01 & 0 & 5.95E-05 \\
\hline rs12481282 & $20: 44761377$ & $\mathrm{C} / \mathrm{G}$ & 0.28 & 0.009 & 0.002 & 7.80E-09 & 23 & 14387 & 0.26 & -0.020 & 0.030 & $5.15 \mathrm{E}-01$ & 0 & $3.21 \mathrm{E}-05$ \\
\hline rs348809 & $20: 59032097$ & $G / A$ & 0.65 & 0.008 & 0.001 & $1.30 \mathrm{E}-08$ & 23 & 14387 & 0.62 & -0.012 & 0.027 & $6.62 \mathrm{E}-01$ & 0 & $3.11 \mathrm{E}-05$ \\
\hline rs6011779 & $20: 61984317$ & $\mathrm{C} / \mathrm{T}$ & 0.19 & 0.019 & 0.002 & $2.30 \mathrm{E}-27$ & 22 & 14161 & 0.22 & -0.017 & 0.032 & $6.00 \mathrm{E}-01$ & 0 & 1.13E-04 \\
\hline rs147412694 & 21:40702786 & $A / G$ & 0.15 & 0.012 & 0.002 & 2.90E-09 & 23 & 14387 & 0.14 & -0.024 & 0.038 & $5.22 \mathrm{E}-01$ & 0 & $3.41 \mathrm{E}-05$ \\
\hline rs2838834 & $21: 46665208$ & $\mathrm{~T} / \mathrm{C}$ & 0.30 & 0.009 & 0.002 & $6.30 \mathrm{E}-10$ & 23 & 14387 & 0.29 & 0.016 & 0.028 & 5.61E-01 & 19.7 & 3.69E-05 \\
\hline rs136233 & $22: 31212410$ & $\mathrm{G} / \mathrm{A}$ & 0.19 & 0.010 & 0.002 & $1.80 \mathrm{E}-08$ & 23 & 14387 & 0.19 & -0.037 & 0.032 & $2.50 \mathrm{E}-01$ & 0 & 3.06E-05 \\
\hline rs202645 & 22:41798520 & $\mathrm{G} / \mathrm{A}$ & 0.80 & 0.010 & 0.002 & 3.90E-09 & 23 & 14387 & 0.77 & $\underline{0.12} 2$ & 0.032 & 1.47E-04 & 3.5 & 3.34E-05 \\
\hline \multicolumn{15}{|c|}{ Smoking initiation (per 1-SD increase in the prevalence of ever smoking) } \\
\hline rs12130857 & $1: 7791461$ & $\mathrm{G} / \mathrm{A}$ & 0.68 & 0.018 & 0.003 & $3.65 \mathrm{E}-11$ & 23 & 14387 & 0.69 & -0.027 & 0.028 & 3.34E-01 & 0 & $1.42 \mathrm{E}-04$ \\
\hline rs3820277 & $1: 18436657$ & $\mathrm{G} / \mathrm{T}$ & 0.47 & 0.019 & 0.003 & $1.57 \mathrm{E}-13$ & 23 & 14387 & 0.50 & -0.032 & 0.037 & 3.90E-01 & 42.3 & $1.77 \mathrm{E}-04$ \\
\hline rs1889571 & 1:32195819 & $\mathrm{G} / \mathrm{T}$ & 0.13 & 0.022 & 0.004 & 4.19E-09 & 23 & 14387 & 0.12 & 0.010 & 0.040 & 8.13E-01 & 0 & $1.12 \mathrm{E}-04$ \\
\hline rs10914684 & 1:33795572 & $\mathrm{G} / \mathrm{A}$ & 0.68 & 0.016 & 0.003 & 6.32E-09 & 23 & 14387 & 0.66 & -0.027 & 0.027 & $3.16 \mathrm{E}-01$ & 9.1 & 1.09E-04 \\
\hline rs951740 & 1:44011737 & $A / G$ & 0.62 & 0.030 & 0.003 & $3.82 E-29$ & 23 & 14387 & 0.61 & -0.041 & 0.026 & $1.24 \mathrm{E}-01$ & 5.5 & 4.09E-04 \\
\hline rs12022778 & $1: 50603995$ & $\mathrm{C} / \mathrm{A}$ & 0.20 & 0.027 & 0.003 & $3.18 \mathrm{E}-17$ & 23 & 14387 & 0.18 & 0.060 & 0.033 & 6.97E-02 & 5 & $2.32 \mathrm{E}-04$ \\
\hline rs4912332 & $1: 58815243$ & $\mathrm{~T} / \mathrm{C}$ & 0.49 & 0.014 & 0.003 & $2.94 \mathrm{E}-08$ & 23 & 14387 & 0.47 & 0.028 & 0.026 & 2.82E-01 & 0 & 9.97E-05 \\
\hline rs80054503 & $1: 72900406$ & $\mathrm{~T} / \mathrm{C}$ & 0.88 & 0.024 & 0.004 & 3.10E-09 & \multicolumn{8}{|c|}{ NA in COURAGE-PD } \\
\hline rs10789369 & $1: 73824909$ & $A / G$ & 0.38 & 0.023 & 0.003 & 3.39E-19 & 23 & 14387 & 0.43 & -0.041 & 0.026 & $1.21 \mathrm{E}-01$ & 12.5 & $2.60 \mathrm{E}-04$ \\
\hline rs1514176 & $1: 74991596$ & $G / A$ & 0.42 & 0.019 & 0.003 & $7.67 \mathrm{E}-14$ & 23 & 14387 & 0.42 & 0.007 & 0.026 & 8.02E-01 & 16.3 & $1.81 \mathrm{E}-04$ \\
\hline rs11162019 & $1: 87913176$ & $\mathrm{C} / \mathrm{T}$ & 0.64 & 0.015 & 0.003 & 5.06E-09 & 23 & 14387 & 0.65 & -0.026 & 0.027 & 3.35E-01 & 10.5 & 1.11E-04 \\
\hline rs1008078 & 1:91189731 & $\mathrm{T} / \mathrm{C}$ & 0.40 & 0.023 & 0.003 & $1.63 E-18$ & 23 & 14387 & 0.40 & -0.025 & 0.040 & 5.27E-01 & 48.6 & $2.50 \mathrm{E}-04$ \\
\hline rs12027999 & $1: 154206358$ & $\mathrm{~T} / \mathrm{C}$ & 0.88 & 0.024 & 0.004 & 5.33E-10 & 23 & 14387 & 0.89 & 0.001 & 0.042 & $9.77 \mathrm{E}-01$ & 0 & $1.25 \mathrm{E}-04$ \\
\hline rs45444697 & $1: 155034632$ & $\mathrm{G} / \mathrm{C}$ & 0.21 & 0.020 & 0.003 & $2.72 \mathrm{E}-10$ & 23 & 14387 & 0.20 & -0.019 & 0.033 & 5.69E-01 & 21.8 & 1.30E-04 \\
\hline rs2901785 & $1: 174104743$ & $\mathrm{G} / \mathrm{A}$ & 0.55 & 0.017 & 0.003 & $1.47 \mathrm{E}-11$ & 23 & 14387 & 0.54 & -0.008 & 0.026 & $7.60 \mathrm{E}-01$ & 10.4 & $1.48 \mathrm{E}-04$ \\
\hline rs147052174 & $1: 179783167$ & $\mathrm{~T} / \mathrm{G}$ & 0.02 & 0.062 & 0.010 & $2.30 \mathrm{E}-10$ & 13 & 7882 & \multicolumn{6}{|c|}{ Excluded for MR } \\
\hline rs35656245 & 1:190957480 & $A / G$ & 0.28 & 0.016 & 0.003 & $2.23 E-08$ & 23 & 14387 & 0.29 & -0.003 & 0.028 & $9.14 \mathrm{E}-01$ & 0 & 1.02E-04 \\
\hline rs12739243 & $1: 210302043$ & $\mathrm{~T} / \mathrm{C}$ & 0.78 & 0.021 & 0.003 & $4.45 E-12$ & 23 & 14387 & 0.78 & 0.017 & 0.031 & $5.70 \mathrm{E}-01$ & 0 & 1.56E-04 \\
\hline rs876793 & $1: 237852083$ & $\mathrm{~T} / \mathrm{C}$ & 0.65 & 0.018 & 0.003 & $5.69 \mathrm{E}-11$ & 23 & 14387 & 0.66 & 0.051 & 0.028 & 6.89E-02 & 17 & 1.46E-04 \\
\hline rs6731872 & $2: 624205$ & $\mathrm{G} / \mathrm{T}$ & 0.83 & 0.032 & 0.003 & 5.35E-21 & 23 & 14387 & 0.80 & 0.016 & 0.033 & 6.34E-01 & 0 & 2.87E-04 \\
\hline rs1022376 & 2:22067213 & $\mathrm{T} / \mathrm{C}$ & 0.48 & 0.015 & 0.003 & $1.66 \mathrm{E}-08$ & 23 & 14387 & 0.51 & 0.002 & 0.026 & 9.33E-01 & 0 & 1.09E-04 \\
\hline rs61533748 & $2: 22582968$ & $\mathrm{C} / \mathrm{T}$ & 0.38 & 0.017 & 0.003 & $2.82 \mathrm{E}-11$ & 23 & 14387 & 0.37 & -0.012 & 0.027 & $6.58 \mathrm{E}-01$ & 8 & $1.44 \mathrm{E}-04$ \\
\hline
\end{tabular}




\begin{tabular}{|c|c|c|c|c|c|c|c|c|c|c|c|c|c|c|}
\hline \multirow[b]{2}{*}{ SNP } & \multirow[b]{2}{*}{ Chr:Pos (GRCh37) } & \multirow[b]{2}{*}{ EA/BA } & \multicolumn{4}{|c|}{ Exposure } & \multicolumn{7}{|c|}{ Courage-PD } & \multirow[b]{2}{*}{$\mathbf{R}^{2}$} \\
\hline & & & EAF & Beta & SE & P-value & N studies & N samples & EAF & Beta & SE & P-value & $\left.\right|^{2}(\%)$ & \\
\hline rs2710634 & $2: 32808804$ & $\mathrm{~T} / \mathrm{C}$ & 0.48 & 0.018 & 0.003 & $3.36 \mathrm{E}-12$ & 23 & 14387 & 0.51 & -0.039 & 0.026 & $1.31 \mathrm{E}-01$ & 0 & 1.57E-04 \\
\hline rs7598402 & $2: 50735943$ & $\mathrm{C} / \mathrm{G}$ & 0.51 & 0.015 & 0.003 & 7.38E-09 & 23 & 14387 & 0.50 & \multicolumn{5}{|c|}{ Excluded for MR } \\
\hline rs10490159 & $2: 51341259$ & $\mathrm{~T} / \mathrm{C}$ & 0.39 & 0.017 & 0.003 & $3.86 \mathrm{E}-11$ & 23 & 14387 & 0.39 & -0.027 & 0.026 & 3.04E-01 & 0 & $1.42 \mathrm{E}-04$ \\
\hline rs359247 & $2: 60477052$ & T/A & 0.64 & 0.022 & 0.003 & $9.89 \mathrm{E}-17$ & 23 & 14387 & 0.61 & -0.017 & 0.027 & 5.36E-01 & 24.7 & $2.24 \mathrm{E}-04$ \\
\hline rs12714017 & $2: 80999398$ & $\mathrm{C} / \mathrm{T}$ & 0.51 & 0.015 & 0.003 & $3.65 \mathrm{E}-09$ & 23 & 14387 & 0.52 & 0.011 & 0.026 & $6.71 \mathrm{E}-01$ & 0 & $1.18 \mathrm{E}-04$ \\
\hline rs13392222 & $2: 100672408$ & $\mathrm{~A} / \mathrm{C}$ & 0.86 & 0.023 & 0.004 & $1.93 \mathrm{E}-10$ & 23 & 14387 & 0.87 & 0.012 & 0.039 & $7.53 \mathrm{E}-01$ & 0 & $1.31 \mathrm{E}-04$ \\
\hline rs1901477 & $2: 104126983$ & $\mathrm{G} / \mathrm{A}$ & 0.51 & 0.030 & 0.003 & 2.07E-31 & 23 & 14387 & 0.52 & 0.024 & 0.038 & 5.33E-01 & 45.5 & 4.63E-04 \\
\hline rs3811038 & $2: 113240183$ & $\mathrm{C} / \mathrm{T}$ & 0.28 & 0.019 & 0.003 & $1.58 \mathrm{E}-11$ & 23 & 14387 & 0.28 & -0.004 & 0.029 & $8.90 \mathrm{E}-01$ & 9.1 & 1.47E-04 \\
\hline rs34399632 & $2: 137571174$ & $\mathrm{G} / \mathrm{A}$ & 0.23 & 0.019 & 0.003 & $1.46 \mathrm{E}-10$ & 23 & 14387 & 0.17 & -0.035 & 0.044 & 4.30E-01 & 26.8 & 1.33E-04 \\
\hline rs6756212 & $2: 146140132$ & $\mathrm{C} / \mathrm{T}$ & 0.47 & 0.034 & 0.003 & $3.49 E-40$ & 23 & 14387 & 0.46 & -0.023 & 0.026 & $3.72 E-01$ & 3.4 & 5.71E-04 \\
\hline rs16826827 & $2: 147825689$ & $\mathrm{~T} / \mathrm{C}$ & 0.88 & 0.022 & 0.004 & $9.17 \mathrm{E}-09$ & 23 & 14387 & 0.89 & -0.041 & 0.040 & $3.08 \mathrm{E}-01$ & 0 & 1.07E-04 \\
\hline rs1445649 & $2: 155682556$ & $\mathrm{C} / \mathrm{T}$ & 0.54 & 0.021 & 0.003 & $8.48 \mathrm{E}-16$ & 23 & 14387 & 0.54 & -0.023 & 0.026 & $3.58 \mathrm{E}-01$ & 0 & $2.10 \mathrm{E}-04$ \\
\hline rs12474587 & $2: 162802993$ & $T / G$ & 0.43 & 0.024 & 0.003 & $4.83 E-21$ & 23 & 14387 & 0.40 & 0.043 & 0.027 & $1.08 \mathrm{E}-01$ & 5 & $2.88 \mathrm{E}-04$ \\
\hline rs13007361 & $2: 166250244$ & $A / G$ & 0.21 & 0.018 & 0.003 & 2.29E-08 & 23 & 14387 & 0.21 & 0.014 & 0.031 & 6.52E-01 & 9.7 & $1.01 \mathrm{E}-04$ \\
\hline rs6750529 & $2: 182027603$ & $\mathrm{~T} / \mathrm{C}$ & 0.74 & 0.020 & 0.003 & $9.26 \mathrm{E}-12$ & 23 & 14387 & 0.75 & -0.025 & 0.030 & $3.96 \mathrm{E}-01$ & 10.5 & $1.51 \mathrm{E}-04$ \\
\hline rs17229285 & 2:199523122 & $\mathrm{C} / \mathrm{T}$ & 0.50 & 0.015 & 0.003 & $1.27 \mathrm{E}-09$ & 23 & 14387 & 0.52 & 0.013 & 0.026 & $6.11 \mathrm{E}-01$ & 0 & $1.20 \mathrm{E}-04$ \\
\hline rs62193862 & $2: 202843875$ & $A / G$ & 0.10 & 0.024 & 0.004 & $1.99 \mathrm{E}-08$ & 12 & 6492 & \multicolumn{6}{|c|}{ Excluded for MR } \\
\hline rs4674993 & $2: 226332033$ & $A / G$ & 0.80 & 0.024 & 0.003 & $4.85 \mathrm{E}-14$ & 23 & 14387 & 0.80 & -0.006 & 0.044 & 8.84E-01 & 33.7 & $1.84 \mathrm{E}-04$ \\
\hline rs11713899 & $3: 2365026$ & $\mathrm{C} / \mathrm{A}$ & 0.17 & 0.019 & 0.003 & $3.15 \mathrm{E}-08$ & 23 & 14387 & 0.17 & -0.032 & 0.034 & $3.49 E-01$ & 0 & 9.93E-05 \\
\hline rs748832 & 3:16851202 & $\mathrm{G} / \mathrm{A}$ & 0.37 & 0.017 & 0.003 & $6.60 \mathrm{E}-11$ & 23 & 14387 & 0.34 & 0.051 & 0.027 & 5.61E-02 & 0 & $1.38 \mathrm{E}-04$ \\
\hline rs2526390 & $3: 50192760$ & $\mathrm{~T} / \mathrm{C}$ & 0.33 & 0.020 & 0.003 & $3.62 \mathrm{E}-14$ & 23 & 14387 & 0.33 & -0.007 & 0.027 & 7.88E-01 & 0 & $1.86 \mathrm{E}-04$ \\
\hline rs221988 & 3:64234307 & $A / C$ & 0.62 & 0.015 & 0.003 & $1.43 \mathrm{E}-08$ & 23 & 14387 & 0.62 & 0.024 & 0.027 & $3.90 \mathrm{E}-01$ & 0 & 1.05E-04 \\
\hline rs11128203 & 3:71064431 & $\mathrm{A} / \mathrm{T}$ & 0.53 & 0.020 & 0.003 & $1.29 \mathrm{E}-15$ & 10 & 4792 & \multicolumn{6}{|c|}{ Excluded for MR } \\
\hline rs62246017 & 3:71483084 & $\mathrm{G} / \mathrm{A}$ & 0.68 & 0.016 & 0.003 & 3.03E-09 & 23 & 14387 & 0.67 & -0.045 & 0.029 & $1.18 \mathrm{E}-01$ & 7.9 & $1.14 \mathrm{E}-04$ \\
\hline rs12633090 & 3:83241365 & $\mathrm{G} / \mathrm{C}$ & 0.82 & 0.023 & 0.003 & $3.16 \mathrm{E}-12$ & 23 & 14387 & 0.80 & 0.065 & 0.043 & $1.31 \mathrm{E}-01$ & 31.5 & $1.58 \mathrm{E}-04$ \\
\hline rs1549979 & $3: 85460131$ & $\mathrm{C} / \mathrm{T}$ & 0.38 & 0.025 & 0.003 & $8.80 \mathrm{E}-21$ & 23 & 14387 & 0.39 & 0.019 & 0.026 & 4.69E-01 & 0 & $2.85 \mathrm{E}-04$ \\
\hline rs6437769 & $3: 107997514$ & $\mathrm{~T} / \mathrm{C}$ & 0.58 & 0.014 & 0.003 & $3.74 \mathrm{E}-08$ & 23 & 14387 & 0.59 & 0.024 & 0.026 & $3.54 \mathrm{E}-01$ & 12.9 & 9.84E-05 \\
\hline rs9288999 & 3:114147927 & $A / G$ & 0.74 & 0.017 & 0.003 & $1.50 \mathrm{E}-09$ & 23 & 14387 & 0.73 & -0.043 & 0.029 & 1.47E-01 & 0 & $1.18 \mathrm{E}-04$ \\
\hline rs6438436 & $3: 117822149$ & $\mathrm{~T} / \mathrm{C}$ & 0.82 & 0.025 & 0.003 & $5.33 E-14$ & 23 & 14387 & 0.82 & 0.058 & 0.035 & $9.38 \mathrm{E}-02$ & 16.4 & 1.84E-04 \\
\hline rs9826984 & 3:131945722 & $\mathrm{G} / \mathrm{A}$ & 0.46 & 0.014 & 0.003 & 3.87E-08 & 23 & 14387 & 0.44 & 0.017 & 0.026 & $5.24 \mathrm{E}-01$ & 0.3 & $9.80 \mathrm{E}-05$ \\
\hline rs2279829 & $3: 147106319$ & $\mathrm{C} / \mathrm{T}$ & 0.78 & 0.017 & 0.003 & $2.05 \mathrm{E}-08$ & 23 & 14387 & 0.80 & 0.024 & 0.033 & 4.57E-01 & 0 & $1.02 \mathrm{E}-04$ \\
\hline rs2319545 & $3: 147719648$ & $\mathrm{~A} / \mathrm{C}$ & 0.15 & 0.023 & 0.004 & $8.30 \mathrm{E}-11$ & 23 & 14387 & 0.13 & 0.017 & 0.052 & $7.45 \mathrm{E}-01$ & 34.6 & 1.37E-04 \\
\hline rs 1714521 & $3: 158284861$ & $\mathrm{~A} / \mathrm{C}$ & 0.59 & 0.016 & 0.003 & $3.07 E-10$ & 23 & 14387 & 0.61 & -0.007 & 0.026 & 8.01E-01 & 22.4 & $1.29 \mathrm{E}-04$ \\
\hline rs1449012 & 3:159048333 & $\mathrm{C} / \mathrm{T}$ & 0.54 & 0.015 & 0.003 & $1.77 \mathrm{E}-09$ & 23 & 14387 & 0.53 & -0.010 & 0.036 & 7.82E-01 & 37.8 & $1.18 \mathrm{E}-04$ \\
\hline rs1187820 & 3:173072584 & $\mathrm{C} / \mathrm{T}$ & 0.56 & 0.014 & 0.003 & $2.69 \mathrm{E}-08$ & 23 & 14387 & 0.57 & 0.015 & 0.038 & $6.84 \mathrm{E}-01$ & 34.4 & $1.00 \mathrm{E}-04$ \\
\hline rs7631379 & $3: 181409057$ & $\mathrm{C} / \mathrm{T}$ & 0.21 & 0.021 & 0.003 & $3.94 \mathrm{E}-11$ & 23 & 14387 & 0.19 & -0.059 & 0.047 & $2.12 \mathrm{E}-01$ & 36.2 & $1.42 \mathrm{E}-04$ \\
\hline rs4140932 & $4: 15458598$ & $\mathrm{~T} / \mathrm{A}$ & 0.57 & 0.014 & 0.003 & $4.89 \mathrm{E}-08$ & 23 & 14387 & 0.57 & \multicolumn{5}{|c|}{ Excluded for MR } \\
\hline rs59537158 & 4:28246049 & $\mathrm{T} / \mathrm{C}$ & 0.21 & 0.022 & 0.003 & $4.62 E-13$ & 23 & 14387 & 0.20 & -0.001 & 0.033 & $9.73 \mathrm{E}-01$ & 12.1 & 1.70E-04 \\
\hline rs58400863 & $4: 31184484$ & $\mathrm{G} / \mathrm{A}$ & 0.65 & 0.020 & 0.003 & $4.89 \mathrm{E}-14$ & 23 & 14387 & 0.63 & 0.018 & 0.027 & 5.09E-01 & 3.3 & 1.84E-04 \\
\hline rs112725451 & $4: 68017710$ & $\mathrm{~T} / \mathrm{C}$ & 0.17 & 0.026 & 0.003 & $1.65 \mathrm{E}-14$ & 23 & 14387 & 0.18 & 0.010 & 0.033 & $7.69 \mathrm{E}-01$ & 0 & $1.91 \mathrm{E}-04$ \\
\hline rs1160685 & $4: 94052854$ & $\mathrm{G} / \mathrm{C}$ & 0.45 & 0.015 & 0.003 & 2.31E-09 & 23 & 14387 & 0.49 & \multicolumn{5}{|c|}{ Excluded for MR } \\
\hline rs3934797 & $4: 112467612$ & $\mathrm{G} / \mathrm{A}$ & 0.82 & 0.021 & 0.003 & $1.12 \mathrm{E}-10$ & 23 & 14387 & 0.83 & 0.015 & 0.035 & $6.77 \mathrm{E}-01$ & 18.4 & 1.35E-04 \\
\hline rs71602617 & $4: 136406155$ & $\mathrm{C} / \mathrm{T}$ & 0.78 & 0.018 & 0.003 & $2.10 \mathrm{E}-08$ & 23 & 14387 & 0.80 & -0.010 & 0.032 & $7.58 \mathrm{E}-01$ & 0 & 1.07E-04 \\
\hline rs7696257 & $4: 137474783$ & $A / G$ & 0.37 & 0.015 & 0.003 & $6.78 \mathrm{E}-09$ & 23 & 14387 & 0.35 & -0.006 & 0.027 & 8.13E-01 & 7 & $1.09 \mathrm{E}-04$ \\
\hline rs1116690 & $4: 143510148$ & $\mathrm{G} / \mathrm{A}$ & 0.74 & 0.016 & 0.003 & $2.16 \mathrm{E}-08$ & 21 & 13928 & 0.71 & -0.020 & 0.030 & $5.05 \mathrm{E}-01$ & 0 & $1.02 \mathrm{E}-04$ \\
\hline rs13110073 & $4: 147797913$ & $\mathrm{~T} / \mathrm{C}$ & 0.60 & 0.025 & 0.003 & $3.24 \mathrm{E}-21$ & 23 & 14387 & 0.62 & -0.055 & 0.026 & 3.61E-02 & 0 & 2.90E-04 \\
\hline rs62340589 & $4: 176875795$ & $\mathrm{C} / \mathrm{G}$ & 0.20 & 0.017 & 0.003 & $4.31 \mathrm{E}-08$ & 23 & 14387 & 0.19 & -0.002 & 0.033 & $9.48 \mathrm{E}-01$ & 0 & $9.74 \mathrm{E}-05$ \\
\hline rs12517438 & $5: 30842054$ & $\mathrm{G} / \mathrm{T}$ & 0.54 & 0.015 & 0.003 & $1.89 \mathrm{E}-09$ & 23 & 14387 & 0.52 & 0.005 & 0.026 & $8.46 \mathrm{E}-01$ & 0 & 1.17E-04 \\
\hline
\end{tabular}




\begin{tabular}{|c|c|c|c|c|c|c|c|c|c|c|c|c|c|c|}
\hline \multirow[b]{2}{*}{ SNP } & \multirow[b]{2}{*}{ Chr:Pos (GRCh37) } & \multirow[b]{2}{*}{ EA/BA } & \multicolumn{4}{|c|}{ Exposure } & \multicolumn{7}{|c|}{ Courage-PD } & \multirow[b]{2}{*}{$\mathbf{R}^{2}$} \\
\hline & & & EAF & Beta & SE & P-value & N studies & N samples & EAF & Beta & SE & P-value & $\mathbf{I}^{2}(\%)$ & \\
\hline rs35375873 & $5: 43190647$ & $\mathrm{G} / \mathrm{C}$ & 0.89 & 0.027 & 0.004 & $3.29 \mathrm{E}-11$ & 15 & 8384 & & \multicolumn{5}{|c|}{ Excluded for MR } \\
\hline rs71592686 & $5: 60121271$ & $\mathrm{C} / \mathrm{T}$ & 0.27 & 0.021 & 0.003 & $3.85 \mathrm{E}-13$ & 23 & 14387 & 0.26 & 0.055 & 0.029 & $5.69 \mathrm{E}-02$ & 19.2 & 1.71E-04 \\
\hline rs6874731 & $5: 80263865$ & $\mathrm{G} / \mathrm{T}$ & 0.48 & 0.015 & 0.003 & 1.83E-09 & 23 & 14387 & 0.47 & -0.002 & 0.026 & $9.45 \mathrm{E}-01$ & 0 & 1.17E-04 \\
\hline rs6452785 & $5: 87685500$ & $\mathrm{C} / \mathrm{T}$ & 0.53 & 0.027 & 0.003 & $4.69 \mathrm{E}-26$ & 23 & 14387 & 0.51 & -0.044 & 0.026 & 8.56E-02 & 0 & $3.60 \mathrm{E}-04$ \\
\hline rs42417 & 5:94198290 & $\mathrm{T} / \mathrm{C}$ & 0.69 & 0.017 & 0.003 & 8.27E-10 & 23 & 14387 & 0.70 & $\underline{-0.079}$ & 0.037 & 3.33E-02 & 29 & $1.22 E-04$ \\
\hline rs72780746 & $5: 103929588$ & $\mathrm{~T} / \mathrm{C}$ & 0.83 & 0.026 & 0.003 & $2.05 \mathrm{E}-14$ & 23 & 14387 & 0.81 & -0.071 & 0.033 & 2.97E-02 & 6.7 & $1.90 \mathrm{E}-04$ \\
\hline rs329124 & $5: 133865452$ & $A / G$ & 0.57 & 0.016 & 0.003 & $1.96 \mathrm{E}-10$ & 23 & 14387 & 0.57 & $\overline{-0.042}$ & 0.026 & $1.01 \mathrm{E}-01$ & 0 & $1.31 \mathrm{E}-04$ \\
\hline rs1385108 & $5: 154839646$ & $\mathrm{~T} / \mathrm{C}$ & 0.24 & 0.019 & 0.003 & $3.84 \mathrm{E}-10$ & 23 & 14387 & 0.22 & -0.017 & 0.031 & 5.71E-01 & 0 & 1.27E-04 \\
\hline rs6890961 & $5: 166778503$ & $\mathrm{C} / \mathrm{T}$ & 0.38 & 0.019 & 0.003 & $2.13 \mathrm{E}-13$ & 23 & 14387 & 0.40 & -0.038 & 0.028 & 1.68E-01 & 0 & $1.75 \mathrm{E}-04$ \\
\hline rs4044321 & $5: 166989513$ & $A / G$ & 0.36 & 0.023 & 0.003 & $1.75 \mathrm{E}-17$ & 23 & 14387 & 0.37 & -0.016 & 0.028 & 5.63E-01 & 0 & 2.35E-04 \\
\hline rs2173019 & 5:167614971 & $\mathrm{A} / \mathrm{T}$ & 0.18 & 0.028 & 0.003 & $2.98 \mathrm{E}-17$ & 23 & 14387 & 0.17 & 0.051 & 0.034 & 1.37E-01 & 0 & 2.32E-04 \\
\hline rs1150668 & 6:28129789 & $T / G$ & 0.58 & 0.019 & 0.003 & $8.54 \mathrm{E}-13$ & 23 & 14387 & 0.59 & 0.020 & 0.027 & $4.68 \mathrm{E}-01$ & 0 & 1.67E-04 \\
\hline rs3218116 & $6: 41901763$ & $\mathrm{C} / \mathrm{T}$ & 0.74 & 0.020 & 0.003 & $1.05 \mathrm{E}-11$ & 23 & 14387 & 0.77 & -0.010 & 0.030 & 7.49E-01 & 0 & $1.50 \mathrm{E}-04$ \\
\hline rs160631 & $6: 52895230$ & $\mathrm{~T} / \mathrm{G}$ & 0.27 & 0.017 & 0.003 & 1.87E-09 & 23 & 14387 & 0.28 & 0.042 & 0.029 & $1.47 \mathrm{E}-01$ & 0 & 1.17E-04 \\
\hline rs7743165 & $6: 67521222$ & $\mathrm{G} / \mathrm{T}$ & 0.50 & 0.019 & 0.003 & $4.15 E-14$ & 23 & 14387 & 0.47 & -0.060 & 0.034 & 8.30E-02 & 32.5 & 1.85E-04 \\
\hline rs10945141 & $6: 69470709$ & $A / G$ & 0.26 & 0.018 & 0.003 & $3.59 \mathrm{E}-10$ & 23 & 14387 & 0.26 & 0.001 & 0.029 & $9.68 \mathrm{E}-01$ & 0 & $1.28 \mathrm{E}-04$ \\
\hline rs17554906 & $6: 92226609$ & $\mathrm{C} / \mathrm{G}$ & 0.44 & 0.014 & 0.003 & 3.14E-08 & 23 & 14387 & 0.42 & \multicolumn{5}{|c|}{ Excluded for MR } \\
\hline rs6568832 & $6: 97702876$ & $A / G$ & 0.75 & 0.019 & 0.003 & $1.74 \mathrm{E}-10$ & 23 & 14387 & 0.74 & 0.023 & 0.039 & 5.47E-01 & 28.9 & 1.32E-04 \\
\hline rs12195240 & 6:98636905 & $A / G$ & 0.28 & 0.025 & 0.003 & $1.08 \mathrm{E}-18$ & 23 & 14387 & 0.30 & -0.041 & 0.028 & $1.39 \mathrm{E}-01$ & 0 & 2.53E-04 \\
\hline rs6936160 & $6: 100347745$ & $\mathrm{~T} / \mathrm{C}$ & 0.70 & 0.020 & 0.003 & $4.20 \mathrm{E}-13$ & 23 & 14387 & 0.69 & 0.018 & 0.028 & 5.17E-01 & 0 & 1.70E-04 \\
\hline rs118202 & 6:111658371 & $\mathrm{G} / \mathrm{T}$ & 0.19 & 0.037 & 0.003 & $1.90 \mathrm{E}-29$ & 23 & 14387 & 0.19 & -0.060 & 0.043 & $1.63 \mathrm{E}-01$ & 29.2 & 4.12E-04 \\
\hline rs1737329 & $6: 163807748$ & $\mathrm{G} / \mathrm{C}$ & 0.74 & 0.017 & 0.003 & 5.08E-09 & 23 & 14387 & 0.73 & -0.014 & 0.041 & 7.41E-01 & 36.1 & $1.11 \mathrm{E}-04$ \\
\hline rs6948707 & 7:1870794 & $\mathrm{G} / \mathrm{T}$ & 0.42 & 0.024 & 0.003 & 4.24E-21 & 23 & 14387 & 0.41 & $<0.001$ & 0.026 & $9.93 \mathrm{E}-01$ & 11 & 2.89E-04 \\
\hline rs7809303 & 7:69484366 & $\mathrm{G} / \mathrm{A}$ & 0.68 & 0.021 & 0.003 & $3.48 \mathrm{E}-15$ & 23 & 14387 & 0.70 & -0.053 & 0.027 & $5.14 \mathrm{E}-02$ & 0 & 2.01E-04 \\
\hline rs $1030015^{a}$ & $7: 78139581$ & $\mathrm{~T} / \mathrm{G}$ & 0.52 & 0.014 & 0.003 & $2.15 \mathrm{E}-08$ & 23 & 14387 & 0.52 & 0.009 & 0.031 & 7.75E-01 & 23.1 & $1.02 \mathrm{E}-04$ \\
\hline rs4727189 & $7: 88442568$ & $\mathrm{C} / \mathrm{T}$ & 0.34 & 0.015 & 0.003 & 3.00E-08 & 23 & 14387 & 0.36 & 0.031 & 0.027 & $2.40 \mathrm{E}-01$ & 0 & 9.97E-05 \\
\hline rs11768481 & 7:96629103 & $\mathrm{C} / \mathrm{A}$ & 0.66 & 0.019 & 0.003 & $5.23 \mathrm{E}-12$ & 5 & 3107 & \multicolumn{6}{|c|}{ Excluded for MR } \\
\hline rs13437771 & 7:99071478 & $A / G$ & 0.84 & 0.027 & 0.004 & $1.39 \mathrm{E}-14$ & 23 & 14387 & 0.85 & -0.012 & 0.036 & 7.27E-01 & 0 & 1.93E-04 \\
\hline rs10233018 & 7:117523709 & $\mathrm{G} / \mathrm{A}$ & 0.52 & 0.025 & 0.003 & 4.77E-22 & 23 & 14387 & 0.50 & 0.014 & 0.026 & $5.76 \mathrm{E}-01$ & 0 & 3.03E-04 \\
\hline rs10953957 & 7:121954709 & $A / G$ & 0.39 & 0.014 & 0.003 & 3.66E-08 & 23 & 14387 & 0.39 & 0.036 & 0.027 & 1.77E-01 & 10.3 & $9.84 \mathrm{E}-05$ \\
\hline rs77283305 & 7:132593831 & $G / A$ & 0.69 & 0.015 & 0.003 & 3.91E-08 & 23 & 14387 & 0.70 & -0.037 & 0.028 & $1.78 \mathrm{E}-01$ & 0 & $9.80 \mathrm{E}-05$ \\
\hline rs10279261 & 7:133589846 & $\mathrm{G} / \mathrm{A}$ & 0.38 & 0.019 & 0.003 & $6.05 E-13$ & 23 & 14387 & 0.39 & -0.010 & 0.027 & 7.05E-01 & 0 & $1.68 \mathrm{E}-04$ \\
\hline rs4326350 & 8:10763655 & $\mathrm{C} / \mathrm{G}$ & 0.51 & 0.018 & 0.003 & $5.16 \mathrm{E}-12$ & 23 & 14387 & 0.53 & \multicolumn{5}{|c|}{ Excluded for MR } \\
\hline rs11783093 & $8: 27425349$ & $\mathrm{C} / \mathrm{T}$ & 0.84 & 0.047 & 0.003 & $2.07 \mathrm{E}-41$ & 23 & 14387 & 0.84 & -0.021 & 0.035 & 5.46E-01 & 21.5 & $5.91 \mathrm{E}-04$ \\
\hline rs7836565 & 8:52569449 & $\mathrm{C} / \mathrm{T}$ & 0.28 & 0.016 & 0.003 & 4.36E-08 & 23 & 14387 & 0.29 & $\underline{0.06} \underline{0}$ & 0.029 & 3.85E-02 & 0 & $9.74 \mathrm{E}-05$ \\
\hline rs13261666 & $8: 59814666$ & $\mathrm{G} / \mathrm{T}$ & 0.48 & 0.020 & 0.003 & $4.36 \mathrm{E}-15$ & 23 & 14387 & 0.48 & -0.019 & 0.026 & 4.64E-01 & 0 & 2.00E-04 \\
\hline rs3850736 & 8:64912021 & $\mathrm{G} / \mathrm{C}$ & 0.47 & 0.019 & 0.003 & $6.43 E-14$ & 23 & 14387 & 0.46 & \multicolumn{5}{|c|}{ Excluded for MR } \\
\hline rs2063976 & $8: 91096366$ & $\mathrm{C} / \mathrm{T}$ & 0.34 & 0.020 & 0.003 & $7.45 \mathrm{E}-14$ & 23 & 14387 & 0.34 & -0.019 & 0.027 & $4.81 \mathrm{E}-01$ & 0 & $1.81 \mathrm{E}-04$ \\
\hline rs6986430 & 8:93048104 & $\mathrm{T} / \mathrm{C}$ & 0.78 & 0.024 & 0.003 & $1.99 \mathrm{E}-15$ & 23 & 14387 & 0.77 & 0.019 & 0.030 & $5.26 \mathrm{E}-01$ & 0 & 2.05E-04 \\
\hline rs290601 & 8:115374642 & $\mathrm{T} / \mathrm{C}$ & 0.27 & 0.016 & 0.003 & $1.14 \mathrm{E}-08$ & 23 & 14387 & 0.27 & -0.003 & 0.029 & 9.19E-01 & 0 & 1.06E-04 \\
\hline rs3847244 & $9: 3025368$ & $\mathrm{~T} / \mathrm{C}$ & 0.47 & 0.019 & 0.003 & $2.60 \mathrm{E}-13$ & 23 & 14387 & 0.48 & -0.026 & 0.027 & 3.34E-01 & 0 & $1.74 \mathrm{E}-04$ \\
\hline rs11791671 & 9:3398679 & $\mathrm{T} / \mathrm{C}$ & 0.07 & 0.028 & 0.005 & 4.24E-08 & 23 & 14387 & 0.07 & 0.019 & 0.073 & 8.00E-01 & 35.7 & $9.74 \mathrm{E}-05$ \\
\hline rs7024924 & $9: 8282399$ & $\mathrm{C} / \mathrm{T}$ & 0.17 & 0.019 & 0.003 & $1.90 \mathrm{E}-08$ & 23 & 14387 & 0.17 & -0.004 & 0.034 & $9.18 \mathrm{E}-01$ & 0 & 1.03E-04 \\
\hline rs10966092 & $9: 23831658$ & $\mathrm{~T} / \mathrm{C}$ & 0.73 & 0.020 & 0.003 & $1.12 \mathrm{E}-12$ & 23 & 14387 & 0.74 & -0.023 & 0.029 & 4.35E-01 & 0 & 1.64E-04 \\
\hline rs4877285 & $9: 81354129$ & $G / A$ & 0.33 & 0.018 & 0.003 & $2.10 \mathrm{E}-11$ & 23 & 14387 & 0.36 & -0.052 & 0.028 & 5.89E-02 & 0 & 1.46E-04 \\
\hline rs2378662 & 9:86707289 & $A / G$ & 0.54 & 0.015 & 0.003 & 2.67E-09 & 23 & 14387 & 0.53 & -0.010 & 0.034 & 7.70E-01 & 28.6 & 1.15E-04 \\
\hline rs4837631 & $9: 122061948$ & $\mathrm{C} / \mathrm{T}$ & 0.55 & 0.015 & 0.003 & 2.03E-09 & 23 & 14387 & 0.58 & 0.022 & 0.027 & $4.08 \mathrm{E}-01$ & 0 & 1.17E-04 \\
\hline rs34553878 & 9:134334588 & $\mathrm{G} / \mathrm{A}$ & 0.11 & 0.025 & 0.004 & 1.17E-09 & 15 & 9465 & \multicolumn{6}{|c|}{ Excluded for MR } \\
\hline
\end{tabular}




\begin{tabular}{|c|c|c|c|c|c|c|c|c|c|c|c|c|c|c|}
\hline \multirow[b]{2}{*}{ SNP } & \multirow[b]{2}{*}{ Chr:Pos (GRCh37) } & \multirow[b]{2}{*}{ EA/BA } & \multicolumn{4}{|c|}{ Exposure } & \multicolumn{7}{|c|}{ Courage-PD } & \multirow[b]{2}{*}{$\mathbf{R}^{2}$} \\
\hline & & & EAF & Beta & SE & P-value & N studies & N samples & EAF & Beta & SE & P-value & $\left.\right|^{2}(\%)$ & \\
\hline rs10858334 & 9:137989785 & $\mathrm{G} / \mathrm{C}$ & 0.14 & 0.023 & 0.004 & 1.18E-09 & 23 & 14387 & 0.14 & -0.045 & 0.054 & $4.05 \mathrm{E}-01$ & 37.9 & $1.26 \mathrm{E}-04$ \\
\hline rs7920501 & $10: 10043159$ & $\mathrm{~T} / \mathrm{A}$ & 0.54 & 0.016 & 0.003 & $1.25 \mathrm{E}-09$ & 23 & 14387 & 0.53 & \multicolumn{5}{|c|}{ Excluded for MR } \\
\hline rs1291821 & $10: 11133823$ & $G / A$ & 0.53 & 0.014 & 0.003 & $1.39 \mathrm{E}-08$ & 23 & 14387 & 0.54 & -0.015 & 0.026 & $5.60 \mathrm{E}-01$ & 24.1 & 1.05E-04 \\
\hline rs7072776 & $10: 22032942$ & $A / G$ & 0.29 & 0.022 & 0.003 & $5.66 \mathrm{E}-15$ & 22 & 13367 & 0.33 & 0.011 & 0.030 & 7.11E-01 & 0 & $1.98 \mathrm{E}-04$ \\
\hline rs2796793 & $10: 36634124$ & $A / G$ & 0.45 & 0.014 & 0.003 & $1.55 \mathrm{E}-08$ & 22 & 13367 & 0.42 & 0.059 & 0.035 & 8.98E-02 & 29.8 & $1.04 \mathrm{E}-04$ \\
\hline rs 1733760 & $10: 56698174$ & $\mathrm{C} / \mathrm{T}$ & 0.51 & 0.015 & 0.003 & $6.70 \mathrm{E}-09$ & 23 & 14387 & 0.50 & 0.024 & 0.026 & $3.68 \mathrm{E}-01$ & 0 & $1.09 \mathrm{E}-04$ \\
\hline rs7921378 & 10:63674885 & $\mathrm{G} / \mathrm{C}$ & 0.52 & 0.023 & 0.003 & $6.10 \mathrm{E}-20$ & 23 & 14387 & 0.53 & \multicolumn{5}{|c|}{ Excluded for MR } \\
\hline rs11594623 & $10: 103960351$ & $\mathrm{C} / \mathrm{T}$ & 0.23 & 0.027 & 0.003 & $7.45 \mathrm{E}-20$ & 23 & 14387 & 0.21 & -0.067 & 0.031 & 3.24E-02 & 0 & 2.70E-04 \\
\hline rs12244388 & $10: 104640052$ & $A / G$ & 0.35 & 0.026 & 0.003 & 4.31E-22 & 23 & 14387 & 0.37 & -0.055 & 0.026 & 3.57E-02 & 0 & 3.03E-04 \\
\hline rs10885480 & $10: 115378364$ & $\mathrm{~T} / \mathrm{C}$ & 0.72 & 0.019 & 0.003 & $3.83 \mathrm{E}-11$ & 23 & 14387 & 0.73 & $\overline{-0.014}$ & 0.029 & $6.46 \mathrm{E}-01$ & 18.9 & $1.42 \mathrm{E}-04$ \\
\hline rs4752018 & $10: 118678712$ & $\mathrm{~A} / \mathrm{C}$ & 0.23 & 0.019 & 0.003 & $4.42 E-10$ & 23 & 14387 & 0.24 & -0.023 & 0.030 & 4.46E-01 & 21.6 & 1.26E-04 \\
\hline rs9423279 & $10: 125680419$ & $\mathrm{C} / \mathrm{G}$ & 0.36 & 0.019 & 0.003 & 3.06E-12 & 1 & 950 & \multicolumn{6}{|c|}{ Excluded for MR } \\
\hline$r s 6265^{a}$ & $11: 27679916$ & $\mathrm{C} / \mathrm{T}$ & 0.81 & 0.029 & 0.003 & $2.81 \mathrm{E}-19$ & 23 & 14387 & 0.79 & 0.038 & 0.032 & 2.44E-01 & 0 & 2.62E-04 \\
\hline rs2939756 & $11: 41436297$ & $G / A$ & 0.52 & 0.016 & 0.003 & $7.45 \mathrm{E}-10$ & 23 & 14387 & 0.56 & -0.007 & 0.026 & 7.96E-01 & 5.7 & $1.23 \mathrm{E}-04$ \\
\hline rs1381775 & $11: 42442826$ & $\mathrm{~T} / \mathrm{C}$ & 0.29 & 0.016 & 0.003 & $2.79 E-08$ & 23 & 14387 & 0.29 & -0.038 & 0.029 & $1.87 \mathrm{E}-01$ & 0 & $1.00 \mathrm{E}-04$ \\
\hline rs61886926 & $11: 64133552$ & $\mathrm{C} / \mathrm{T}$ & 0.62 & 0.018 & 0.003 & 7.30E-12 & 23 & 14387 & 0.64 & -0.004 & 0.035 & 9.05E-01 & 34.3 & $1.52 \mathrm{E}-04$ \\
\hline rs644740 & $11: 65561468$ & $\mathrm{C} / \mathrm{T}$ & 0.54 & 0.014 & 0.003 & 3.67E-08 & 23 & 14387 & 0.54 & -0.007 & 0.026 & 7.95E-01 & 0 & $9.84 \mathrm{E}-05$ \\
\hline rs7943721 & $11: 73309393$ & $G / A$ & 0.17 & 0.021 & 0.003 & $3.58 \mathrm{E}-10$ & \multicolumn{8}{|c|}{ NA in COURAGE-PD } \\
\hline rs7929518 & $11: 85980958$ & $G / A$ & 0.77 & 0.019 & 0.003 & $2.55 \mathrm{E}-10$ & 23 & 14387 & 0.77 & -0.062 & 0.038 & $1.10 \mathrm{E}-01$ & 27.6 & 1.30E-04 \\
\hline rs2155646 & $11: 112912811$ & $\mathrm{C} / \mathrm{T}$ & 0.40 & 0.038 & 0.003 & $9.44 \mathrm{E}-48$ & 23 & 14387 & 0.39 & -0.012 & 0.026 & 6.61E-01 & 0 & 6.85E-04 \\
\hline rs1713676a & $11: 113660576$ & $A / G$ & 0.48 & 0.017 & 0.003 & $5.38 \mathrm{E}-11$ & 23 & 14387 & 0.46 & 0.034 & 0.026 & $1.96 \mathrm{E}-01$ & 0 & $1.40 \mathrm{E}-04$ \\
\hline rs540860 & $11: 121530888$ & $\mathrm{G} / \mathrm{A}$ & 0.54 & 0.018 & 0.003 & $5.75 \mathrm{E}-12$ & 23 & 14387 & 0.52 & 0.038 & 0.026 & $1.40 \mathrm{E}-01$ & 0 & 1.54E-04 \\
\hline rs1106363 & $11: 131966264$ & $\mathrm{~T} / \mathrm{C}$ & 0.34 & 0.017 & 0.003 & $9.20 \mathrm{E}-11$ & 23 & 14387 & 0.37 & 0.013 & 0.026 & $6.14 \mathrm{E}-01$ & 0 & 1.36E-04 \\
\hline rs2010921 & 11:132098205 & $\mathrm{A} / \mathrm{G}$ & 0.31 & 0.017 & 0.003 & $2.47 \mathrm{E}-10$ & 23 & 14387 & 0.30 & 0.034 & 0.028 & $2.25 \mathrm{E}-01$ & 0 & 1.30E-04 \\
\hline rs11057005 & 12:16748721 & $A / G$ & 0.56 & 0.016 & 0.003 & $9.12 \mathrm{E}-10$ & 23 & 14387 & 0.58 & -0.034 & 0.038 & 3.73E-01 & 40 & $1.22 \mathrm{E}-04$ \\
\hline rs13906 & 12:49952394 & $\mathrm{C} / \mathrm{T}$ & 0.89 & 0.025 & 0.004 & 1.98E-09 & 23 & 14387 & 0.89 & 0.019 & 0.042 & 6.56E-01 & 0 & 1.17E-04 \\
\hline rs4759229 & $12: 56474480$ & $G / A$ & 0.66 & 0.016 & 0.003 & $6.53 \mathrm{E}-09$ & 22 & 14205 & 0.66 & $<0.001$ & 0.029 & $9.98 \mathrm{E}-01$ & 0 & $1.09 \mathrm{E}-04$ \\
\hline rs7969559 & $12: 69655167$ & $A / G$ & 0.29 & 0.017 & 0.003 & 1.53E-09 & 23 & 14387 & 0.34 & -0.016 & 0.028 & 5.67E-01 & 6.6 & $1.18 \mathrm{E}-04$ \\
\hline rs7134009 & 12:75263193 & $\mathrm{T} / \mathrm{C}$ & 0.71 & 0.016 & 0.003 & 4.30E-08 & 23 & 14387 & 0.70 & -0.015 & 0.028 & 5.96E-01 & 0 & 1.02E-04 \\
\hline rs77215829 & 12:112618346 & $A / C$ & 0.87 & 0.024 & 0.004 & $2.02 \mathrm{E}-10$ & 18 & 9799 & 0.87 & 0.005 & 0.051 & $9.25 \mathrm{E}-01$ & 16 & $1.32 \mathrm{E}-04$ \\
\hline rs1109480 & $12: 121083279$ & $\mathrm{G} / \mathrm{A}$ & 0.62 & 0.017 & 0.003 & $1.84 \mathrm{E}-10$ & 23 & 14387 & 0.62 & -0.030 & 0.027 & 2.63E-01 & 0 & 1.32E-04 \\
\hline rs11611651 & $12: 133380790$ & $A / G$ & 0.09 & 0.027 & 0.005 & 2.05E-09 & 23 & 14387 & 0.08 & -0.008 & 0.048 & $8.65 \mathrm{E}-01$ & 0 & 1.17E-04 \\
\hline rs17197663 & 13:38172867 & $G / A$ & 0.88 & 0.022 & 0.004 & 2.06E-08 & 23 & 14387 & 0.87 & 0.030 & 0.038 & 4.30E-01 & 23 & $1.02 \mathrm{E}-04$ \\
\hline rs4264267 & 13:38359676 & $\mathrm{T} / \mathrm{C}$ & 0.53 & 0.015 & 0.003 & 6.82E-09 & 23 & 14387 & 0.53 & -0.025 & 0.026 & $3.46 \mathrm{E}-01$ & 0 & $1.09 \mathrm{E}-04$ \\
\hline rs61959481 & 13:55834929 & $\mathrm{G} / \mathrm{A}$ & 0.79 & 0.020 & 0.003 & 7.95E-11 & 23 & 14387 & 0.79 & -0.022 & 0.032 & 4.94E-01 & 0 & 1.37E-04 \\
\hline rs55786907 & $13: 59871584$ & $G / A$ & 0.16 & 0.019 & 0.003 & 1.84E-08 & 23 & 14387 & 0.17 & 0.021 & 0.034 & 5.41E-01 & 0 & 1.03E-04 \\
\hline rs9540731a & 13:66949370 & $\mathrm{C} / \mathrm{T}$ & 0.49 & 0.018 & 0.003 & $3.42 \mathrm{E}-12$ & 23 & 14387 & 0.50 & -0.036 & 0.031 & $2.46 \mathrm{E}-01$ & 20.4 & $1.57 \mathrm{E}-04$ \\
\hline rs9545155 & 13:80191873 & $\mathrm{T} / \mathrm{C}$ & 0.52 & 0.016 & 0.003 & $3.04 \mathrm{E}-10$ & 23 & 14387 & 0.53 & -0.004 & 0.026 & $8.70 \mathrm{E}-01$ & 0 & $1.29 \mathrm{E}-04$ \\
\hline rs1772572 & 13:81191176 & $\mathrm{C} / \mathrm{A}$ & 0.68 & 0.017 & 0.003 & $5.62 E-10$ & 23 & 14387 & 0.68 & -0.045 & 0.027 & 9.54E-02 & 0 & 1.25E-04 \\
\hline rs1108130 & $13: 100648356$ & $\mathrm{~A} / \mathrm{T}$ & 0.21 & 0.024 & 0.003 & $1.57 \mathrm{E}-14$ & 23 & 14387 & 0.20 & -0.022 & 0.033 & 5.06E-01 & 0 & 1.92E-04 \\
\hline rs12878369 & 14:28346502 & $\mathrm{A} / \mathrm{C}$ & 0.41 & 0.017 & 0.003 & $1.60 \mathrm{E}-11$ & 23 & 14387 & 0.42 & -0.035 & 0.038 & 3.47E-01 & 42.9 & 1.48E-04 \\
\hline rs9323328a & $14: 58653514$ & $A / G$ & 0.46 & 0.014 & 0.003 & $2.55 \mathrm{E}-08$ & 23 & 14387 & 0.45 & 0.003 & 0.026 & $9.21 \mathrm{E}-01$ & 0 & $1.01 \mathrm{E}-04$ \\
\hline rs1811739 & $14: 77529375$ & $A / G$ & 0.25 & 0.018 & 0.003 & $5.97 \mathrm{E}-10$ & 23 & 14387 & 0.25 & 0.022 & 0.030 & 4.67E-01 & 0 & $1.25 \mathrm{E}-04$ \\
\hline rs8005334 & $14: 79563654$ & $\mathrm{G} / \mathrm{T}$ & 0.36 & 0.017 & 0.003 & $3.44 \mathrm{E}-10$ & 23 & 14387 & 0.35 & -0.016 & 0.027 & 5.55E-01 & 0 & $1.28 \mathrm{E}-04$ \\
\hline rs2925128 & $14: 98362355$ & $\mathrm{~T} / \mathrm{C}$ & 0.39 & 0.017 & 0.003 & $3.67 \mathrm{E}-10$ & 23 & 14387 & 0.38 & -0.028 & 0.040 & $4.90 \mathrm{E}-01$ & 48.2 & 1.34E-04 \\
\hline rs1381287 & $14: 98597552$ & $\mathrm{~T} / \mathrm{C}$ & 0.47 & 0.018 & 0.003 & $1.81 \mathrm{E}-12$ & 23 & 14387 & 0.49 & 0.020 & 0.026 & 4.39E-01 & 14.1 & $1.62 \mathrm{E}-04$ \\
\hline rs1435672 & 15:36399479 & $\mathrm{C} / \mathrm{T}$ & 0.56 & 0.014 & 0.003 & $3.82 E-08$ & 23 & 14387 & 0.54 & -0.018 & 0.026 & 4.95E-01 & 0 & $9.80 \mathrm{E}-05$ \\
\hline rs281296 & $15: 47685010$ & $A / G$ & 0.36 & 0.025 & 0.003 & $1.59 \mathrm{E}-20$ & 23 & 14387 & 0.37 & -0.046 & 0.027 & 9.02E-02 & 0 & 2.80E-04 \\
\hline
\end{tabular}




\begin{tabular}{|c|c|c|c|c|c|c|c|c|c|c|c|c|c|c|}
\hline \multirow[b]{2}{*}{ SNP } & \multirow[b]{2}{*}{ Chr:Pos (GRCh37) } & \multirow[b]{2}{*}{ EA/BA } & \multicolumn{4}{|c|}{ Exposure } & \multicolumn{7}{|c|}{ Courage-PD } & \multirow[b]{2}{*}{$\mathbf{R}^{2}$} \\
\hline & & & EAF & Beta & SE & P-value & N studies & N samples & EAF & Beta & SE & P-value & $\left.\right|^{2}(\%)$ & \\
\hline rs2289791 & $15: 67476952$ & $\mathrm{G} / \mathrm{T}$ & 0.75 & 0.018 & 0.003 & 2.01E-09 & 10 & 4792 & & \multicolumn{5}{|c|}{ Excluded for MR } \\
\hline rs62007780 & $15: 78025464$ & $\mathrm{G} / \mathrm{T}$ & 0.58 & 0.016 & 0.003 & $7.48 \mathrm{E}-10$ & 23 & 14387 & 0.60 & -0.002 & 0.026 & 9.37E-01 & 0 & 1.23E-04 \\
\hline rs4310804 & $15: 96858409$ & $\mathrm{C} / \mathrm{G}$ & 0.75 & 0.018 & 0.003 & $7.55 \mathrm{E}-10$ & 20 & 11001 & 0.77 & 0.029 & 0.038 & 4.46E-01 & 24.5 & 1.23E-04 \\
\hline rs1139897 & 16:720986 & $G / A$ & 0.77 & 0.024 & 0.003 & $1.77 \mathrm{E}-15$ & 22 & 14161 & 0.78 & 0.050 & 0.032 & $1.20 \mathrm{E}-01$ & 10.2 & 2.06E-04 \\
\hline rs11076962 & 16:5811367 & $\mathrm{C} / \mathrm{T}$ & 0.28 & 0.018 & 0.003 & $1.20 \mathrm{E}-10$ & 23 & 14387 & 0.26 & 0.010 & 0.029 & 7.27E-01 & 0 & $1.35 \mathrm{E}-04$ \\
\hline rs9922607 & $16: 17570220$ & $\mathrm{C} / \mathrm{T}$ & 0.80 & 0.022 & 0.003 & $3.42 E-12$ & 23 & 14387 & 0.80 & -0.014 & 0.033 & $6.66 \mathrm{E}-01$ & 0 & 1.57E-04 \\
\hline rs9941217 & 16:18050926 & $\mathrm{C} / \mathrm{G}$ & 0.65 & 0.019 & 0.003 & $3.50 \mathrm{E}-12$ & 23 & 14387 & 0.68 & 0.019 & 0.028 & 5.05E-01 & 20.7 & 1.57E-04 \\
\hline rs6497840 & $16: 25351633$ & $A / G$ & 0.71 & 0.023 & 0.003 & $2.01 \mathrm{E}-15$ & 23 & 14387 & 0.69 & -0.012 & 0.028 & $6.61 \mathrm{E}-01$ & 4.1 & $2.15 \mathrm{E}-04$ \\
\hline rs12918191 & $16: 50945156$ & $A / G$ & 0.76 & 0.020 & 0.003 & $3.14 \mathrm{E}-11$ & 23 & 14387 & 0.76 & -0.004 & 0.030 & 8.95E-01 & 0 & 1.43E-04 \\
\hline rs9302604 & $16: 69576894$ & $\mathrm{G} / \mathrm{A}$ & 0.44 & 0.019 & 0.003 & $3.29 E-13$ & 23 & 14387 & 0.44 & -0.016 & 0.033 & $6.41 \mathrm{E}-01$ & 26.3 & $1.72 \mathrm{E}-04$ \\
\hline rs117657830 & $16: 75766873$ & $A / G$ & 0.96 & 0.038 & 0.006 & 3.18E-09 & 23 & 14387 & 0.96 & 0.003 & 0.066 & $9.64 \mathrm{E}-01$ & 0 & 1.14E-04 \\
\hline rs 1050847 & $16: 87443734$ & $\mathrm{C} / \mathrm{T}$ & 0.44 & 0.015 & 0.003 & 7.37E-09 & 23 & 14387 & 0.49 & -0.013 & 0.026 & $6.21 \mathrm{E}-01$ & 11.3 & $1.08 \mathrm{E}-04$ \\
\hline rs11642231 & $16: 89608702$ & $G / A$ & 0.63 & 0.016 & 0.003 & $3.44 \mathrm{E}-09$ & 23 & 14387 & 0.68 & 0.072 & 0.028 & 1.06E-02 & 0 & 1.13E-04 \\
\hline rs4790874 & 17:1995177 & $\mathrm{T} / \mathrm{C}$ & 0.53 & 0.017 & 0.003 & $8.43 E-12$ & 23 & 14387 & 0.54 & -0.035 & 0.026 & 1.85E-01 & 0 & $1.52 \mathrm{E}-04$ \\
\hline rs28441558 & $17: 7803118$ & $\mathrm{~T} / \mathrm{C}$ & 0.94 & 0.036 & 0.006 & $1.24 \mathrm{E}-10$ & 16 & 9769 & \multicolumn{6}{|c|}{ Excluded for MR } \\
\hline rs67777803 & 17:27323322 & $\mathrm{G} / \mathrm{T}$ & 0.83 & 0.025 & 0.003 & $3.18 \mathrm{E}-13$ & 23 & 14387 & 0.84 & -0.014 & 0.035 & $6.79 \mathrm{E}-01$ & 4.8 & 1.72E-04 \\
\hline rs3764351 & $17: 37824339$ & $\mathrm{G} / \mathrm{A}$ & 0.34 & 0.015 & 0.003 & $3.89 E-08$ & 23 & 14387 & 0.37 & -0.033 & 0.028 & 2.34E-01 & 13.7 & $9.80 \mathrm{E}-05$ \\
\hline rs72836318 & $17: 44121579$ & $\mathrm{~T} / \mathrm{C}$ & 0.75 & 0.017 & 0.003 & 7.00E-09 & 23 & 14387 & 0.75 & -0.085 & 0.030 & 5.21E-03 & 0 & 1.09E-04 \\
\hline rs75919030 & $17: 50193197$ & $\mathrm{~T} / \mathrm{C}$ & 0.73 & 0.021 & 0.003 & $3.35 \mathrm{E}-13$ & 23 & 14387 & 0.74 & $\overline{0.003}$ & 0.029 & $9.27 \mathrm{E}-01$ & 0 & $1.72 \mathrm{E}-04$ \\
\hline rs2587507a & $17: 77790135$ & $\mathrm{~T} / \mathrm{C}$ & 0.50 & 0.015 & 0.003 & 8.69E-09 & 23 & 14382 & 0.52 & -0.042 & 0.026 & 9.96E-02 & 0 & 1.07E-04 \\
\hline rs34342129 & 18:5872472 & $\mathrm{T} / \mathrm{C}$ & 0.49 & 0.014 & 0.003 & $2.13 \mathrm{E}-08$ & 23 & 14387 & 0.50 & -0.038 & 0.026 & $1.45 \mathrm{E}-01$ & 0 & 1.02E-04 \\
\hline rs4476253 & $18: 25253297$ & $G / A$ & 0.76 & 0.018 & 0.003 & $5.78 \mathrm{E}-10$ & 23 & 14387 & 0.76 & 0.014 & 0.038 & 7.14E-01 & 26.8 & $1.25 \mathrm{E}-04$ \\
\hline rs8096225 & 18:36921851 & $\mathrm{C} / \mathrm{A}$ & 0.70 & 0.016 & 0.003 & 2.63E-08 & 23 & 14387 & 0.70 & -0.006 & 0.028 & 8.23E-01 & 1.4 & $1.01 \mathrm{E}-04$ \\
\hline rs67050670 & $18: 39297254$ & $\mathrm{~A} / \mathrm{G}$ & 0.77 & 0.020 & 0.003 & $2.34 \mathrm{E}-11$ & 23 & 14387 & 0.74 & 0.051 & 0.030 & 8.56E-02 & 14.6 & $1.45 \mathrm{E}-04$ \\
\hline rs1373178 & $18: 49967811$ & $\mathrm{~T} / \mathrm{G}$ & 0.41 & 0.020 & 0.003 & $4.16 \mathrm{E}-15$ & 23 & 14387 & 0.42 & -0.023 & 0.026 & 3.87E-01 & 0 & $2.00 \mathrm{E}-04$ \\
\hline rs72938304 & $18: 53661743$ & $G / A$ & 0.89 & 0.027 & 0.004 & $1.36 \mathrm{E}-11$ & 23 & 14387 & 0.88 & 0.051 & 0.041 & $2.12 \mathrm{E}-01$ & 18.7 & $1.48 \mathrm{E}-04$ \\
\hline rs71367544 & 18:77574374 & $\mathrm{T} / \mathrm{C}$ & 0.20 & 0.021 & 0.003 & $8.54 \mathrm{E}-11$ & 23 & 14387 & 0.17 & 0.025 & 0.034 & 4.58E-01 & 0 & 1.37E-04 \\
\hline rs76608582 & 19:4474725 & $\mathrm{C} / \mathrm{A}$ & 0.95 & 0.035 & 0.006 & 4.88E-09 & \multicolumn{8}{|c|}{ NA in COURAGE-PD } \\
\hline rs10853981 & $19: 4965064$ & $A / G$ & 0.33 & 0.015 & 0.003 & 4.88E-08 & 23 & 14387 & 0.31 & -0.016 & 0.028 & 5.72E-01 & 1.9 & 9.67E-05 \\
\hline rs113230003 & $19: 18460956$ & $G / A$ & 0.74 & 0.019 & 0.003 & $1.05 \mathrm{E}-10$ & 23 & 14387 & 0.76 & 0.055 & 0.031 & 7.61E-02 & 0 & $1.35 \mathrm{E}-04$ \\
\hline rs117734003 & $19: 51129745$ & $\mathrm{C} / \mathrm{G}$ & 0.07 & 0.030 & 0.005 & 2.57E-09 & 15 & 8384 & \multicolumn{6}{|c|}{ Excluded for MR } \\
\hline rs1126757a & $19: 55879872$ & $\mathrm{~T} / \mathrm{C}$ & 0.47 & 0.014 & 0.003 & $2.92 E-08$ & 23 & 14369 & 0.47 & -0.001 & 0.029 & $9.68 \mathrm{E}-01$ & 12.9 & $1.00 \mathrm{E}-04$ \\
\hline rs6050446 & $20: 25195509$ & $\mathrm{G} / \mathrm{A}$ & 0.97 & 0.054 & 0.008 & $8.80 E-13$ & 18 & 12644 & 0.98 & -0.070 & 0.091 & 4.42E-01 & 0 & $2.81 \mathrm{E}-04$ \\
\hline rs6073075 & $20: 42015801$ & $\mathrm{~T} / \mathrm{A}$ & 0.18 & 0.019 & 0.003 & $2.44 \mathrm{E}-08$ & 23 & 14387 & 0.20 & -0.008 & 0.033 & 8.05E-01 & 4.9 & $1.01 \mathrm{E}-04$ \\
\hline rs3810496 & $20: 62406886$ & $\mathrm{C} / \mathrm{T}$ & 0.62 & 0.016 & 0.003 & $1.54 \mathrm{E}-09$ & 22 & 14205 & 0.63 & -0.047 & 0.042 & $2.61 \mathrm{E}-01$ & 44.2 & 1.19E-04 \\
\hline rs4818005 & $21: 40588819$ & $G / A$ & 0.42 & 0.020 & 0.003 & $1.09 \mathrm{E}-14$ & 23 & 14387 & 0.43 & -0.036 & 0.026 & $1.70 \mathrm{E}-01$ & 0 & 2.03E-04 \\
\hline rs4822102 & $22: 42698430$ & $\mathrm{C} / \mathrm{T}$ & 0.38 & 0.017 & 0.003 & $2.78 \mathrm{E}-10$ & 23 & 14387 & 0.38 & 0.022 & 0.036 & 5.34E-01 & 33.4 & $1.29 \mathrm{E}-04$ \\
\hline
\end{tabular}

NA, not available; EA/BA, effect allele/base allele; EAF, effect allele frequency; SE, standard error.

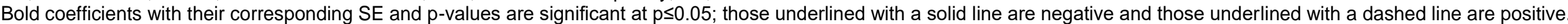

$R^{2}$ is the proportion of the variance of the exposure explained by the genetic variant according to the formula: $2 \times B_{\text {Betaexposure }} \times E A F_{\text {exposure }} \times\left(1-E A F_{\text {exposure }}\right)$.

a SNPs genotyped.

b SNPs associated with both alcohol and coffee consumption.

c Proxy SNP used in Courage-PD: rs61857951.

d Proxy SNP used in Courage-PD: rs117495226. 
Supplementary table 4: SNPs used for Mendelian randomization analyses: individual associations with PD stratified by age and disease duration.

\begin{tabular}{|c|c|c|c|c|c|c|c|c|c|c|c|c|c|}
\hline \multirow[b]{2}{*}{ SNP } & \multirow[b]{2}{*}{ EA/BA } & \multicolumn{3}{|c|}{$\begin{array}{c}\text { Age } \leq 67 y \\
\text { (2,878 cases; } 2,944 \text { controls) }\end{array}$} & \multicolumn{3}{|c|}{$\begin{array}{c}\text { Age }>67 y \\
(3,208 \text { cases; } 2,728 \text { controls })\end{array}$} & \multicolumn{3}{|c|}{$\begin{array}{c}\text { PD duration } \leq 7 y \\
(3,633 \text { cases; } 6,836 \text { controls })\end{array}$} & \multicolumn{3}{|c|}{$\begin{array}{c}\text { PD duration }>7 y \\
(3,271 \text { cases; } 6,836 \text { controls })\end{array}$} \\
\hline & & Beta & SE & P-value & Beta & SE & P-value & Beta & SE & P-value & Beta & SE & P-value \\
\hline \multicolumn{14}{|c|}{ Alcohol drinking (per 1-SD increase of In(drinks per week)) } \\
\hline rs705687 & $\mathrm{G} / \mathrm{A}$ & 0.024 & 0.051 & $6.36 \mathrm{E}-01$ & -0.013 & 0.052 & 8.09E-01 & 0.033 & 0.040 & 4.07E-01 & 0.037 & 0.042 & 3.81E-01 \\
\hline rs58107686 & $\mathrm{A} / \mathrm{C}$ & -0.014 & 0.043 & 7.42E-01 & 0.014 & 0.043 & 7.40E-01 & 0.031 & 0.033 & $3.60 \mathrm{E}-01$ & -0.010 & 0.036 & 7.72E-01 \\
\hline rs12088813 & $\mathrm{C} / \mathrm{A}$ & -0.024 & 0.065 & 7.11E-01 & 0.026 & 0.046 & $5.80 \mathrm{E}-01$ & 0.042 & 0.036 & 2.36E-01 & 0.045 & 0.038 & $2.41 \mathrm{E}-01$ \\
\hline rs5024204 & $\mathrm{A} / \mathrm{T}$ & 0.088 & 0.045 & $5.11 \mathrm{E}-02$ & 0.012 & 0.046 & 7.90E-01 & 0.042 & 0.035 & $2.30 \mathrm{E}-01$ & $\underline{0.080}$ & 0.037 & 3.34E-02 \\
\hline rs 10753661 & $\mathrm{~A} / \mathrm{G}$ & 0.026 & 0.045 & $5.65 \mathrm{E}-01$ & 0.080 & 0.045 & 7.70E-02 & 0.032 & 0.035 & $3.65 \mathrm{E}-01$ & 0.026 & 0.037 & 4.90E-01 \\
\hline rs28680958 & $A / G$ & -0.013 & 0.049 & 7.83E-01 & 0.012 & 0.049 & 8.09E-01 & -0.007 & 0.038 & 8.60E-01 & 0.019 & 0.040 & 6.39E-01 \\
\hline rs823114 & $G / A$ & -0.082 & 0.041 & 4.63E-02 & 0.002 & 0.042 & $9.71 \mathrm{E}-01$ & -0.015 & 0.033 & $6.48 \mathrm{E}-01$ & -0.064 & 0.035 & $6.42 \mathrm{E}-02$ \\
\hline rs77165542 & $\mathrm{T} / \mathrm{C}$ & \multicolumn{12}{|c|}{ Excluded for MR } \\
\hline rs1260326 & $\mathrm{T} / \mathrm{C}$ & -0.103 & 0.042 & 1.35E-02 & -0.072 & 0.042 & 8.51E-02 & -0.075 & 0.032 & 2.05E-02 & -0.070 & 0.035 & 4.42E-02 \\
\hline rs13383034 & $\mathrm{C} / \mathrm{T}$ & $\overline{-0.033}$ & 0.044 & 4.49E-01 & $\underline{-0.088}$ & 0.044 & 4.66E-02 & -0.077 & 0.034 & 2.46E-02 & $\overline{-0.029}$ & 0.036 & 4.18E-01 \\
\hline rs13032049 & $\mathrm{A} / \mathrm{G}$ & 0.049 & 0.044 & 2.67E-01 & $\overline{0.069}$ & 0.046 & $1.30 \mathrm{E}-01$ & $\overline{0.037}$ & 0.045 & 4.12E-01 & 0.055 & 0.038 & 1.44E-01 \\
\hline rs828867 & $\mathrm{G} / \mathrm{A}$ & \multirow{2}{*}{\multicolumn{12}{|c|}{$\begin{array}{l}\text { Excluded for MR } \\
\text { NA in COURAGE-PD }\end{array}$}} \\
\hline rs11692435 & $\mathrm{G} / \mathrm{A}$ & & & & & & & & & & & & \\
\hline rs 13024996 & $\mathrm{~A} / \mathrm{C}$ & 0.064 & 0.043 & $1.30 \mathrm{E}-01$ & -0.005 & 0.043 & $9.10 \mathrm{E}-01$ & 0.010 & 0.033 & 7.54E-01 & 0.022 & 0.035 & 5.37E-01 \\
\hline rs72859280 & $\mathrm{G} / \mathrm{T}$ & \multicolumn{6}{|c|}{ Excluded for MR } & -0.134 & 0.104 & 1.97E-01 & -0.147 & 0.105 & $1.62 \mathrm{E}-01$ \\
\hline rs56337305 & $\mathrm{C} / \mathrm{T}$ & -0.045 & 0.042 & 2.84E-01 & -0.014 & 0.042 & 7.34E-01 & 0.005 & 0.033 & $8.76 \mathrm{E}-01$ & -0.039 & 0.035 & 2.64E-01 \\
\hline rs13094887 & $\mathrm{T} / \mathrm{A}$ & 0.013 & 0.043 & 7.72E-01 & -0.101 & 0.044 & 2.26E-02 & -0.033 & 0.034 & 3.35E-01 & -0.035 & 0.037 & 3.34E-01 \\
\hline rs62250685 & $\mathrm{G} / \mathrm{A}$ & -0.036 & 0.041 & $3.82 E-01$ & -0.014 & 0.042 & 7.39E-01 & 0.012 & 0.032 & 7.06E-01 & -0.048 & 0.034 & $1.61 \mathrm{E}-01$ \\
\hline rs9838144 & $\mathrm{C} / \mathrm{G}$ & -0.075 & 0.070 & 2.86E-01 & -0.053 & 0.070 & 4.47E-01 & -0.029 & 0.041 & $4.74 \mathrm{E}-01$ & $\underline{-0.099}$ & 0.042 & 2.04E-02 \\
\hline rs2011092 & $\mathrm{C} / \mathrm{T}$ & -0.037 & 0.045 & 4.08E-01 & 0.036 & 0.060 & $5.50 \mathrm{E}-01$ & 0.026 & 0.035 & 4.49E-01 & $\overline{-0.054}$ & 0.037 & 1.40E-01 \\
\hline rs6787172 & $\mathrm{G} / \mathrm{T}$ & 0.047 & 0.040 & $2.48 \mathrm{E}-01$ & 0.019 & 0.041 & 6.35E-01 & 0.012 & 0.031 & 6.94E-01 & 0.044 & 0.034 & $1.88 \mathrm{E}-01$ \\
\hline rs3748034 & $\mathrm{T} / \mathrm{G}$ & -0.071 & 0.061 & 2.44E-01 & 0.038 & 0.060 & 5.24E-01 & 0.003 & 0.047 & 9.51E-01 & 0.009 & 0.049 & 8.53E-01 \\
\hline rs11940694 & $\mathrm{A} / \mathrm{G}$ & -0.016 & 0.058 & $7.86 \mathrm{E}-01$ & -0.029 & 0.042 & $4.92 \mathrm{E}-01$ & -0.017 & 0.039 & $6.54 \mathrm{E}-01$ & -0.020 & 0.034 & 5.65E-01 \\
\hline rs4501255 & $\mathrm{C} / \mathrm{G}$ & -0.017 & 0.072 & 8.12E-01 & -0.024 & 0.050 & $6.24 \mathrm{E}-01$ & 0.005 & 0.038 & 8.99E-01 & -0.063 & 0.041 & $1.29 \mathrm{E}-01$ \\
\hline rs1229984 & $\mathrm{T} / \mathrm{C}$ & -0.092 & 0.083 & $2.70 \mathrm{E}-01$ & 0.023 & 0.086 & 7.90E-01 & 0.022 & 0.098 & 8.23E-01 & -0.056 & 0.077 & 4.66E-01 \\
\hline rs2165670 & $G / A$ & 0.019 & 0.075 & 7.99E-01 & 0.114 & 0.118 & 3.33E-01 & \multicolumn{3}{|c|}{ Excluded for MR } & 0.008 & 0.059 & 8.92E-01 \\
\hline rs 13107325 & $\mathrm{~T} / \mathrm{C}$ & -0.221 & 0.081 & $6.28 E-03$ & -0.012 & 0.093 & 8.95E-01 & $\underline{-0.122}$ & 0.062 & 4.81E-02 & -0.040 & 0.068 & 5.58E-01 \\
\hline rs 4690727 & $\mathrm{C} / \mathrm{G}$ & -0.016 & 0.045 & $7.21 \mathrm{E}-01$ & -0.016 & 0.046 & 7.30E-01 & -0.043 & 0.035 & $2.22 \mathrm{E}-01$ & 0.043 & 0.038 & $2.52 \mathrm{E}-01$ \\
\hline rs12651313 & $\mathrm{G} / \mathrm{C}$ & \multicolumn{12}{|c|}{ Excluded for MR } \\
\hline rs4916723 & $\mathrm{C} / \mathrm{A}$ & -0.051 & 0.056 & 3.56E-01 & -0.056 & 0.044 & 1.97E-01 & -0.023 & 0.034 & 4.87E-01 & -0.056 & 0.036 & 1.13E-01 \\
\hline rs12655091 & $A / G$ & -0.013 & 0.041 & 7.56E-01 & 0.005 & 0.053 & $9.24 \mathrm{E}-01$ & -0.035 & 0.032 & $2.76 \mathrm{E}-01$ & -0.022 & 0.034 & $5.24 \mathrm{E}-01$ \\
\hline rs55872084 & $\mathrm{G} / \mathrm{T}$ & 0.085 & 0.050 & $9.28 \mathrm{E}-02$ & -0.014 & 0.051 & 7.87E-01 & 0.019 & 0.039 & $6.35 \mathrm{E}-01$ & -0.021 & 0.041 & 6.17E-01 \\
\hline rs6460047 & $\mathrm{T} / \mathrm{C}$ & 0.019 & 0.053 & 7.27E-01 & -0.001 & 0.069 & 9.93E-01 & -0.003 & 0.041 & $9.41 \mathrm{E}-01$ & -0.034 & 0.043 & 4.23E-01 \\
\hline rs10236149 & $\mathrm{G} / \mathrm{A}$ & 0.058 & 0.060 & $3.29 E-01$ & 0.039 & 0.061 & $5.15 \mathrm{E}-01$ & 0.086 & 0.046 & $6.46 \mathrm{E}-02$ & 0.045 & 0.051 & 3.77E-01 \\
\hline rs35034355 & $A / G$ & 0.009 & 0.040 & 8.24E-01 & -0.015 & 0.041 & 7.19E-01 & -0.011 & 0.032 & 7.22E-01 & -0.013 & 0.034 & 7.10E-01 \\
\hline rs6951574 & $\mathrm{T} / \mathrm{C}$ & -0.007 & 0.042 & $8.71 \mathrm{E}-01$ & -0.008 & 0.042 & $8.42 \mathrm{E}-01$ & -0.030 & 0.033 & $3.52 \mathrm{E}-01$ & 0.030 & 0.035 & 3.87E-01 \\
\hline rs 13250583 & $\mathrm{~T} / \mathrm{C}$ & -0.022 & 0.052 & $6.80 \mathrm{E}-01$ & -0.009 & 0.053 & 8.68E-01 & -0.018 & 0.041 & $6.55 \mathrm{E}-01$ & -0.009 & 0.043 & 8.37E-01 \\
\hline rs1217091 & $\mathrm{T} / \mathrm{C}$ & 0.049 & 0.052 & $3.51 \mathrm{E}-01$ & 0.090 & 0.054 & 9.42E-02 & $\underline{0} .09 \underline{0}$ & 0.041 & 2.72E-02 & 0.063 & 0.043 & $1.45 \mathrm{E}-01$ \\
\hline rs28601761 & $\mathrm{C} / \mathrm{G}$ & \multicolumn{12}{|c|}{ Excluded for MR } \\
\hline rs55932213 & $\mathrm{A} / \mathrm{G}$ & -0.051 & 0.048 & 2.87E-01 & 0.002 & 0.049 & $9.70 \mathrm{E}-01$ & -0.014 & 0.037 & 7.17E-01 & -0.020 & 0.040 & $6.15 \mathrm{E}-01$ \\
\hline rs 10978550 & $\mathrm{C} / \mathrm{T}$ & 0.017 & 0.052 & 7.39E-01 & 0.004 & 0.071 & $9.50 \mathrm{E}-01$ & 0.008 & 0.045 & 8.54E-01 & 0.028 & 0.042 & 5.09E-01 \\
\hline rs7074871 & $A / G$ & 0.014 & 0.068 & $8.41 \mathrm{E}-01$ & 0.001 & 0.047 & $9.81 \mathrm{E}-01$ & 0.033 & 0.036 & $3.65 \mathrm{E}-01$ & -0.013 & 0.039 & 7.35E-01 \\
\hline rs17665139 & $\mathrm{T} / \mathrm{C}$ & 0.033 & 0.059 & $5.78 \mathrm{E}-01$ & 0.002 & 0.058 & $9.68 \mathrm{E}-01$ & 0.061 & 0.058 & $2.91 \mathrm{E}-01$ & -0.039 & 0.049 & 4.30E-01 \\
\hline rs7950166 & $\mathrm{T} / \mathrm{C}$ & -0.039 & 0.042 & $3.50 \mathrm{E}-01$ & 0.011 & 0.043 & 7.96E-01 & -0.020 & 0.042 & $6.35 \mathrm{E}-01$ & -0.038 & 0.035 & 2.74E-01 \\
\hline
\end{tabular}




\begin{tabular}{|c|c|c|c|c|c|c|c|c|c|c|c|c|c|}
\hline \multirow[b]{2}{*}{ SNP } & \multirow[b]{2}{*}{ EA/BA } & \multicolumn{3}{|c|}{$\begin{array}{c}\text { Age } \leq 67 y \\
\text { (2,878 cases; } 2,944 \text { controls })\end{array}$} & \multicolumn{3}{|c|}{$\begin{array}{c}\text { Age }>67 y \\
\text { (3,208 cases; } 2,728 \text { controls })\end{array}$} & \multicolumn{3}{|c|}{$\begin{array}{c}\text { PD duration } \leq 7 y \\
\text { (3,633 cases; } 6,836 \text { controls) }\end{array}$} & \multicolumn{3}{|c|}{$\begin{array}{c}\text { PD duration }>7 y \\
(3,271 \text { cases; } 6,836 \text { controls })\end{array}$} \\
\hline & & Beta & SE & P-value & Beta & SE & P-value & Beta & SE & P-value & Beta & SE & P-value \\
\hline rs11030084 & $\mathrm{T} / \mathrm{C}$ & -0.059 & 0.051 & $2.48 \mathrm{E}-01$ & 0.020 & 0.052 & 7.04E-01 & -0.031 & 0.040 & $4.42 \mathrm{E}-01$ & -0.024 & 0.043 & 5.80E-01 \\
\hline rs56030824 & $\mathrm{A} / \mathrm{G}$ & 0.016 & 0.043 & 7.06E-01 & $<0.001$ & 0.044 & 9.92E-01 & $<0.001$ & 0.048 & 9.94E-01 & 0.050 & 0.036 & 1.63E-01 \\
\hline rs10750025 & $\mathrm{C} / \mathrm{T}$ & 0.008 & 0.045 & 8.67E-01 & -0.056 & 0.044 & 2.02E-01 & -0.025 & 0.034 & 4.62E-01 & 0.004 & 0.040 & $9.13 \mathrm{E}-01$ \\
\hline rs4938230 & $\mathrm{C} / \mathrm{A}$ & \multicolumn{12}{|c|}{ Excluded for MR } \\
\hline rs682011 & $\mathrm{T} / \mathrm{C}$ & -0.053 & 0.041 & 1.99E-01 & -0.012 & 0.041 & 7.72E-01 & -0.038 & 0.035 & $2.73 E-01$ & -0.017 & 0.034 & $6.14 \mathrm{E}-01$ \\
\hline rs12795042 & $\mathrm{C} / \mathrm{A}$ & -0.002 & 0.044 & $9.60 \mathrm{E}-01$ & -0.034 & 0.044 & 4.40E-01 & 0.018 & 0.034 & 6.06E-01 & -0.043 & 0.036 & 2.34E-01 \\
\hline rs3809162 & $\mathrm{A} / \mathrm{G}$ & -0.014 & 0.043 & 7.52E-01 & -0.034 & 0.044 & 4.38E-01 & -0.054 & 0.034 & 1.10E-01 & 0.010 & 0.046 & 8.30E-01 \\
\hline rs10506274 & $\mathrm{T} / \mathrm{G}$ & 0.054 & 0.041 & $1.84 \mathrm{E}-01$ & -0.013 & 0.041 & $7.55 \mathrm{E}-01$ & 0.036 & 0.032 & 2.53E-01 & -0.013 & 0.034 & 7.10E-01 \\
\hline rs4842786 & $A / G$ & -0.020 & 0.042 & $6.27 \mathrm{E}-01$ & 0.012 & 0.043 & 7.80E-01 & 0.002 & 0.033 & 9.57E-01 & -0.002 & 0.035 & $9.52 \mathrm{E}-01$ \\
\hline rs500321 & $\mathrm{T} / \mathrm{A}$ & $<0.001$ & 0.046 & $9.98 \mathrm{E}-01$ & 0.026 & 0.048 & $5.91 \mathrm{E}-01$ & 0.037 & 0.036 & 3.03E-01 & -0.045 & 0.039 & $2.50 \mathrm{E}-01$ \\
\hline rs1123285 & $\mathrm{G} / \mathrm{C}$ & 0.024 & 0.064 & 7.06E-01 & -0.066 & 0.044 & 1.34E-01 & -0.059 & 0.034 & 8.19E-02 & 0.002 & 0.036 & 9.56E-01 \\
\hline rs28929474 & $\mathrm{T} / \mathrm{C}$ & \multicolumn{12}{|c|}{ Excluded for MR } \\
\hline rs2472297 & $\mathrm{C} / \mathrm{T}$ & -0.022 & 0.056 & 6.93E-01 & -0.011 & 0.072 & 8.75E-01 & -0.077 & 0.046 & 9.74E-02 & -0.021 & 0.045 & $6.43 \mathrm{E}-01$ \\
\hline rs12907323 & $A / G$ & -0.016 & 0.041 & $6.94 \mathrm{E}-01$ & 0.039 & 0.042 & $3.51 \mathrm{E}-01$ & 0.045 & 0.032 & $1.65 E-01$ & -0.010 & 0.034 & 7.59E-01 \\
\hline rs17177078 & $\mathrm{T} / \mathrm{C}$ & -0.035 & 0.074 & $6.35 \mathrm{E}-01$ & -0.001 & 0.079 & $9.90 \mathrm{E}-01$ & -0.020 & 0.059 & 7.30E-01 & -0.015 & 0.064 & 8.18E-01 \\
\hline rs378421 & $A / G$ & -0.036 & 0.043 & 4.02E-01 & 0.006 & 0.043 & 8.93E-01 & -0.034 & 0.033 & 3.07E-01 & -0.038 & 0.035 & 2.76E-01 \\
\hline rs62044525 & $\mathrm{G} / \mathrm{C}$ & $\underline{0} .119$ & 0.053 & 2.42E-02 & 0.071 & 0.053 & $1.81 \mathrm{E}-01$ & $\underline{0.09} \underline{8}$ & 0.041 & $1.76 \mathrm{E}-02$ & 0.053 & 0.044 & 2.27E-01 \\
\hline rs1104608 & $\mathrm{C} / \mathrm{G}$ & \multicolumn{12}{|c|}{ Excluded for MR } \\
\hline rs4548913 & $\mathrm{A} / \mathrm{G}$ & -0.019 & 0.042 & $6.57 \mathrm{E}-01$ & 0.024 & 0.044 & 5.87E-01 & 0.005 & 0.048 & $9.21 \mathrm{E}-01$ & -0.046 & 0.035 & $1.98 \mathrm{E}-01$ \\
\hline rs3803800 & $A / G$ & 0.037 & 0.053 & $4.91 \mathrm{E}-01$ & -0.004 & 0.052 & $9.40 \mathrm{E}-01$ & 0.018 & 0.050 & $7.18 \mathrm{E}-01$ & -0.001 & 0.043 & $9.75 E-01$ \\
\hline rs2854334 & $A / G$ & \multicolumn{6}{|c|}{ Excluded for MR } & $0.07 \underline{6}$ & 0.037 & 4.14E-02 & -0.018 & 0.039 & $6.37 \mathrm{E}-01$ \\
\hline rs10438820 & $\mathrm{C} / \mathrm{T}$ & $\underline{0.08} \underline{8}$ & 0.044 & 4.55E-02 & 0.019 & 0.046 & $6.78 \mathrm{E}-01$ & $\overline{0.02 \overline{7}}$ & 0.035 & $4.48 \mathrm{E}-01$ & 0.061 & 0.037 & 1.00E-01 \\
\hline rs9950000 & $\mathrm{T} / \mathrm{C}$ & -0.023 & 0.041 & 5.82E-01 & -0.011 & 0.042 & 7.96E-01 & -0.040 & 0.032 & 2.18E-01 & 0.019 & 0.035 & 5.89E-01 \\
\hline rs4092465 & $G / A$ & \multicolumn{12}{|c|}{ NA in COURAGE-PD } \\
\hline rs281379 & $\mathrm{G} / \mathrm{A}$ & 0.052 & 0.058 & 3.67E-01 & 0.038 & 0.042 & 3.57E-01 & 0.054 & 0.032 & $9.22 \mathrm{E}-02$ & -0.013 & 0.034 & 6.96E-01 \\
\hline rs4815364 & $G / A$ & 0.042 & 0.043 & 3.27E-01 & 0.063 & 0.043 & $1.48 \mathrm{E}-01$ & 0.050 & 0.033 & $1.33 \mathrm{E}-01$ & 0.011 & 0.036 & 7.65E-01 \\
\hline rs9607814 & $\mathrm{A} / \mathrm{C}$ & $\underline{-0.162}$ & 0.051 & 1.56E-03 & $\underline{-0.116}$ & 0.051 & 2.41E-02 & $\underline{-0.118}$ & 0.040 & 3.19E-03 & $\underline{-0.144}$ & 0.058 & 1.34E-02 \\
\hline \multicolumn{14}{|c|}{ Coffee drinking (per In(cups per day)) } \\
\hline rs574367 & $T / G$ & -0.105 & 0.077 & $1.73 \mathrm{E}-01$ & -0.094 & 0.055 & 8.85E-02 & -0.148 & 0.061 & 1.43E-02 & -0.103 & 0.061 & 9.03E-02 \\
\hline rs 10865548 & $\mathrm{G} / \mathrm{A}$ & -0.037 & 0.052 & 4.76E-01 & 0.083 & 0.072 & $2.48 \mathrm{E}-01$ & $\overline{-0.005}$ & 0.040 & $9.10 \mathrm{E}-01$ & 0.032 & 0.044 & 4.66E-01 \\
\hline rs1260326 & $\mathrm{C} / \mathrm{T}$ & $\underline{0.103}$ & 0.042 & 1.35E-02 & 0.072 & 0.042 & 8.51E-02 & $\underline{0.075}$ & 0.032 & 2.05E-02 & $\underline{0.070}$ & 0.035 & 4.42E-02 \\
\hline rs4410790 & $\mathrm{C} / \mathrm{T}$ & -0.027 & 0.042 & 5.17E-01 & 0.008 & 0.043 & 8.48E-01 & -0.030 & 0.044 & 4.94E-01 & -0.008 & 0.035 & 8.24E-01 \\
\hline rs34060476 & $\mathrm{G} / \mathrm{A}$ & 0.067 & 0.066 & 3.07E-01 & 0.002 & 0.066 & $9.76 \mathrm{E}-01$ & 0.020 & 0.052 & $6.95 \mathrm{E}-01$ & 0.082 & 0.053 & 1.18E-01 \\
\hline rs1057868 & $\mathrm{T} / \mathrm{C}$ & 0.005 & 0.061 & $9.28 \mathrm{E}-01$ & 0.031 & 0.045 & 4.86E-01 & 0.019 & 0.035 & 5.93E-01 & 0.031 & 0.037 & 4.02E-01 \\
\hline rs597045 & $A / T$ & 0.011 & 0.044 & 7.99E-01 & -0.015 & 0.045 & 7.39E-01 & -0.039 & 0.050 & $4.40 \mathrm{E}-01$ & 0.006 & 0.037 & 8.64E-01 \\
\hline rs1956218 & $G / A$ & -0.048 & 0.041 & $2.45 \mathrm{E}-01$ & 0.002 & 0.041 & $9.61 \mathrm{E}-01$ & -0.036 & 0.032 & $2.59 \mathrm{E}-01$ & -0.026 & 0.034 & 4.51E-01 \\
\hline rs2472297 & $\mathrm{T} / \mathrm{C}$ & 0.022 & 0.056 & 6.93E-01 & 0.011 & 0.072 & 8.75E-01 & 0.077 & 0.046 & $9.74 \mathrm{E}-02$ & 0.021 & 0.045 & 6.43E-01 \\
\hline rs66723169 & $\mathrm{A} / \mathrm{C}$ & -0.004 & 0.049 & $9.38 \mathrm{E}-01$ & -0.057 & 0.050 & 2.53E-01 & 0.005 & 0.038 & 8.91E-01 & -0.057 & 0.041 & $1.64 \mathrm{E}-01$ \\
\hline rs2330783 & $\mathrm{G} / \mathrm{T}$ & \multicolumn{12}{|c|}{ Excluded for MR } \\
\hline \multicolumn{14}{|c|}{ Lifetime smoking index } \\
\hline rs1193237 & $\mathrm{C} / \mathrm{G}$ & \multicolumn{12}{|c|}{ Excluded for MR } \\
\hline rs4949465 & $\mathrm{C} / \mathrm{T}$ & -0.007 & 0.064 & $9.13 \mathrm{E}-01$ & 0.004 & 0.064 & $9.54 \mathrm{E}-01$ & 0.016 & 0.049 & 7.50E-01 & 0.010 & 0.052 & 8.48E-01 \\
\hline rs549845 & $\mathrm{G} / \mathrm{A}$ & -0.102 & 0.066 & 1.19E-01 & 0.030 & 0.045 & $5.05 E-01$ & -0.060 & 0.046 & $1.93 \mathrm{E}-01$ & -0.046 & 0.047 & 3.27E-01 \\
\hline rs1933270 & $\mathrm{T} / \mathrm{G}$ & 0.044 & 0.042 & 3.00E-01 & 0.020 & 0.042 & $6.34 \mathrm{E}-01$ & 0.038 & 0.033 & $2.49 E-01$ & $\underline{0.07} \underline{5}$ & 0.035 & 3.33E-02 \\
\hline rs7528604 & $G / A$ & 0.018 & 0.040 & 6.57E-01 & -0.005 & 0.041 & 9.01E-01 & 0.007 & 0.032 & 8.13E-01 & 0.014 & 0.042 & 7.39E-01 \\
\hline rs11210229 & $\mathrm{A} / \mathrm{G}$ & -0.041 & 0.042 & $3.19 E-01$ & -0.005 & 0.042 & $9.08 \mathrm{E}-01$ & -0.015 & 0.032 & $6.43 \mathrm{E}-01$ & -0.008 & 0.035 & 8.21E-01 \\
\hline
\end{tabular}




\begin{tabular}{|c|c|c|c|c|c|c|c|c|c|c|c|c|c|}
\hline \multirow[b]{2}{*}{ SNP } & \multirow[b]{2}{*}{ EA/BA } & \multicolumn{3}{|c|}{$\begin{array}{c}\text { Age } \leq 67 y \\
\text { (2,878 cases; } 2,944 \text { controls })\end{array}$} & \multicolumn{3}{|c|}{$\begin{array}{c}\text { Age }>67 y \\
\text { (3,208 cases; } 2,728 \text { controls) }\end{array}$} & \multicolumn{3}{|c|}{$\begin{array}{c}\text { PD duration } \leq 7 y \\
\text { (3,633 cases; } 6,836 \text { controls) }\end{array}$} & \multicolumn{3}{|c|}{$\begin{array}{c}\text { PD duration }>7 y \\
(3,271 \text { cases; } 6,836 \text { controls })\end{array}$} \\
\hline & & Beta & SE & P-value & Beta & SE & P-value & Beta & SE & P-value & Beta & SE & P-value \\
\hline rs7553348 & $\mathrm{G} / \mathrm{A}$ & 0.003 & 0.042 & $9.41 \mathrm{E}-01$ & -0.018 & 0.043 & $6.65 \mathrm{E}-01$ & 0.008 & 0.033 & 8.07E-01 & 0.008 & 0.035 & 8.29E-01 \\
\hline rs10922907 & $\mathrm{A} / \mathrm{T}$ & \multicolumn{12}{|c|}{ Excluded for MR } \\
\hline rs1931263 & $T / G$ & 0.010 & 0.041 & $8.15 \mathrm{E}-01$ & -0.048 & 0.041 & 2.47E-01 & -0.027 & 0.032 & 3.91E-01 & -0.041 & 0.034 & $2.28 \mathrm{E}-01$ \\
\hline rs7519626 & $\mathrm{C} / \mathrm{T}$ & 0.007 & 0.044 & 8.68E-01 & 0.001 & 0.044 & $9.84 \mathrm{E}-01$ & -0.015 & 0.044 & 7.30E-01 & 0.035 & 0.036 & 3.32E-01 \\
\hline rs9435340 & $\mathrm{T} / \mathrm{A}$ & & NA & & -0.010 & 0.044 & $8.16 \mathrm{E}-01$ & 0.002 & 0.034 & $9.44 \mathrm{E}-01$ & 0.019 & 0.036 & 5.96E-01 \\
\hline rs10918701 & $G / A$ & 0.004 & 0.042 & $9.15 \mathrm{E}-01$ & -0.077 & 0.042 & 6.64E-02 & 0.002 & 0.043 & 9.54E-01 & -0.018 & 0.035 & $6.11 \mathrm{E}-01$ \\
\hline rs2867112 & $\mathrm{T} / \mathrm{G}$ & -0.044 & 0.054 & 4.11E-01 & 0.095 & 0.074 & 1.99E-01 & -0.002 & 0.042 & 9.67E-01 & 0.028 & 0.045 & 5.42E-01 \\
\hline rs6741228 & $\mathrm{T} / \mathrm{C}$ & -0.021 & 0.057 & 7.13E-01 & 0.035 & 0.042 & 4.02E-01 & -0.025 & 0.032 & 4.38E-01 & 0.009 & 0.034 & 7.82E-01 \\
\hline rs62135536 & $\mathrm{C} / \mathrm{T}$ & \multicolumn{6}{|c|}{ Excluded for MR } & 0.034 & 0.112 & 7.60E-01 & -0.102 & 0.108 & $3.48 \mathrm{E}-01$ \\
\hline rs7569203 & $\mathrm{C} / \mathrm{A}$ & 0.025 & 0.044 & $5.65 \mathrm{E}-01$ & $\underline{0} .0 \underline{9} \underline{3}$ & 0.044 & 3.61E-02 & $\underline{0.07} \underline{3}$ & 0.034 & 3.18E-02 & 0.029 & 0.036 & 4.31E-01 \\
\hline rs13016665 & $\mathrm{A} / \mathrm{C}$ & 0.006 & 0.042 & 8.87E-01 & $\underline{0} . \overline{1} \underline{0} \overline{3}$ & 0.043 & 1.58E-02 & $\overline{0} . \overline{4} \overline{6}$ & 0.033 & 1.61E-01 & 0.042 & 0.035 & 2.34E-01 \\
\hline rs4671357 & $\mathrm{C} / \mathrm{T}$ & 0.002 & 0.042 & $9.70 \mathrm{E}-01$ & $0.00 \overline{1}$ & 0.041 & $9.74 \mathrm{E}-01$ & 0.018 & 0.032 & $5.84 \mathrm{E}-01$ & -0.030 & 0.036 & 3.99E-01 \\
\hline rs359243 & $\mathrm{C} / \mathrm{T}$ & -0.031 & 0.042 & 4.70E-01 & 0.050 & 0.043 & $2.49 \mathrm{E}-01$ & 0.047 & 0.042 & $2.65 \mathrm{E}-01$ & -0.031 & 0.047 & 5.06E-01 \\
\hline rs2678670 & $\mathrm{A} / \mathrm{T}$ & \multicolumn{12}{|c|}{ Excluded for MR } \\
\hline rs62155874 & $\mathrm{G} / \mathrm{A}$ & 0.003 & 0.062 & $9.66 \mathrm{E}-01$ & -0.069 & 0.063 & $2.71 \mathrm{E}-01$ & -0.032 & 0.049 & $5.15 \mathrm{E}-01$ & -0.006 & 0.052 & $9.08 \mathrm{E}-01$ \\
\hline rs3811038 & $\mathrm{C} / \mathrm{T}$ & -0.049 & 0.046 & 2.84E-01 & -0.008 & 0.061 & 8.91E-01 & 0.001 & 0.036 & $9.82 E-01$ & -0.011 & 0.038 & 7.74E-01 \\
\hline rs2890772 & $\mathrm{T} / \mathrm{G}$ & 0.006 & 0.041 & $8.91 \mathrm{E}-01$ & 0.040 & 0.042 & 3.38E-01 & 0.013 & 0.032 & 6.87E-01 & -0.004 & 0.034 & $9.00 \mathrm{E}-01$ \\
\hline rs62175972 & $\mathrm{T} / \mathrm{C}$ & 0.075 & 0.111 & 5.03E-01 & 0.016 & 0.111 & 8.82E-01 & 0.093 & 0.087 & $2.85 \mathrm{E}-01$ & -0.009 & 0.090 & 9.19E-01 \\
\hline rs3769949 & $\mathrm{A} / \mathrm{T}$ & \multicolumn{12}{|c|}{ Excluded for MR } \\
\hline rs13009008 & $\mathrm{A} / \mathrm{G}$ & 0.057 & 0.042 & 1.77E-01 & 0.046 & 0.043 & $2.84 \mathrm{E}-01$ & 0.008 & 0.033 & 8.02E-01 & $\underline{0.07} \underline{9}$ & 0.036 & 2.72E-02 \\
\hline rs4473348 & $\mathrm{T} / \mathrm{A}$ & 0.006 & 0.048 & $8.95 \mathrm{E}-01$ & -0.085 & 0.049 & 8.13E-02 & -0.071 & 0.037 & 5.79E-02 & -0.014 & 0.040 & 7.24E-01 \\
\hline rs12623702 & $\mathrm{G} / \mathrm{A}$ & -0.035 & 0.042 & 4.06E-01 & -0.012 & 0.043 & 7.74E-01 & -0.028 & 0.033 & 3.92E-01 & -0.054 & 0.035 & 1.26E-01 \\
\hline rs6779302 & $\mathrm{T} / \mathrm{G}$ & 0.032 & 0.042 & $4.51 \mathrm{E}-01$ & 0.049 & 0.043 & $2.55 \mathrm{E}-01$ & 0.047 & 0.033 & $1.59 \mathrm{E}-01$ & 0.011 & 0.035 & $7.45 \mathrm{E}-01$ \\
\hline rs6778080 & $\mathrm{T} / \mathrm{C}$ & -0.014 & 0.046 & 7.67E-01 & 0.005 & 0.047 & $9.20 \mathrm{E}-01$ & 0.005 & 0.042 & 8.97E-01 & -0.023 & 0.038 & 5.52E-01 \\
\hline rs775758 & $\mathrm{A} / \mathrm{T}$ & \multicolumn{12}{|c|}{ Excluded for MR } \\
\hline rs421983 & $\mathrm{T} / \mathrm{C}$ & -0.029 & 0.040 & 4.71E-01 & 0.020 & 0.041 & $6.25 \mathrm{E}-01$ & 0.007 & 0.031 & 8.30E-01 & -0.004 & 0.034 & $9.16 \mathrm{E}-01$ \\
\hline rs326341 & $\mathrm{G} / \mathrm{A}$ & -0.086 & 0.042 & 3.86E-02 & 0.025 & 0.042 & $5.50 \mathrm{E}-01$ & -0.028 & 0.032 & $3.89 E-01$ & -0.005 & 0.034 & $8.73 \mathrm{E}-01$ \\
\hline rs73220544 & $\mathrm{C} / \mathrm{A}$ & -0.086 & 0.060 & $1.50 \mathrm{E}-01$ & -0.050 & 0.085 & 5.54E-01 & -0.037 & 0.047 & 4.26E-01 & $\underline{-0.114}$ & 0.050 & 2.21E-02 \\
\hline rs9842947 & $\mathrm{T} / \mathrm{C}$ & 0.026 & 0.046 & 5.79E-01 & 0.020 & 0.046 & 6.69E-01 & 0.020 & 0.036 & 5.77E-01 & $\overline{0.045}$ & 0.038 & 2.39E-01 \\
\hline rs624833 & $\mathrm{T} / \mathrm{G}$ & -0.046 & 0.045 & 2.97E-01 & -0.088 & 0.063 & $1.62 \mathrm{E}-01$ & -0.113 & 0.034 & $1.02 E-03$ & -0.039 & 0.047 & 4.06E-01 \\
\hline rs61796681 & $\mathrm{T} / \mathrm{A}$ & 0.068 & 0.078 & $3.85 \mathrm{E}-01$ & 0.065 & 0.080 & 4.15E-01 & $\overline{0.074}$ & 0.061 & 2.27E-01 & -0.007 & 0.066 & $9.17 \mathrm{E}-01$ \\
\hline rs317021 & $\mathrm{A} / \mathrm{T}$ & 0.007 & 0.075 & $9.23 \mathrm{E}-01$ & 0.049 & 0.057 & $3.91 E-01$ & 0.093 & 0.044 & 3.50E-02 & 0.012 & 0.046 & $7.94 \mathrm{E}-01$ \\
\hline rs72678864 & $G / A$ & 0.050 & 0.057 & 3.86E-01 & 0.015 & 0.060 & 7.96E-01 & 0.065 & 0.046 & $1.54 \mathrm{E}-01$ & -0.008 & 0.048 & 8.68E-01 \\
\hline rs17576594 & $G / A$ & -0.059 & 0.046 & $2.01 \mathrm{E}-01$ & -0.009 & 0.047 & $8.42 E-01$ & -0.026 & 0.036 & 4.67E-01 & -0.063 & 0.038 & $9.77 \mathrm{E}-02$ \\
\hline rs11948770 & $\mathrm{C} / \mathrm{T}$ & -0.026 & 0.049 & $6.00 \mathrm{E}-01$ & -0.045 & 0.049 & $3.57 \mathrm{E}-01$ & -0.017 & 0.038 & $6.52 \mathrm{E}-01$ & -0.091 & 0.040 & 2.52E-02 \\
\hline rs71627581 & $G / A$ & \multicolumn{12}{|c|}{ Excluded for MR } \\
\hline rs10052591 & $\mathrm{T} / \mathrm{C}$ & 0.036 & 0.041 & 3.74E-01 & -0.008 & 0.041 & $8.45 \mathrm{E}-01$ & 0.005 & 0.032 & 8.73E-01 & 0.059 & 0.034 & $8.25 \mathrm{E}-02$ \\
\hline rs2080870 & $\mathrm{A} / \mathrm{T}$ & 0.067 & 0.047 & $1.50 \mathrm{E}-01$ & 0.080 & 0.048 & $9.20 \mathrm{E}-02$ & $\underline{0.08} \underline{6}$ & 0.037 & 1.91E-02 & 0.051 & 0.039 & $1.95 \mathrm{E}-01$ \\
\hline rs4571506 & $\mathrm{C} / \mathrm{T}$ & -0.072 & 0.052 & 1.67E-01 & 0.004 & 0.058 & $9.44 \mathrm{E}-01$ & -0.019 & 0.036 & $5.95 \mathrm{E}-01$ & $\underline{-0.076}$ & 0.034 & 2.58E-02 \\
\hline rs4957528 & $\mathrm{C} / \mathrm{A}$ & \multicolumn{12}{|c|}{ Excluded for MR } \\
\hline rs329120 & $\mathrm{C} / \mathrm{T}$ & -0.056 & 0.042 & $1.78 \mathrm{E}-01$ & -0.034 & 0.042 & $4.12 \mathrm{E}-01$ & -0.070 & 0.032 & 2.94E-02 & 0.009 & 0.034 & 7.96E-01 \\
\hline rs986391 & $\mathrm{G} / \mathrm{A}$ & -0.005 & 0.043 & 9.07E-01 & -0.022 & 0.044 & $6.22 \mathrm{E}-01$ & -0.019 & 0.034 & 5.67E-01 & -0.042 & 0.036 & 2.46E-01 \\
\hline rs13153393 & $\mathrm{G} / \mathrm{A}$ & 0.046 & 0.102 & $6.54 \mathrm{E}-01$ & 0.052 & 0.065 & $4.22 E-01$ & 0.002 & 0.071 & $9.75 \mathrm{E}-01$ & $\underline{0.13} \underline{4}$ & 0.054 & 1.30E-02 \\
\hline rs 245774 & $\mathrm{G} / \mathrm{A}$ & -0.060 & 0.046 & $1.88 \mathrm{E}-01$ & -0.054 & 0.046 & 2.40E-01 & -0.094 & 0.035 & 8.18E-03 & 0.004 & 0.039 & 9.08E-01 \\
\hline rs6935954 & $A / G$ & 0.021 & 0.042 & 6.24E-01 & 0.012 & 0.043 & 7.77E-01 & -0.019 & 0.043 & $6.52 \mathrm{E}-01$ & 0.084 & 0.035 & 1.57E-02 \\
\hline rs2254710 & $\mathrm{C} / \mathrm{A}$ & 0.028 & 0.073 & 7.05E-01 & 0.055 & 0.051 & 2.87E-01 & 0.022 & 0.039 & 5.78E-01 & 0.041 & 0.041 & $3.18 \mathrm{E}-01$ \\
\hline rs2894808 & $\mathrm{A} / \mathrm{T}$ & 0.034 & 0.067 & $6.09 E-01$ & -0.020 & 0.071 & 7.74E-01 & 0.004 & 0.054 & $9.36 \mathrm{E}-01$ & 0.043 & 0.057 & $4.55 \mathrm{E}-01$ \\
\hline rs12202536 & $G / A$ & -0.043 & 0.041 & 2.99E-01 & -0.106 & 0.042 & 1.11E-02 & -0.068 & 0.032 & $3.45 \mathrm{E}-02$ & -0.067 & 0.034 & 4.87E-02 \\
\hline
\end{tabular}




\begin{tabular}{|c|c|c|c|c|c|c|c|c|c|c|c|c|c|}
\hline \multirow[b]{2}{*}{ SNP } & \multirow[b]{2}{*}{ EA/BA } & \multicolumn{3}{|c|}{$\begin{array}{c}\text { Age } \leq 67 y \\
\text { (2,878 cases; } 2,944 \text { controls })\end{array}$} & \multicolumn{3}{|c|}{$\begin{array}{c}\text { Age }>67 y \\
\text { (3,208 cases; } 2,728 \text { controls) }\end{array}$} & \multicolumn{3}{|c|}{$\begin{array}{c}\text { PD duration } \leq 7 y \\
\text { (3,633 cases; } 6,836 \text { controls) }\end{array}$} & \multicolumn{3}{|c|}{$\begin{array}{c}\text { PD duration }>7 y \\
(3,271 \text { cases; } 6,836 \text { controls })\end{array}$} \\
\hline & & Beta & SE & P-value & Beta & SE & P-value & Beta & SE & P-value & Beta & SE & P-value \\
\hline rs7766610 & $\mathrm{C} / \mathrm{A}$ & -0.101 & 0.074 & $1.71 \mathrm{E}-01$ & -0.044 & 0.055 & 4.18E-01 & -0.090 & 0.042 & 3.33E-02 & -0.014 & 0.067 & 8.34E-01 \\
\hline rs1922018 & $\mathrm{C} / \mathrm{T}$ & 0.010 & 0.043 & 8.22E-01 & 0.001 & 0.044 & 9.77E-01 & $\overline{-0.004}$ & 0.033 & 8.98E-01 & 0.009 & 0.035 & 8.06E-01 \\
\hline rs10226228 & $\mathrm{G} / \mathrm{A}$ & -0.050 & 0.042 & 2.31E-01 & -0.035 & 0.044 & 4.32E-01 & -0.024 & 0.033 & 4.67E-01 & -0.033 & 0.036 & 3.61E-01 \\
\hline rs11768481 & $\mathrm{C} / \mathrm{A}$ & \multicolumn{12}{|c|}{ Excluded for MR } \\
\hline rs6962772 & $\mathrm{A} / \mathrm{G}$ & -0.059 & 0.057 & $2.95 \mathrm{E}-01$ & -0.019 & 0.057 & 7.36E-01 & -0.058 & 0.044 & $1.90 \mathrm{E}-01$ & -0.026 & 0.047 & $5.80 \mathrm{E}-01$ \\
\hline rs10282292 & $\mathrm{C} / \mathrm{T}$ & -0.026 & 0.043 & $5.40 \mathrm{E}-01$ & 0.027 & 0.050 & 5.95E-01 & 0.006 & 0.033 & 8.52E-01 & 0.005 & 0.038 & 8.99E-01 \\
\hline rs2401924 & $\mathrm{G} / \mathrm{C}$ & \multicolumn{12}{|c|}{ Excluded for MR } \\
\hline rs7807019 & $\mathrm{G} / \mathrm{A}$ & 0.013 & 0.041 & 7.56E-01 & 0.004 & 0.042 & $9.21 \mathrm{E}-01$ & -0.006 & 0.032 & 8.59E-01 & 0.044 & 0.034 & $1.98 \mathrm{E}-01$ \\
\hline rs6957896 & $\mathrm{T} / \mathrm{C}$ & -0.027 & 0.052 & 6.07E-01 & -0.039 & 0.052 & 4.57E-01 & -0.040 & 0.047 & 3.97E-01 & -0.022 & 0.040 & 5.86E-01 \\
\hline rs4731925 & $\mathrm{T} / \mathrm{C}$ & -0.014 & 0.044 & 7.50E-01 & -0.042 & 0.044 & $3.42 \mathrm{E}-01$ & 0.026 & 0.045 & $5.54 \mathrm{E}-01$ & $\underline{-0.084}$ & 0.036 & 2.07E-02 \\
\hline rs35169606 & $\mathrm{T} / \mathrm{G}$ & \multicolumn{12}{|c|}{ Excluded for MR } \\
\hline rs11783093 & $\mathrm{C} / \mathrm{T}$ & -0.004 & 0.080 & $9.61 \mathrm{E}-01$ & 0.011 & 0.055 & 8.47E-01 & 0.010 & 0.043 & 8.19E-01 & -0.048 & 0.057 & 4.02E-01 \\
\hline rs2062882 & $\mathrm{A} / \mathrm{G}$ & 0.007 & 0.042 & $8.71 \mathrm{E}-01$ & -0.024 & 0.041 & $5.56 \mathrm{E}-01$ & -0.007 & 0.035 & $8.41 \mathrm{E}-01$ & -0.054 & 0.044 & $2.21 \mathrm{E}-01$ \\
\hline rs72674867 & $\mathrm{A} / \mathrm{T}$ & 0.033 & 0.045 & 4.70E-01 & 0.042 & 0.047 & $3.75 \mathrm{E}-01$ & 0.028 & 0.036 & $4.42 \mathrm{E}-01$ & -0.017 & 0.048 & 7.16E-01 \\
\hline rs4543592 & $\mathrm{C} / \mathrm{T}$ & -0.036 & 0.041 & 3.84E-01 & -0.071 & 0.042 & $9.30 \mathrm{E}-02$ & -0.023 & 0.033 & 4.74E-01 & -0.036 & 0.034 & $2.91 \mathrm{E}-01$ \\
\hline rs7039819 & $G / A$ & -0.009 & 0.043 & 8.27E-01 & 0.002 & 0.043 & $9.58 \mathrm{E}-01$ & 0.010 & 0.033 & 7.74E-01 & -0.001 & 0.036 & $9.69 \mathrm{E}-01$ \\
\hline rs1246265 & $\mathrm{C} / \mathrm{T}$ & 0.061 & 0.045 & $1.76 \mathrm{E}-01$ & -0.006 & 0.045 & 8.95E-01 & 0.011 & 0.035 & $7.42 \mathrm{E}-01$ & -0.005 & 0.037 & 8.98E-01 \\
\hline rs 1221148 & $\mathrm{C} / \mathrm{G}$ & 0.056 & 0.043 & 1.89E-01 & 0.030 & 0.055 & 5.93E-01 & 0.050 & 0.034 & $1.34 \mathrm{E}-01$ & -0.031 & 0.035 & $3.86 \mathrm{E}-01$ \\
\hline rs13296519 & $\mathrm{T} / \mathrm{G}$ & -0.016 & 0.059 & 7.89E-01 & -0.044 & 0.043 & $3.01 E-01$ & -0.020 & 0.033 & 5.53E-01 & -0.010 & 0.035 & 7.76E-01 \\
\hline rs113382419 & $A / C$ & 0.037 & 0.068 & 5.87E-01 & -0.045 & 0.070 & $5.21 \mathrm{E}-01$ & 0.036 & 0.054 & 5.01E-01 & -0.073 & 0.060 & 2.24E-01 \\
\hline rs11255908 & $\mathrm{G} / \mathrm{T}$ & 0.008 & 0.045 & 8.66E-01 & -0.036 & 0.048 & $4.45 \mathrm{E}-01$ & -0.014 & 0.036 & $6.93 \mathrm{E}-01$ & 0.027 & 0.039 & $4.92 \mathrm{E}-01$ \\
\hline rs2675638 & $\mathrm{G} / \mathrm{A}$ & 0.014 & 0.064 & 8.32E-01 & 0.014 & 0.042 & 7.48E-01 & -0.040 & 0.033 & 2.19E-01 & -0.010 & 0.037 & 7.88E-01 \\
\hline rs10823968 & $\mathrm{A} / \mathrm{T}$ & 0.002 & 0.044 & $9.55 \mathrm{E}-01$ & 0.029 & 0.044 & 4.98E-01 & 0.028 & 0.034 & $4.09 E-01$ & -0.010 & 0.036 & 7.76E-01 \\
\hline rs61857951 & $\mathrm{C} / \mathrm{A}$ & \multicolumn{12}{|c|}{ Excluded for MR } \\
\hline rs7077678 & $\mathrm{C} / \mathrm{T}$ & -0.010 & 0.041 & 8.09E-01 & -0.020 & 0.043 & 6.42E-01 & -0.013 & 0.033 & $6.97 \mathrm{E}-01$ & 0.007 & 0.035 & $8.40 \mathrm{E}-01$ \\
\hline rs12244388 & $A / G$ & -0.098 & 0.042 & 2.00E-02 & -0.048 & 0.042 & $2.57 \mathrm{E}-01$ & -0.086 & 0.033 & 8.52E-03 & -0.036 & 0.035 & $2.95 \mathrm{E}-01$ \\
\hline rs3896224 & $\mathrm{A} / \mathrm{G}$ & 0.028 & 0.042 & $5.08 \mathrm{E}-01$ & -0.019 & 0.042 & 6.57E-01 & -0.006 & 0.032 & 8.55E-01 & 0.004 & 0.034 & $9.12 \mathrm{E}-01$ \\
\hline rs34866095 & $\mathrm{G} / \mathrm{A}$ & $\underline{-0.101}$ & 0.044 & 2.38E-02 & -0.051 & 0.045 & $2.49 \mathrm{E}-01$ & -0.020 & 0.034 & $5.70 \mathrm{E}-01$ & $\underline{-0.085}$ & 0.037 & 2.27E-02 \\
\hline rs75742406 & $\mathrm{G} / \mathrm{A}$ & -0.050 & 0.049 & $3.10 \mathrm{E}-01$ & -0.063 & 0.051 & $2.19 E-01$ & -0.033 & 0.039 & $4.01 \mathrm{E}-01$ & $\overline{-0.052}$ & 0.050 & 2.97E-01 \\
\hline rs17309874 & $\mathrm{A} / \mathrm{G}$ & -0.059 & 0.051 & $2.45 \mathrm{E}-01$ & -0.032 & 0.051 & $5.30 \mathrm{E}-01$ & -0.054 & 0.039 & 1.67E-01 & 0.003 & 0.041 & $9.48 \mathrm{E}-01$ \\
\hline rs4391802 & $\mathrm{A} / \mathrm{G}$ & 0.003 & 0.045 & $9.41 \mathrm{E}-01$ & $\underline{0.11} \underline{3}$ & 0.046 & 1.34E-02 & 0.051 & 0.035 & $1.51 \mathrm{E}-01$ & 0.050 & 0.038 & 1.85E-01 \\
\hline rs112282219 & $\mathrm{A} / \mathrm{G}$ & -0.061 & 0.108 & 5.69E-01 & \multicolumn{3}{|c|}{ Excluded for MR } & 0.022 & 0.087 & 7.97E-01 & 0.051 & 0.091 & $5.75 \mathrm{E}-01$ \\
\hline rs9919670 & $\mathrm{A} / \mathrm{G}$ & -0.019 & 0.042 & $6.49 E-01$ & -0.028 & 0.042 & 5.09E-01 & -0.019 & 0.033 & $5.69 \mathrm{E}-01$ & -0.013 & 0.035 & 7.17E-01 \\
\hline rs74086911 & $\mathrm{G} / \mathrm{A}$ & -0.201 & 0.079 & 1.13E-02 & 0.116 & 0.083 & $1.60 \mathrm{E}-01$ & 0.006 & 0.063 & $9.21 \mathrm{E}-01$ & -0.134 & 0.065 & 3.97E-02 \\
\hline rs7297175 & $\mathrm{C} / \mathrm{T}$ & $\overline{0.042}$ & 0.043 & 3.25E-01 & -0.044 & 0.044 & 3.16E-01 & 0.011 & 0.034 & 7.40E-01 & $\overline{0.029}$ & 0.036 & $4.21 \mathrm{E}-01$ \\
\hline rs10879871 & $\mathrm{G} / \mathrm{T}$ & 0.045 & 0.043 & $2.95 \mathrm{E}-01$ & -0.046 & 0.044 & $2.99 E-01$ & -0.003 & 0.034 & $9.34 \mathrm{E}-01$ & -0.005 & 0.036 & 8.85E-01 \\
\hline rs 12831617 & $\mathrm{~T} / \mathrm{C}$ & -0.033 & 0.045 & 4.66E-01 & 0.047 & 0.047 & $3.18 \mathrm{E}-01$ & 0.029 & 0.036 & 4.27E-01 & 0.021 & 0.039 & 5.84E-01 \\
\hline rs6562474 & $\mathrm{C} / \mathrm{G}$ & 0.001 & 0.043 & $9.72 \mathrm{E}-01$ & 0.041 & 0.043 & $3.45 \mathrm{E}-01$ & 0.024 & 0.033 & 4.64E-01 & -0.010 & 0.035 & 7.73E-01 \\
\hline rs7333559 & $G / A$ & -0.064 & 0.053 & $2.26 \mathrm{E}-01$ & -0.027 & 0.052 & 6.06E-01 & -0.079 & 0.041 & $5.14 \mathrm{E}-02$ & 0.009 & 0.055 & $8.73 \mathrm{E}-01$ \\
\hline rs860326 & $\mathrm{C} / \mathrm{T}$ & 0.049 & 0.063 & 4.35E-01 & -0.023 & 0.043 & 5.97E-01 & 0.011 & 0.033 & 7.32E-01 & -0.030 & 0.035 & $3.95 \mathrm{E}-01$ \\
\hline rs7155595 & $\mathrm{C} / \mathrm{A}$ & 0.009 & 0.045 & $8.44 \mathrm{E}-01$ & 0.021 & 0.045 & 6.35E-01 & -0.008 & 0.035 & $8.11 \mathrm{E}-01$ & 0.004 & 0.048 & $9.26 \mathrm{E}-01$ \\
\hline rs3742365 & $\mathrm{C} / \mathrm{T}$ & -0.012 & 0.043 & 7.80E-01 & 0.015 & 0.043 & 7.33E-01 & 0.001 & 0.033 & $9.72 \mathrm{E}-01$ & 0.013 & 0.035 & 7.09E-01 \\
\hline rs35175834 & $\mathrm{A} / \mathrm{G}$ & -0.027 & 0.049 & $5.78 E-01$ & -0.062 & 0.050 & 2.13E-01 & -0.036 & 0.038 & $3.55 \mathrm{E}-01$ & -0.037 & 0.041 & $3.68 \mathrm{E}-01$ \\
\hline rs28485305 & $\mathrm{C} / \mathrm{T}$ & 0.036 & 0.042 & $3.86 \mathrm{E}-01$ & 0.001 & 0.042 & $9.87 \mathrm{E}-01$ & 0.058 & 0.033 & $7.68 \mathrm{E}-02$ & -0.040 & 0.035 & $2.41 \mathrm{E}-01$ \\
\hline rs8042849 & $\mathrm{C} / \mathrm{T}$ & -0.035 & 0.043 & $4.26 \mathrm{E}-01$ & 0.053 & 0.043 & $2.23 \mathrm{E}-01$ & 0.032 & 0.034 & 3.33E-01 & -0.041 & 0.036 & 2.60E-01 \\
\hline rs8042134 & $\mathrm{G} / \mathrm{T}$ & 0.009 & 0.056 & $8.79 E-01$ & 0.067 & 0.042 & $1.11 \mathrm{E}-01$ & 0.041 & 0.033 & 2.07E-01 & 0.026 & 0.035 & 4.49E-01 \\
\hline rs6598539 & $\mathrm{C} / \mathrm{T}$ & $<0.001$ & 0.042 & $9.98 \mathrm{E}-01$ & -0.017 & 0.042 & $6.94 \mathrm{E}-01$ & -0.021 & 0.033 & $5.27 \mathrm{E}-01$ & -0.013 & 0.047 & 7.88E-01 \\
\hline rs11861214 & $\mathrm{G} / \mathrm{T}$ & 0.011 & 0.051 & 8.31E-01 & 0.050 & 0.052 & 3.35E-01 & 0.047 & 0.040 & 2.42E-01 & 0.044 & 0.042 & $2.91 \mathrm{E}-01$ \\
\hline
\end{tabular}




\begin{tabular}{|c|c|c|c|c|c|c|c|c|c|c|c|c|c|}
\hline \multirow[b]{2}{*}{ SNP } & \multirow[b]{2}{*}{ EA/BA } & \multicolumn{3}{|c|}{$\begin{array}{c}\text { Age } \leq 67 y \\
\text { (2,878 cases; } 2,944 \text { controls) }\end{array}$} & \multicolumn{3}{|c|}{$\begin{array}{c}\text { Age }>67 y \\
\text { (3,208 cases; } 2,728 \text { controls })\end{array}$} & \multicolumn{3}{|c|}{$\begin{array}{c}\text { PD duration } \leq 7 y \\
\text { (3,633 cases; } 6,836 \text { controls) }\end{array}$} & \multicolumn{3}{|c|}{$\begin{array}{c}\text { PD duration }>7 y \\
(3,271 \text { cases; } 6,836 \text { controls })\end{array}$} \\
\hline & & Beta & SE & P-value & Beta & SE & P-value & Beta & SE & P-value & Beta & SE & P-value \\
\hline rs12708665 & $\mathrm{G} / \mathrm{A}$ & $<0.001$ & 0.044 & 9.99E-01 & -0.065 & 0.045 & $1.51 \mathrm{E}-01$ & -0.038 & 0.035 & $2.68 \mathrm{E}-01$ & 0.009 & 0.037 & 8.18E-01 \\
\hline rs57611503 & $\mathrm{G} / \mathrm{A}$ & \multirow{2}{*}{\multicolumn{6}{|c|}{$\begin{array}{l}\text { Excluded for MR } \\
\text { Excluded for MR }\end{array}$}} & $\underline{-0.111}$ & 0.036 & 2.14E-03 & -0.080 & 0.049 & 9.86E-02 \\
\hline rs889398 & $\mathrm{C} / \mathrm{T}$ & & & & & & & $\overline{0.019}$ & 0.061 & 7.52E-01 & 0.019 & 0.060 & 7.47E-01 \\
\hline rs60952428 & $\mathrm{T} / \mathrm{C}$ & \multicolumn{12}{|c|}{ Excluded for MR } \\
\hline rs1050847 & $\mathrm{C} / \mathrm{T}$ & 0.006 & 0.042 & 8.81E-01 & -0.014 & 0.043 & 7.39E-01 & 0.019 & 0.033 & $5.69 \mathrm{E}-01$ & -0.074 & 0.035 & 3.51E-02 \\
\hline rs369230 & $\mathrm{T} / \mathrm{G}$ & -0.019 & 0.048 & $6.94 \mathrm{E}-01$ & -0.057 & 0.049 & 2.47E-01 & -0.036 & 0.038 & 3.44E-01 & $\overline{-0.044}$ & 0.050 & 3.75E-01 \\
\hline rs8614 & $\mathrm{A} / \mathrm{C}$ & $\underline{0.141}$ & 0.059 & $1.65 \mathrm{E}-02$ & 0.011 & 0.061 & 8.52E-01 & $\underline{0.098}$ & 0.046 & 3.27E-02 & 0.064 & 0.048 & $1.86 \mathrm{E}-01$ \\
\hline rs732083 & $\mathrm{G} / \mathrm{A}$ & $-\overline{0.041}$ & 0.044 & 3.57E-01 & -0.015 & 0.045 & $7.45 \mathrm{E}-01$ & -0.035 & 0.035 & 3.06E-01 & -0.031 & 0.037 & 4.04E-01 \\
\hline rs9904288 & $\mathrm{T} / \mathrm{C}$ & -0.016 & 0.045 & 7.19E-01 & -0.038 & 0.046 & 4.13E-01 & -0.037 & 0.035 & 2.92E-01 & -0.007 & 0.038 & 8.61E-01 \\
\hline rs67596067 & $\mathrm{A} / \mathrm{G}$ & -0.026 & 0.043 & $5.42 \mathrm{E}-01$ & 0.047 & 0.044 & 2.86E-01 & 0.008 & 0.034 & $8.12 E-01$ & 0.035 & 0.036 & 3.31E-01 \\
\hline rs12967855 & $A / G$ & $\underline{-0.102}$ & 0.044 & 2.06E-02 & 0.010 & 0.045 & 8.31E-01 & -0.052 & 0.035 & $1.33 \mathrm{E}-01$ & 0.002 & 0.037 & 9.47E-01 \\
\hline rs62098013 & $A / G$ & $\overline{0.067}$ & 0.044 & $1.22 \mathrm{E}-01$ & 0.025 & 0.044 & $5.78 \mathrm{E}-01$ & 0.102 & 0.034 & 2.81E-03 & -0.014 & 0.050 & 7.77E-01 \\
\hline rs71367545 & $A / G$ & -0.063 & 0.054 & $2.41 \mathrm{E}-01$ & 0.077 & 0.055 & $1.63 \mathrm{E}-01$ & -0.014 & 0.043 & 7.40E-01 & 0.062 & 0.044 & $1.64 \mathrm{E}-01$ \\
\hline rs76608582 & $\mathrm{C} / \mathrm{A}$ & \multicolumn{12}{|c|}{ NA in COURAGE-PD } \\
\hline rs35343344 & $\mathrm{C} / \mathrm{A}$ & 0.030 & 0.069 & $6.64 \mathrm{E}-01$ & 0.068 & 0.050 & $1.76 \mathrm{E}-01$ & 0.037 & 0.039 & $3.46 \mathrm{E}-01$ & 0.040 & 0.041 & 3.31E-01 \\
\hline rs4814873 & $\mathrm{C} / \mathrm{T}$ & -0.008 & 0.048 & $8.62 \mathrm{E}-01$ & -0.043 & 0.049 & 3.80E-01 & 0.013 & 0.038 & 7.35E-01 & -0.079 & 0.040 & 4.76E-02 \\
\hline rs6119897 & $\mathrm{A} / \mathrm{G}$ & 0.034 & 0.053 & $5.18 \mathrm{E}-01$ & -0.061 & 0.053 & $2.42 \mathrm{E}-01$ & -0.032 & 0.041 & $4.40 \mathrm{E}-01$ & $\overline{0.003}$ & 0.042 & 9.52E-01 \\
\hline rs12481282 & $\mathrm{C} / \mathrm{G}$ & -0.010 & 0.048 & 8.38E-01 & -0.080 & 0.048 & 9.98E-02 & -0.041 & 0.038 & $2.71 \mathrm{E}-01$ & -0.013 & 0.040 & 7.43E-01 \\
\hline rs348809 & $\mathrm{G} / \mathrm{A}$ & -0.024 & 0.043 & 5.77E-01 & -0.005 & 0.043 & 9.07E-01 & -0.037 & 0.044 & $4.06 \mathrm{E}-01$ & 0.009 & 0.035 & 8.03E-01 \\
\hline rs6011779 & $\mathrm{C} / \mathrm{T}$ & -0.107 & 0.072 & $1.38 \mathrm{E}-01$ & 0.042 & 0.051 & 4.17E-01 & -0.056 & 0.040 & $1.63 \mathrm{E}-01$ & 0.036 & 0.042 & 3.96E-01 \\
\hline rs147412694 & $A / G$ & -0.072 & 0.060 & 2.31E-01 & 0.053 & 0.060 & $3.76 \mathrm{E}-01$ & -0.024 & 0.047 & $6.03 \mathrm{E}-01$ & -0.032 & 0.050 & $5.20 \mathrm{E}-01$ \\
\hline rs2838834 & $\mathrm{T} / \mathrm{C}$ & 0.037 & 0.044 & 3.97E-01 & -0.013 & 0.059 & 8.27E-01 & 0.003 & 0.035 & $9.26 \mathrm{E}-01$ & 0.038 & 0.050 & 4.41E-01 \\
\hline rs136233 & $\mathrm{G} / \mathrm{A}$ & 0.034 & 0.051 & 5.04E-01 & $\underline{-0.114}$ & 0.052 & 2.98E-02 & -0.035 & 0.040 & 3.85E-01 & -0.025 & 0.042 & 5.52E-01 \\
\hline rs202645 & $\mathrm{G} / \mathrm{A}$ & $\underline{0.172}$ & 0.051 & 7.11E-04 & $\overline{0.100}$ & 0.067 & 1.37E-01 & $\underline{0.121}$ & 0.039 & 2.13E-03 & $\underline{0.138}$ & 0.055 & 1.17E-02 \\
\hline \multicolumn{14}{|c|}{ Smoking initiation (per 1-SD increase in the of prevalence of ever smoking) } \\
\hline rs12130857 & $G / A$ & -0.028 & 0.043 & 5.16E-01 & -0.009 & 0.045 & 8.38E-01 & -0.038 & 0.034 & $2.70 \mathrm{E}-01$ & 0.003 & 0.037 & $9.43 \mathrm{E}-01$ \\
\hline rs3820277 & $\mathrm{G} / \mathrm{T}$ & -0.036 & 0.041 & 3.79E-01 & -0.041 & 0.057 & 4.74E-01 & -0.042 & 0.048 & 3.83E-01 & -0.035 & 0.034 & 3.02E-01 \\
\hline rs1889571 & $\mathrm{G} / \mathrm{T}$ & -0.002 & 0.065 & $9.81 \mathrm{E}-01$ & 0.009 & 0.065 & 8.91E-01 & 0.030 & 0.050 & $5.48 \mathrm{E}-01$ & 0.011 & 0.053 & 8.27E-01 \\
\hline rs10914684 & $\mathrm{G} / \mathrm{A}$ & 0.010 & 0.043 & 8.11E-01 & -0.023 & 0.044 & 5.93E-01 & -0.039 & 0.034 & $2.45 \mathrm{E}-01$ & 0.006 & 0.036 & 8.72E-01 \\
\hline rs951740 & $\mathrm{A} / \mathrm{G}$ & -0.109 & 0.059 & 6.57E-02 & 0.033 & 0.043 & 4.44E-01 & -0.039 & 0.033 & $2.43 \mathrm{E}-01$ & -0.055 & 0.046 & 2.28E-01 \\
\hline rs12022778 & $\mathrm{C} / \mathrm{A}$ & 0.068 & 0.052 & 1.93E-01 & -0.012 & 0.054 & 8.26E-01 & 0.042 & 0.041 & $3.11 \mathrm{E}-01$ & 0.078 & 0.061 & 2.05E-01 \\
\hline rs4912332 & $\mathrm{T} / \mathrm{C}$ & 0.074 & 0.057 & $1.95 \mathrm{E}-01$ & 0.036 & 0.042 & $3.91 \mathrm{E}-01$ & $\underline{0.084}$ & 0.032 & 8.77E-03 & -0.031 & 0.034 & 3.67E-01 \\
\hline rs80054503 & $\mathrm{T} / \mathrm{C}$ & \multicolumn{12}{|c|}{ NA in COURAGE-P $\overline{\mathrm{P}}--$} \\
\hline rs10789369 & $\mathrm{A} / \mathrm{G}$ & -0.046 & 0.042 & 2.72E-01 & -0.047 & 0.043 & 2.74E-01 & -0.034 & 0.033 & 2.93E-01 & -0.018 & 0.035 & 5.99E-01 \\
\hline rs1514176 & $G / A$ & -0.001 & 0.042 & 9.82E-01 & 0.023 & 0.055 & $6.72 \mathrm{E}-01$ & 0.005 & 0.033 & 8.82E-01 & 0.014 & 0.035 & $6.99 \mathrm{E}-01$ \\
\hline rs11162019 & $\mathrm{C} / \mathrm{T}$ & -0.010 & 0.043 & 8.17E-01 & -0.031 & 0.044 & 4.86E-01 & -0.016 & 0.034 & $6.38 \mathrm{E}-01$ & -0.034 & 0.036 & $3.45 \mathrm{E}-01$ \\
\hline rs1008078 & $\mathrm{T} / \mathrm{C}$ & -0.052 & 0.041 & 2.07E-01 & 0.047 & 0.042 & 2.61E-01 & -0.038 & 0.041 & $3.54 \mathrm{E}-01$ & 0.008 & 0.055 & 8.86E-01 \\
\hline rs12027999 & $\mathrm{T} / \mathrm{C}$ & -0.007 & 0.067 & $9.15 E-01$ & 0.096 & 0.086 & 2.67E-01 & 0.028 & 0.052 & $5.98 \mathrm{E}-01$ & -0.009 & 0.056 & 8.70E-01 \\
\hline rs 45444697 & $\mathrm{G} / \mathrm{C}$ & -0.013 & 0.053 & 8.02E-01 & -0.011 & 0.075 & $8.78 \mathrm{E}-01$ & -0.016 & 0.042 & $6.98 \mathrm{E}-01$ & 0.005 & 0.043 & 9.04E-01 \\
\hline rs2901785 & $\mathrm{G} / \mathrm{A}$ & 0.041 & 0.054 & 4.44E-01 & 0.004 & 0.053 & $9.37 E-01$ & 0.052 & 0.045 & 2.47E-01 & -0.015 & 0.034 & 6.67E-01 \\
\hline rs147052174 & $\mathrm{T} / \mathrm{G}$ & \multicolumn{12}{|c|}{ Excluded for MR } \\
\hline rs35656245 & $A / G$ & 0.006 & 0.044 & 8.97E-01 & -0.019 & 0.045 & $6.79 \mathrm{E}-01$ & -0.006 & 0.046 & 8.90E-01 & -0.007 & 0.037 & 8.44E-01 \\
\hline rs12739243 & $\mathrm{T} / \mathrm{C}$ & 0.003 & 0.048 & $9.44 \mathrm{E}-01$ & -0.017 & 0.050 & $7.41 \mathrm{E}-01$ & 0.035 & 0.038 & 3.65E-01 & 0.013 & 0.040 & 7.50E-01 \\
\hline rs876793 & $\mathrm{T} / \mathrm{C}$ & 0.034 & 0.045 & 4.43E-01 & 0.084 & 0.045 & 6.08E-02 & 0.005 & 0.051 & 9.27E-01 & 0.074 & 0.037 & 4.37E-02 \\
\hline rs6731872 & $\mathrm{G} / \mathrm{T}$ & -0.026 & 0.051 & $6.20 \mathrm{E}-01$ & 0.058 & 0.053 & $2.71 \mathrm{E}-01$ & 0.005 & 0.040 & $9.04 \mathrm{E}-01$ & $\overline{0.02 \overline{9}}$ & 0.044 & 5.08E-01 \\
\hline rs1022376 & $\mathrm{T} / \mathrm{C}$ & 0.020 & 0.041 & $6.25 E-01$ & 0.015 & 0.042 & 7.27E-01 & -0.005 & 0.032 & 8.74E-01 & 0.023 & 0.035 & $5.12 \mathrm{E}-01$ \\
\hline rs61533748 & $\mathrm{C} / \mathrm{T}$ & -0.011 & 0.057 & 8.50E-01 & 0.042 & 0.043 & 3.29E-01 & -0.020 & 0.034 & 5.53E-01 & 0.021 & 0.036 & 5.53E-01 \\
\hline
\end{tabular}




\begin{tabular}{|c|c|c|c|c|c|c|c|c|c|c|c|c|c|}
\hline \multirow[b]{2}{*}{ SNP } & \multirow[b]{2}{*}{ EA/BA } & \multicolumn{3}{|c|}{$\begin{array}{c}\text { Age } \leq 67 y \\
\text { (2,878 cases; } 2,944 \text { controls })\end{array}$} & \multicolumn{3}{|c|}{$\begin{array}{c}\text { Age }>67 y \\
\text { (3,208 cases; } 2,728 \text { controls) }\end{array}$} & \multicolumn{3}{|c|}{$\begin{array}{c}\text { PD duration } \leq 7 y \\
\text { (3,633 cases; } 6,836 \text { controls) }\end{array}$} & \multicolumn{3}{|c|}{$\begin{array}{c}\text { PD duration }>7 y \\
(3,271 \text { cases; } 6,836 \text { controls })\end{array}$} \\
\hline & & Beta & SE & P-value & Beta & SE & P-value & Beta & SE & P-value & Beta & SE & P-value \\
\hline rs2710634 & $\mathrm{T} / \mathrm{C}$ & -0.035 & 0.041 & 4.02E-01 & -0.031 & 0.042 & 4.52E-01 & -0.027 & 0.032 & $4.00 \mathrm{E}-01$ & -0.054 & 0.034 & $1.12 \mathrm{E}-01$ \\
\hline rs7598402 & $C / G$ & \multicolumn{12}{|c|}{ Excluded for MR } \\
\hline rs10490159 & $\mathrm{T} / \mathrm{C}$ & -0.009 & 0.041 & $8.29 \mathrm{E}-01$ & -0.124 & 0.055 & 2.37E-02 & -0.006 & 0.032 & 8.42E-01 & -0.061 & 0.034 & 7.61E-02 \\
\hline rs359247 & $\mathrm{T} / \mathrm{A}$ & -0.009 & 0.042 & 8.32E-01 & $\overline{0.022}$ & 0.043 & $6.13 \mathrm{E}-01$ & 0.020 & 0.033 & 5.49E-01 & -0.025 & 0.035 & 4.88E-01 \\
\hline rs12714017 & $\mathrm{C} / \mathrm{T}$ & 0.042 & 0.041 & $3.10 \mathrm{E}-01$ & -0.018 & 0.042 & $6.76 \mathrm{E}-01$ & -0.019 & 0.032 & 5.63E-01 & 0.059 & 0.034 & 8.36E-02 \\
\hline rs13392222 & $\mathrm{A} / \mathrm{C}$ & 0.067 & 0.065 & 3.01E-01 & 0.005 & 0.088 & 9.54E-01 & 0.022 & 0.050 & 6.57E-01 & -0.032 & 0.052 & 5.34E-01 \\
\hline rs1901477 & $\mathrm{G} / \mathrm{A}$ & -0.031 & 0.041 & 4.48E-01 & 0.047 & 0.041 & 2.57E-01 & $<0.001$ & 0.043 & 9.94E-01 & 0.034 & 0.050 & 5.03E-01 \\
\hline rs3811038 & $\mathrm{C} / \mathrm{T}$ & -0.049 & 0.046 & 2.84E-01 & -0.008 & 0.061 & 8.91E-01 & 0.001 & 0.036 & $9.82 \mathrm{E}-01$ & -0.011 & 0.038 & 7.74E-01 \\
\hline rs34399632 & $G / A$ & 0.050 & 0.059 & $3.98 \mathrm{E}-01$ & -0.026 & 0.084 & $7.58 \mathrm{E}-01$ & 0.001 & 0.059 & $9.81 \mathrm{E}-01$ & -0.052 & 0.046 & $2.50 \mathrm{E}-01$ \\
\hline rs6756212 & $\mathrm{C} / \mathrm{T}$ & -0.022 & 0.041 & 5.97E-01 & 0.027 & 0.041 & $5.15 \mathrm{E}-01$ & -0.015 & 0.032 & 6.33E-01 & -0.015 & 0.034 & $6.52 \mathrm{E}-01$ \\
\hline rs16826827 & $\mathrm{T} / \mathrm{C}$ & -0.003 & 0.065 & $9.68 \mathrm{E}-01$ & -0.086 & 0.064 & 1.79E-01 & -0.054 & 0.049 & 2.77E-01 & -0.017 & 0.052 & 7.41E-01 \\
\hline rs1445649 & $\mathrm{C} / \mathrm{T}$ & 0.005 & 0.041 & $9.11 \mathrm{E}-01$ & -0.059 & 0.041 & $1.51 \mathrm{E}-01$ & -0.014 & 0.032 & $6.50 \mathrm{E}-01$ & -0.033 & 0.034 & $3.25 E-01$ \\
\hline rs12474587 & $T / G$ & 0.081 & 0.042 & 5.53E-02 & 0.019 & 0.043 & $6.63 \mathrm{E}-01$ & 0.062 & 0.033 & $6.28 \mathrm{E}-02$ & 0.021 & 0.035 & 5.59E-01 \\
\hline rs13007361 & $A / G$ & 0.047 & 0.072 & $5.12 \mathrm{E}-01$ & 0.007 & 0.049 & 8.93E-01 & $\underline{0.08} \underline{2}$ & 0.038 & 2.98E-02 & -0.053 & 0.042 & 2.05E-01 \\
\hline rs6750529 & $\mathrm{T} / \mathrm{C}$ & 0.004 & 0.047 & $9.30 \mathrm{E}-01$ & -0.066 & 0.048 & $1.66 \mathrm{E}-01$ & -0.054 & 0.037 & 1.43E-01 & -0.006 & 0.039 & 8.79E-01 \\
\hline rs17229285 & $\mathrm{C} / \mathrm{T}$ & 0.058 & 0.065 & 3.73E-01 & -0.038 & 0.042 & 3.62E-01 & -0.016 & 0.032 & 6.17E-01 & 0.040 & 0.035 & 2.49E-01 \\
\hline rs62193862 & $A / G$ & \multicolumn{12}{|c|}{ Excluded for MR } \\
\hline rs4674993 & $A / G$ & 0.015 & 0.052 & 7.70E-01 & 0.034 & 0.075 & 6.51E-01 & 0.044 & 0.057 & 4.37E-01 & -0.048 & 0.053 & 3.67E-01 \\
\hline rs11713899 & $\mathrm{C} / \mathrm{A}$ & -0.049 & 0.053 & $3.55 E-01$ & -0.006 & 0.055 & $9.18 \mathrm{E}-01$ & -0.082 & 0.042 & $5.29 E-02$ & 0.016 & 0.045 & $7.20 \mathrm{E}-01$ \\
\hline rs748832 & $\mathrm{G} / \mathrm{A}$ & 0.045 & 0.043 & $2.91 \mathrm{E}-01$ & 0.054 & 0.044 & $2.15 E-01$ & 0.062 & 0.034 & $6.52 \mathrm{E}-02$ & 0.020 & 0.035 & 5.64E-01 \\
\hline rs2526390 & $\mathrm{T} / \mathrm{C}$ & -0.061 & 0.062 & $3.29 \mathrm{E}-01$ & 0.049 & 0.044 & $2.62 \mathrm{E}-01$ & -0.001 & 0.034 & $9.69 \mathrm{E}-01$ & -0.006 & 0.036 & $8.58 \mathrm{E}-01$ \\
\hline rs221988 & $\mathrm{A} / \mathrm{C}$ & 0.047 & 0.066 & 4.75E-01 & -0.017 & 0.044 & 7.02E-01 & 0.049 & 0.034 & $1.52 E-01$ & -0.009 & 0.036 & 8.02E-01 \\
\hline rs11128203 & $\mathrm{A} / \mathrm{T}$ & \multicolumn{12}{|c|}{ Excluded for MR } \\
\hline rs62246017 & $\mathrm{G} / \mathrm{A}$ & -0.028 & 0.045 & 5.31E-01 & -0.046 & 0.046 & $3.14 \mathrm{E}-01$ & -0.038 & 0.036 & 2.84E-01 & -0.050 & 0.048 & 2.92E-01 \\
\hline rs12633090 & $\mathrm{G} / \mathrm{C}$ & 0.087 & 0.052 & $9.46 \mathrm{E}-02$ & 0.014 & 0.052 & 7.87E-01 & 0.072 & 0.057 & $2.06 \mathrm{E}-01$ & 0.021 & 0.059 & 7.17E-01 \\
\hline rs1549979 & $\mathrm{C} / \mathrm{T}$ & 0.037 & 0.042 & $3.75 \mathrm{E}-01$ & 0.017 & 0.042 & $6.91 \mathrm{E}-01$ & -0.009 & 0.033 & 7.83E-01 & 0.050 & 0.035 & $1.51 \mathrm{E}-01$ \\
\hline rs6437769 & $\mathrm{T} / \mathrm{C}$ & -0.028 & 0.057 & $6.21 \mathrm{E}-01$ & 0.086 & 0.058 & $1.40 \mathrm{E}-01$ & 0.032 & 0.033 & $3.31 E-01$ & 0.013 & 0.034 & $7.11 \mathrm{E}-01$ \\
\hline rs9288999 & $A / G$ & 0.018 & 0.046 & $6.98 \mathrm{E}-01$ & -0.137 & 0.048 & 4.24E-03 & -0.044 & 0.036 & 2.31E-01 & -0.067 & 0.038 & 7.91E-02 \\
\hline rs6438436 & $\mathrm{T} / \mathrm{C}$ & 0.028 & 0.084 & $7.40 \mathrm{E}-01$ & $\overline{0.075}$ & 0.057 & $1.86 \mathrm{E}-01$ & 0.016 & 0.043 & 7.09E-01 & 0.071 & 0.046 & 1.24E-01 \\
\hline rs9826984 & $\mathrm{G} / \mathrm{A}$ & 0.017 & 0.042 & 6.89E-01 & 0.029 & 0.042 & 4.82E-01 & -0.019 & 0.032 & $5.65 E-01$ & $\underline{0.06} \underline{9}$ & 0.034 & 4.42E-02 \\
\hline rs2279829 & $\mathrm{C} / \mathrm{T}$ & 0.057 & 0.053 & $2.82 E-01$ & 0.027 & 0.053 & 6.13E-01 & 0.026 & 0.041 & 5.31E-01 & -0.004 & 0.043 & $9.28 \mathrm{E}-01$ \\
\hline rs2319545 & $\mathrm{A} / \mathrm{C}$ & -0.025 & 0.063 & 6.86E-01 & -0.020 & 0.062 & 7.46E-01 & -0.019 & 0.066 & $7.70 \mathrm{E}-01$ & 0.032 & 0.050 & 5.31E-01 \\
\hline rs 1714521 & $A / C$ & -0.034 & 0.042 & 4.12E-01 & -0.036 & 0.043 & 4.06E-01 & 0.002 & 0.033 & $9.41 \mathrm{E}-01$ & -0.036 & 0.044 & 4.10E-01 \\
\hline rs 1449012 & $\mathrm{C} / \mathrm{T}$ & 0.034 & 0.054 & 5.29E-01 & -0.048 & 0.042 & $2.57 \mathrm{E}-01$ & -0.024 & 0.044 & $5.79 E-01$ & 0.066 & 0.034 & 5.49E-02 \\
\hline rs 1187820 & $\mathrm{C} / \mathrm{T}$ & 0.031 & 0.044 & 4.84E-01 & 0.069 & 0.061 & $2.61 \mathrm{E}-01$ & 0.002 & 0.035 & $9.57 \mathrm{E}-01$ & 0.037 & 0.053 & $4.82 \mathrm{E}-01$ \\
\hline rs7631379 & $\mathrm{C} / \mathrm{T}$ & 0.010 & 0.076 & 8.92E-01 & -0.133 & 0.074 & $7.15 \mathrm{E}-02$ & 0.006 & 0.043 & 8.86E-01 & -0.093 & 0.046 & 4.13E-02 \\
\hline rs4140932 & $\mathrm{T} / \mathrm{A}$ & \multicolumn{12}{|c|}{ Excluded for MR } \\
\hline rs59537158 & $\mathrm{T} / \mathrm{C}$ & $\underline{-0.109}$ & 0.053 & 4.12E-02 & 0.070 & 0.054 & 1.96E-01 & -0.049 & 0.042 & 2.43E-01 & 0.048 & 0.043 & 2.69E-01 \\
\hline rs58400863 & $\mathrm{G} / \mathrm{A}$ & $\overline{0.018}$ & 0.043 & $6.85 E-01$ & 0.048 & 0.044 & 2.68E-01 & -0.003 & 0.034 & $9.39 E-01$ & 0.029 & 0.036 & $4.24 \mathrm{E}-01$ \\
\hline rs112725451 & $\mathrm{T} / \mathrm{C}$ & -0.016 & 0.052 & $7.54 \mathrm{E}-01$ & 0.055 & 0.054 & 3.04E-01 & -0.013 & 0.041 & $7.51 \mathrm{E}-01$ & 0.030 & 0.044 & 4.97E-01 \\
\hline rs1160685 & $\mathrm{G} / \mathrm{C}$ & \multicolumn{12}{|c|}{ Excluded for MR } \\
\hline rs3934797 & $\mathrm{G} / \mathrm{A}$ & 0.020 & 0.055 & 7.12E-01 & 0.010 & 0.058 & $8.60 \mathrm{E}-01$ & 0.041 & 0.044 & 3.54E-01 & 0.003 & 0.068 & $9.60 \mathrm{E}-01$ \\
\hline rs71602617 & $\mathrm{C} / \mathrm{T}$ & -0.016 & 0.052 & 7.64E-01 & 0.047 & 0.064 & $4.60 \mathrm{E}-01$ & -0.035 & 0.040 & $3.84 \mathrm{E}-01$ & 0.033 & 0.042 & $4.42 \mathrm{E}-01$ \\
\hline rs7696257 & $A / G$ & 0.020 & 0.043 & $6.40 \mathrm{E}-01$ & -0.035 & 0.044 & 4.17E-01 & 0.024 & 0.034 & 4.68E-01 & -0.041 & 0.036 & 2.53E-01 \\
\hline rs1116690 & $\mathrm{G} / \mathrm{A}$ & -0.061 & 0.048 & 2.03E-01 & -0.046 & 0.050 & $3.58 \mathrm{E}-01$ & -0.049 & 0.038 & $1.95 \mathrm{E}-01$ & 0.001 & 0.040 & $9.78 \mathrm{E}-01$ \\
\hline rs13110073 & $\mathrm{T} / \mathrm{C}$ & -0.010 & 0.042 & $8.02 E-01$ & -0.074 & 0.042 & $7.85 \mathrm{E}-02$ & -0.054 & 0.032 & $9.92 \mathrm{E}-02$ & -0.052 & 0.035 & 1.38E-01 \\
\hline rs62340589 & $\mathrm{C} / \mathrm{G}$ & -0.067 & 0.054 & $2.14 \mathrm{E}-01$ & 0.048 & 0.053 & $3.65 \mathrm{E}-01$ & 0.014 & 0.042 & $7.40 \mathrm{E}-01$ & -0.011 & 0.044 & 8.02E-01 \\
\hline rs12517438 & $\mathrm{G} / \mathrm{T}$ & 0.040 & 0.041 & 3.23E-01 & -0.003 & 0.042 & $9.36 \mathrm{E}-01$ & 0.026 & 0.032 & 4.05E-01 & -0.009 & 0.034 & 7.92E-01 \\
\hline
\end{tabular}




\begin{tabular}{|c|c|c|c|c|c|c|c|c|c|c|c|c|c|}
\hline \multirow[b]{2}{*}{ SNP } & \multirow[b]{2}{*}{ EA/BA } & \multicolumn{3}{|c|}{$\begin{array}{c}\text { Age } \leq 67 y \\
\text { (2,878 cases; } 2,944 \text { controls })\end{array}$} & \multicolumn{3}{|c|}{$\begin{array}{c}\text { Age }>67 y \\
\text { (3,208 cases; } 2,728 \text { controls })\end{array}$} & \multicolumn{3}{|c|}{$\begin{array}{c}\text { PD duration } \leq 7 y \\
\text { (3,633 cases; } 6,836 \text { controls })\end{array}$} & \multicolumn{3}{|c|}{$\begin{array}{c}\text { PD duration }>7 y \\
(3,271 \text { cases } ; 6,836 \text { controls })\end{array}$} \\
\hline & & Beta & SE & P-value & Beta & SE & P-value & Beta & SE & P-value & Beta & SE & P-value \\
\hline rs35375873 & $\mathrm{G} / \mathrm{C}$ & \multicolumn{12}{|c|}{ Excluded for MR } \\
\hline rs71592686 & $\mathrm{C} / \mathrm{T}$ & 0.048 & 0.046 & 2.94E-01 & 0.053 & 0.046 & $2.50 \mathrm{E}-01$ & $\underline{0.08} \underline{\underline{5}}$ & 0.036 & 1.71E-02 & 0.023 & 0.038 & 5.57E-01 \\
\hline rs6874731 & $\mathrm{G} / \mathrm{T}$ & 0.017 & 0.041 & $6.81 \mathrm{E}-01$ & -0.020 & 0.041 & $6.28 \mathrm{E}-01$ & 0.008 & 0.032 & 7.94E-01 & -0.022 & 0.034 & $5.22 \mathrm{E}-01$ \\
\hline rs6452785 & $\mathrm{C} / \mathrm{T}$ & -0.066 & 0.041 & $1.05 \mathrm{E}-01$ & 0.013 & 0.058 & $8.20 \mathrm{E}-01$ & -0.012 & 0.032 & 7.16E-01 & -0.065 & 0.034 & 5.53E-02 \\
\hline rs 42417 & $\mathrm{~T} / \mathrm{C}$ & -0.070 & 0.046 & $1.32 \mathrm{E}-01$ & -0.129 & 0.072 & $7.50 \mathrm{E}-02$ & $\underline{-0.116}$ & 0.052 & 2.51E-02 & -0.055 & 0.038 & $1.52 \mathrm{E}-01$ \\
\hline rs72780746 & $\mathrm{T} / \mathrm{C}$ & -0.134 & 0.051 & 9.26E-03 & 0.002 & 0.052 & $9.64 \mathrm{E}-01$ & -0.063 & 0.040 & $1.15 \mathrm{E}-01$ & -0.049 & 0.043 & 2.53E-01 \\
\hline rs329124 & $A / G$ & $\overline{-0.040}$ & 0.041 & $3.31 \mathrm{E}-01$ & -0.045 & 0.042 & $2.78 \mathrm{E}-01$ & -0.061 & 0.032 & 5.71E-02 & 0.004 & 0.034 & 9.07E-01 \\
\hline rs 1385108 & $\mathrm{~T} / \mathrm{C}$ & -0.011 & 0.049 & $8.25 \mathrm{E}-01$ & 0.033 & 0.050 & $5.11 \mathrm{E}-01$ & -0.005 & 0.038 & 8.96E-01 & -0.016 & 0.040 & 6.92E-01 \\
\hline rs6890961 & $\mathrm{C} / \mathrm{T}$ & -0.109 & 0.066 & $1.00 \mathrm{E}-01$ & 0.007 & 0.044 & $8.74 \mathrm{E}-01$ & -0.018 & 0.034 & 5.91E-01 & -0.064 & 0.036 & 7.78E-02 \\
\hline rs 4044321 & $\mathrm{~A} / \mathrm{G}$ & -0.003 & 0.043 & $9.46 \mathrm{E}-01$ & -0.016 & 0.044 & $7.20 \mathrm{E}-01$ & -0.010 & 0.034 & 7.62E-01 & -0.045 & 0.036 & $2.18 \mathrm{E}-01$ \\
\hline rs2173019 & $\mathrm{A} / \mathrm{T}$ & 0.050 & 0.080 & $5.29 \mathrm{E}-01$ & 0.021 & 0.055 & 7.03E-01 & 0.018 & 0.043 & $6.71 \mathrm{E}-01$ & 0.091 & 0.045 & 4.15E-02 \\
\hline rs1150668 & $\mathrm{T} / \mathrm{G}$ & -0.027 & 0.042 & $5.20 \mathrm{E}-01$ & 0.034 & 0.044 & 4.34E-01 & 0.021 & 0.033 & 5.31E-01 & -0.006 & 0.035 & 8.69E-01 \\
\hline rs3218116 & $\mathrm{C} / \mathrm{T}$ & -0.045 & 0.079 & $5.65 \mathrm{E}-01$ & 0.013 & 0.049 & 7.85E-01 & 0.001 & 0.038 & $9.78 \mathrm{E}-01$ & -0.026 & 0.040 & 5.14E-01 \\
\hline rs 160631 & $\mathrm{~T} / \mathrm{G}$ & 0.063 & 0.046 & $1.71 \mathrm{E}-01$ & 0.040 & 0.047 & 3.88E-01 & $\underline{0.071}$ & 0.036 & 4.84E-02 & 0.011 & 0.038 & $7.71 \mathrm{E}-01$ \\
\hline rs7743165 & $\mathrm{G} / \mathrm{T}$ & $<0.001$ & 0.062 & $9.94 \mathrm{E}-01$ & $\underline{-0.104}$ & 0.042 & 1.26E-02 & -0.065 & 0.032 & 4.49E-02 & -0.059 & 0.044 & $1.85 \mathrm{E}-01$ \\
\hline rs10945141 & $A / G$ & -0.002 & 0.046 & $9.72 \mathrm{E}-01$ & $\overline{0.017}$ & 0.047 & $7.21 \mathrm{E}-01$ & -0.011 & 0.036 & 7.59E-01 & 0.040 & 0.038 & $2.90 \mathrm{E}-01$ \\
\hline rs17554906 & $C / G$ & \multicolumn{12}{|c|}{ Excluded for MR } \\
\hline rs6568832 & $A / G$ & -0.096 & 0.048 & 4.55E-02 & 0.006 & 0.049 & $9.01 \mathrm{E}-01$ & -0.022 & 0.038 & 5.57E-01 & -0.026 & 0.040 & $5.11 \mathrm{E}-01$ \\
\hline rs12195240 & $\mathrm{A} / \mathrm{G}$ & $\overline{0.009}$ & 0.045 & 8.37E-01 & -0.096 & 0.044 & 3.03E-02 & -0.031 & 0.034 & $3.68 \mathrm{E}-01$ & -0.023 & 0.037 & $5.24 \mathrm{E}-01$ \\
\hline rs6936160 & $\mathrm{T} / \mathrm{C}$ & 0.080 & 0.045 & $7.41 \mathrm{E}-02$ & $\overline{-0.001}$ & 0.045 & $9.80 \mathrm{E}-01$ & 0.053 & 0.035 & $1.26 \mathrm{E}-01$ & -0.025 & 0.037 & 4.99E-01 \\
\hline rs118202 & $\mathrm{G} / \mathrm{T}$ & -0.098 & 0.075 & $1.91 \mathrm{E}-01$ & -0.045 & 0.055 & 4.08E-01 & -0.093 & 0.042 & 2.82E-02 & -0.016 & 0.067 & 8.08E-01 \\
\hline rs 1737329 & $\mathrm{G} / \mathrm{C}$ & -0.041 & 0.047 & 3.84E-01 & 0.011 & 0.067 & 8.70E-01 & -0.024 & 0.037 & $5.14 \mathrm{E}-01$ & -0.001 & 0.053 & $9.85 \mathrm{E}-01$ \\
\hline rs6948707 & $\mathrm{G} / \mathrm{T}$ & -0.003 & 0.041 & $9.51 \mathrm{E}-01$ & -0.032 & 0.057 & 5.73E-01 & 0.002 & 0.032 & $9.45 \mathrm{E}-01$ & 0.007 & 0.035 & 8.48E-01 \\
\hline rs7809303 & $\mathrm{G} / \mathrm{A}$ & -0.104 & 0.043 & 1.68E-02 & -0.020 & 0.044 & 6.52E-01 & -0.068 & 0.034 & 4.63E-02 & -0.063 & 0.036 & $8.17 \mathrm{E}-02$ \\
\hline rs 1030015 & $\mathrm{~T} / \mathrm{G}$ & -0.028 & 0.049 & $5.61 \mathrm{E}-01$ & 0.014 & 0.051 & 7.81E-01 & 0.026 & 0.048 & $5.80 \mathrm{E}-01$ & -0.011 & 0.034 & 7.56E-01 \\
\hline rs4727189 & $\mathrm{C} / \mathrm{T}$ & $0.08 \underline{3}$ & 0.042 & 4.58E-02 & -0.005 & 0.043 & $9.08 \mathrm{E}-01$ & -0.004 & 0.033 & 8.94E-01 & 0.068 & 0.035 & 5.47E-02 \\
\hline rs11768481 & $\mathrm{C} / \mathrm{A}$ & \multicolumn{12}{|c|}{ Excluded for MR } \\
\hline rs13437771 & $\mathrm{A} / \mathrm{G}$ & -0.060 & 0.057 & 2.93E-01 & -0.018 & 0.057 & 7.46E-01 & -0.058 & 0.044 & $1.88 \mathrm{E}-01$ & -0.025 & 0.047 & 5.92E-01 \\
\hline rs 10233018 & $G / A$ & 0.011 & 0.041 & $7.88 \mathrm{E}-01$ & 0.008 & 0.042 & $8.42 \mathrm{E}-01$ & -0.017 & 0.032 & 5.93E-01 & 0.054 & 0.034 & $1.13 \mathrm{E}-01$ \\
\hline rs10953957 & $A / G$ & 0.071 & 0.055 & $1.99 \mathrm{E}-01$ & -0.017 & 0.043 & $6.83 \mathrm{E}-01$ & 0.023 & 0.033 & 4.76E-01 & 0.048 & 0.035 & $1.75 \mathrm{E}-01$ \\
\hline rs77283305 & $G / A$ & -0.018 & 0.044 & 6.84E-01 & -0.047 & 0.044 & 2.92E-01 & 0.015 & 0.035 & $6.60 \mathrm{E}-01$ & $\underline{-0.085}$ & 0.036 & 1.86E-02 \\
\hline rs 10279261 & $G / A$ & -0.011 & 0.062 & 8.58E-01 & -0.019 & 0.044 & 6.62E-01 & 0.011 & 0.034 & 7.33E-01 & -0.037 & 0.036 & $3.10 \mathrm{E}-01$ \\
\hline rs 4326350 & $\mathrm{C} / \mathrm{G}$ & \multicolumn{12}{|c|}{ Excluded for MR } \\
\hline rs11783093 & $\mathrm{C} / \mathrm{T}$ & -0.004 & 0.080 & $9.61 \mathrm{E}-01$ & 0.011 & 0.055 & 8.47E-01 & 0.010 & 0.043 & 8.19E-01 & -0.048 & 0.057 & 4.02E-01 \\
\hline rs7836565 & $\mathrm{C} / \mathrm{T}$ & 0.038 & 0.046 & 4.09E-01 & 0.114 & 0.046 & 1.37E-02 & 0.047 & 0.036 & $1.90 \mathrm{E}-01$ & 0.083 & 0.038 & 2.82E-02 \\
\hline rs13261666 & $\mathrm{G} / \mathrm{T}$ & -0.052 & 0.055 & $3.41 \mathrm{E}-01$ & -0.020 & 0.041 & $6.28 \mathrm{E}-01$ & -0.014 & 0.032 & $6.54 \mathrm{E}-01$ & -0.020 & 0.034 & 5.59E-01 \\
\hline rs3850736 & $\mathrm{G} / \mathrm{C}$ & \multicolumn{12}{|c|}{ Excluded for MR } \\
\hline rs2063976 & $\mathrm{C} / \mathrm{T}$ & 0.021 & 0.043 & 6.34E-01 & -0.059 & 0.044 & $1.79 \mathrm{E}-01$ & 0.001 & 0.034 & $9.71 \mathrm{E}-01$ & -0.030 & 0.036 & 4.14E-01 \\
\hline rs6986430 & $\mathrm{T} / \mathrm{C}$ & -0.034 & 0.048 & 4.73E-01 & 0.068 & 0.049 & $1.63 \mathrm{E}-01$ & -0.010 & 0.037 & 7.85E-01 & 0.053 & 0.040 & $1.86 \mathrm{E}-01$ \\
\hline rs290601 & $\mathrm{T} / \mathrm{C}$ & 0.040 & 0.046 & $3.85 \mathrm{E}-01$ & 0.032 & 0.047 & 4.89E-01 & 0.039 & 0.035 & $2.76 \mathrm{E}-01$ & -0.027 & 0.038 & $4.80 \mathrm{E}-01$ \\
\hline rs3847244 & $\mathrm{T} / \mathrm{C}$ & -0.046 & 0.042 & $2.72 \mathrm{E}-01$ & -0.058 & 0.043 & 1.78E-01 & -0.028 & 0.033 & 3.99E-01 & -0.036 & 0.035 & $3.10 \mathrm{E}-01$ \\
\hline rs11791671 & $\mathrm{T} / \mathrm{C}$ & -0.027 & 0.130 & 8.34E-01 & -0.016 & 0.088 & 8.57E-01 & -0.012 & 0.096 & $9.00 \mathrm{E}-01$ & 0.078 & 0.088 & $3.78 \mathrm{E}-01$ \\
\hline rs7024924 & $\mathrm{C} / \mathrm{T}$ & -0.061 & 0.054 & 2.61E-01 & -0.014 & 0.055 & 7.92E-01 & -0.010 & 0.042 & $8.15 \mathrm{E}-01$ & -0.002 & 0.045 & $9.71 \mathrm{E}-01$ \\
\hline rs10966092 & $\mathrm{T} / \mathrm{C}$ & -0.009 & 0.047 & 8.53E-01 & -0.046 & 0.046 & $3.24 \mathrm{E}-01$ & -0.048 & 0.046 & $2.95 \mathrm{E}-01$ & 0.018 & 0.039 & $6.42 \mathrm{E}-01$ \\
\hline rs4877285 & $\mathrm{G} / \mathrm{A}$ & -0.069 & 0.074 & $3.53 \mathrm{E}-01$ & -0.046 & 0.060 & 4.47E-01 & -0.036 & 0.034 & 2.92E-01 & -0.088 & 0.037 & $1.58 \mathrm{E}-02$ \\
\hline rs2378662 & $A / G$ & 0.019 & 0.043 & $6.51 \mathrm{E}-01$ & -0.019 & 0.067 & 7.81E-01 & -0.017 & 0.044 & 6.96E-01 & $\overline{0.011}$ & 0.035 & 7.57E-01 \\
\hline rs4837631 & $\mathrm{C} / \mathrm{T}$ & 0.049 & 0.042 & $2.44 \mathrm{E}-01$ & 0.028 & 0.043 & $5.08 \mathrm{E}-01$ & 0.045 & 0.033 & $1.72 \mathrm{E}-01$ & -0.028 & 0.035 & 4.29E-01 \\
\hline rs34553878 & $G / A$ & \multicolumn{12}{|c|}{ Excluded for MR } \\
\hline
\end{tabular}




\begin{tabular}{|c|c|c|c|c|c|c|c|c|c|c|c|c|c|}
\hline \multirow[b]{2}{*}{ SNP } & \multirow[b]{2}{*}{ EA/BA } & \multicolumn{3}{|c|}{$\begin{array}{c}\text { Age } \leq 67 y \\
\text { (2,878 cases; } 2,944 \text { controls) }\end{array}$} & \multicolumn{3}{|c|}{$\begin{array}{c}\text { Age }>67 y \\
(3,208 \text { cases; } 2,728 \text { controls })\end{array}$} & \multicolumn{3}{|c|}{$\begin{array}{c}\text { PD duration } \leq 7 y \\
(3,633 \text { cases; } 6,836 \text { controls })\end{array}$} & \multicolumn{3}{|c|}{$\begin{array}{c}\text { PD duration }>7 y \\
(3,271 \text { cases; } 6,836 \text { controls })\end{array}$} \\
\hline & & Beta & SE & P-value & Beta & SE & P-value & Beta & SE & P-value & Beta & SE & P-value \\
\hline rs10858334 & $\mathrm{G} / \mathrm{C}$ & -0.076 & 0.060 & $2.11 \mathrm{E}-01$ & -0.124 & 0.079 & $1.14 \mathrm{E}-01$ & -0.068 & 0.048 & $1.55 \mathrm{E}-01$ & -0.076 & 0.069 & $2.72 \mathrm{E}-01$ \\
\hline rs7920501 & $\mathrm{T} / \mathrm{A}$ & \multicolumn{12}{|c|}{ Excluded for MR } \\
\hline rs1291821 & $G / A$ & -0.012 & 0.041 & 7.65E-01 & 0.004 & 0.042 & $9.20 \mathrm{E}-01$ & -0.024 & 0.032 & 4.64E-01 & -0.009 & 0.034 & 7.95E-01 \\
\hline rs7072776 & $A / G$ & 0.020 & 0.047 & 6.77E-01 & -0.019 & 0.048 & $6.98 \mathrm{E}-01$ & -0.014 & 0.037 & 6.99E-01 & 0.040 & 0.040 & 3.10E-01 \\
\hline rs2796793 & $A / G$ & $\underline{0.100}$ & 0.043 & 2.11E-02 & 0.011 & 0.043 & $7.88 \mathrm{E}-01$ & $\underline{0.081}$ & 0.033 & 1.55E-02 & 0.038 & 0.053 & 4.73E-01 \\
\hline rs1733760 & $\mathrm{C} / \mathrm{T}$ & -0.005 & 0.042 & 8.98E-01 & 0.008 & 0.043 & 8.57E-01 & -0.014 & 0.033 & 6.73E-01 & 0.052 & 0.035 & 1.38E-01 \\
\hline rs7921378 & $\mathrm{G} / \mathrm{C}$ & \multicolumn{12}{|c|}{ Excluded for MR } \\
\hline rs11594623 & $\mathrm{C} / \mathrm{T}$ & -0.043 & 0.050 & 3.89E-01 & $\underline{-0.133}$ & 0.051 & 9.75E-03 & -0.076 & 0.039 & $5.41 \mathrm{E}-02$ & -0.032 & 0.042 & 4.36E-01 \\
\hline rs12244388 & $A / G$ & -0.098 & 0.042 & 2.00E-02 & -0.048 & 0.042 & $2.57 \mathrm{E}-01$ & -0.086 & 0.033 & 8.52E-03 & -0.036 & 0.035 & 2.95E-01 \\
\hline rs10885480 & $\mathrm{T} / \mathrm{C}$ & $\overline{-0.072}$ & 0.047 & $1.28 \mathrm{E}-01$ & 0.046 & 0.047 & $3.35 \mathrm{E}-01$ & $\overline{0.003}$ & 0.037 & $9.34 \mathrm{E}-01$ & -0.044 & 0.039 & $2.54 \mathrm{E}-01$ \\
\hline rs4752018 & $\mathrm{A} / \mathrm{C}$ & -0.040 & 0.048 & $4.02 \mathrm{E}-01$ & 0.017 & 0.049 & 7.27E-01 & -0.049 & 0.050 & 3.33E-01 & -0.030 & 0.040 & 4.63E-01 \\
\hline rs9423279 & $\mathrm{C} / \mathrm{G}$ & \multicolumn{12}{|c|}{ Excluded for MR } \\
\hline rs6265 & $\mathrm{C} / \mathrm{T}$ & 0.060 & 0.052 & 2.46E-01 & -0.012 & 0.052 & 8.17E-01 & 0.039 & 0.040 & 3.30E-01 & 0.023 & 0.043 & 5.88E-01 \\
\hline rs2939756 & $\mathrm{G} / \mathrm{A}$ & -0.019 & 0.041 & $6.33 \mathrm{E}-01$ & -0.010 & 0.042 & 8.17E-01 & -0.019 & 0.032 & 5.52E-01 & -0.017 & 0.034 & $6.28 \mathrm{E}-01$ \\
\hline rs1381775 & $\mathrm{T} / \mathrm{C}$ & -0.006 & 0.046 & $9.02 E-01$ & -0.071 & 0.047 & $1.26 \mathrm{E}-01$ & -0.034 & 0.036 & $3.45 E-01$ & -0.060 & 0.038 & 1.14E-01 \\
\hline rs61886926 & $\mathrm{C} / \mathrm{T}$ & -0.056 & 0.042 & $1.82 \mathrm{E}-01$ & -0.003 & 0.064 & 9.63E-01 & -0.020 & 0.033 & 5.38E-01 & -0.001 & 0.044 & 9.78E-01 \\
\hline rs 644740 & $\mathrm{C} / \mathrm{T}$ & -0.015 & 0.041 & $7.21 \mathrm{E}-01$ & -0.008 & 0.041 & 8.48E-01 & -0.015 & 0.032 & $6.42 \mathrm{E}-01$ & -0.003 & 0.034 & 9.33E-01 \\
\hline rs7943721 & $\mathrm{G} / \mathrm{A}$ & \multicolumn{12}{|c|}{ NA in COURAGE-PD } \\
\hline rs7929518 & $\mathrm{G} / \mathrm{A}$ & $<0.001$ & 0.048 & $9.99 \mathrm{E}-01$ & -0.027 & 0.048 & $5.75 \mathrm{E}-01$ & -0.042 & 0.037 & $2.55 \mathrm{E}-01$ & -0.014 & 0.040 & 7.20E-01 \\
\hline rs2155646 & $\mathrm{C} / \mathrm{T}$ & -0.018 & 0.042 & $6.63 \mathrm{E}-01$ & -0.027 & 0.042 & $5.27 \mathrm{E}-01$ & -0.018 & 0.033 & $5.81 \mathrm{E}-01$ & -0.012 & 0.035 & 7.24E-01 \\
\hline rs1713676 & $A / G$ & 0.019 & 0.042 & $6.49 \mathrm{E}-01$ & 0.060 & 0.045 & $1.86 \mathrm{E}-01$ & 0.048 & 0.032 & $1.31 \mathrm{E}-01$ & 0.039 & 0.034 & 2.56E-01 \\
\hline rs540860 & $\mathrm{G} / \mathrm{A}$ & 0.061 & 0.040 & $1.34 \mathrm{E}-01$ & 0.030 & 0.042 & 4.67E-01 & 0.034 & 0.032 & 2.82E-01 & 0.055 & 0.034 & 1.04E-01 \\
\hline rs1106363 & $\mathrm{T} / \mathrm{C}$ & -0.013 & 0.042 & $7.62 \mathrm{E}-01$ & 0.057 & 0.043 & $1.83 \mathrm{E}-01$ & -0.026 & 0.033 & 4.26E-01 & 0.067 & 0.035 & 5.57E-02 \\
\hline rs2010921 & $A / G$ & 0.017 & 0.045 & $6.98 \mathrm{E}-01$ & 0.034 & 0.045 & $4.48 \mathrm{E}-01$ & 0.037 & 0.035 & $2.88 \mathrm{E}-01$ & 0.037 & 0.037 & 3.29E-01 \\
\hline rs11057005 & $A / G$ & -0.045 & 0.061 & 4.57E-01 & -0.082 & 0.043 & $6.05 \mathrm{E}-02$ & -0.033 & 0.048 & 4.92E-01 & -0.021 & 0.036 & $5.62 \mathrm{E}-01$ \\
\hline rs13906 & $\mathrm{C} / \mathrm{T}$ & $\underline{-0.139}$ & 0.066 & 3.55E-02 & 0.122 & 0.068 & 7.26E-02 & 0.058 & 0.052 & $2.72 E-01$ & -0.057 & 0.054 & 2.95E-01 \\
\hline rs4759229 & $\mathrm{G} / \mathrm{A}$ & 0.008 & 0.060 & 8.94E-01 & -0.005 & 0.046 & $9.20 \mathrm{E}-01$ & $<0.001$ & 0.036 & $9.94 \mathrm{E}-01$ & 0.008 & 0.037 & $8.29 E-01$ \\
\hline rs7969559 & $\mathrm{A} / \mathrm{G}$ & -0.018 & 0.044 & $6.75 \mathrm{E}-01$ & -0.038 & 0.045 & $3.88 \mathrm{E}-01$ & -0.065 & 0.035 & 6.19E-02 & 0.041 & 0.037 & $2.70 \mathrm{E}-01$ \\
\hline rs7134009 & $\mathrm{T} / \mathrm{C}$ & \multirow{2}{*}{\multicolumn{6}{|c|}{ Excluded for MR }} & -0.030 & 0.034 & 3.79E-01 & $<0.001$ & 0.037 & 9.92E-01 \\
\hline rs77215829 & $A / C$ & & & & & & & 0.041 & 0.084 & $6.22 \mathrm{E}-01$ & -0.030 & 0.066 & $6.45 \mathrm{E}-01$ \\
\hline rs1109480 & $\mathrm{G} / \mathrm{A}$ & -0.021 & 0.043 & $6.22 \mathrm{E}-01$ & -0.041 & 0.043 & 3.33E-01 & -0.043 & 0.033 & $1.99 E-01$ & -0.026 & 0.035 & 4.61E-01 \\
\hline rs11611651 & $A / G$ & -0.054 & 0.077 & $4.82 \mathrm{E}-01$ & \multicolumn{3}{|c|}{ Excluded for MR } & -0.005 & 0.060 & $9.28 \mathrm{E}-01$ & 0.032 & 0.063 & $6.13 E-01$ \\
\hline rs17197663 & $\mathrm{G} / \mathrm{A}$ & 0.092 & 0.059 & 1.17E-01 & 0.023 & 0.060 & 7.06E-01 & 0.018 & 0.072 & 8.04E-01 & -0.021 & 0.051 & 6.83E-01 \\
\hline rs4264267 & $\mathrm{T} / \mathrm{C}$ & -0.046 & 0.042 & $2.72 \mathrm{E}-01$ & -0.008 & 0.043 & $8.58 \mathrm{E}-01$ & -0.031 & 0.033 & $3.44 \mathrm{E}-01$ & -0.017 & 0.035 & 6.16E-01 \\
\hline rs61959481 & $\mathrm{G} / \mathrm{A}$ & 0.046 & 0.050 & $3.60 \mathrm{E}-01$ & -0.049 & 0.052 & $3.40 \mathrm{E}-01$ & -0.040 & 0.039 & $3.01 E-01$ & 0.020 & 0.042 & 6.34E-01 \\
\hline rs55786907 & $\mathrm{G} / \mathrm{A}$ & -0.030 & 0.054 & $5.75 \mathrm{E}-01$ & 0.102 & 0.055 & $6.43 \mathrm{E}-02$ & 0.037 & 0.042 & $3.82 \mathrm{E}-01$ & 0.025 & 0.045 & $5.74 \mathrm{E}-01$ \\
\hline rs9540731 & $\mathrm{C} / \mathrm{T}$ & -0.027 & 0.057 & $6.37 \mathrm{E}-01$ & -0.042 & 0.055 & $4.44 \mathrm{E}-01$ & -0.033 & 0.035 & $3.48 \mathrm{E}-01$ & -0.031 & 0.047 & 5.10E-01 \\
\hline rs9545155 & $\mathrm{T} / \mathrm{C}$ & -0.032 & 0.041 & 4.37E-01 & 0.007 & 0.042 & 8.72E-01 & 0.013 & 0.043 & 7.57E-01 & 0.005 & 0.034 & 8.89E-01 \\
\hline rs1772572 & $\mathrm{C} / \mathrm{A}$ & -0.040 & 0.043 & $3.51 \mathrm{E}-01$ & -0.017 & 0.044 & 7.04E-01 & -0.047 & 0.044 & 2.83E-01 & -0.060 & 0.036 & 8.98E-02 \\
\hline rs1108130 & $\mathrm{A} / \mathrm{T}$ & 0.031 & 0.053 & $5.54 \mathrm{E}-01$ & -0.037 & 0.054 & $4.94 \mathrm{E}-01$ & 0.024 & 0.041 & 5.59E-01 & -0.030 & 0.043 & 4.84E-01 \\
\hline rs12878369 & $\mathrm{A} / \mathrm{C}$ & -0.005 & 0.041 & $9.07 E-01$ & -0.044 & 0.053 & 4.10E-01 & -0.028 & 0.045 & 5.33E-01 & -0.029 & 0.043 & 5.10E-01 \\
\hline rs9323328 & $A / G$ & -0.037 & 0.042 & $3.76 \mathrm{E}-01$ & 0.022 & 0.041 & 5.89E-01 & -0.026 & 0.032 & $4.25 \mathrm{E}-01$ & 0.016 & 0.034 & 6.31E-01 \\
\hline rs1811739 & $A / G$ & 0.058 & 0.047 & 2.18E-01 & 0.069 & 0.048 & $1.52 \mathrm{E}-01$ & 0.044 & 0.037 & 2.33E-01 & 0.019 & 0.039 & 6.20E-01 \\
\hline rs8005334 & $\mathrm{G} / \mathrm{T}$ & 0.018 & 0.064 & 7.82E-01 & -0.041 & 0.044 & $3.45 \mathrm{E}-01$ & 0.004 & 0.034 & $9.14 \mathrm{E}-01$ & -0.025 & 0.036 & 4.84E-01 \\
\hline rs2925128 & $\mathrm{T} / \mathrm{C}$ & -0.067 & 0.065 & 3.05E-01 & -0.017 & 0.042 & $6.92 \mathrm{E}-01$ & -0.040 & 0.033 & 2.17E-01 & 0.015 & 0.045 & 7.36E-01 \\
\hline rs1381287 & $\mathrm{T} / \mathrm{C}$ & 0.004 & 0.041 & $9.31 \mathrm{E}-01$ & 0.024 & 0.042 & 5.58E-01 & 0.026 & 0.032 & $4.23 E-01$ & 0.033 & 0.034 & 3.37E-01 \\
\hline rs 1435672 & $\mathrm{C} / \mathrm{T}$ & 0.012 & 0.042 & $7.65 \mathrm{E}-01$ & -0.032 & 0.042 & $4.44 \mathrm{E}-01$ & -0.022 & 0.033 & 5.07E-01 & -0.027 & 0.048 & $5.75 \mathrm{E}-01$ \\
\hline rs281296 & $A / G$ & -0.080 & 0.043 & $6.09 \mathrm{E}-02$ & -0.038 & 0.043 & $3.76 \mathrm{E}-01$ & -0.045 & 0.033 & $1.73 \mathrm{E}-01$ & -0.052 & 0.036 & 1.47E-01 \\
\hline
\end{tabular}




\begin{tabular}{|c|c|c|c|c|c|c|c|c|c|c|c|c|c|}
\hline \multirow[b]{2}{*}{ SNP } & \multirow[b]{2}{*}{ EA/BA } & \multicolumn{3}{|c|}{$\begin{array}{c}\text { Age } \leq 67 y \\
\text { (2,878 cases; } 2,944 \text { controls) }\end{array}$} & \multicolumn{3}{|c|}{$\begin{array}{c}\text { Age }>67 y \\
\text { (3,208 cases; } 2,728 \text { controls })\end{array}$} & \multicolumn{3}{|c|}{$\begin{array}{c}\text { PD duration } \leq 7 y \\
(3,633 \text { cases; } 6,836 \text { controls })\end{array}$} & \multicolumn{3}{|c|}{$\begin{array}{c}\text { PD duration }>7 y \\
(3,271 \text { cases; } 6,836 \text { controls })\end{array}$} \\
\hline & & Beta & SE & P-value & Beta & SE & P-value & Beta & SE & P-value & Beta & SE & P-value \\
\hline rs2289791 & $\mathrm{G} / \mathrm{T}$ & \multicolumn{12}{|c|}{ Excluded for MR } \\
\hline rs62007780 & $\mathrm{G} / \mathrm{T}$ & -0.025 & 0.042 & 5.53E-01 & 0.036 & 0.042 & 3.87E-01 & -0.007 & 0.032 & 8.39E-01 & -0.008 & 0.035 & 8.07E-01 \\
\hline rs4310804 & $C / G$ & \multicolumn{12}{|c|}{ Excluded for MR } \\
\hline rs1139897 & $G / A$ & -0.001 & 0.051 & $9.90 \mathrm{E}-01$ & 0.070 & 0.052 & 1.83E-01 & 0.065 & 0.040 & 1.05E-01 & 0.035 & 0.042 & 4.13E-01 \\
\hline rs11076962 & $\mathrm{C} / \mathrm{T}$ & 0.020 & 0.047 & 6.64E-01 & -0.011 & 0.047 & 8.18E-01 & -0.002 & 0.036 & 9.61E-01 & 0.004 & 0.038 & $9.17 \mathrm{E}-01$ \\
\hline rs9922607 & $\mathrm{C} / \mathrm{T}$ & 0.018 & 0.051 & 7.31E-01 & -0.027 & 0.075 & 7.21E-01 & -0.044 & 0.040 & 2.66E-01 & 0.002 & 0.044 & $9.71 \mathrm{E}-01$ \\
\hline rs9941217 & $\mathrm{C} / \mathrm{G}$ & 0.004 & 0.044 & 9.33E-01 & 0.029 & 0.046 & $5.24 \mathrm{E}-01$ & -0.004 & 0.047 & $9.24 \mathrm{E}-01$ & -0.016 & 0.047 & 7.28E-01 \\
\hline rs6497840 & $\mathrm{A} / \mathrm{G}$ & -0.082 & 0.071 & $2.44 \mathrm{E}-01$ & 0.055 & 0.046 & $2.25 \mathrm{E}-01$ & 0.022 & 0.035 & 5.35E-01 & -0.048 & 0.038 & 2.00E-01 \\
\hline rs12918191 & $A / G$ & -0.009 & 0.047 & 8.44E-01 & -0.007 & 0.048 & 8.85E-01 & -0.016 & 0.037 & 6.57E-01 & 0.006 & 0.040 & 8.84E-01 \\
\hline rs9302604 & $\mathrm{G} / \mathrm{A}$ & -0.051 & 0.042 & 2.26E-01 & -0.068 & 0.055 & 2.13E-01 & -0.017 & 0.047 & 7.14E-01 & 0.021 & 0.035 & 5.44E-01 \\
\hline rs117657830 & $A / G$ & 0.108 & 0.107 & 3.16E-01 & -0.041 & 0.104 & $6.94 \mathrm{E}-01$ & -0.050 & 0.081 & 5.32E-01 & 0.037 & 0.090 & 6.82E-01 \\
\hline rs 1050847 & $\mathrm{C} / \mathrm{T}$ & 0.006 & 0.042 & $8.81 \mathrm{E}-01$ & -0.014 & 0.043 & 7.39E-01 & 0.019 & 0.033 & 5.69E-01 & -0.074 & 0.035 & 3.51E-02 \\
\hline rs11642231 & $G / A$ & 0.032 & 0.045 & 4.86E-01 & $\underline{0.09} \underline{4}$ & 0.045 & 3.95E-02 & 0.056 & 0.035 & $1.12 \mathrm{E}-01$ & 0.057 & 0.037 & $1.29 \mathrm{E}-01$ \\
\hline rs4790874 & $\mathrm{T} / \mathrm{C}$ & -0.050 & 0.042 & 2.33E-01 & -0.020 & 0.042 & 6.43E-01 & 0.002 & 0.033 & 9.46E-01 & -0.064 & 0.035 & $6.59 \mathrm{E}-02$ \\
\hline rs28441558 & $\mathrm{T} / \mathrm{C}$ & \multicolumn{12}{|c|}{ Excluded for MR } \\
\hline rs67777803 & $\mathrm{G} / \mathrm{T}$ & 0.056 & 0.054 & $3.08 \mathrm{E}-01$ & -0.065 & 0.057 & $2.50 \mathrm{E}-01$ & -0.049 & 0.054 & 3.69E-01 & -0.006 & 0.046 & 8.91E-01 \\
\hline rs3764351 & $\mathrm{G} / \mathrm{A}$ & -0.043 & 0.044 & $3.35 E-01$ & 0.001 & 0.058 & $9.86 \mathrm{E}-01$ & -0.026 & 0.035 & $4.62 \mathrm{E}-01$ & -0.045 & 0.037 & $2.26 \mathrm{E}-01$ \\
\hline rs72836318 & $\mathrm{T} / \mathrm{C}$ & -0.062 & 0.073 & 3.94E-01 & $\underline{-0.135}$ & 0.049 & 5.54E-03 & -0.068 & 0.038 & 7.09E-02 & $\underline{-0.124}$ & 0.040 & 1.85E-03 \\
\hline rs75919030 & $\mathrm{T} / \mathrm{C}$ & -0.019 & 0.047 & $6.84 \mathrm{E}-01$ & $\overline{0.003}$ & 0.048 & $9.55 \mathrm{E}-01$ & 0.014 & 0.037 & 7.12E-01 & -0.030 & 0.039 & 4.33E-01 \\
\hline rs2587507 & $\mathrm{T} / \mathrm{C}$ & -0.029 & 0.044 & 5.03E-01 & -0.037 & 0.041 & $3.61 \mathrm{E}-01$ & -0.046 & 0.034 & $1.72 \mathrm{E}-01$ & -0.022 & 0.034 & 5.08E-01 \\
\hline rs34342129 & $\mathrm{T} / \mathrm{C}$ & -0.011 & 0.042 & 7.92E-01 & -0.079 & 0.042 & 6.03E-02 & -0.057 & 0.032 & 7.66E-02 & -0.026 & 0.034 & 4.50E-01 \\
\hline rs4476253 & $G / A$ & 0.042 & 0.049 & 3.83E-01 & -0.021 & 0.075 & 7.81E-01 & -0.010 & 0.038 & 7.88E-01 & 0.024 & 0.056 & $6.73 \mathrm{E}-01$ \\
\hline rs8096225 & $\mathrm{C} / \mathrm{A}$ & -0.021 & 0.045 & 6.34E-01 & 0.045 & 0.045 & 3.18E-01 & 0.016 & 0.035 & 6.47E-01 & -0.033 & 0.037 & $3.76 \mathrm{E}-01$ \\
\hline rs67050670 & $A / G$ & 0.036 & 0.046 & 4.40E-01 & 0.057 & 0.048 & 2.35E-01 & 0.038 & 0.051 & 4.64E-01 & 0.051 & 0.039 & $1.94 \mathrm{E}-01$ \\
\hline rs1373178 & $\mathrm{T} / \mathrm{G}$ & -0.001 & 0.042 & $9.81 \mathrm{E}-01$ & -0.057 & 0.043 & 1.82E-01 & -0.042 & 0.033 & 2.01E-01 & -0.010 & 0.035 & 7.64E-01 \\
\hline rs72938304 & $\mathrm{G} / \mathrm{A}$ & 0.034 & 0.065 & 6.07E-01 & 0.113 & 0.067 & $9.06 \mathrm{E}-02$ & 0.104 & 0.070 & $1.38 \mathrm{E}-01$ & -0.033 & 0.054 & 5.47E-01 \\
\hline rs71367544 & $\mathrm{T} / \mathrm{C}$ & -0.059 & 0.054 & 2.74E-01 & 0.078 & 0.055 & 1.62E-01 & -0.011 & 0.043 & 8.03E-01 & 0.063 & 0.044 & 1.59E-01 \\
\hline rs76608582 & $\mathrm{C} / \mathrm{A}$ & \multicolumn{12}{|c|}{ NA in COURAGE-PD } \\
\hline rs10853981 & $\mathrm{A} / \mathrm{G}$ & 0.001 & 0.045 & $9.90 \mathrm{E}-01$ & -0.054 & 0.045 & 2.35E-01 & 0.004 & 0.044 & $9.22 \mathrm{E}-01$ & -0.020 & 0.037 & 5.79E-01 \\
\hline rs113230003 & $\mathrm{G} / \mathrm{A}$ & 0.020 & 0.071 & 7.78E-01 & 0.073 & 0.050 & $1.41 \mathrm{E}-01$ & 0.031 & 0.039 & 4.22E-01 & 0.047 & 0.041 & 2.59E-01 \\
\hline rs117734003 & $C / G$ & \multicolumn{12}{|c|}{ Excluded for MR } \\
\hline rs1126757 & $\mathrm{T} / \mathrm{C}$ & 0.030 & 0.042 & 4.73E-01 & -0.050 & 0.058 & 3.87E-01 & 0.015 & 0.035 & $6.75 \mathrm{E}-01$ & -0.017 & 0.039 & 6.61E-01 \\
\hline rs117495226 & $\mathrm{G} / \mathrm{A}$ & \multicolumn{6}{|c|}{ Excluded for MR } & -0.090 & 0.113 & 4.20E-01 & -0.041 & 0.121 & 7.40E-01 \\
\hline rs6073075 & $\mathrm{T} / \mathrm{A}$ & 0.063 & 0.052 & 2.26E-01 & -0.060 & 0.053 & $2.59 \mathrm{E}-01$ & 0.020 & 0.041 & $6.28 \mathrm{E}-01$ & -0.010 & 0.044 & 8.23E-01 \\
\hline rs3810496 & $\mathrm{C} / \mathrm{T}$ & -0.031 & 0.065 & $6.31 \mathrm{E}-01$ & -0.026 & 0.059 & 6.63E-01 & -0.047 & 0.046 & 3.07E-01 & -0.038 & 0.053 & 4.67E-01 \\
\hline rs4818005 & $\mathrm{G} / \mathrm{A}$ & -0.075 & 0.041 & $6.81 \mathrm{E}-02$ & 0.018 & 0.042 & $6.68 \mathrm{E}-01$ & -0.026 & 0.032 & 4.26E-01 & -0.056 & 0.034 & $1.06 \mathrm{E}-01$ \\
\hline rs4822102 & $\mathrm{C} / \mathrm{T}$ & 0.071 & 0.060 & 2.36E-01 & -0.006 & 0.043 & 8.98E-01 & 0.011 & 0.050 & 8.31E-01 & 0.021 & 0.035 & $5.48 \mathrm{E}-01$ \\
\hline
\end{tabular}

NA, not available; EA/BA, effect allele/base allele; SE, standard error.

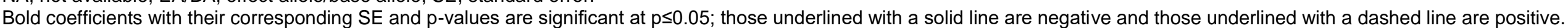


Supplementary table 5: Number of SNPs retained for each exposure in Mendelian randomization analyses and distribution of F-statistics.

\begin{tabular}{|c|c|c|c|c|c|}
\hline \multirow[b]{2}{*}{ Exposure } & \multicolumn{4}{|c|}{ Number of SNPs } & \multirow[b]{2}{*}{ F-statistic } \\
\hline & Total $^{\mathbf{a}}$ & Not available in Courage-PD & Excluded $^{b}$ & Retained for MR & \\
\hline Smoking initiation & 203 & 3 & 18 & 182 & 205.75 \\
\hline Lifetime smoking index & 126 & 1 & 12 & 113 & 20.03 \\
\hline Alcohol & 71 & 2 & 7 & 62 & 73.68 \\
\hline Coffee & 11 & - & - & 11 & 70.47 \\
\hline
\end{tabular}

a SNPs selected after clumping $\left(r^{2}=0.001\right.$, genomic region $\left.=10,000 \mathrm{~kb}\right)$.

b Ambiguous palindromic SNPs with MAF $\geq 0.42$, SNPs with MAF<0.01, or SNPs available in less than 17 studies.

c For each instrument, the F-statistic is given by the formula $\left(\frac{n-k-1}{k}\right)\left(\frac{R^{2}}{1-R^{2}}\right)$, with $R^{2}$ the proportion of variance explained by the genetic variants, $n$ the sample size, and $k$ the number of instruments. (Burgess S et al., Int J Epidemiol 2011;40(3):755-64). 


\section{Supplementary table 6: Mendelian randomization analyses stratified by age at study.}

\section{Age $\leq 67 y$}

(2,878 cases; 2,944 controls $)$

P-value P-het.

\section{Exposure}

Smoking initiation

Lifetime smoking

Alcohol drinking

Alcohol drinking after exclusion of 2 SNPs associated with coffee

Coffee drinking

Coffee drinking after exclusion of 2 SNPs associated with alcohol
OR

$0.68(0.48-0.97)$

$0.46(0.19-1.09)$

$0.51(0.22-1.16)$

$0.61(0.27-1.38)$

$1.15(0.25-5.33)$

$0.53(0.10-2.88)$
0.077

0.66

0.11

0.19

0.24

0.26

\section{Age $>67 y$}

(3,208 cases; 2,728 controls)

$0.031 \quad 0.92$

OR $\operatorname{lvw}(95 \% \mathrm{Cl})$

$0.83(0.58-1.18)$

$0.88(0.37-2.07)$

$0.85(0.39-1.83)$

0.68

0.93

$0.97(0.44-2.13)$

0.94

0.94

OR, odds ratio; IVW, inverse-variance weighted; $\mathrm{Cl}$, confidence interval; $\mathrm{p}$-het., $\mathrm{p}$ for heterogeneity; IVW, inverse variance weighted. 
Supplementary table 7: Mendelian randomization analyses stratified by disease duration in PD cases.

PD duration $\leq 7 y$

$(3,633$ cases; 6,836 controls)

\begin{tabular}{|c|c|c|c|c|c|c|}
\hline \multirow[b]{2}{*}{ Exposure } & \multirow[b]{2}{*}{ OR $_{\mathrm{IVw}}(95 \% \mathrm{Cl})$} & \multirow[b]{2}{*}{ P-value } & \multirow[b]{2}{*}{ P-het. } & \multirow[b]{2}{*}{ OR $_{\text {IVw }}(95 \% \mathrm{Cl})$} & \multirow[b]{2}{*}{ P-value } & \multirow[b]{2}{*}{ P-het. } \\
\hline & & & & & & \\
\hline Smoking initiation & $0.70(0.53-0.91)$ & 0.009 & 0.59 & $0.74(0.56-1.00)$ & 0.046 & 0.46 \\
\hline Lifetime smoking & $0.69(0.32-1.48)$ & 0.34 & 0.008 & $0.61(0.29-1.30)$ & 0.20 & 0.17 \\
\hline Alcohol drinking & $0.81(0.36-1.83)$ & 0.61 & 0.032 & $0.53(0.27-1.02)$ & 0.057 & 0.36 \\
\hline Alcohol drinking after exclusion of 2 SNPs associated with coffee & $1.03(0.46-2.31)$ & 0.95 & 0.075 & $0.59(0.30-1.16)$ & 0.13 & 0.38 \\
\hline Coffee drinking & $1.77(0.37-8.56)$ & 0.48 & 0.066 & $1.53(0.41-5.70)$ & 0.52 & 0.17 \\
\hline Coffee drinking after exclusion of 2 SNPs associated with alcohol & $0.55(0.11-2.85)$ & 0.48 & 0.31 & $1.05(0.22-4.98)$ & 0.95 & 0.24 \\
\hline
\end{tabular}

OR, odds ratio; IVW, inverse-variance weighted; Cl, confidence interval; p-het., p for heterogeneity; IVW, inverse variance weighted.
PD duration > 7y

\section{(3,271 cases; 6,836 controls)}

het

17

36

.38

17

.24 
Supplementary table 8: SNPs used for reverse Mendelian randomization analyses: individual associations with PD (exposure) and smoking, alcohol, and coffee drinking (outcomes).

\begin{tabular}{|c|c|c|c|c|c|c|c|c|c|c|c|}
\hline \multirow[b]{2}{*}{ SNP } & \multirow[b]{2}{*}{ Chr:Pos (GRCh37) } & \multirow[b]{2}{*}{ EA/BA } & \multicolumn{4}{|c|}{ PD (Nalls et al., 2019) } & \multicolumn{4}{|c|}{ Outcome } & \multirow[b]{2}{*}{$\mathbf{R}^{2}$} \\
\hline & & & EAF & Beta & SE & P-value & EAF & Beta & SE & P-value & \\
\hline \multicolumn{12}{|c|}{ Outcome: Alcohol drinking } \\
\hline rs35749011 & $1: 155135036$ & $A / G$ & 0.02 & 0.607 & 0.034 & $1.72 \mathrm{E}-70$ & 0.01 & -0.002 & 0.008 & $7.80 \mathrm{E}-01$ & $1.22 \mathrm{E}-02$ \\
\hline rs6658353 & $1: 161469054$ & $\mathrm{C} / \mathrm{G}$ & 0.50 & 0.065 & 0.009 & $6.10 \mathrm{E}-12$ & \multicolumn{5}{|c|}{ Excluded for reverse MR } \\
\hline rs11578699 & 1:171719769 & $\mathrm{C} / \mathrm{T}$ & 0.81 & 0.070 & 0.012 & 4.47E-09 & 0.80 & 0.002 & 0.002 & 3.08E-01 & $1.56 \mathrm{E}-03$ \\
\hline rs823118 & $1: 205723572$ & $\mathrm{~T} / \mathrm{C}$ & 0.57 & 0.107 & 0.009 & 1.11E-29 & 0.55 & $\underline{0.008}$ & 0.002 & 3.21E-05 & $5.58 \mathrm{E}-03$ \\
\hline rs4653767 & 1:226916078 & $\mathrm{T} / \mathrm{C}$ & 0.72 & 0.083 & 0.010 & $1.38 \mathrm{E}-15$ & 0.70 & $<0.001$ & 0.002 & $9.60 \mathrm{E}-01$ & $2.80 \mathrm{E}-03$ \\
\hline rs10797576 & $1: 232664611$ & $\mathrm{~T} / \mathrm{C}$ & 0.14 & 0.111 & 0.013 & $6.84 \mathrm{E}-17$ & 0.14 & 0.001 & 0.003 & 7.80E-01 & $2.99 \mathrm{E}-03$ \\
\hline rs76116224 & 2:18147848 & $A / T$ & 0.90 & 0.110 & 0.019 & 1.27E-08 & 0.91 & 0.003 & 0.003 & 4.29E-01 & $2.11 \mathrm{E}-03$ \\
\hline rs2042477 & $2: 96000943$ & T/A & 0.76 & 0.066 & 0.012 & 1.38E-08 & 0.75 & 0.001 & 0.002 & $8.15 \mathrm{E}-01$ & $1.58 \mathrm{E}-03$ \\
\hline rs 11683001 & $2: 102396963$ & $\mathrm{~A} / \mathrm{T}$ & 0.34 & 0.070 & 0.010 & $8.04 \mathrm{E}-13$ & 0.33 & 0.002 & 0.002 & 2.71E-01 & 2.22E-03 \\
\hline rs57891859 & $2: 135464616$ & $A / G$ & 0.72 & 0.081 & 0.011 & $4.55 \mathrm{E}-14$ & 0.69 & 0.001 & 0.002 & 7.86E-01 & 2.63E-03 \\
\hline rs1474055 & 2:169110394 & $\mathrm{T} / \mathrm{C}$ & 0.13 & 0.180 & 0.014 & 2.54E-39 & 0.13 & 0.004 & 0.003 & 2.29E-01 & 7.35E-03 \\
\hline rs73038319 & 3:18361759 & $\mathrm{C} / \mathrm{A}$ & 0.04 & 0.169 & 0.024 & $5.94 \mathrm{E}-13$ & 0.04 & 0.008 & 0.005 & 1.07E-01 & $2.24 \mathrm{E}-03$ \\
\hline rs6808178 & $3: 28705690$ & $\mathrm{~T} / \mathrm{C}$ & 0.38 & 0.066 & 0.010 & 8.09E-12 & 0.36 & 0.002 & 0.002 & $3.26 \mathrm{E}-01$ & $2.04 \mathrm{E}-03$ \\
\hline rs12497850 & 3:48748989 & $T / G$ & 0.65 & 0.064 & 0.010 & $1.36 \mathrm{E}-10$ & 0.64 & -0.001 & 0.002 & 5.16E-01 & $1.85 \mathrm{E}-03$ \\
\hline rs55961674 & 3:122196892 & $\mathrm{T} / \mathrm{C}$ & 0.17 & 0.086 & 0.013 & $9.98 \mathrm{E}-12$ & 0.16 & 0.003 & 0.003 & 2.21E-01 & $2.11 \mathrm{E}-03$ \\
\hline rs11707416 & 3:151108965 & $T / A$ & 0.63 & 0.063 & 0.010 & 1.13E-10 & 0.64 & 0.003 & 0.002 & 9.36E-02 & 1.83E-03 \\
\hline rs10513789 & $3: 182760073$ & $T / G$ & 0.81 & 0.148 & 0.012 & $1.22 E-34$ & 0.79 & 0.003 & 0.002 & 2.03E-01 & $6.75 \mathrm{E}-03$ \\
\hline rs34311866 & $4: 951947$ & $\mathrm{C} / \mathrm{T}$ & 0.19 & 0.213 & 0.012 & $9.98 \mathrm{E}-70$ & 0.18 & -0.004 & 0.003 & 1.03E-01 & $1.41 \mathrm{E}-02$ \\
\hline rs4698412 & 4:15737348 & $A / G$ & 0.55 & 0.104 & 0.009 & 2.06E-28 & 0.54 & 0.003 & 0.002 & $1.84 \mathrm{E}-01$ & 5.30E-03 \\
\hline rs6854006 & 4:77198054 & $\mathrm{C} / \mathrm{T}$ & 0.64 & 0.091 & 0.010 & $5.82 E-21$ & 0.64 & $\underline{-0.006}$ & 0.002 & 1.21E-03 & $3.85 \mathrm{E}-03$ \\
\hline rs356182 & 4:90626111 & $G / A$ & 0.37 & 0.277 & 0.011 & $3.89 E-154$ & 0.35 & $\overline{0.002}$ & 0.002 & 4.42E-01 & 3.60E-02 \\
\hline rs13117519 & $4: 114369065$ & $\mathrm{~T} / \mathrm{C}$ & 0.17 & 0.088 & 0.012 & $9.82 \mathrm{E}-13$ & 0.16 & $\underline{-0.008}$ & 0.003 & 3.76E-03 & 2.20E-03 \\
\hline rs62333164 & $4: 170583157$ & $G / A$ & 0.67 & 0.064 & 0.010 & $2.00 \mathrm{E}-10$ & 0.67 & $\overline{-0.001}$ & 0.002 & 7.06E-01 & 1.79E-03 \\
\hline rs1867598 & 5:60137959 & $G / A$ & 0.10 & 0.155 & 0.016 & $2.52 E-23$ & 0.09 & -0.002 & 0.003 & $4.85 \mathrm{E}-01$ & 4.27E-03 \\
\hline rs26431 & 5:102365794 & $\mathrm{C} / \mathrm{G}$ & 0.70 & 0.062 & 0.010 & 1.57E-09 & 0.70 & -0.002 & 0.002 & 3.76E-01 & $1.61 \mathrm{E}-03$ \\
\hline rs11950533 & 5:134199105 & $\mathrm{C} / \mathrm{A}$ & 0.90 & 0.092 & 0.016 & 7.16E-09 & 0.88 & -0.003 & 0.003 & 3.20E-01 & 1.54E-03 \\
\hline rs12528068 & 6:72487762 & $\mathrm{T} / \mathrm{C}$ & 0.28 & 0.066 & 0.010 & $1.63 \mathrm{E}-10$ & 0.28 & 0.004 & 0.002 & $9.82 \mathrm{E}-02$ & 1.76E-03 \\
\hline rs997368 & 6:112243291 & $A / G$ & 0.80 & 0.071 & 0.012 & 1.84E-09 & 0.79 & -0.001 & 0.003 & 7.74E-01 & $1.60 \mathrm{E}-03$ \\
\hline rs75859381 & $6: 133210361$ & $\mathrm{C} / \mathrm{T}$ & 0.03 & 0.221 & 0.034 & $1.04 \mathrm{E}-10$ & 0.03 & 0.005 & 0.006 & 3.97E-01 & $3.08 \mathrm{E}-03$ \\
\hline rs199351 & 7:23300049 & $\mathrm{A} / \mathrm{C}$ & 0.59 & 0.102 & 0.010 & $5.25 \mathrm{E}-26$ & 0.57 & $<0.001$ & 0.002 & $9.38 \mathrm{E}-01$ & $4.98 \mathrm{E}-03$ \\
\hline rs76949143 & 7:66009851 & $\mathrm{T} / \mathrm{A}$ & 0.95 & 0.143 & 0.025 & 1.43E-08 & 0.94 & 0.009 & 0.004 & 4.49E-02 & 1.97E-03 \\
\hline rs1293298 & $8: 11712443$ & $A / C$ & 0.74 & 0.093 & 0.011 & 3.99E-16 & 0.76 & $-\overline{-0.003}$ & 0.002 & $1.75 \mathrm{E}-01$ & 3.29E-03 \\
\hline rs2280104 & 8:22525980 & $\mathrm{T} / \mathrm{C}$ & 0.36 & 0.056 & 0.010 & 1.16E-08 & 0.35 & -0.004 & 0.002 & $5.44 \mathrm{E}-02$ & 1.43E-03 \\
\hline rs2086641 & 8:130901909 & $\mathrm{C} / \mathrm{T}$ & 0.28 & 0.060 & 0.011 & 1.81E-08 & 0.26 & -0.002 & 0.002 & 2.82E-01 & 1.47E-03 \\
\hline rs13294100 & 9:17579690 & $\mathrm{G} / \mathrm{T}$ & 0.66 & 0.086 & 0.010 & $8.72 \mathrm{E}-18$ & 0.63 & 0.001 & 0.002 & $6.44 \mathrm{E}-01$ & 3.32E-03 \\
\hline rs6476434 & $9: 34046391$ & $\mathrm{C} / \mathrm{T}$ & 0.27 & 0.062 & 0.011 & $6.58 \mathrm{E}-09$ & 0.26 & $\underline{0.008}$ & 0.002 & 2.06E-04 & $1.48 \mathrm{E}-03$ \\
\hline rs896435 & $10: 15557406$ & $\mathrm{~T} / \mathrm{C}$ & 0.69 & 0.074 & 0.010 & $3.41 E-13$ & 0.67 & $\overline{-0.003}$ & 0.002 & 1.39E-01 & 2.31E-03 \\
\hline rs10748818 & 10:104015279 & $G / A$ & 0.15 & 0.079 & 0.013 & 1.05E-09 & 0.14 & $\underline{-0.006}$ & 0.003 & 4.30E-02 & $1.58 \mathrm{E}-03$ \\
\hline rs117896735 & $10: 121536327$ & $\mathrm{~A} / \mathrm{G}$ & 0.02 & 0.435 & 0.039 & 2.36E-28 & 0.01 & $\overline{0.003}$ & 0.007 & 6.47E-01 & $6.19 \mathrm{E}-03$ \\
\hline rs7938782 & $11: 10558777$ & $A / G$ & 0.88 & 0.087 & 0.015 & 2.12E-09 & 0.86 & 0.001 & 0.003 & $7.58 \mathrm{E}-01$ & 1.63E-03 \\
\hline rs12283611 & $11: 83487277$ & $\mathrm{C} / \mathrm{A}$ & 0.59 & 0.064 & 0.010 & $2.61 \mathrm{E}-10$ & 0.57 & -0.001 & 0.002 & $5.01 \mathrm{E}-01$ & 2.02E-03 \\
\hline rs3802920 & 11:133787001 & $T / G$ & 0.21 & 0.107 & 0.012 & $6.26 \mathrm{E}-20$ & 0.20 & 0.004 & 0.002 & $1.10 \mathrm{E}-01$ & 3.76E-03 \\
\hline rs76904798 & $12: 40614434$ & $\mathrm{~T} / \mathrm{C}$ & 0.14 & 0.144 & 0.013 & $1.52 E-28$ & 0.13 & 0.003 & 0.003 & 3.17E-01 & $5.12 \mathrm{E}-03$ \\
\hline rs7134559 & $12: 46419086$ & $\mathrm{C} / \mathrm{T}$ & 0.60 & 0.054 & 0.010 & 3.96E-08 & 0.61 & $\underline{0.007}$ & 0.002 & 4.06E-04 & 1.40E-03 \\
\hline
\end{tabular}




\begin{tabular}{|c|c|c|c|c|c|c|c|c|c|c|c|}
\hline \multirow[b]{2}{*}{ SNP } & \multirow[b]{2}{*}{ Chr:Pos (GRCh37) } & \multirow[b]{2}{*}{ EA/BA } & \multicolumn{4}{|c|}{ PD (Nalls et al., 2019) } & \multicolumn{4}{|c|}{ Outcome } & \multirow[b]{2}{*}{$\mathbf{R}^{2}$} \\
\hline & & & EAF & Beta & SE & P-value & EAF & Beta & SE & P-value & \\
\hline rs10847864 & 12:123326598 & $\mathrm{T} / \mathrm{G}$ & 0.36 & 0.148 & 0.012 & 1.47E-37 & 0.35 & 0.004 & 0.002 & 8.08E-02 & $1.01 \mathrm{E}-02$ \\
\hline rs9568188 & 13:49927732 & $\mathrm{T} / \mathrm{C}$ & 0.74 & 0.062 & 0.011 & $1.15 \mathrm{E}-08$ & 0.72 & 0.007 & 0.002 & 8.55E-04 & 1.47E-03 \\
\hline rs4771268 & 13:97865021 & $\mathrm{T} / \mathrm{C}$ & 0.23 & 0.068 & 0.011 & 1.45E-09 & 0.24 & $\overline{0.004}$ & 0.002 & 5.31E-02 & $1.61 \mathrm{E}-03$ \\
\hline rs12147950 & $14: 37989270$ & $\mathrm{C} / \mathrm{T}$ & 0.56 & 0.053 & 0.010 & 3.54E-08 & 0.56 & 0.003 & 0.002 & $1.74 \mathrm{E}-01$ & $1.38 \mathrm{E}-03$ \\
\hline rs11158026 & $14: 55348869$ & $\mathrm{C} / \mathrm{T}$ & 0.68 & 0.084 & 0.010 & $1.66 \mathrm{E}-16$ & 0.66 & -0.001 & 0.002 & 7.35E-01 & $3.11 \mathrm{E}-03$ \\
\hline rs3742785 & $14: 75373034$ & $\mathrm{~A} / \mathrm{C}$ & 0.79 & 0.071 & 0.012 & 1.92E-09 & 0.77 & -0.004 & 0.002 & $1.27 \mathrm{E}-01$ & $1.68 \mathrm{E}-03$ \\
\hline rs979812 & $14: 88464264$ & $T / G$ & 0.44 & 0.061 & 0.009 & $6.19 \mathrm{E}-11$ & 0.44 & 0.004 & 0.002 & 2.31E-02 & $1.84 \mathrm{E}-03$ \\
\hline rs2251086 & 15:61997385 & $\mathrm{C} / \mathrm{T}$ & 0.86 & 0.119 & 0.014 & $6.08 \mathrm{E}-18$ & 0.84 & $\overline{0.008}$ & 0.003 & $5.45 \mathrm{E}-03$ & $3.42 \mathrm{E}-03$ \\
\hline rs6497339 & $16: 19277493$ & $\mathrm{~A} / \mathrm{T}$ & 0.45 & 0.063 & 0.010 & $2.76 \mathrm{E}-11$ & \multicolumn{5}{|c|}{ Excluded for reverse MR } \\
\hline rs11150601 & 16:30977799 & $A / G$ & 0.64 & 0.091 & 0.010 & $5.12 \mathrm{E}-20$ & 0.63 & $\underline{0.004}$ & 0.002 & 3.90E-02 & 3.77E-03 \\
\hline rs3104783 & $16: 52636242$ & $\mathrm{~A} / \mathrm{C}$ & 0.43 & 0.067 & 0.009 & $1.29 \mathrm{E}-12$ & 0.44 & $-\overline{-0.003}$ & 0.002 & $1.95 \mathrm{E}-01$ & 2.19E-03 \\
\hline rs12600861 & $17: 7355621$ & $\mathrm{C} / \mathrm{A}$ & 0.35 & 0.056 & 0.010 & $1.01 \mathrm{E}-08$ & 0.35 & -0.003 & 0.002 & $1.04 \mathrm{E}-01$ & 1.46E-03 \\
\hline rs850738 & $17: 42434630$ & $\mathrm{G} / \mathrm{A}$ & 0.39 & 0.071 & 0.011 & $1.29 \mathrm{E}-11$ & 0.39 & 0.003 & 0.002 & $1.89 \mathrm{E}-01$ & $2.41 \mathrm{E}-03$ \\
\hline rs62053943 & $17: 43744203$ & $\mathrm{C} / \mathrm{T}$ & 0.84 & 0.270 & 0.016 & $3.58 \mathrm{E}-68$ & 0.86 & $\underline{0.017}$ & 0.003 & $6.83 \mathrm{E}-10$ & 1.91E-02 \\
\hline rs61169879 & $17: 59917366$ & $\mathrm{~T} / \mathrm{C}$ & 0.16 & 0.082 & 0.013 & $9.28 \mathrm{E}-10$ & 0.17 & 0.005 & 0.003 & 4.52E-02 & $1.84 \mathrm{E}-03$ \\
\hline rs666463 & $17: 76425480$ & $A / T$ & 0.83 & 0.076 & 0.013 & 3.20E-09 & 0.84 & $\overline{<0.001}$ & 0.003 & $9.20 \mathrm{E}-01$ & $1.61 \mathrm{E}-03$ \\
\hline rs1941685 & $18: 31304318$ & $\mathrm{~T} / \mathrm{G}$ & 0.50 & 0.053 & 0.009 & $1.69 \mathrm{E}-08$ & 0.52 & $<0.001$ & 0.002 & 8.23E-01 & $1.41 \mathrm{E}-03$ \\
\hline rs12456492 & $18: 40673380$ & $G / A$ & 0.32 & 0.098 & 0.010 & $3.80 \mathrm{E}-23$ & 0.32 & $\underline{0.007}$ & 0.002 & 9.12E-04 & 4.19E-03 \\
\hline rs8087969 & $18: 48683589$ & $\mathrm{G} / \mathrm{T}$ & 0.45 & 0.058 & 0.010 & $1.41 \mathrm{E}-08$ & 0.44 & 0.001 & 0.002 & 4.92E-01 & $1.65 \mathrm{E}-03$ \\
\hline rs55818311 & $19: 2341047$ & $\mathrm{C} / \mathrm{T}$ & 0.31 & 0.070 & 0.011 & $4.18 \mathrm{E}-10$ & 0.33 & 0.002 & 0.002 & 2.27E-01 & 2.06E-03 \\
\hline rs77351827 & $20: 6006041$ & $\mathrm{~T} / \mathrm{C}$ & 0.13 & 0.080 & 0.014 & 8.87E-09 & 0.12 & -0.001 & 0.003 & 8.50E-01 & 1.43E-03 \\
\hline rs2248244 & $21: 38852361$ & $\mathrm{~A} / \mathrm{G}$ & 0.28 & 0.071 & 0.011 & $2.74 \mathrm{E}-11$ & 0.28 & -0.003 & 0.002 & $1.28 \mathrm{E}-01$ & 2.07E-03 \\
\hline \multicolumn{12}{|c|}{ Outcome: Coffee drinking } \\
\hline rs35749011 & $1: 155135036$ & $A / G$ & 0.02 & 0.607 & 0.034 & 1.72E-70 & 0.01 & $<0.001$ & 0.007 & $9.60 \mathrm{E}-01$ & 1.22E-02 \\
\hline rs6658353 & $1: 161469054$ & $\mathrm{C} / \mathrm{G}$ & 0.50 & 0.065 & 0.009 & $6.10 \mathrm{E}-12$ & \multicolumn{5}{|c|}{ Excluded for reverse MR } \\
\hline rs11578699 & 1:171719769 & $\mathrm{C} / \mathrm{T}$ & 0.81 & 0.070 & 0.012 & 4.47E-09 & 0.80 & 0.002 & 0.002 & 4.16E-01 & 1.56E-03 \\
\hline rs823118 & 1:205723572 & $T / C$ & 0.57 & 0.107 & 0.009 & $1.11 \mathrm{E}-29$ & 0.55 & -0.001 & 0.002 & 3.79E-01 & $5.58 \mathrm{E}-03$ \\
\hline rs4653767 & $1: 226916078$ & $\mathrm{~T} / \mathrm{C}$ & 0.72 & 0.083 & 0.010 & $1.38 \mathrm{E}-15$ & 0.72 & $<0.001$ & 0.002 & 8.75E-01 & $2.80 \mathrm{E}-03$ \\
\hline rs10797576 & $1: 232664611$ & $\mathrm{~T} / \mathrm{C}$ & 0.14 & 0.111 & 0.013 & $6.84 \mathrm{E}-17$ & 0.12 & -0.002 & 0.002 & 3.16E-01 & 2.99E-03 \\
\hline rs76116224 & $2: 18147848$ & $A / T$ & 0.90 & 0.110 & 0.019 & 1.27E-08 & 0.90 & -0.002 & 0.003 & 3.66E-01 & $2.11 \mathrm{E}-03$ \\
\hline rs2042477 & $2: 96000943$ & $\mathrm{~T} / \mathrm{A}$ & 0.76 & 0.066 & 0.012 & $1.38 \mathrm{E}-08$ & 0.74 & 0.002 & 0.002 & $1.90 \mathrm{E}-01$ & $1.58 \mathrm{E}-03$ \\
\hline rs11683001 & $2: 102396963$ & $\mathrm{~A} / \mathrm{T}$ & 0.34 & 0.070 & 0.010 & 8.04E-13 & 0.34 & $<0.001$ & 0.002 & 7.90E-01 & 2.22E-03 \\
\hline rs57891859 & $2: 135464616$ & $A / G$ & 0.72 & 0.081 & 0.011 & $4.55 \mathrm{E}-14$ & 0.75 & 0.002 & 0.002 & 3.94E-01 & 2.63E-03 \\
\hline rs1474055 & $2: 169110394$ & $\mathrm{~T} / \mathrm{C}$ & 0.13 & 0.180 & 0.014 & 2.54E-39 & 0.12 & 0.003 & 0.002 & 2.51E-01 & 7.35E-03 \\
\hline rs73038319 & $3: 18361759$ & $\mathrm{C} / \mathrm{A}$ & 0.04 & 0.169 & 0.024 & $5.94 \mathrm{E}-13$ & 0.04 & $<0.001$ & 0.004 & $9.15 \mathrm{E}-01$ & $2.24 \mathrm{E}-03$ \\
\hline rs6808178 & $3: 28705690$ & $\mathrm{~T} / \mathrm{C}$ & 0.38 & 0.066 & 0.010 & $8.09 \mathrm{E}-12$ & 0.38 & 0.001 & 0.002 & 4.74E-01 & 2.04E-03 \\
\hline rs12497850 & $3: 48748989$ & $\mathrm{~T} / \mathrm{G}$ & 0.65 & 0.064 & 0.010 & $1.36 \mathrm{E}-10$ & 0.65 & 0.004 & 0.002 & 6.44E-03 & $1.85 \mathrm{E}-03$ \\
\hline rs55961674 & 3:122196892 & $\mathrm{T} / \mathrm{C}$ & 0.17 & 0.086 & 0.013 & $9.98 \mathrm{E}-12$ & 0.15 & $\overline{0.002}$ & 0.002 & 3.26E-01 & $2.11 \mathrm{E}-03$ \\
\hline rs11707416 & $3: 151108965$ & $\mathrm{~T} / \mathrm{A}$ & 0.63 & 0.063 & 0.010 & $1.13 \mathrm{E}-10$ & 0.63 & -0.001 & 0.002 & 5.21E-01 & 1.83E-03 \\
\hline rs10513789 & $3: 182760073$ & $\mathrm{~T} / \mathrm{G}$ & 0.81 & 0.148 & 0.012 & 1.22E-34 & 0.81 & $<0.001$ & 0.002 & 9.52E-01 & $6.75 \mathrm{E}-03$ \\
\hline rs34311866 & $4: 951947$ & $\mathrm{C} / \mathrm{T}$ & 0.19 & 0.213 & 0.012 & $9.98 \mathrm{E}-70$ & 0.18 & 0.001 & 0.002 & $6.12 \mathrm{E}-01$ & $1.41 \mathrm{E}-02$ \\
\hline rs4698412 & $4: 15737348$ & $A / G$ & 0.55 & 0.104 & 0.009 & $2.06 \mathrm{E}-28$ & 0.55 & $<0.001$ & 0.002 & 8.79E-01 & $5.30 \mathrm{E}-03$ \\
\hline rs6854006 & $4: 77198054$ & $\mathrm{C} / \mathrm{T}$ & 0.64 & 0.091 & 0.010 & $5.82 \mathrm{E}-21$ & 0.62 & -0.001 & 0.002 & 7.34E-01 & $3.85 \mathrm{E}-03$ \\
\hline rs356182 & 4:90626111 & $G / A$ & 0.37 & 0.277 & 0.011 & $3.89 E-154$ & 0.34 & $<0.001$ & 0.002 & 8.71E-01 & $3.60 \mathrm{E}-02$ \\
\hline rs13117519 & $4: 114369065$ & $\mathrm{~T} / \mathrm{C}$ & 0.17 & 0.088 & 0.012 & $9.82 \mathrm{E}-13$ & 0.17 & -0.001 & 0.002 & $6.43 E-01$ & 2.20E-03 \\
\hline rs62333164 & $4: 170583157$ & $\mathrm{G} / \mathrm{A}$ & 0.67 & 0.064 & 0.010 & $2.00 \mathrm{E}-10$ & 0.67 & 0.002 & 0.002 & $2.01 \mathrm{E}-01$ & 1.79E-03 \\
\hline rs1867598 & 5:60137959 & $\mathrm{G} / \mathrm{A}$ & 0.10 & 0.155 & 0.016 & $2.52 \mathrm{E}-23$ & 0.08 & 0.007 & 0.003 & 2.38E-02 & 4.27E-03 \\
\hline
\end{tabular}




\begin{tabular}{|c|c|c|c|c|c|c|c|c|c|c|c|}
\hline \multirow[b]{2}{*}{ SNP } & \multirow[b]{2}{*}{ Chr:Pos (GRCh37) } & \multirow[b]{2}{*}{ EA/BA } & \multicolumn{4}{|c|}{ PD (Nalls et al., 2019) } & \multicolumn{4}{|c|}{ Outcome } & \multirow[b]{2}{*}{$\mathbf{R}^{2}$} \\
\hline & & & EAF & Beta & SE & P-value & EAF & Beta & SE & P-value & \\
\hline rs26431 & $5: 102365794$ & $\mathrm{C} / \mathrm{G}$ & 0.70 & 0.062 & 0.010 & 1.57E-09 & 0.69 & -0.001 & 0.002 & 3.83E-01 & $1.61 \mathrm{E}-03$ \\
\hline rs11950533 & 5:134199105 & $\mathrm{C} / \mathrm{A}$ & 0.90 & 0.092 & 0.016 & 7.16E-09 & 0.90 & 0.003 & 0.003 & $2.36 \mathrm{E}-01$ & $1.54 \mathrm{E}-03$ \\
\hline rs112485576 & $6: 32578772$ & $\mathrm{C} / \mathrm{A}$ & 0.84 & 0.168 & 0.015 & $6.96 \mathrm{E}-28$ & 0.81 & $\underline{0.005}$ & 0.002 & 1.63E-02 & 7.66E-03 \\
\hline rs12528068 & $6: 72487762$ & $\mathrm{~T} / \mathrm{C}$ & 0.28 & 0.066 & 0.010 & $1.63 \mathrm{E}-10$ & 0.28 & $\overline{0.003}$ & 0.002 & $1.28 \mathrm{E}-01$ & 1.76E-03 \\
\hline rs997368 & $6: 112243291$ & $A / G$ & 0.80 & 0.071 & 0.012 & 1.84E-09 & 0.82 & 0.003 & 0.002 & $1.87 \mathrm{E}-01$ & $1.60 \mathrm{E}-03$ \\
\hline rs75859381 & $6: 133210361$ & $\mathrm{C} / \mathrm{T}$ & 0.03 & 0.221 & 0.034 & $1.04 \mathrm{E}-10$ & 0.03 & 0.001 & 0.005 & $8.48 \mathrm{E}-01$ & $3.08 \mathrm{E}-03$ \\
\hline rs199351 & 7:23300049 & $A / C$ & 0.59 & 0.102 & 0.010 & $5.25 E-26$ & 0.59 & -0.001 & 0.002 & 5.75E-01 & 4.98E-03 \\
\hline rs76949143 & $7: 66009851$ & $\mathrm{~T} / \mathrm{A}$ & 0.95 & 0.143 & 0.025 & $1.43 \mathrm{E}-08$ & 0.95 & -0.004 & 0.004 & $2.38 \mathrm{E}-01$ & 1.97E-03 \\
\hline rs1293298 & $8: 11712443$ & $\mathrm{~A} / \mathrm{C}$ & 0.74 & 0.093 & 0.011 & $3.99 \mathrm{E}-16$ & 0.74 & 0.004 & 0.002 & 3.34E-02 & $3.29 E-03$ \\
\hline rs2280104 & $8: 22525980$ & $\mathrm{~T} / \mathrm{C}$ & 0.36 & 0.056 & 0.010 & $1.16 \mathrm{E}-08$ & 0.35 & -0.001 & 0.002 & 4.61E-01 & 1.43E-03 \\
\hline rs2086641 & 8:130901909 & $\mathrm{C} / \mathrm{T}$ & 0.28 & 0.060 & 0.011 & $1.81 \mathrm{E}-08$ & 0.26 & $<0.001$ & 0.002 & 8.43E-01 & 1.47E-03 \\
\hline rs13294100 & 9:17579690 & $\mathrm{G} / \mathrm{T}$ & 0.66 & 0.086 & 0.010 & $8.72 \mathrm{E}-18$ & 0.65 & 0.001 & 0.002 & 6.77E-01 & 3.32E-03 \\
\hline rs6476434 & 9:34046391 & $\mathrm{C} / \mathrm{T}$ & 0.27 & 0.062 & 0.011 & 6.58E-09 & 0.27 & -0.001 & 0.002 & 4.28E-01 & $1.48 \mathrm{E}-03$ \\
\hline rs896435 & $10: 15557406$ & $\mathrm{~T} / \mathrm{C}$ & 0.69 & 0.074 & 0.010 & $3.41 \mathrm{E}-13$ & 0.68 & 0.002 & 0.002 & 3.35E-01 & 2.31E-03 \\
\hline rs10748818 & 10:104015279 & $\mathrm{G} / \mathrm{A}$ & 0.15 & 0.079 & 0.013 & 1.05E-09 & 0.15 & -0.001 & 0.002 & 8.14E-01 & $1.58 \mathrm{E}-03$ \\
\hline rs117896735 & 10:121536327 & $A / G$ & 0.02 & 0.435 & 0.039 & $2.36 \mathrm{E}-28$ & 0.02 & -0.002 & 0.006 & 7.05E-01 & 6.19E-03 \\
\hline rs7938782 & 11:10558777 & $A / G$ & 0.88 & 0.087 & 0.015 & 2.12E-09 & 0.88 & $\underline{0.007}$ & 0.002 & 3.36E-03 & 1.63E-03 \\
\hline rs12283611 & $11: 83487277$ & $\mathrm{C} / \mathrm{A}$ & 0.59 & 0.064 & 0.010 & $2.61 \mathrm{E}-10$ & 0.59 & $\overline{0.001}$ & 0.002 & $6.20 \mathrm{E}-01$ & 2.02E-03 \\
\hline rs3802920 & $11: 133787001$ & $T / G$ & 0.21 & 0.107 & 0.012 & $6.26 \mathrm{E}-20$ & 0.20 & -0.002 & 0.002 & $2.51 \mathrm{E}-01$ & $3.76 \mathrm{E}-03$ \\
\hline rs76904798 & 12:40614434 & $\mathrm{T} / \mathrm{C}$ & 0.14 & 0.144 & 0.013 & $1.52 \mathrm{E}-28$ & 0.14 & -0.003 & 0.002 & 2.09E-01 & $5.12 \mathrm{E}-03$ \\
\hline rs7134559 & $12: 46419086$ & $\mathrm{C} / \mathrm{T}$ & 0.60 & 0.054 & 0.010 & 3.96E-08 & 0.60 & 0.001 & 0.002 & 4.01E-01 & $1.40 \mathrm{E}-03$ \\
\hline rs10847864 & $12: 123326598$ & $\mathrm{~T} / \mathrm{G}$ & 0.36 & 0.148 & 0.012 & 1.47E-37 & 0.35 & -0.001 & 0.002 & 3.89E-01 & $1.01 \mathrm{E}-02$ \\
\hline rs9568188 & 13:49927732 & $\mathrm{T} / \mathrm{C}$ & 0.74 & 0.062 & 0.011 & 1.15E-08 & 0.73 & $<0.001$ & 0.002 & 7.92E-01 & 1.47E-03 \\
\hline rs4771268 & 13:97865021 & $\mathrm{T} / \mathrm{C}$ & 0.23 & 0.068 & 0.011 & 1.45E-09 & 0.22 & $<0.001$ & 0.002 & 8.36E-01 & 1.61E-03 \\
\hline rs12147950 & 14:37989270 & $\mathrm{C} / \mathrm{T}$ & 0.56 & 0.053 & 0.010 & 3.54E-08 & 0.57 & 0.001 & 0.002 & 4.10E-01 & 1.38E-03 \\
\hline rs11158026 & $14: 55348869$ & $\mathrm{C} / \mathrm{T}$ & 0.68 & 0.084 & 0.010 & $1.66 \mathrm{E}-16$ & 0.66 & 0.002 & 0.002 & 2.33E-01 & 3.11E-03 \\
\hline rs3742785 & $14: 75373034$ & $\mathrm{~A} / \mathrm{C}$ & 0.79 & 0.071 & 0.012 & 1.92E-09 & 0.78 & -0.005 & 0.002 & 1.13E-02 & $1.68 \mathrm{E}-03$ \\
\hline rs979812 & $14: 88464264$ & $\mathrm{~T} / \mathrm{G}$ & 0.44 & 0.061 & 0.009 & $6.19 \mathrm{E}-11$ & 0.42 & -0.001 & 0.002 & 4.81E-01 & $1.84 \mathrm{E}-03$ \\
\hline rs2251086 & 15:61997385 & $\mathrm{C} / \mathrm{T}$ & 0.86 & 0.119 & 0.014 & $6.08 \mathrm{E}-18$ & 0.86 & 0.004 & 0.002 & 7.31E-02 & $3.42 \mathrm{E}-03$ \\
\hline rs6497339 & $16: 19277493$ & $\mathrm{~A} / \mathrm{T}$ & 0.45 & 0.063 & 0.010 & $2.76 \mathrm{E}-11$ & & & uded for & erse MR & \\
\hline rs11150601 & 16:30977799 & $A / G$ & 0.64 & 0.091 & 0.010 & 5.12E-20 & 0.63 & -0.001 & 0.002 & 6.47E-01 & 3.77E-03 \\
\hline rs3104783 & $16: 52636242$ & $A / C$ & 0.43 & 0.067 & 0.009 & 1.29E-12 & 0.41 & $<0.001$ & 0.002 & 9.08E-01 & 2.19E-03 \\
\hline rs12600861 & $17: 7355621$ & $\mathrm{C} / \mathrm{A}$ & 0.35 & 0.056 & 0.010 & $1.01 \mathrm{E}-08$ & 0.36 & $<0.001$ & 0.002 & 7.89E-01 & 1.46E-03 \\
\hline rs850738 & $17: 42434630$ & $\mathrm{G} / \mathrm{A}$ & 0.39 & 0.071 & 0.011 & $1.29 \mathrm{E}-11$ & 0.39 & 0.002 & 0.002 & $1.81 \mathrm{E}-01$ & $2.41 \mathrm{E}-03$ \\
\hline rs62053943 & $17: 43744203$ & $\mathrm{C} / \mathrm{T}$ & 0.84 & 0.270 & 0.016 & $3.58 \mathrm{E}-68$ & 0.84 & -0.001 & 0.002 & 6.85E-01 & 1.91E-02 \\
\hline rs61169879 & 17:59917366 & $\mathrm{T} / \mathrm{C}$ & 0.16 & 0.082 & 0.013 & $9.28 \mathrm{E}-10$ & 0.16 & $\underline{0.012}$ & 0.002 & 4.00E-08 & $1.84 \mathrm{E}-03$ \\
\hline rs666463 & $17: 76425480$ & $\mathrm{~A} / \mathrm{T}$ & 0.83 & 0.076 & 0.013 & 3.20E-09 & 0.83 & $\overline{0.001}$ & 0.002 & $6.75 \mathrm{E}-01$ & $1.61 \mathrm{E}-03$ \\
\hline rs1941685 & 18:31304318 & $\mathrm{T} / \mathrm{G}$ & 0.50 & 0.053 & 0.009 & $1.69 \mathrm{E}-08$ & 0.50 & $<0.001$ & 0.002 & $9.46 \mathrm{E}-01$ & 1.41E-03 \\
\hline rs12456492 & $18: 40673380$ & $\mathrm{G} / \mathrm{A}$ & 0.32 & 0.098 & 0.010 & $3.80 \mathrm{E}-23$ & 0.31 & $\underline{-0.005}$ & 0.002 & 1.98E-03 & 4.19E-03 \\
\hline rs8087969 & 18:48683589 & $\mathrm{G} / \mathrm{T}$ & 0.45 & 0.058 & 0.010 & $1.41 \mathrm{E}-08$ & 0.46 & $<0.001$ & 0.002 & $9.20 \mathrm{E}-01$ & 1.65E-03 \\
\hline rs55818311 & 19:2341047 & $\mathrm{C} / \mathrm{T}$ & 0.31 & 0.070 & 0.011 & $4.18 \mathrm{E}-10$ & 0.32 & 0.001 & 0.002 & 4.97E-01 & 2.06E-03 \\
\hline rs77351827 & 20:6006041 & $\mathrm{T} / \mathrm{C}$ & 0.13 & 0.080 & 0.014 & 8.87E-09 & 0.12 & 0.001 & 0.002 & 7.28E-01 & 1.43E-03 \\
\hline rs2248244 & 21:38852361 & $A / G$ & 0.28 & 0.071 & 0.011 & $2.74 \mathrm{E}-11$ & 0.28 & $\underline{0.006}$ & 0.002 & 3.86E-04 & 2.07E-03 \\
\hline \multicolumn{12}{|c|}{ Outcome: Lifetime smoking index } \\
\hline \multirow{2}{*}{$\begin{array}{l}\text { rs35749011 } \\
\text { rs6658353 }\end{array}$} & $1: 155135036$ & $A / G$ & 0.02 & 0.607 & 0.034 & $1.72 \mathrm{E}-70$ & 0.01 & -0.005 & 0.006 & 4.10E-01 & 1.22E-02 \\
\hline & $1: 161469054$ & $\mathrm{C} / \mathrm{G}$ & 0.50 & 0.065 & 0.009 & $6.10 \mathrm{E}-12$ & \multicolumn{5}{|c|}{ Excluded for reverse MR } \\
\hline
\end{tabular}




\begin{tabular}{|c|c|c|c|c|c|c|c|c|c|c|c|}
\hline \multirow[b]{2}{*}{ SNP } & \multirow[b]{2}{*}{ Chr:Pos (GRCh37) } & \multirow[b]{2}{*}{ EA/BA } & \multicolumn{4}{|c|}{ PD (Nalls et al., 2019) } & \multicolumn{4}{|c|}{ Outcome } & \multirow[b]{2}{*}{$\mathbf{R}^{2}$} \\
\hline & & & EAF & Beta & SE & P-value & EAF & Beta & SE & P-value & \\
\hline rs11578699 & 1:171719769 & $\mathrm{C} / \mathrm{T}$ & 0.81 & 0.070 & 0.012 & 4.47E-09 & 0.80 & -0.001 & 0.002 & 6.90E-01 & $1.56 \mathrm{E}-03$ \\
\hline rs823118 & $1: 205723572$ & $\mathrm{~T} / \mathrm{C}$ & 0.57 & 0.107 & 0.009 & $1.11 \mathrm{E}-29$ & 0.55 & $\underline{0.004}$ & 0.001 & 6.50E-03 & $5.58 \mathrm{E}-03$ \\
\hline rs4653767 & $1: 226916078$ & $\mathrm{~T} / \mathrm{C}$ & 0.72 & 0.083 & 0.010 & $1.38 \mathrm{E}-15$ & 0.72 & $\overline{-0.001}$ & 0.002 & 3.60E-01 & 2.80E-03 \\
\hline rs10797576 & $1: 232664611$ & $T / C$ & 0.14 & 0.111 & 0.013 & $6.84 \mathrm{E}-17$ & 0.12 & 0.006 & 0.002 & 8.50E-03 & 2.99E-03 \\
\hline rs76116224 & $2: 18147848$ & $A / T$ & 0.90 & 0.110 & 0.019 & $1.27 \mathrm{E}-08$ & 0.90 & $<0.001$ & 0.002 & 8.60E-01 & 2.11E-03 \\
\hline rs2042477 & $2: 96000943$ & $T / A$ & 0.76 & 0.066 & 0.012 & $1.38 \mathrm{E}-08$ & 0.74 & -0.001 & 0.002 & 7.10E-01 & $1.58 \mathrm{E}-03$ \\
\hline rs11683001 & 2:102396963 & $A / T$ & 0.34 & 0.070 & 0.010 & 8.04E-13 & 0.34 & $\underline{0.004}$ & 0.001 & 5.00E-03 & $2.22 \mathrm{E}-03$ \\
\hline rs57891859 & $2: 135464616$ & $A / G$ & 0.72 & 0.081 & 0.011 & $4.55 \mathrm{E}-14$ & 0.75 & $\overline{<0.001}$ & 0.002 & 7.80E-01 & 2.63E-03 \\
\hline rs1474055 & $2: 169110394$ & $\mathrm{~T} / \mathrm{C}$ & 0.13 & 0.180 & 0.014 & 2.54E-39 & 0.12 & 0.004 & 0.002 & $6.00 \mathrm{E}-02$ & 7.35E-03 \\
\hline rs73038319 & 3:18361759 & $\mathrm{C} / \mathrm{A}$ & 0.04 & 0.169 & 0.024 & 5.94E-13 & 0.04 & 0.005 & 0.004 & $1.90 \mathrm{E}-01$ & 2.24E-03 \\
\hline rs6808178 & $3: 28705690$ & $\mathrm{~T} / \mathrm{C}$ & 0.38 & 0.066 & 0.010 & 8.09E-12 & 0.38 & 0.001 & 0.001 & 6.30E-01 & 2.04E-03 \\
\hline rs12497850 & $3: 48748989$ & $T / G$ & 0.65 & 0.064 & 0.010 & $1.36 \mathrm{E}-10$ & 0.65 & -0.006 & 0.001 & $1.50 \mathrm{E}-05$ & $1.85 \mathrm{E}-03$ \\
\hline rs55961674 & 3:122196892 & $T / C$ & 0.17 & 0.086 & 0.013 & $9.98 \mathrm{E}-12$ & 0.15 & $\overline{0.002}$ & 0.002 & 2.40E-01 & $2.11 \mathrm{E}-03$ \\
\hline rs11707416 & $3: 151108965$ & $T / A$ & 0.63 & 0.063 & 0.010 & $1.13 \mathrm{E}-10$ & 0.63 & $\underline{0.003}$ & 0.001 & 2.20E-02 & 1.83E-03 \\
\hline rs10513789 & 3:182760073 & $T / G$ & 0.81 & 0.148 & 0.012 & $1.22 \mathrm{E}-34$ & 0.81 & 0.003 & 0.002 & 4.80E-02 & $6.75 \mathrm{E}-03$ \\
\hline rs34311866 & 4:951947 & $\mathrm{C} / \mathrm{T}$ & 0.19 & 0.213 & 0.012 & $9.98 \mathrm{E}-70$ & 0.18 & $<0.001$ & 0.002 & 8.90E-01 & 1.41E-02 \\
\hline rs4698412 & $4: 15737348$ & $A / G$ & 0.55 & 0.104 & 0.009 & 2.06E-28 & 0.55 & -0.001 & 0.001 & 3.10E-01 & 5.30E-03 \\
\hline rs6854006 & $4: 77198054$ & $\mathrm{C} / \mathrm{T}$ & 0.64 & 0.091 & 0.010 & $5.82 \mathrm{E}-21$ & 0.62 & -0.004 & 0.001 & $6.00 \mathrm{E}-03$ & 3.85E-03 \\
\hline rs356182 & $4: 90626111$ & $G / A$ & 0.37 & 0.277 & 0.011 & $3.89 E-154$ & 0.34 & -0.001 & 0.001 & $6.20 \mathrm{E}-01$ & 3.60E-02 \\
\hline rs13117519 & $4: 114369065$ & $\mathrm{~T} / \mathrm{C}$ & 0.17 & 0.088 & 0.012 & $9.82 \mathrm{E}-13$ & 0.17 & 0.001 & 0.002 & 5.40E-01 & $2.20 \mathrm{E}-03$ \\
\hline rs62333164 & $4: 170583157$ & $\mathrm{G} / \mathrm{A}$ & 0.67 & 0.064 & 0.010 & $2.00 \mathrm{E}-10$ & 0.67 & -0.001 & 0.001 & 4.00E-01 & 1.79E-03 \\
\hline rs1867598 & 5:60137959 & $\mathrm{G} / \mathrm{A}$ & 0.10 & 0.155 & 0.016 & $2.52 E-23$ & 0.08 & 0.002 & 0.003 & $5.60 \mathrm{E}-01$ & 4.27E-03 \\
\hline rs26431 & $5: 102365794$ & $\mathrm{C} / \mathrm{G}$ & 0.70 & 0.062 & 0.010 & 1.57E-09 & 0.69 & -0.002 & 0.002 & $2.60 \mathrm{E}-01$ & $1.61 \mathrm{E}-03$ \\
\hline rs11950533 & 5:134199105 & $\mathrm{C} / \mathrm{A}$ & 0.90 & 0.092 & 0.016 & 7.16E-09 & 0.90 & -0.003 & 0.002 & $1.50 \mathrm{E}-01$ & $1.54 \mathrm{E}-03$ \\
\hline rs112485576 & 6:32578772 & $\mathrm{C} / \mathrm{A}$ & 0.84 & 0.168 & 0.015 & $6.96 \mathrm{E}-28$ & 0.81 & -0.002 & 0.002 & $3.00 \mathrm{E}-01$ & 7.66E-03 \\
\hline rs12528068 & 6:72487762 & $\mathrm{T} / \mathrm{C}$ & 0.28 & 0.066 & 0.010 & $1.63 \mathrm{E}-10$ & 0.28 & -0.001 & 0.002 & $6.20 \mathrm{E}-01$ & 1.76E-03 \\
\hline rs997368 & 6:112243291 & $A / G$ & 0.80 & 0.071 & 0.012 & 1.84E-09 & 0.82 & 0.002 & 0.002 & 2.30E-01 & 1.60E-03 \\
\hline rs75859381 & 6:133210361 & $\mathrm{C} / \mathrm{T}$ & 0.03 & 0.221 & 0.034 & $1.04 \mathrm{E}-10$ & 0.03 & -0.002 & 0.004 & $6.90 \mathrm{E}-01$ & 3.08E-03 \\
\hline rs199351 & 7:23300049 & $\mathrm{A} / \mathrm{C}$ & 0.59 & 0.102 & 0.010 & $5.25 E-26$ & 0.59 & -0.001 & 0.001 & 3.70E-01 & 4.98E-03 \\
\hline rs76949143 & $7: 66009851$ & T/A & 0.95 & 0.143 & 0.025 & $1.43 \mathrm{E}-08$ & 0.95 & 0.005 & 0.003 & 1.30E-01 & 1.97E-03 \\
\hline rs1293298 & $8: 11712443$ & $A / C$ & 0.74 & 0.093 & 0.011 & $3.99 \mathrm{E}-16$ & 0.74 & 0.005 & 0.002 & $2.20 \mathrm{E}-03$ & $3.29 \mathrm{E}-03$ \\
\hline rs2280104 & $8: 22525980$ & $\mathrm{~T} / \mathrm{C}$ & 0.36 & 0.056 & 0.010 & $1.16 \mathrm{E}-08$ & 0.35 & -0.004 & 0.001 & 1.10E-02 & 1.43E-03 \\
\hline rs2086641 & 8:130901909 & $\mathrm{C} / \mathrm{T}$ & 0.28 & 0.060 & 0.011 & $1.81 \mathrm{E}-08$ & 0.26 & -0.002 & 0.002 & 1.70E-01 & 1.47E-03 \\
\hline rs13294100 & 9:17579690 & $\mathrm{G} / \mathrm{T}$ & 0.66 & 0.086 & 0.010 & $8.72 \mathrm{E}-18$ & 0.65 & $\underline{0.005}$ & 0.001 & 2.00E-03 & 3.32E-03 \\
\hline rs6476434 & 9:34046391 & $\mathrm{C} / \mathrm{T}$ & 0.27 & 0.062 & 0.011 & 6.58E-09 & 0.27 & $\overline{0.001}$ & 0.002 & $6.50 \mathrm{E}-01$ & $1.48 \mathrm{E}-03$ \\
\hline rs896435 & $10: 15557406$ & $\mathrm{~T} / \mathrm{C}$ & 0.69 & 0.074 & 0.010 & $3.41 \mathrm{E}-13$ & 0.68 & $<0.001$ & 0.001 & 8.30E-01 & 2.31E-03 \\
\hline rs10748818 & 10:104015279 & $\mathrm{G} / \mathrm{A}$ & 0.15 & 0.079 & 0.013 & 1.05E-09 & 0.15 & $\underline{-0.006}$ & 0.002 & 3.40E-03 & 1.58E-03 \\
\hline rs117896735 & 10:121536327 & $A / G$ & 0.02 & 0.435 & 0.039 & 2.36E-28 & 0.02 & -0.007 & 0.005 & 2.20E-01 & $6.19 \mathrm{E}-03$ \\
\hline rs7938782 & 11:10558777 & $A / G$ & 0.88 & 0.087 & 0.015 & 2.12E-09 & 0.88 & $<0.001$ & 0.002 & 8.50E-01 & 1.63E-03 \\
\hline rs12283611 & 11:83487277 & $\mathrm{C} / \mathrm{A}$ & 0.59 & 0.064 & 0.010 & $2.61 \mathrm{E}-10$ & 0.59 & -0.001 & 0.001 & 4.40E-01 & 2.02E-03 \\
\hline rs3802920 & 11:133787001 & $\mathrm{T} / \mathrm{G}$ & 0.21 & 0.107 & 0.012 & $6.26 \mathrm{E}-20$ & 0.20 & -0.002 & 0.002 & $2.90 \mathrm{E}-01$ & 3.76E-03 \\
\hline rs76904798 & 12:40614434 & $\mathrm{T} / \mathrm{C}$ & 0.14 & 0.144 & 0.013 & $1.52 \mathrm{E}-28$ & 0.14 & -0.002 & 0.002 & 2.70E-01 & $5.12 \mathrm{E}-03$ \\
\hline rs7134559 & 12:46419086 & $\mathrm{C} / \mathrm{T}$ & 0.60 & 0.054 & 0.010 & 3.96E-08 & 0.60 & $<0.001$ & 0.001 & 8.10E-01 & 1.40E-03 \\
\hline rs10847864 & 12:123326598 & $\mathrm{T} / \mathrm{G}$ & 0.36 & 0.148 & 0.012 & 1.47E-37 & 0.35 & -0.002 & 0.001 & 2.10E-01 & 1.01E-02 \\
\hline rs9568188 & 13:49927732 & $\mathrm{T} / \mathrm{C}$ & 0.74 & 0.062 & 0.011 & 1.15E-08 & 0.73 & -0.001 & 0.002 & 5.80E-01 & 1.47E-03 \\
\hline rs4771268 & 13:97865021 & $\mathrm{T} / \mathrm{C}$ & 0.23 & 0.068 & 0.011 & 1.45E-09 & 0.22 & 0.001 & 0.002 & 5.90E-01 & 1.61E-03 \\
\hline rs12147950 & $14: 37989270$ & $\mathrm{C} / \mathrm{T}$ & 0.56 & 0.053 & 0.010 & 3.54E-08 & 0.57 & 0.002 & 0.001 & $1.90 \mathrm{E}-01$ & 1.38E-03 \\
\hline
\end{tabular}




\begin{tabular}{|c|c|c|c|c|c|c|c|c|c|c|c|}
\hline \multirow[b]{2}{*}{ SNP } & \multirow[b]{2}{*}{ Chr:Pos (GRCh37) } & \multirow[b]{2}{*}{ EA/BA } & \multicolumn{4}{|c|}{ PD (Nalls et al., 2019) } & \multicolumn{4}{|c|}{ Outcome } & \multirow[b]{2}{*}{$\mathbf{R}^{2}$} \\
\hline & & & EAF & Beta & SE & P-value & EAF & Beta & SE & P-value & \\
\hline rs11158026 & $14: 55348869$ & $\mathrm{C} / \mathrm{T}$ & 0.68 & 0.084 & 0.010 & $1.66 \mathrm{E}-16$ & 0.66 & -0.002 & 0.001 & $2.50 \mathrm{E}-01$ & $3.11 \mathrm{E}-03$ \\
\hline rs3742785 & $14: 75373034$ & $\mathrm{~A} / \mathrm{C}$ & 0.79 & 0.071 & 0.012 & $1.92 \mathrm{E}-09$ & 0.78 & -0.002 & 0.002 & $1.60 \mathrm{E}-01$ & $1.68 \mathrm{E}-03$ \\
\hline rs979812 & $14: 88464264$ & $T / G$ & 0.44 & 0.061 & 0.009 & $6.19 \mathrm{E}-11$ & 0.42 & $<0.001$ & 0.001 & 8.90E-01 & $1.84 \mathrm{E}-03$ \\
\hline rs2251086 & 15:61997385 & $\mathrm{C} / \mathrm{T}$ & 0.86 & 0.119 & 0.014 & $6.08 \mathrm{E}-18$ & 0.86 & -0.003 & 0.002 & 7.80E-02 & $3.42 \mathrm{E}-03$ \\
\hline rs6497339 & $16: 19277493$ & $A / T$ & 0.45 & 0.063 & 0.010 & $2.76 \mathrm{E}-11$ & \multicolumn{5}{|c|}{ Excluded for reverse MR } \\
\hline rs11150601 & 16:30977799 & $A / G$ & 0.64 & 0.091 & 0.010 & $5.12 \mathrm{E}-20$ & 0.63 & $\underline{-0.004}$ & 0.001 & 1.30E-02 & 3.77E-03 \\
\hline rs3104783 & 16:52636242 & $A / C$ & 0.43 & 0.067 & 0.009 & $1.29 \mathrm{E}-12$ & 0.42 & 0.001 & 0.001 & 3.10E-01 & 2.19E-03 \\
\hline rs12600861 & $17: 7355621$ & $\mathrm{C} / \mathrm{A}$ & 0.35 & 0.056 & 0.010 & $1.01 \mathrm{E}-08$ & 0.36 & -0.005 & 0.001 & $1.40 \mathrm{E}-03$ & 1.46E-03 \\
\hline rs850738 & $17: 42434630$ & $G / A$ & 0.39 & 0.071 & 0.011 & $1.29 \mathrm{E}-11$ & 0.39 & 0.002 & 0.001 & 2.00E-01 & 2.41E-03 \\
\hline rs62053943 & $17: 43744203$ & $\mathrm{C} / \mathrm{T}$ & 0.84 & 0.270 & 0.016 & $3.58 \mathrm{E}-68$ & 0.85 & $\underline{0.006}$ & 0.002 & 8.50E-04 & 1.91E-02 \\
\hline rs61169879 & 17:59917366 & $\mathrm{T} / \mathrm{C}$ & 0.16 & 0.082 & 0.013 & $9.28 \mathrm{E}-10$ & 0.16 & -0.001 & 0.002 & 7.00E-01 & 1.84E-03 \\
\hline rs666463 & $17: 76425480$ & $A / T$ & 0.83 & 0.076 & 0.013 & 3.20E-09 & 0.83 & 0.002 & 0.002 & 2.10E-01 & 1.61E-03 \\
\hline rs1941685 & $18: 31304318$ & $\mathrm{~T} / \mathrm{G}$ & 0.50 & 0.053 & 0.009 & $1.69 \mathrm{E}-08$ & 0.50 & -0.002 & 0.001 & $1.90 \mathrm{E}-01$ & $1.41 \mathrm{E}-03$ \\
\hline rs12456492 & $18: 40673380$ & $G / A$ & 0.32 & 0.098 & 0.010 & $3.80 \mathrm{E}-23$ & 0.31 & $=0.003$ & 0.001 & 2.80E-02 & 4.19E-03 \\
\hline rs8087969 & 18:48683589 & $\mathrm{G} / \mathrm{T}$ & 0.45 & 0.058 & 0.010 & $1.41 \mathrm{E}-08$ & 0.46 & -0.001 & 0.001 & 4.40E-01 & 1.65E-03 \\
\hline rs55818311 & 19:2341047 & $\mathrm{C} / \mathrm{T}$ & 0.31 & 0.070 & 0.011 & $4.18 \mathrm{E}-10$ & 0.32 & -0.001 & 0.002 & 4.00E-01 & 2.06E-03 \\
\hline rs77351827 & 20:6006041 & $\mathrm{T} / \mathrm{C}$ & 0.13 & 0.080 & 0.014 & 8.87E-09 & 0.12 & $\underline{0.005}$ & 0.002 & 2.50E-02 & 1.43E-03 \\
\hline rs2248244 & 21:38852361 & $A / G$ & 0.28 & 0.071 & 0.011 & $2.74 \mathrm{E}-11$ & 0.28 & -0.001 & 0.002 & 3.60E-01 & 2.07E-03 \\
\hline \multicolumn{12}{|c|}{ Outcome: Smoking initiation } \\
\hline rs35749011 & $1: 155135036$ & $A / G$ & 0.02 & 0.607 & 0.034 & $1.72 \mathrm{E}-70$ & 0.01 & 0.011 & 0.015 & 4.50E-01 & 1.22E-02 \\
\hline rs6658353 & $1: 161469054$ & $\mathrm{C} / \mathrm{G}$ & 0.50 & 0.065 & 0.009 & $6.10 \mathrm{E}-12$ & \multicolumn{5}{|c|}{ Excluded for reverse MR } \\
\hline rs11578699 & $1: 171719769$ & $\mathrm{C} / \mathrm{T}$ & 0.81 & 0.070 & 0.012 & 4.47E-09 & 0.80 & 0.006 & 0.005 & $1.70 \mathrm{E}-01$ & $1.56 \mathrm{E}-03$ \\
\hline rs823118 & 1:205723572 & $\mathrm{T} / \mathrm{C}$ & 0.57 & 0.107 & 0.009 & $1.11 \mathrm{E}-29$ & 0.55 & $\underline{0.011}$ & 0.004 & 2.75E-03 & $5.58 \mathrm{E}-03$ \\
\hline rs4653767 & $1: 226916078$ & $\mathrm{~T} / \mathrm{C}$ & 0.72 & 0.083 & 0.010 & $1.38 \mathrm{E}-15$ & 0.70 & 0.002 & 0.004 & 5.68E-01 & 2.80E-03 \\
\hline rs10797576 & $1: 232664611$ & $\mathrm{~T} / \mathrm{C}$ & 0.14 & 0.111 & 0.013 & $6.84 \mathrm{E}-17$ & 0.14 & 0.009 & 0.005 & $9.08 \mathrm{E}-02$ & 2.99E-03 \\
\hline rs76116224 & 2:18147848 & $A / T$ & 0.90 & 0.110 & 0.019 & $1.27 \mathrm{E}-08$ & 0.91 & 0.006 & 0.006 & 3.06E-01 & $2.11 \mathrm{E}-03$ \\
\hline rs2042477 & $2: 96000943$ & $T / A$ & 0.76 & 0.066 & 0.012 & 1.38E-08 & 0.75 & 0.002 & 0.004 & 5.47E-01 & 1.58E-03 \\
\hline rs11683001 & $2: 102396963$ & $A / T$ & 0.34 & 0.070 & 0.010 & 8.04E-13 & 0.33 & 0.007 & 0.004 & 5.86E-02 & 2.22E-03 \\
\hline rs57891859 & 2:135464616 & $A / G$ & 0.72 & 0.081 & 0.011 & $4.55 \mathrm{E}-14$ & 0.69 & -0.003 & 0.004 & 5.19E-01 & 2.63E-03 \\
\hline rs1474055 & 2:169110394 & $\mathrm{T} / \mathrm{C}$ & 0.13 & 0.180 & 0.014 & 2.54E-39 & 0.13 & $\underline{0.013}$ & 0.006 & 1.86E-02 & 7.35E-03 \\
\hline rs73038319 & 3:18361759 & $\mathrm{C} / \mathrm{A}$ & 0.04 & 0.169 & 0.024 & $5.94 \mathrm{E}-13$ & 0.04 & 0.014 & 0.009 & 1.15E-01 & 2.24E-03 \\
\hline rs6808178 & $3: 28705690$ & $\mathrm{~T} / \mathrm{C}$ & 0.38 & 0.066 & 0.010 & 8.09E-12 & 0.36 & -0.004 & 0.004 & 2.59E-01 & 2.04E-03 \\
\hline rs12497850 & 3:48748989 & $\mathrm{T} / \mathrm{G}$ & 0.65 & 0.064 & 0.010 & $1.36 \mathrm{E}-10$ & 0.64 & $\underline{-0.012}$ & 0.004 & 1.76E-03 & 1.85E-03 \\
\hline rs55961674 & 3:122196892 & $T / C$ & 0.17 & 0.086 & 0.013 & $9.98 \mathrm{E}-12$ & 0.16 & $\overline{0.003}$ & 0.005 & 5.79E-01 & $2.11 \mathrm{E}-03$ \\
\hline rs11707416 & $3: 151108965$ & $\mathrm{~T} / \mathrm{A}$ & 0.63 & 0.063 & 0.010 & $1.13 \mathrm{E}-10$ & 0.64 & $<0.001$ & 0.004 & $9.17 \mathrm{E}-01$ & 1.83E-03 \\
\hline rs10513789 & $3: 182760073$ & $T / G$ & 0.81 & 0.148 & 0.012 & $1.22 \mathrm{E}-34$ & 0.79 & 0.003 & 0.004 & 5.13E-01 & $6.75 \mathrm{E}-03$ \\
\hline rs34311866 & $4: 951947$ & $\mathrm{C} / \mathrm{T}$ & 0.19 & 0.213 & 0.012 & $9.98 \mathrm{E}-70$ & 0.18 & 0.002 & 0.005 & $6.04 \mathrm{E}-01$ & 1.41E-02 \\
\hline rs4698412 & $4: 15737348$ & $A / G$ & 0.55 & 0.104 & 0.009 & 2.06E-28 & 0.54 & 0.002 & 0.004 & $6.16 \mathrm{E}-01$ & $5.30 \mathrm{E}-03$ \\
\hline rs6854006 & 4:77198054 & $\mathrm{C} / \mathrm{T}$ & 0.64 & 0.091 & 0.010 & $5.82 E-21$ & 0.64 & -0.007 & 0.004 & 6.93E-02 & 3.85E-03 \\
\hline rs356182 & 4:90626111 & $\mathrm{G} / \mathrm{A}$ & 0.37 & 0.277 & 0.011 & 3.89E-154 & 0.35 & $<0.001$ & 0.004 & 9.27E-01 & 3.60E-02 \\
\hline rs13117519 & 4:114369065 & $\mathrm{T} / \mathrm{C}$ & 0.17 & 0.088 & 0.012 & $9.82 \mathrm{E}-13$ & 0.16 & -0.002 & 0.005 & $6.68 \mathrm{E}-01$ & $2.20 \mathrm{E}-03$ \\
\hline rs62333164 & $4: 170583157$ & $\mathrm{G} / \mathrm{A}$ & 0.67 & 0.064 & 0.010 & $2.00 \mathrm{E}-10$ & 0.67 & 0.006 & 0.004 & 1.22E-01 & 1.79E-03 \\
\hline rs1867598 & 5:60137959 & $\mathrm{G} / \mathrm{A}$ & 0.10 & 0.155 & 0.016 & $2.52 \mathrm{E}-23$ & 0.09 & -0.005 & 0.006 & 4.08E-01 & 4.27E-03 \\
\hline rs26431 & $5: 102365794$ & $\mathrm{C} / \mathrm{G}$ & 0.70 & 0.062 & 0.010 & 1.57E-09 & 0.70 & -0.006 & 0.004 & 1.36E-01 & $1.61 \mathrm{E}-03$ \\
\hline rs11950533 & 5:134199105 & $\mathrm{C} / \mathrm{A}$ & 0.90 & 0.092 & 0.016 & 7.16E-09 & 0.88 & -0.002 & 0.006 & 7.02E-01 & $1.54 \mathrm{E}-03$ \\
\hline rs12528068 & 6:72487762 & $\mathrm{T} / \mathrm{C}$ & 0.28 & 0.066 & 0.010 & $1.63 \mathrm{E}-10$ & 0.28 & 0.003 & 0.004 & 4.49E-01 & 1.76E-03 \\
\hline rs997368 & 6:112243291 & $A / G$ & 0.80 & 0.071 & 0.012 & 1.84E-09 & 0.79 & 0.003 & 0.005 & 4.65E-01 & 1.60E-03 \\
\hline
\end{tabular}




\begin{tabular}{|c|c|c|c|c|c|c|c|c|c|c|c|}
\hline \multirow[b]{2}{*}{ SNP } & \multirow[b]{2}{*}{ Chr:Pos (GRCh37) } & \multirow[b]{2}{*}{ EA/BA } & \multicolumn{4}{|c|}{ PD (Nalls et al., 2019) } & \multicolumn{4}{|c|}{ Outcome } & \multirow[b]{2}{*}{$\mathbf{R}^{2}$} \\
\hline & & & EAF & Beta & SE & P-value & EAF & Beta & SE & P-value & \\
\hline rs75859381 & $6: 133210361$ & $\mathrm{C} / \mathrm{T}$ & 0.03 & 0.221 & 0.034 & $1.04 \mathrm{E}-10$ & 0.03 & 0.008 & 0.011 & 4.57E-01 & $3.08 \mathrm{E}-03$ \\
\hline rs199351 & $7: 23300049$ & $\mathrm{~A} / \mathrm{C}$ & 0.59 & 0.102 & 0.010 & $5.25 E-26$ & 0.57 & -0.003 & 0.004 & 4.13E-01 & 4.98E-03 \\
\hline rs76949143 & $7: 66009851$ & $\mathrm{~T} / \mathrm{A}$ & 0.95 & 0.143 & 0.025 & 1.43E-08 & 0.94 & 0.009 & 0.008 & 2.58E-01 & 1.97E-03 \\
\hline rs1293298 & $8: 11712443$ & $A / C$ & 0.74 & 0.093 & 0.011 & $3.99 \mathrm{E}-16$ & 0.76 & 0.004 & 0.004 & $3.41 \mathrm{E}-01$ & $3.29 \mathrm{E}-03$ \\
\hline rs2280104 & $8: 22525980$ & $\mathrm{~T} / \mathrm{C}$ & 0.36 & 0.056 & 0.010 & $1.16 \mathrm{E}-08$ & 0.35 & -0.006 & 0.004 & $1.04 \mathrm{E}-01$ & 1.43E-03 \\
\hline rs2086641 & 8:130901909 & $\mathrm{C} / \mathrm{T}$ & 0.28 & 0.060 & 0.011 & $1.81 \mathrm{E}-08$ & 0.26 & -0.005 & 0.004 & 2.01E-01 & $1.47 \mathrm{E}-03$ \\
\hline rs13294100 & 9:17579690 & $\mathrm{G} / \mathrm{T}$ & 0.66 & 0.086 & 0.010 & $8.72 \mathrm{E}-18$ & 0.63 & $\underline{0.009}$ & 0.004 & 1.65E-02 & 3.32E-03 \\
\hline rs6476434 & $9: 34046391$ & $\mathrm{C} / \mathrm{T}$ & 0.27 & 0.062 & 0.011 & $6.58 \mathrm{E}-09$ & 0.26 & $\overline{-0.005}$ & 0.004 & $1.95 \mathrm{E}-01$ & $1.48 \mathrm{E}-03$ \\
\hline rs896435 & $10: 15557406$ & $\mathrm{~T} / \mathrm{C}$ & 0.69 & 0.074 & 0.010 & $3.41 \mathrm{E}-13$ & 0.67 & 0.006 & 0.004 & $1.41 \mathrm{E}-01$ & 2.31E-03 \\
\hline rs10748818 & 10:104015279 & $\mathrm{G} / \mathrm{A}$ & 0.15 & 0.079 & 0.013 & $1.05 \mathrm{E}-09$ & 0.14 & -0.011 & 0.005 & 2.47E-02 & $1.58 \mathrm{E}-03$ \\
\hline rs117896735 & $10: 121536327$ & $A / G$ & 0.02 & 0.435 & 0.039 & $2.36 \mathrm{E}-28$ & 0.01 & 0.007 & 0.013 & $5.92 \mathrm{E}-01$ & 6.19E-03 \\
\hline rs7938782 & $11: 10558777$ & $A / G$ & 0.88 & 0.087 & 0.015 & 2.12E-09 & 0.86 & $\underline{0.015}$ & 0.006 & 8.85E-03 & 1.63E-03 \\
\hline rs12283611 & $11: 83487277$ & $\mathrm{C} / \mathrm{A}$ & 0.59 & 0.064 & 0.010 & $2.61 \mathrm{E}-10$ & 0.57 & $-\overline{0.001}$ & 0.004 & $7.58 \mathrm{E}-01$ & $2.02 \mathrm{E}-03$ \\
\hline rs3802920 & $11: 133787001$ & $T / G$ & 0.21 & 0.107 & 0.012 & $6.26 \mathrm{E}-20$ & 0.20 & -0.008 & 0.005 & $6.51 \mathrm{E}-02$ & $3.76 \mathrm{E}-03$ \\
\hline rs76904798 & $12: 40614434$ & $\mathrm{~T} / \mathrm{C}$ & 0.14 & 0.144 & 0.013 & $1.52 \mathrm{E}-28$ & 0.13 & -0.003 & 0.005 & 5.94E-01 & $5.12 \mathrm{E}-03$ \\
\hline rs7134559 & 12:46419086 & $\mathrm{C} / \mathrm{T}$ & 0.60 & 0.054 & 0.010 & 3.96E-08 & 0.61 & $\underline{0.009}$ & 0.004 & 9.77E-03 & 1.40E-03 \\
\hline rs10847864 & 12:123326598 & $\mathrm{T} / \mathrm{G}$ & 0.36 & 0.148 & 0.012 & 1.47E-37 & 0.35 & $<0.001$ & 0.004 & $9.56 \mathrm{E}-01$ & 1.01E-02 \\
\hline rs9568188 & 13:49927732 & $\mathrm{T} / \mathrm{C}$ & 0.74 & 0.062 & 0.011 & $1.15 \mathrm{E}-08$ & 0.72 & -0.003 & 0.004 & 4.18E-01 & 1.47E-03 \\
\hline rs4771268 & $13: 97865021$ & $\mathrm{~T} / \mathrm{C}$ & 0.23 & 0.068 & 0.011 & $1.45 \mathrm{E}-09$ & 0.24 & -0.003 & 0.004 & $5.51 \mathrm{E}-01$ & $1.61 \mathrm{E}-03$ \\
\hline rs12147950 & $14: 37989270$ & $\mathrm{C} / \mathrm{T}$ & 0.56 & 0.053 & 0.010 & $3.54 \mathrm{E}-08$ & 0.56 & 0.007 & 0.004 & 5.86E-02 & 1.38E-03 \\
\hline rs11158026 & 14:55348869 & $\mathrm{C} / \mathrm{T}$ & 0.68 & 0.084 & 0.010 & $1.66 \mathrm{E}-16$ & 0.66 & -0.001 & 0.004 & 8.68E-01 & $3.11 \mathrm{E}-03$ \\
\hline rs3742785 & $14: 75373034$ & $A / C$ & 0.79 & 0.071 & 0.012 & 1.92E-09 & 0.77 & -0.001 & 0.004 & $9.01 \mathrm{E}-01$ & $1.68 \mathrm{E}-03$ \\
\hline rs979812 & $14: 88464264$ & $T / G$ & 0.44 & 0.061 & 0.009 & $6.19 \mathrm{E}-11$ & 0.44 & $\underline{0.008}$ & 0.004 & 2.96E-02 & $1.84 \mathrm{E}-03$ \\
\hline rs2251086 & 15:61997385 & $\mathrm{C} / \mathrm{T}$ & 0.86 & 0.119 & 0.014 & $6.08 \mathrm{E}-18$ & 0.84 & $<0.001$ & 0.005 & $9.53 \mathrm{E}-01$ & $3.42 \mathrm{E}-03$ \\
\hline rs6497339 & $16: 19277493$ & $\mathrm{~A} / \mathrm{T}$ & 0.45 & 0.063 & 0.010 & $2.76 \mathrm{E}-11$ & & & uded fo & erse MR & \\
\hline rs11150601 & 16:30977799 & $A / G$ & 0.64 & 0.091 & 0.010 & $5.12 \mathrm{E}-20$ & 0.63 & -0.005 & 0.004 & $1.72 \mathrm{E}-01$ & 3.77E-03 \\
\hline rs3104783 & $16: 52636242$ & $A / C$ & 0.43 & 0.067 & 0.009 & $1.29 \mathrm{E}-12$ & 0.44 & $\underline{-0.008}$ & 0.004 & 3.35E-02 & 2.19E-03 \\
\hline rs12600861 & 17:7355621 & $\mathrm{C} / \mathrm{A}$ & 0.35 & 0.056 & 0.010 & $1.01 \mathrm{E}-08$ & 0.35 & -0.009 & 0.004 & 1.37E-02 & 1.46E-03 \\
\hline rs850738 & $17: 42434630$ & $\mathrm{G} / \mathrm{A}$ & 0.39 & 0.071 & 0.011 & $1.29 \mathrm{E}-11$ & 0.39 & 0.006 & 0.004 & $9.01 \mathrm{E}-02$ & $2.41 \mathrm{E}-03$ \\
\hline rs62053943 & $17: 43744203$ & $\mathrm{C} / \mathrm{T}$ & 0.84 & 0.270 & 0.016 & $3.58 E-68$ & 0.86 & 0.008 & 0.005 & $1.23 \mathrm{E}-01$ & $1.91 \mathrm{E}-02$ \\
\hline rs61169879 & 17:59917366 & $\mathrm{T} / \mathrm{C}$ & 0.16 & 0.082 & 0.013 & $9.28 \mathrm{E}-10$ & 0.17 & 0.001 & 0.005 & 7.83E-01 & 1.84E-03 \\
\hline rs666463 & $17: 76425480$ & $\mathrm{~A} / \mathrm{T}$ & 0.83 & 0.076 & 0.013 & 3.20E-09 & 0.84 & -0.001 & 0.005 & 8.93E-01 & $1.61 \mathrm{E}-03$ \\
\hline rs1941685 & $18: 31304318$ & $T / G$ & 0.50 & 0.053 & 0.009 & 1.69E-08 & 0.52 & -0.002 & 0.004 & $6.01 \mathrm{E}-01$ & $1.41 \mathrm{E}-03$ \\
\hline rs12456492 & $18: 40673380$ & $\mathrm{G} / \mathrm{A}$ & 0.32 & 0.098 & 0.010 & $3.80 \mathrm{E}-23$ & 0.32 & -0.006 & 0.004 & 1.16E-01 & $4.19 \mathrm{E}-03$ \\
\hline rs8087969 & 18:48683589 & $\mathrm{G} / \mathrm{T}$ & 0.45 & 0.058 & 0.010 & 1.41E-08 & 0.44 & 0.002 & 0.004 & 5.22E-01 & 1.65E-03 \\
\hline rs55818311 & 19:2341047 & $\mathrm{C} / \mathrm{T}$ & 0.31 & 0.070 & 0.011 & $4.18 \mathrm{E}-10$ & 0.33 & -0.004 & 0.004 & 2.87E-01 & 2.06E-03 \\
\hline rs77351827 & $20: 6006041$ & $\mathrm{~T} / \mathrm{C}$ & 0.13 & 0.080 & 0.014 & 8.87E-09 & 0.12 & 0.006 & 0.005 & 3.05E-01 & 1.43E-03 \\
\hline rs2248244 & $21: 38852361$ & $A / G$ & 0.28 & 0.071 & 0.011 & $2.74 \mathrm{E}-11$ & 0.28 & 0.004 & 0.004 & 2.79E-01 & 2.07E-03 \\
\hline
\end{tabular}

NA, not available; EA/BA, effect allele/base allele; EAF, effect allele frequency; SE, standard error.

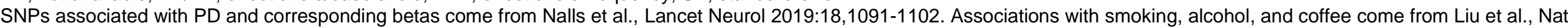
Genet 2019:51, 237-244; Zhong et al., Hum Mol Genet 2019:28, 2449-2457; and Wootton et al., Psychol Med 2019:50, $2435-2443$.

Bold coefficients and corresponding SE and $p$-values are significant at $p \leq 0.05$; those underlined with a solid line are negative and those underlined with a dashed line are positive.

$R^{2}$ is the proportion of the variance of the exposure explained by the genetic variant according to the formula: $2 \times$ Betaexposure $\times E A F_{\text {exposure }} \times\left(1-E A F_{\text {exposure }}\right)$. 


\section{Supplementary figure 1: Survival bias in Mendelian randomization studies of diseases in elderly populations.}

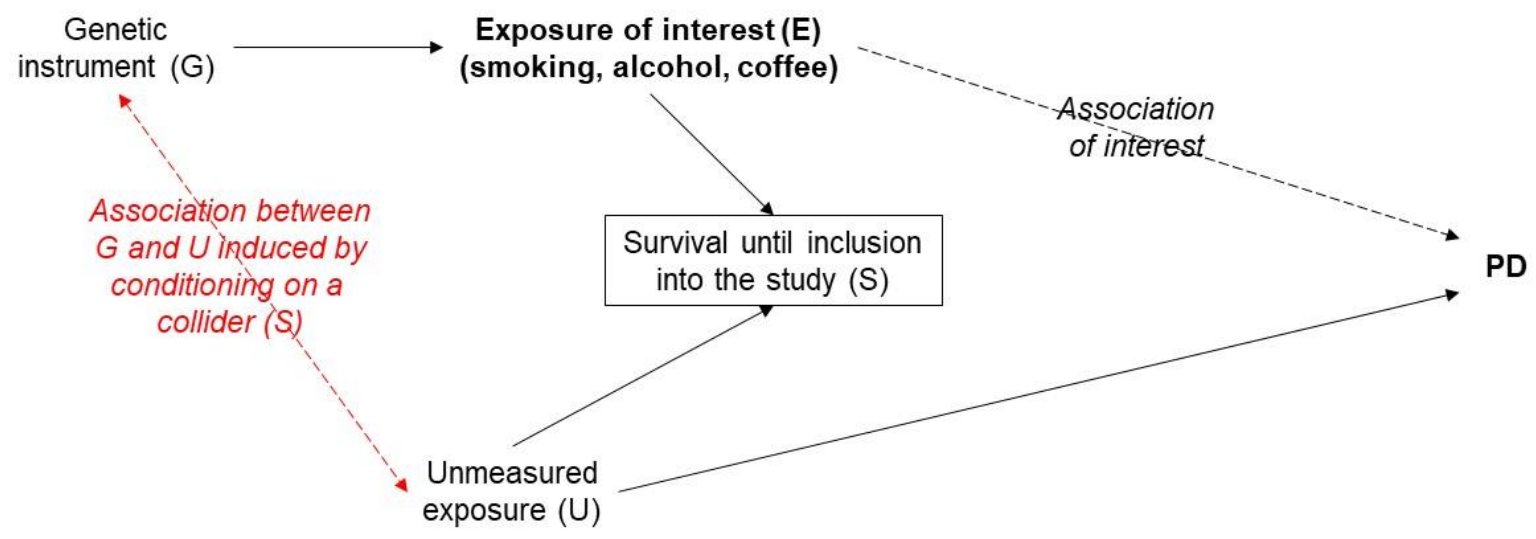

If both the exposure of interest (E) and an unmeasured exposure $(U)$ influence survival $(S)$, conditioning on survival up to the age at inclusion into the study creates an association between $U$ and $G$ (and $E$ ) (red dashed double arrow) because $S$ is a collider. If $U$ is not taken into account in the analysis, the association of $\mathrm{G}$ (and $\mathrm{E}$ ) with PD is biased due to the association between $\mathrm{U}$ and $\mathrm{G}$. The bias is more important for exposures that have an important effect on survival, and if there is an interaction between $\mathrm{U}$ and $\mathrm{E}$ in determining survival.

The importance and direction of the bias depends on the direction of the U-S and E-S associations (discordant or concordant) and of the $U \times E$ interaction for $S$. Depending on these parameters, the bias can go in any direction: it can distort associations towards the null (e.g., true associations that weaken as age increases), or it can create a false association between $G$ and PD in situations where there is no true association (e.g., no association in younger subjects while there is one in older subjects) or make a true association seem stronger; in some extreme situations, it can even revert the direction of a true association (e.g., true positive association becomes negative as age increases).

MR estimates of the association between $E$ and $P D$ are based on the association between $G$ and $E$, and the association between $\mathrm{G}$ and PD. In one-sample MR, both associations are estimated in the same sample and are likely to be similarly biased; therefore, taking the ratio of these associations cancels out much of the bias. Alternatively, in two-sample MR, only the association between $G$ and $P D$ is estimated in the study sample, and the bias of MR estimates equals the bias seen for the $G$ and PD association (Smit RA et al., Epidemiology 2019;30(6):813-816). 
Supplementary figure 2: MR analyses of the relation of smoking, alcohol, and coffee drinking with PD: (A) Plots relating the effects sizes of the SNP-exposure (Xaxis) and SNP-PD (y-axis, log OR) associations with standard error bars: the slope of the lines corresponds to causal estimates using different methods; (B) funnel plots of individual variant effects plotted against the inverse of their standard error.
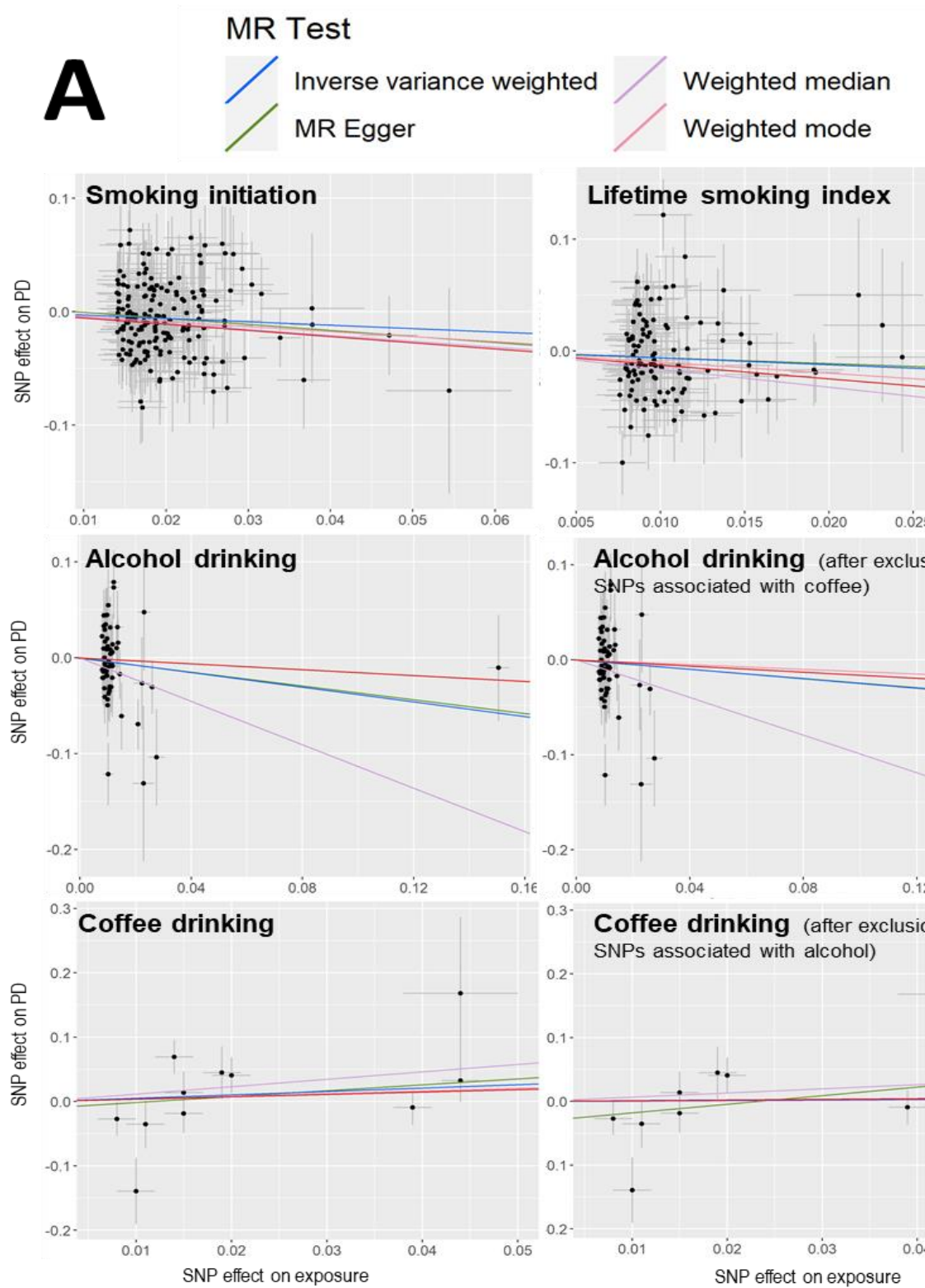

SNP effect on exposure SNPS associated with coffee)

\section{Lifetime smoking index}

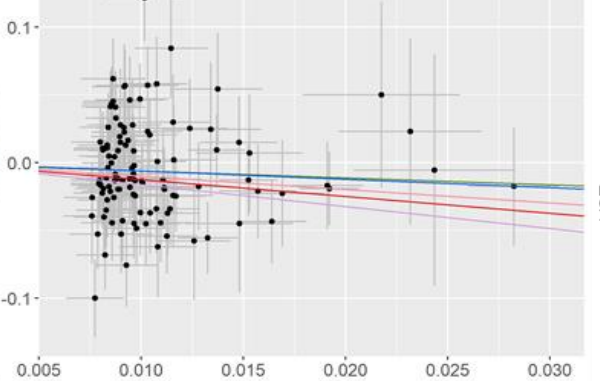

Alcohol drinking (after exclusion of 2

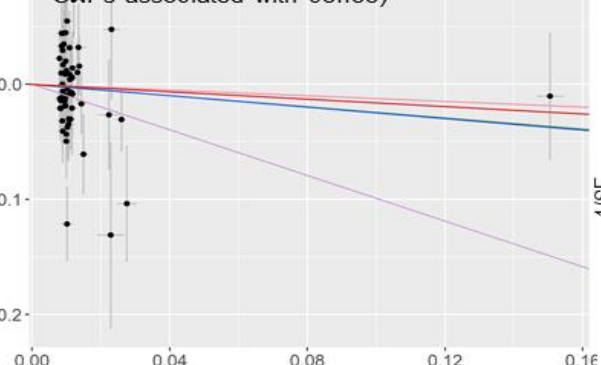

$$
\text { Coffee drinking (after exclusion of } 2
$$
SNPs associated with alcohol)
B

\section{MR Method}
Inverse variance weighted
MR Egger

Weighted median

Weighted mode

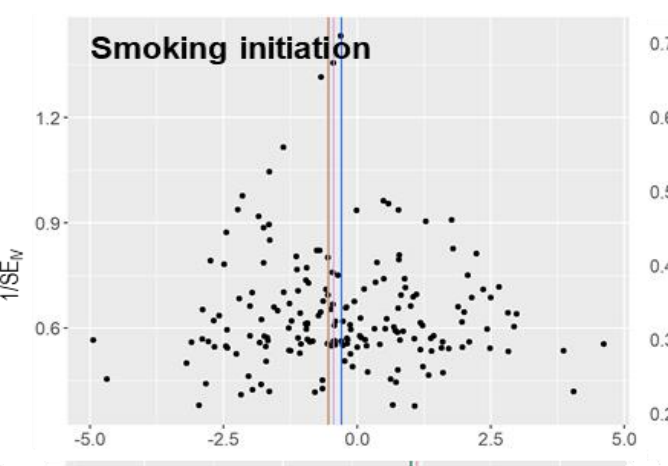

Alcohol drinking
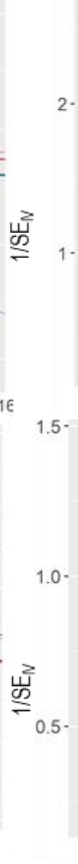

Coffee drinking
Lifetime smoking index

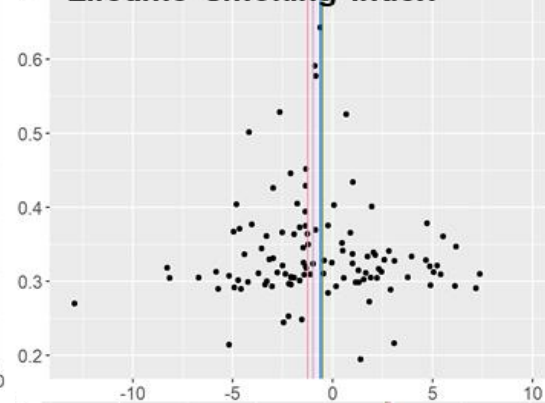

Alcohol drinking (after exclusion of 2 SNPs associated with coffee)
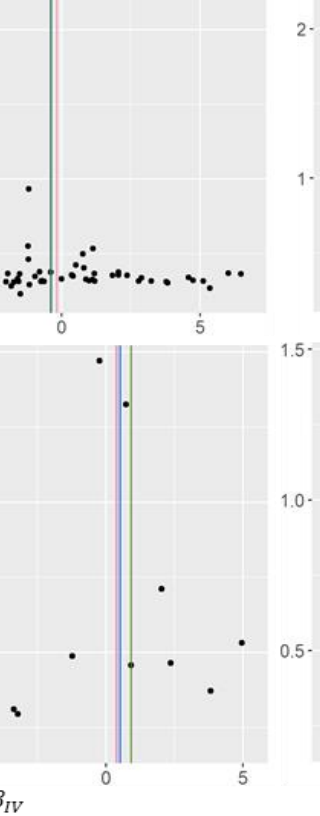

Coffee drinking (after exclusion of 2 SNPs associated with alcohol) 
Supplementary figure 3: Reverse MR analyses of the relation of PD with smoking initiation, lifetime smoking index, and alcohol and coffee drinking: (A) Plots relating the effects sizes of the SNP-PD (x-axis) and SNP-outcomes (smoking, coffee, alcohol; $y$-axis, log OR) associations with standard error bars: the slope of the lines corresponds to causal estimates using different methods; (B) funnel plots of individual variant effects plotted against the inverse of their standard error.
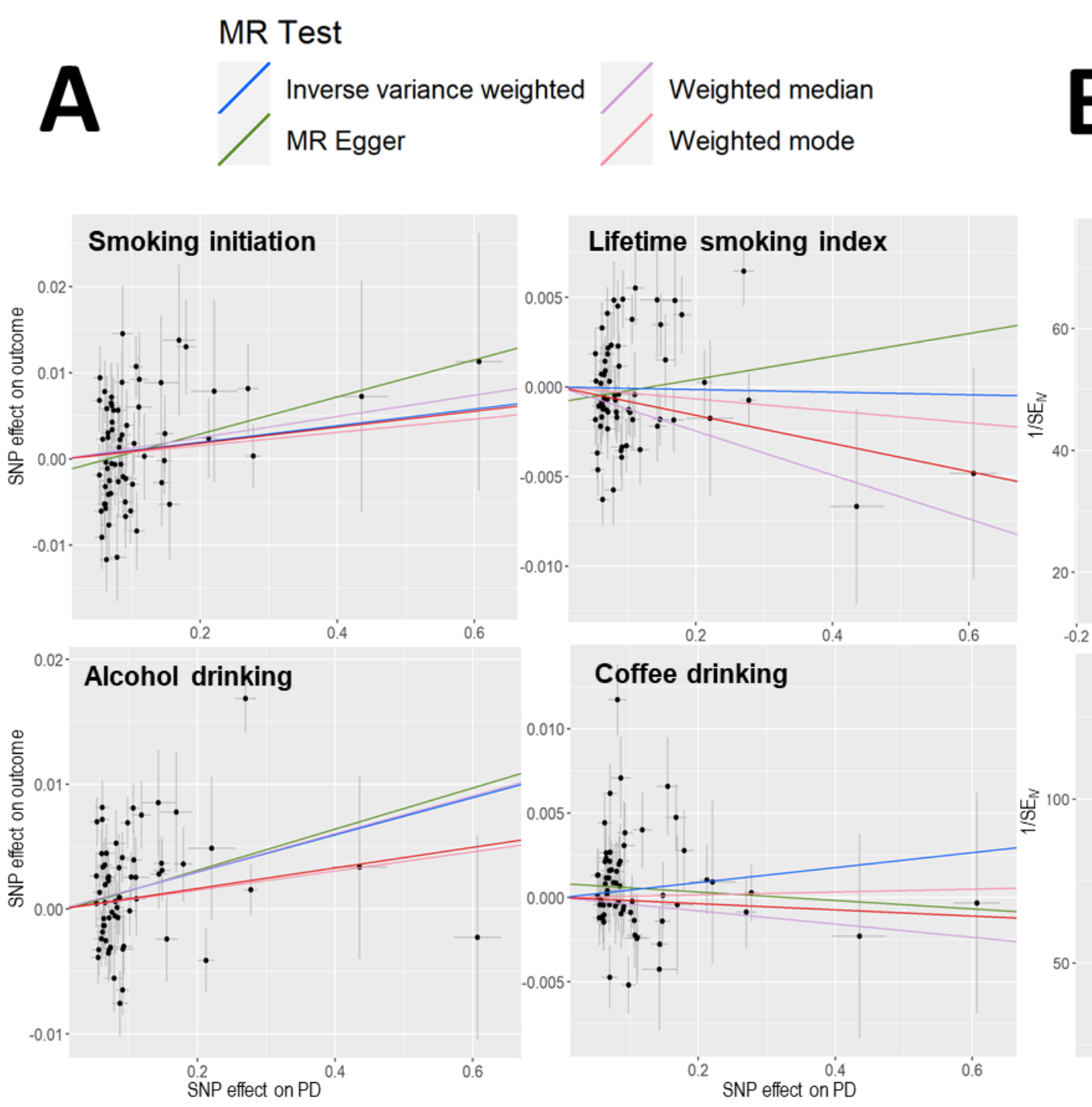
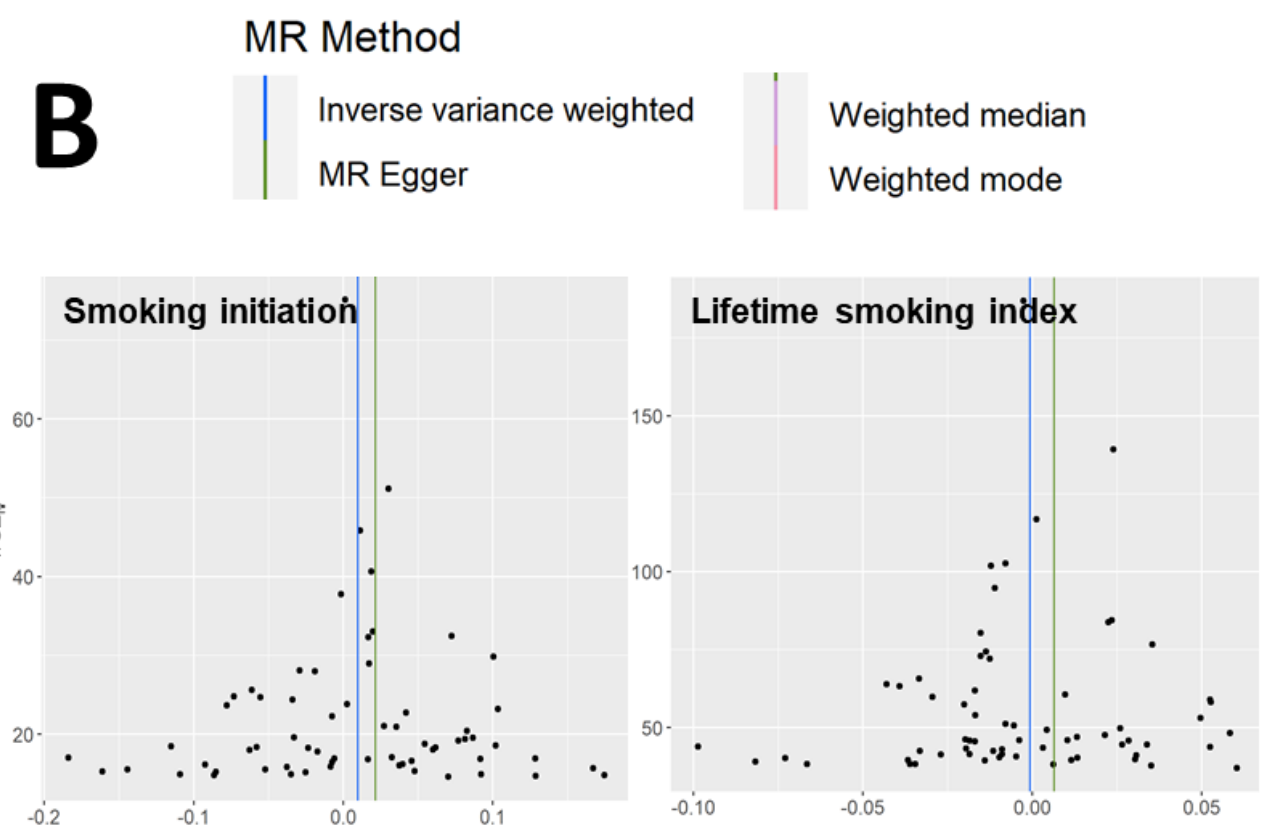

Alcohol drinking

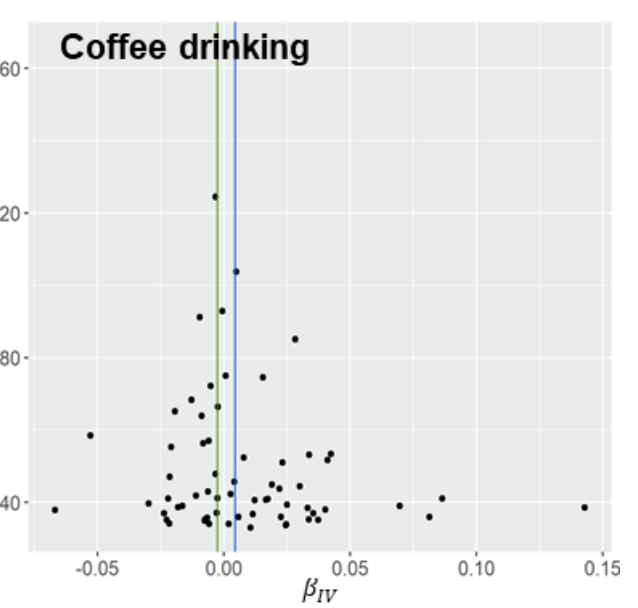

